GA-C24239

\title{
SUPERCRITICAL WATER PARTIAL OXIDATION
}

\section{PHASE I - PILOT-SCALE TESTING I FEASIBILITY STUDIES FINAL REPORT}

\author{
GENERAL ATOMICS \\ P. O. BOX 85608 \\ SAN DIEGO, CA 92186-9784
}

\author{
JANUARY 2005 \\ PREPARED FOR THE UNITED STATES \\ DEPARTMENT OF ENERGY \\ Under Cooperative Agreement \\ No. DE-FC36-00G010529
}




\title{
SUPERCRITICAL WATER PARTIAL OXIDATION
}

\author{
PHASE I - PILOT-SCALE TESTING I FEASIBILITY STUDIES \\ FINAL REPORT
}

\author{
GENERAL ATOMICS \\ P. O. BOX 85608 \\ SAN DIEGO, CA 92186-9784
}

\author{
JANUARY 2005 \\ PREPARED FOR THE UNITED STATES \\ DEPARTMENT OF ENERGY \\ Under Cooperative Agreement \\ No. DE-FC36-00G010529
}


TABLE OF CONTENTS

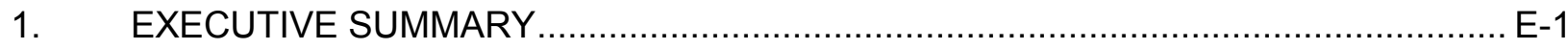

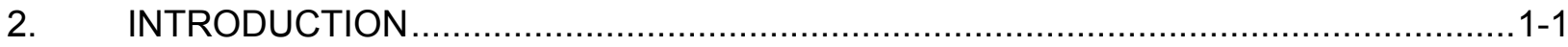

3. TASK 1: PRELIMINARY PILOT-SCALE TESTING .............................................

4. TASK 2: PILOT-SCALE DESIGN \& ANALYSIS .....................................................

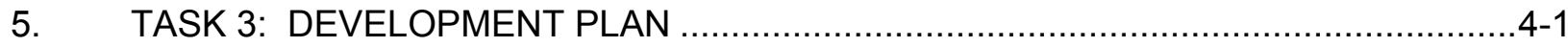

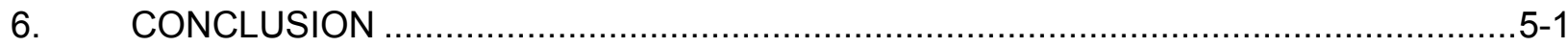

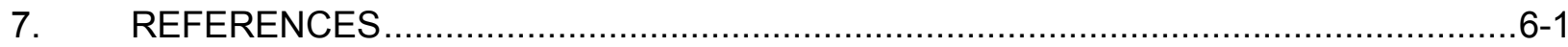

APPENDIX A SWPO BACKGROUND INFORMATION .............................................. A-1

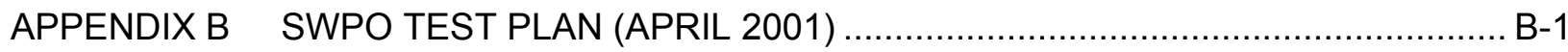

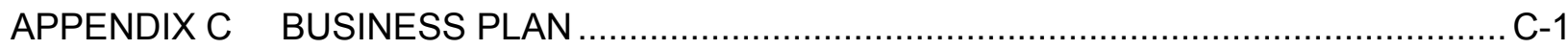

APPENDIX D SURVEY OF MUNICIPAL SEWAGE TREATMENT PLANTS ....................... D-1

\section{LIST OF TABLES}

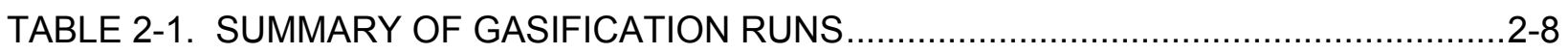

TABLE 2-2. SUMMARY OF 9\% WOOD GASIFICATION RUNS ….................................. $2-14$

TABLE 2-3. COMPARISON OF SWPO GAS PRODUCTION WITH INDIRECTLY

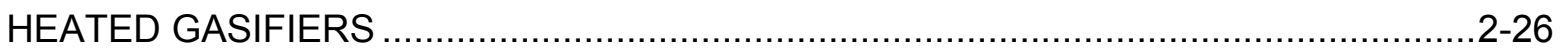

TABLE 2-4. COMPARISON OF SWPO GAS PRODUCTION WITH DIRECTLY

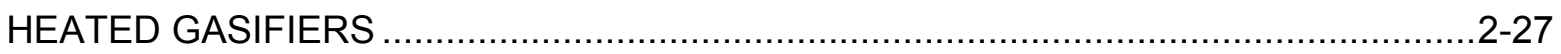

TABLE 2-5. MAXIMUM POSSIBLE GASEOUS HYDROGEN YIELD ................................2-28

TABLE 3-1. SWPO PRODUCTION-SCALE MASS AND ENERGY BALANCE

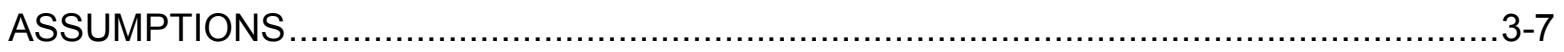

TABLE 3-2. SWPO PRODUCTION-SCALE MASS AND ENERGY BALANCE …....................3-8

TABLE 4-1. TYPICAL COMPOSITION OF SOME BIOMASS MATERIALS ...........................4-4

TABLE 4-2. SWPO ECONOMIC ANALYSIS ASSUMPTIONS ……............................... $4-5$

TABLE 4-3. SWPO CAPITAL COST ESTIMATE FOR COMMERCIAL-SCALE PLANT ..........4-7

TABLE 4-4. INITIAL SWPO OPERATING COST ESTIMATE FOR COMMERCIAL

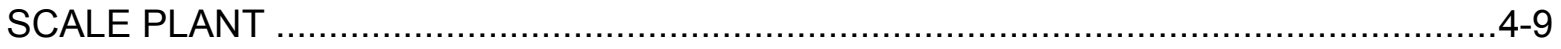

TABLE 4-5. SWPO OPERATING COST ESTIMATE FOR COMMERCIAL SCALE

PLANT FOLLOWING CAPITAL COST RECOVERY .............................................

TABLE A-1. LABORATORY-SCALE SCWG TEST RESULTS ……............................. A-5

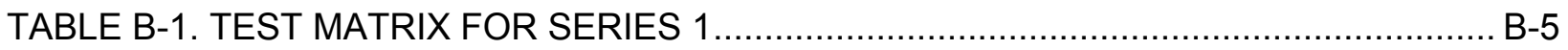

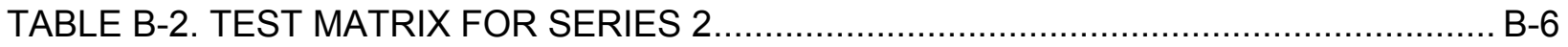




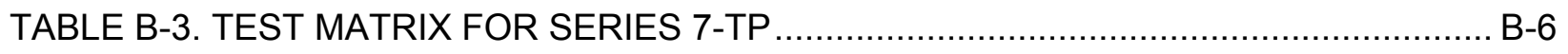

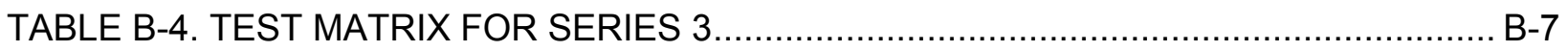

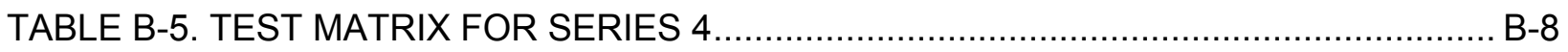

TABLE B-6. TEST MATRIX FOR SERIES 5 ..............................................................

TABLE B-7. TEST MATRIX FOR SERIES 6-TP ............................................................. B-9

TABLE C-1. CITY POPULATION IN THE UNITED STATES …….................................. C-14

TABLE C-2. BUDGETARY ESTIMATE FOR PHASES II THROUGH IV ..............................

\section{LIST OF FIGURES}

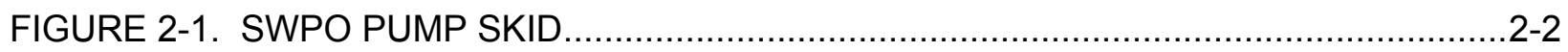

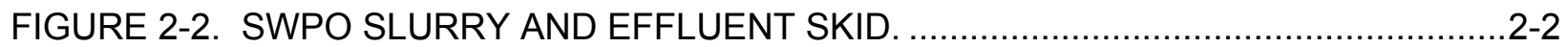

FIGURE 2-3. SWPO REACTOR SKID SHOWING SMALL VESSEL GASIFIER AND

TUBE GASIFIER. 2-3

FIGURE 2-4. SWPO REACTOR SKID WITH SHIELDING AND LARGE VESSEL

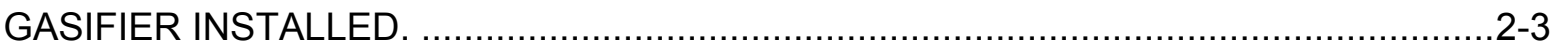

FIGURE 2-5. SWPO LARGE VESSEL GASIFIER. ......................................................... 2-4

FIGURE 2-6. SIMPLIFIED SWPO PROCESS FLOW DIAGRAM.......................................... $2-5$

FIGURE 2-7. GA SWPO PILOT PLANT PROCESS FLOW DIAGRAM (PFD) .......................2-7

FIGURE 2-8. TEMPERATURE AND PRESSURE TRACES FOR SWPO RUN AT $650^{\circ} \mathrm{C} . \ldots 2-16$

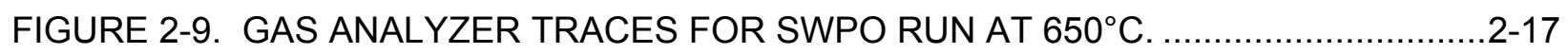

FIGURE 2-10. TEMPERATURE AND PRESSURE TRACES FOR SWPO RUN AT $800^{\circ} \mathrm{C} . ~ .2-18$

FIGURE 2-11. GAS ANALYZER TRACES FOR SWPO RUN AT $800^{\circ} \mathrm{C} \ldots \ldots \ldots \ldots \ldots \ldots \ldots \ldots . . . . . . . . . . . . . . .19$

FIGURE 2-12. COMPARISON OF GA RESULTS AT $650^{\circ} \mathrm{C}$ WITH STANJAN

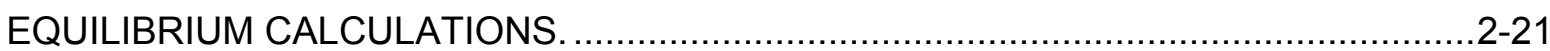

FIGURE 2-13. COMPARISON OF GA RESULTS AT $800^{\circ} \mathrm{C}$ WITH STANJAN

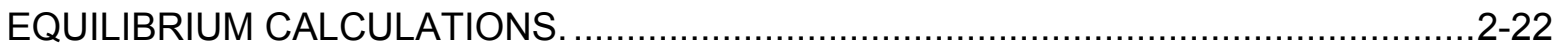

FIGURE 2-14. COMPARISON OF GA AND UHM RESULTS WITH STANJAN

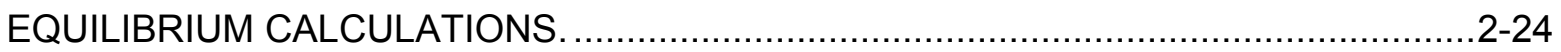

FIGURE 3-1. PROCESS FLOW DIAGRAM FOR SWPO OF SEWAGE SLUDGE WITH

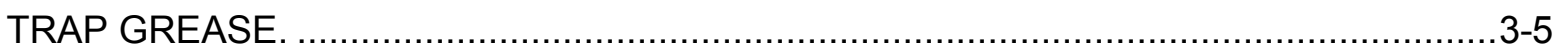

FIGURE 4-1. ENCINA PROCESS SCHEMATIC AND SITE PLAN ….................................4-3

FIGURE 4-2. $\mathrm{H}_{2}$ PRODUCTION COST FOR SWPO OF 12 WT\% SEWAGE SLUDGE

COPROCESSED WITH GREASE AUXILIARY FUEL..............................................4-12 
FIGURE 4-3. $\mathrm{H}_{2}$ PRODUCTION COST FOR SWPO OF 12 WT\% SEWAGE SLUDGE COPROCESSED WITH GREASE AUXILIARY FUEL FOLLOWING CAPITAL COST RECOVERY.

FIGURE 4-4. SWPO REDUCED-SCALE SYSTEM FOR 5 TPD OF SLUDGE SOLIDS COPROCESSED WITH WASTE GREASE.

FIGURE 4-5. ENCINA SLUDGE DEWATERING BUILDING, A POTENTIAL SWPO REDUCEDSCALE DEMONSTRATION SITE

FIGURE 4-6. ENCINA SLUDGE CONVEYOR ROOM IS AVAILABLE FOR A SWPO

REDUCED-SCALE DEMONSTRATION UNIT 4-18

FIGURE C-1. SCHEDULE FOR SWPO DEVELOPMENT AND COMMERCIALIZATION ....... C-5

FIGURE C-2. SCHEDULE FOR SWPO DEVELOPMENT PHASE II. C-9

FIGURE C-3. SCHEDULE FOR SWPO DEVELOPMENT PHASE III. C-11

FIGURE C-4. SCHEDULE FOR SWPO DEVELOPMENT PHASE IV. C-13 


\section{ABBREVIATIONS AND ACRONYMS}

ACS

AIChE

$\mathrm{BCL}$

bdt

Btu

C

$\mathrm{C} 2+$

$\mathrm{CH}_{4}$

$\mathrm{C}_{2} \mathrm{H}_{6}$

$\mathrm{CMC}$

$\mathrm{CO}$

$\mathrm{CO}_{2}$

$\mathrm{CS}$

$\mathrm{Cs}_{2} \mathrm{CO}_{3}$

DOE

$\mathrm{EtOH}$

GA

GC

GJ

gpm

$\mathrm{H}$

$\mathrm{H}_{2}$

$\mathrm{HHV}$

$\mathrm{H}_{2} \mathrm{O}$

ID

IGT

in

L

LCC

LOX

M\&EB

MIT

MM

$\mathrm{MPa}$

MSW

$\mathrm{MTCl}$

MW

$\mathrm{N}_{2}$

$\mathrm{NaCl}$

$\mathrm{Ni}$

$\mathrm{NO}_{x}$

$\mathrm{O}_{2}$

$\mathrm{P}$
American Chemical Society

American Institute of Chemical Engineers

Battelle Columbus Laboratory

Bone dry tons

British thermal unit

Degrees Celsius

Hydrocarbon gases containing 2 or more carbon atoms

Methane

Ethane

Carboxymethylcellulose

Carbon monoxide

Carbon dioxide

Corn starch

Cesium carbonate

Department of Energy

Ethanol

General Atomics

Gas chromatography

Gigajoules

Gallons per minute

Hydrogen

Hydrogen gas

Higher heating value

Water

Inside diameter

Institute of Gas Technology

inch

Liters

Life cycle cost

Liquid oxygen

Mass and energy balance

Massachusetts Institute of Technology

Million

Megapascals

Municipal solid waste

Manufacturing and Technology Conversion International

Megawatts

Nitrogen

Sodium chloride

Nickel

Nitrogen oxides

Oxygen gas

Pressure 


$\begin{array}{ll}\text { PFD } & \text { Process flow diagram } \\ \text { PLC } & \text { Programmable logic controller } \\ \text { POTW } & \text { Publicly owned treatment works } \\ \text { PSA } & \text { Pressure swing adsorption } \\ \text { psi } & \text { pounds per square inch } \\ \text { RAM } & \text { Reliability and maintenance } \\ \text { scfd } & \text { Standard cubic feet per day } \\ \text { scfm } & \text { Standard cubic feet per minute } \\ \text { SCW } & \text { Supercritical water } \\ \text { SCWO } & \text { Supercritical water oxidation } \\ \text { SDSU } & \text { San Diego State University } \\ \text { SO } & \text { Sulfur oxides } \\ \text { SS } & \text { Sewage sludge } \\ \text { SWPO } & \text { Supercritical water partial oxidation } \\ \text { T } & \text { Temperature } \\ \text { TOC } & \text { Total organic carbon } \\ \text { TP } & \text { Time permitting } \\ \text { tpd } & \text { English tons per day } \\ \text { UHM } & \text { University of Hawaii at Manoa } \\ \text { WM } & \text { Wright Malta } \\ \text { wt } & \text { Weight }\end{array}$




\section{EXECUTIVE SUMMARY}

Under Cooperative Agreement No. DE-FC36-00G010529 for the Department of Energy, General Atomics (GA) is developing Supercritical Water Partial Oxidation (SWPO) as a means of producing hydrogen from low-grade biomass and other waste feeds. The Phase I Pilot-scale Testing/Feasibility Studies have been successfully completed and the results of that effort are described in this report.

The key potential advantage of the SWPO process is the use of partial oxidation in-situ to rapidly heat the gasification medium, resulting in less char formation and improved hydrogen yield. Another major advantage is that the high-pressure, high-density aqueous environment is ideal for reacting and gasifying organics of all types. The high water content of the medium encourages formation of hydrogen and hydrogen-rich products and is especially compatible with high water content feeds such as biomass materials. The high water content of the medium is also effective for gasification of hydrogen-poor materials such as coal.

A versatile pilot plant for exploring gasification in supercritical water has been established at GA's facilities in San Diego. The Phase I testing of the SWPO process with wood and ethanol mixtures demonstrated gasification efficiencies of about $90 \%$, comparable to those found in prior laboratory-scale SCW gasification work carried out at the University of Hawaii at Manoa (UHM), as well as other biomass gasification experience with conventional gasifiers. As in the prior work at UHM, a significant amount of the hydrogen found in the gas phase products is derived from the water/steam matrix. The studies at UHM utilized an indirectly heated gasifier with an activated carbon catalyst. In contrast, the GA studies utilized a directly heated gasifier without catalyst, plus a surrogate waste fuel. Attainment of comparable gasification efficiencies without catalysis is an important advancement for the GA process, and opens the way for efficient hydrogen production from low-value, dirty feed materials.

The Phase I results indicate that a practical means to overcome limitations on biomass slurry feed concentration and preheat temperature is to coprocess an auxiliary high heating value material. SWPO coprocessing of two high-water content wastes, partially dewatered sewage sludge and trap grease, yields a scenario for the production of hydrogen at highly competitive prices. It is estimated that there are hundreds if not thousands of potential sites for this technology across the US and worldwide.

The economics for plants processing 40 tpd sewage sludge solids augmented with grease trap waste are favorable over a significant range of cost parameters such as sludge disposal credit and capital financing. Hydrogen production costs for SWPO plants of this size are projected to be about \$3/GJ or less. Economics may be further improved by future developments such as pumping of higher solids content sludges and improved gasifier nozzle designs to reduce char and improve hydrogen yields. The easiest market entry for SWPO is expected to be direct sales to municipal wastewater treatment plants for use with sewage sludge in conjunction with trap grease, as both of these wastes are ubiquitous and have reasonably well-defined negative value (i.e., the process can take credit for reduction of well-defined disposal costs for these 
streams). Additionally, waste grease is frequently recovered at municipal wastewater treatment plants where it is already contaminated with sewage.

SWPO should also be favorable to other market applications in which low or negative value, high water content biomass is available in conjunction with a low or negative value fuel material. For biomass slurries primary candidates are sewage sludge, manure sludge, and shredded and/or composted organic municipal solid waste (MSW) slurries. For the high heating value stream primary candidates are trap grease, waste plastic or rubber slurries, and coal or coke slurries.

Phase II of the SWPO program will be focused on verifying process improvements identified during Phase I, and then performing extended duration testing with the GA pilot plant. Tests of at least 100 hours duration using sewage sludge and trap grease as simultaneous feedstocks are a primary objective. Follow-on Phases III and IV of the SWPO program will develop and demonstrate a dedicated 5 tpd reduced-scale SWPO facility at a location such as the Encina municipal wastewater treatment plant. Subsequent to this demonstration, the technology will be ready for a commercial-scale demonstration.

While there are clearly technical challenges that must still be addressed, SWPO represents an outstanding opportunity to further the dual goals of developing a hydrogen economy and practicing environmentally friendly waste disposal. It may well represent one of the few scenarios in which hydrogen may be produced economically from biomass at a relatively small scale. SWPO could thus play a pivotal role in the proliferation of distributed hydrogen generation. 


\section{INTRODUCTION}

Under Cooperative Agreement No. DE-FC36-00G010529 for the Department of Energy, General Atomics (GA) is developing Supercritical Water Partial Oxidation (SWPO) for efficient and environmentally attractive gasification and hydrogen production from low-grade biomass materials. In particular biomass materials such as thickened sewage sludge solids, grease trap waste and sorted municipal solid waste (MSW), as well as low-grade fossil fuels such as highsulfur coal and petroleum coke, are targeted for distributed generation of hydrogen close to population centers.

SWPO involves carrying out oxidative reactions in the supercritical water (SCW) environment akin to high-pressure steam - in the presence of sub-stoichiometric quantities of oxidant, typically pure oxygen or air. A key advantage anticipated for the SWPO process is the use of partial oxidation in-situ to rapidly heat the gasification medium, resulting in less char formation and improved hydrogen yield. Another major advantage of SWPO is that the high-pressure, high-density aqueous environment is ideal for reacting and gasifying organics. The high water content of the SWPO medium encourages formation of hydrogen and hydrogen-rich products and is very compatible with high water content feeds such as biomass materials. By the same token, the high water content of the SWPO medium is effective for gasification of hydrogen-poor materials such as coal. Further background information on the SWPO process may be found in Appendix A.

The overall goals and objectives of the SWPO development program are to develop and commercialize a technology to convert biomass, waste materials such as treated or untreated sewage sludge solids, sorted MSW such as plastics and rubber, and low grade fossil fuels such as petroleum coke and high-sulfur coal to hydrogen. The emphasis of the development program is to focus on low- and negative-value municipal wastes that are currently costly and troublesome to dispose of. In particular, sewage sludge solids (SSS) are targeted as a primary feedstock for SWPO to offset the current high cost of disposal. Many municipalities pay over $\$ 200$ per dry ton for disposal of treated SSS, also referred to as biosolids. The SWPO program is targeting primary and secondary sewage sludge solids, before final treatment and disposal as biosolids, with operational cost savings in addition to avoided disposal costs. This cost-savings incentive is an important factor in achieving competitive hydrogen production costs using SWPO.

SWPO is ideally suited for processing wet biomass wastes such as SSS. Unlike other gasification technologies, feedstocks do not have to be dried before feeding to SWPO. Thus, pretreatment costs can be minimized for wet biomass feeds. Many wet biomass feeds cannot be slurried and pumped at concentrations much above about $12 \mathrm{wt} \%$ dry solids. To overcome this limitation, a higher heating value fuel such as waste grease must be co-fed to SWPO along with the wet biomass in order to achieve desired gasification temperatures and hydrogen yields. Other example candidate waste fuels for co-feeding with wet biomass feeds are slurried plastics and rubber, which can be acquired as sorted MSW, and slurried coal or petroleum coke. 
A multiphase SWPO development program is planned to perform feasibility studies, pilot-scale tests, system integration and reduced-scale demonstration at a selected wastewater treatment facility, and finally commercial-scale SWPO. This 9 year development program is nearing the end of its third year with the completion of this Phase I final report. For Phase I the tasks performed and reported on herein are as follows:

Task 1: Pilot-Scale Preliminary Testing

- Perform SWPO testing on biomass fuels and coal.

Task 2: Pilot-scale Design and Analysis

- Perform pilot-scale conceptual design of SWPO system for Phase II development.

- Perform system engineering evaluation to predict when and how hydrogen production goals can be met.

Task 3: Development Plan

- Prepare a SWPO development plan, including cost and schedule estimate.

- Prepare a business plan to identify SWPO market potential.

- Define follow-on activities from preliminary testing through pilot-scale demonstration of an integrated SWPO system.

This report presents the results of the Phase I work. Section 3 describes the Phase I testing, Section 4 presents the pilot-scale design and analysis, and Section 5 presents the development plan, including a description of the Phase II through Phase IV follow-on efforts. Finally, Section 6 presents the Phase I conclusions. 


\section{TASK 1: PRELIMINARY PILOT-SCALE TESTING}

SWPO tests were performed to explore the use of partial oxidation in-situ to rapidly heat the gasification medium in order to reduce char formation and improve hydrogen yields. A test plan was prepared at the start of testing in April, 2001. This document is included as Appendix B, although the experimental matrix evolved considerably from the original plan.

\subsection{TEST DESCRIPTION}

The testing was performed using GA's pilot plant, shown in Figures 2-1 through 2-5. Figure 2-1 shows the liquid pumping skid, while Figure 2 shows the slurry pumping skid.

A number of different gasifier configurations were tested over the course of the Phase I effort. Figure 2-3 shows two of the gasifiers used during earlier testing, the "small" downflow vessel gasifier (labeled "small vessel reactor" in Figure 2-3, volume about 4 liters), and the horizontal tube gasifier (labeled "tube reactor" in Figure 2-3, volume about 9 liters). The bulk of the testing was carried out with the "large" downflow vessel gasifier, shown in Figures 2-4 and 2-5. The gasifier reactor is covered by insulation, although the gasifier top head is visible above the insulation. This gasifier has a volume of about 10 liters, and at the flow rates tested provides a gas residence time of about 75 seconds at $650^{\circ} \mathrm{C}$ operating temperature and about 60 seconds at $800^{\circ} \mathrm{C}$ operating temperature. Solids (feed particulates, ash and char) can potentially have a much lower residence time by falling at terminal velocity through the vessel, and most tests incorporated one or more screens or baffles to prevent such gasifier short circuiting.

Figure 2-6 provides a simplified SWPO process flow diagram illustrating the primary process features. In this figure, the "SWPO reactor" is the gasifier. 


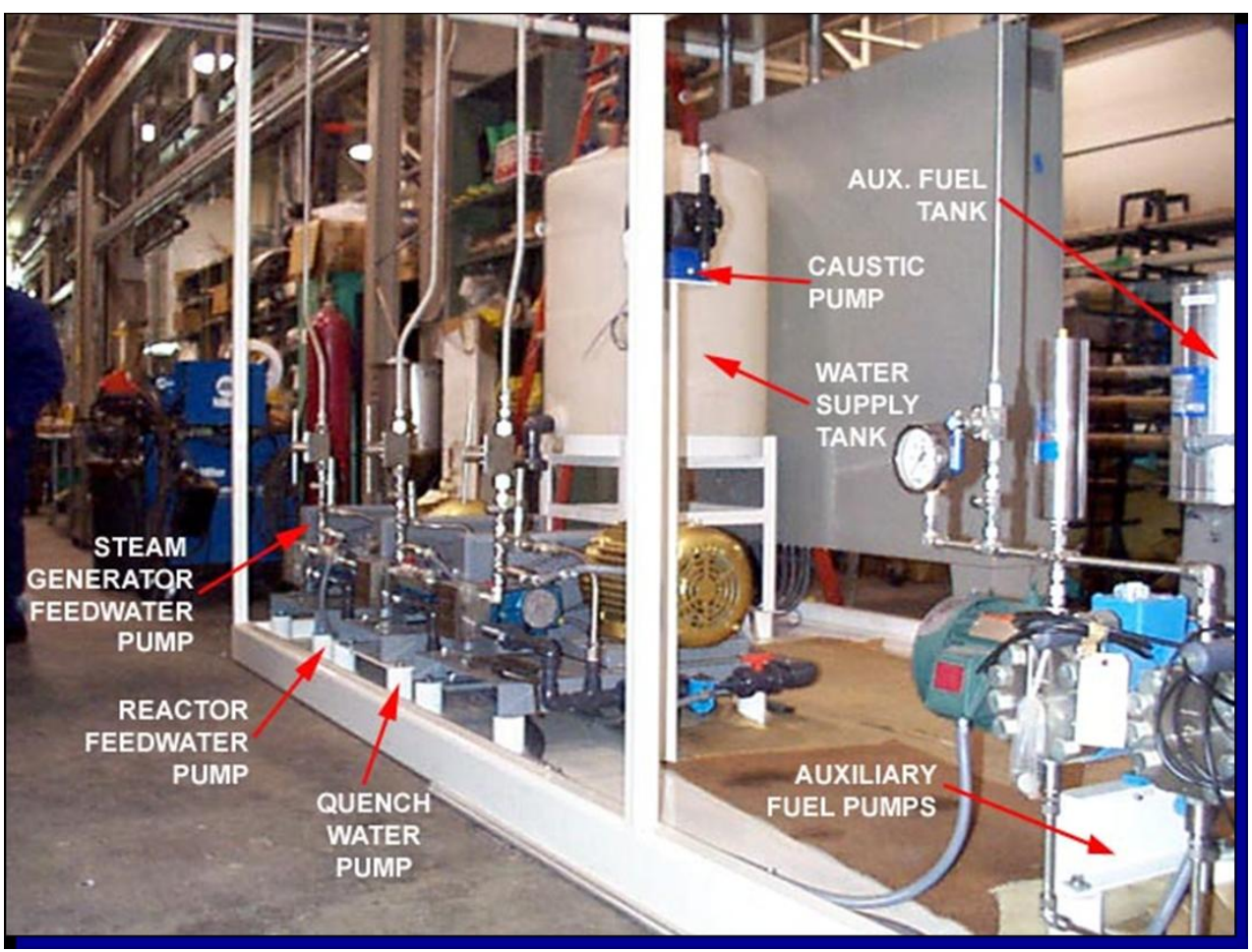

Figure 2-1. SWPO pump skid

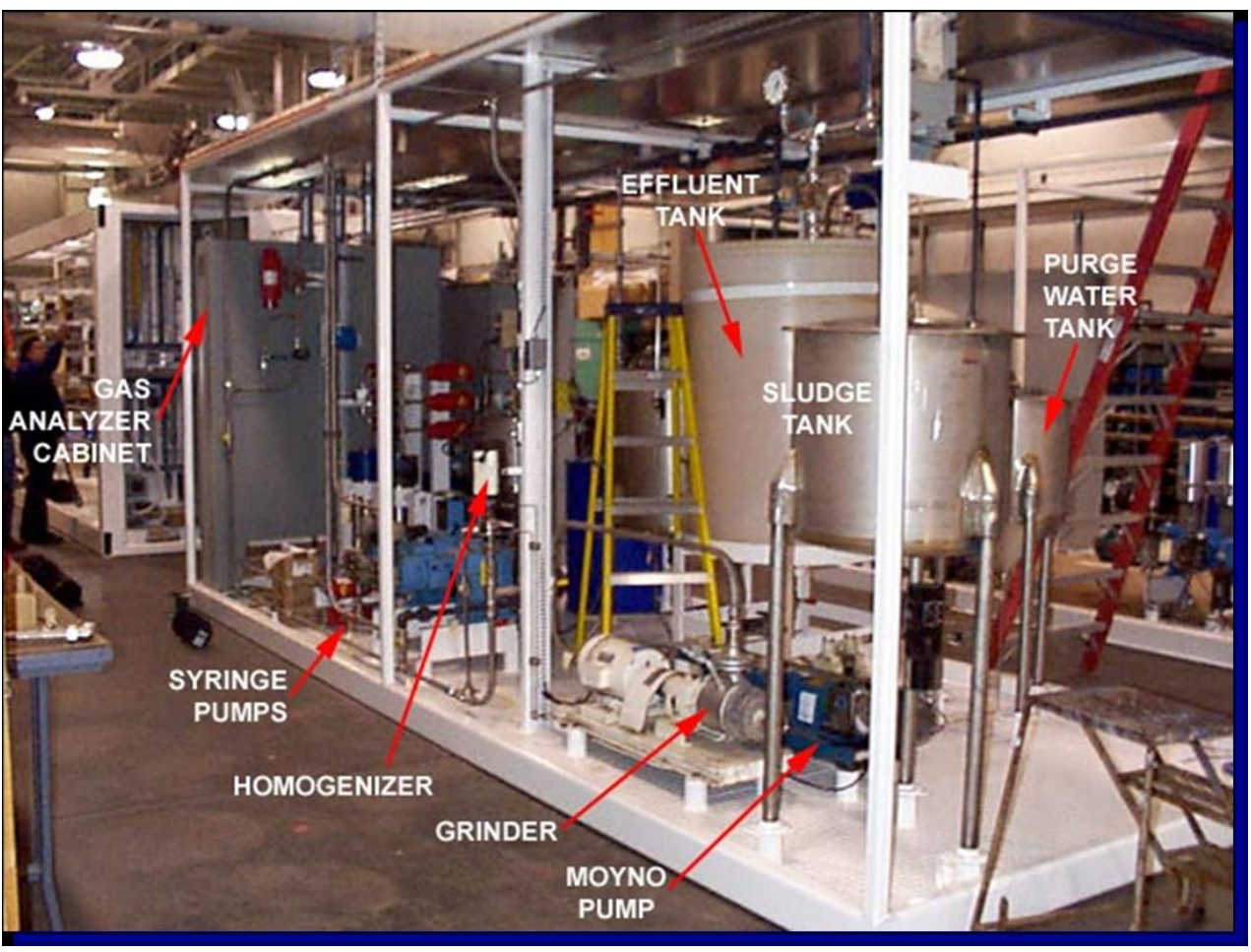

Figure 2-2. SWPO slurry and effluent skid. 


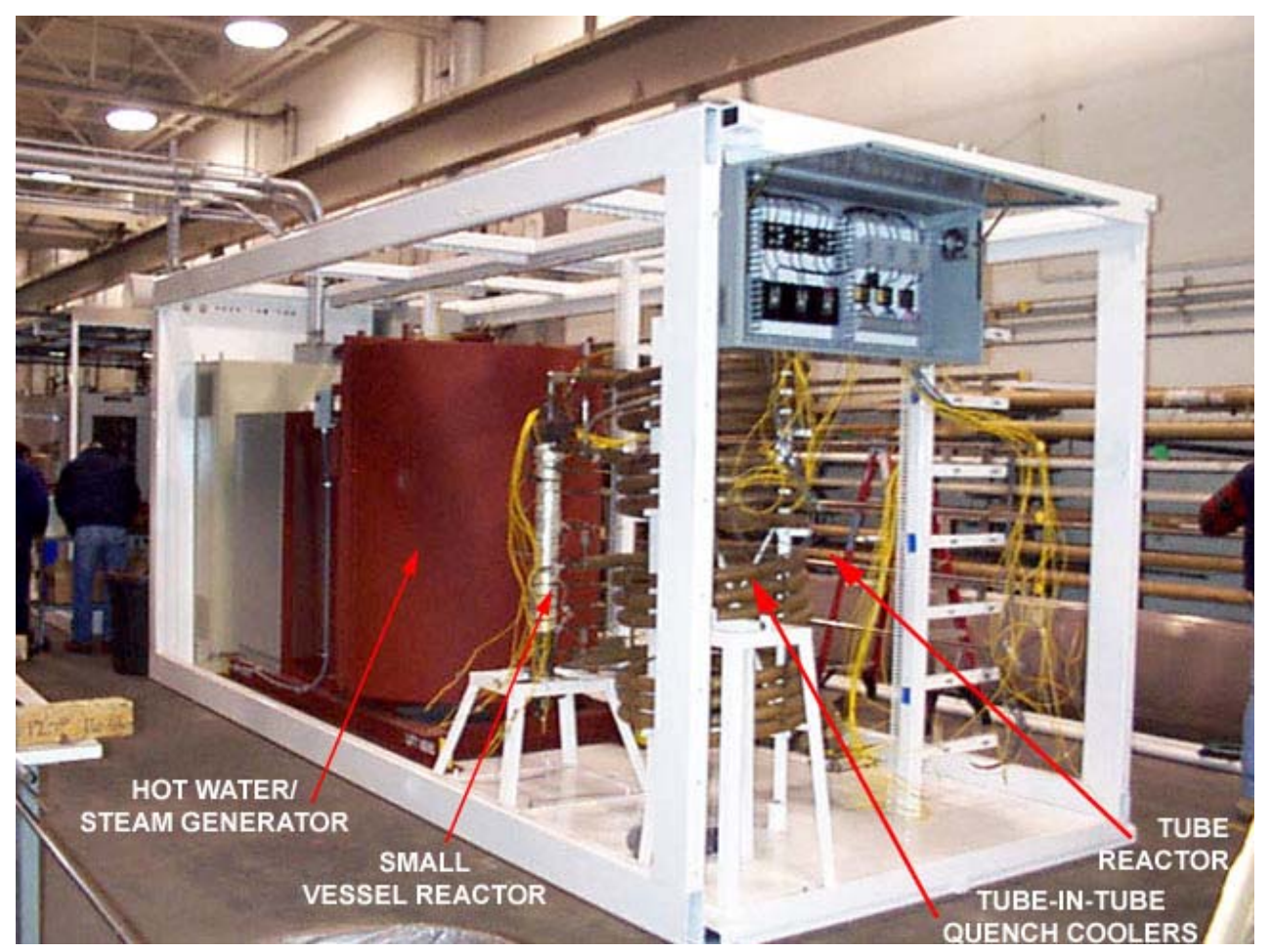

Figure 2-3. SWPO reactor skid showing small vessel gasifier and tube gasifier.

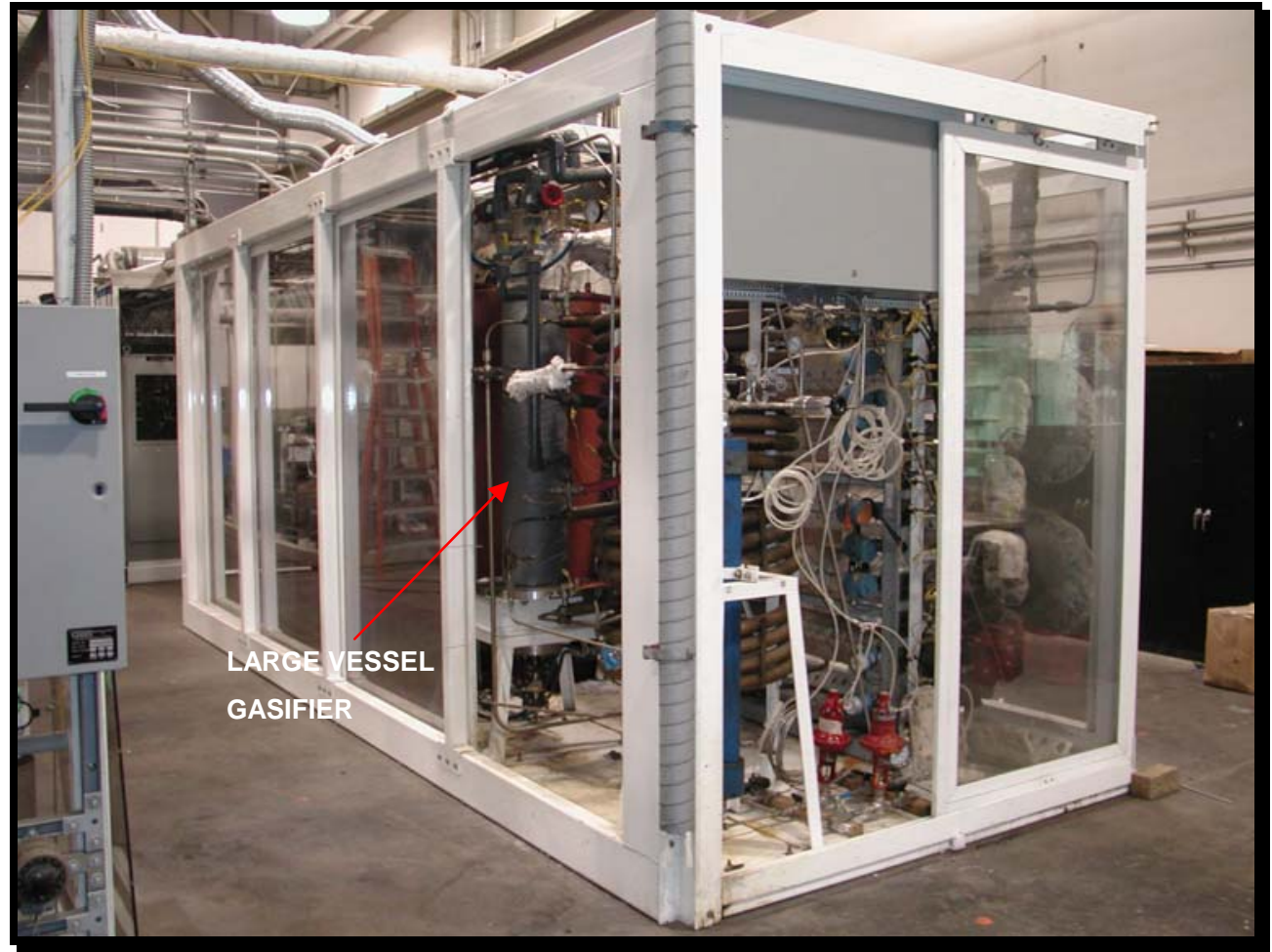

Figure 2-4. SWPO reactor skid with shielding and large vessel gasifier installed. 


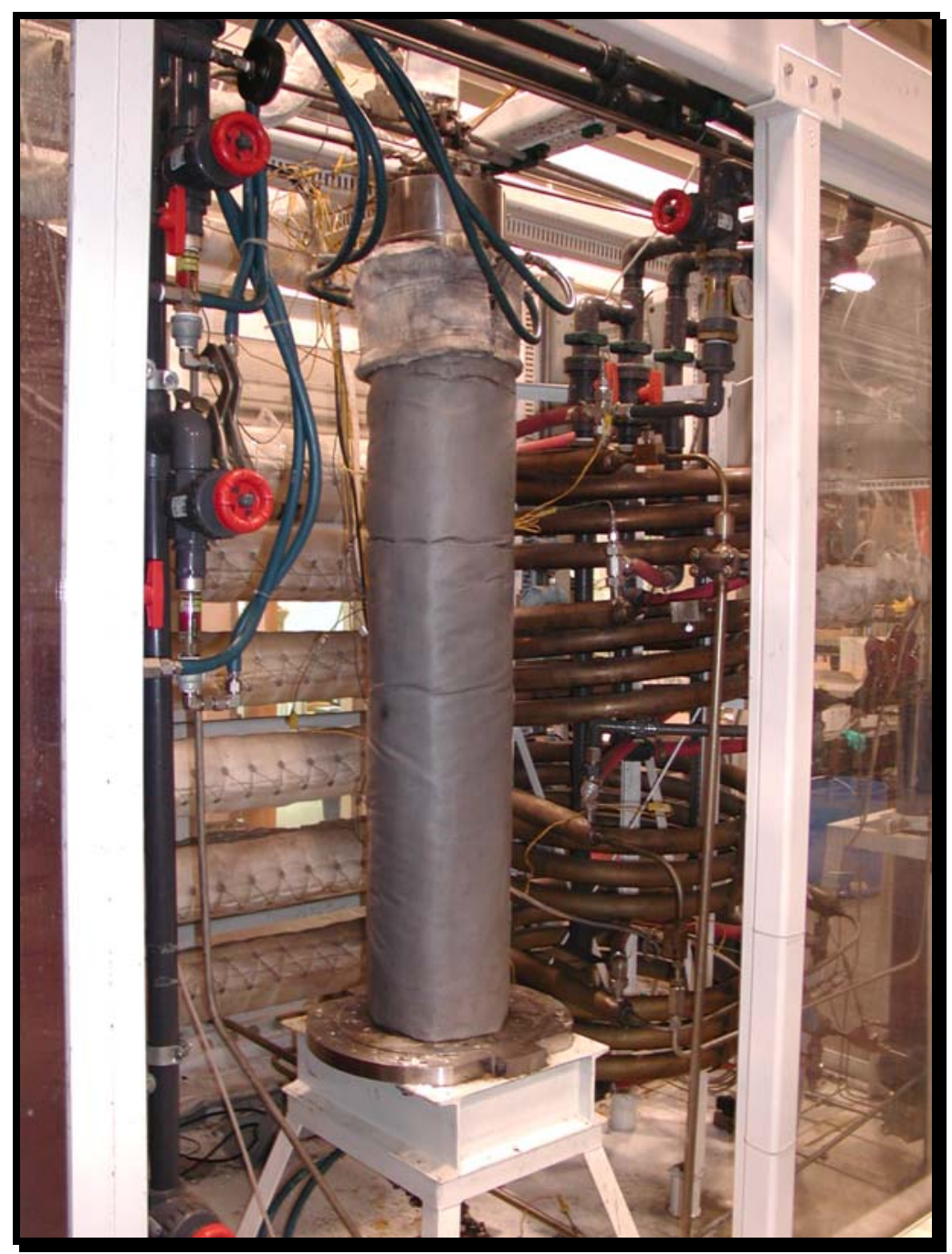

Figure 2-5. SWPO large vessel gasifier. 


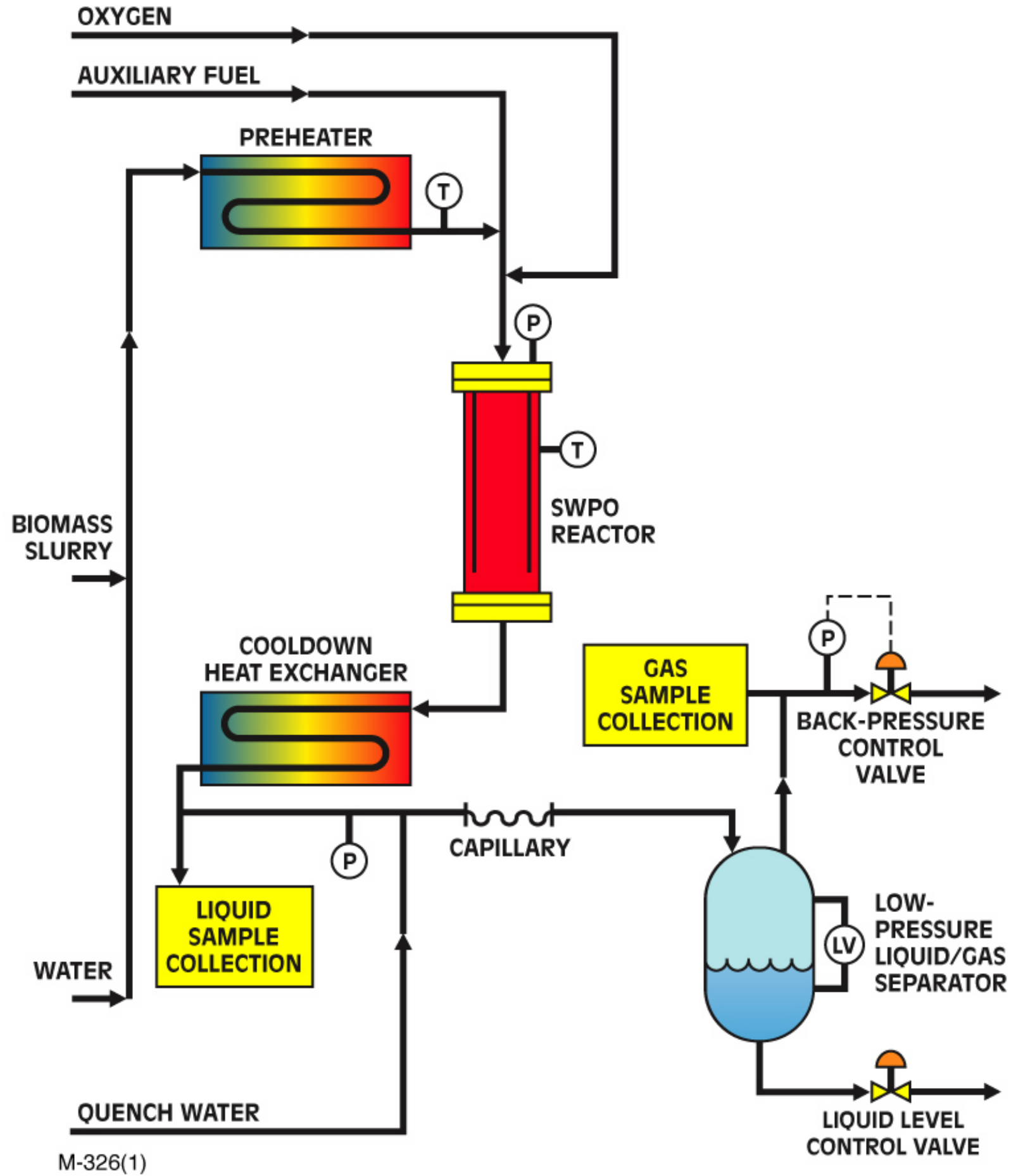

07-30-02

Figure 2-6. Simplified SWPO process flow diagram. 
Figure 2-7 provides a more detailed SWPO process flow diagram (PFD) for the gasification tests carried out with the large vessel gasifier. Dual syringe pumps are used to deliver high pressure slurry to the system. Pressurized slurry is fed to the preheater where it is preheated to a temperature of about $250^{\circ} \mathrm{C}$. An auxiliary fuel is also necessary to help attain the desired gasifier operating temperature. Ethanol was used as the auxiliary fuel during Phase I. In actual practice, this auxiliary fuel would be a co-feed of high heating value waste such as trap grease or slurried plastic, rubber, or coal. As shown in Figures 2-6 and 2-7, high-pressure auxiliary fuel (ethanol) and oxygen are combined with the preheated slurry at the gasifier inlet. Dependent upon the quantity of oxygen provided, oxidation of a portion of the organic feeds results in a nominal gasifier temperature of $650-800^{\circ} \mathrm{C}$. In the gasifier, the organic feed is converted primarily to $\mathrm{CO}_{2}, \mathrm{H}_{2} \mathrm{O}, \mathrm{H}_{2}, \mathrm{CH}_{4}$ and $\mathrm{CO}$.

The gasifier effluent is cooled to near ambient temperature by a series of annular heat exchangers. Pressure control water is introduced and the stream passes through a capillary to be depressurized to slightly above atmospheric pressure. The flow of the pressure control water is varied to maintain the gasifier at the desired pressure of 3400 psi. Following depressurization, the effluent is phase separated in a low pressure gas-liquid separator. Level control in the phase separator is aided by the introduction of a low flow of air from an air cylinder. Liquid effluent $\mathrm{pH}$ and conductivity are measured on-line in the effluent line. The liquid effluent is then collected in a tank, while the gases are vented through the facility carbon filter and released to the atmosphere. Liquid effluent samples are collected either just downstream of the cooldown heat exchanger or from the drain line of the effluent collection tank. The effluent gas is monitored online upstream of the carbon filters for $\mathrm{CO}_{2}, \mathrm{H}_{2}, \mathrm{CH}_{4}, \mathrm{CO}$, and $\mathrm{O}_{2}$ content.

Table 2-1 provides a synopsis of the Phase I pilot-scale testing carried out. All tests were carried out at 3400 psi. As previously mentioned, 3 different gasifiers were used in the course of the testing. As shown in Table 2-1, several runs with a composted mixture of municipal solid waste (MSW) and SSS were carried out with a tube gasifier in the absence of oxidant, i.e., they were indirectly heated and did not utilize partial oxidation. The tube gasifier had an ID of 0.815 in. and a length of about 90 feet. The composted MSW/SSS was a product of the Bedminster composting process. In the large downflow vessel tests, a "J-screen" was frequently utilized to help increase the residence time of solid particles. A J-screen is essentially a rugged filter plate or grate made from two layers of bars at right angles to one another. The J-screens helped retain larger particles in the gasifier while allowing the process fluid and smaller particles to pass through. 
GA-C24239

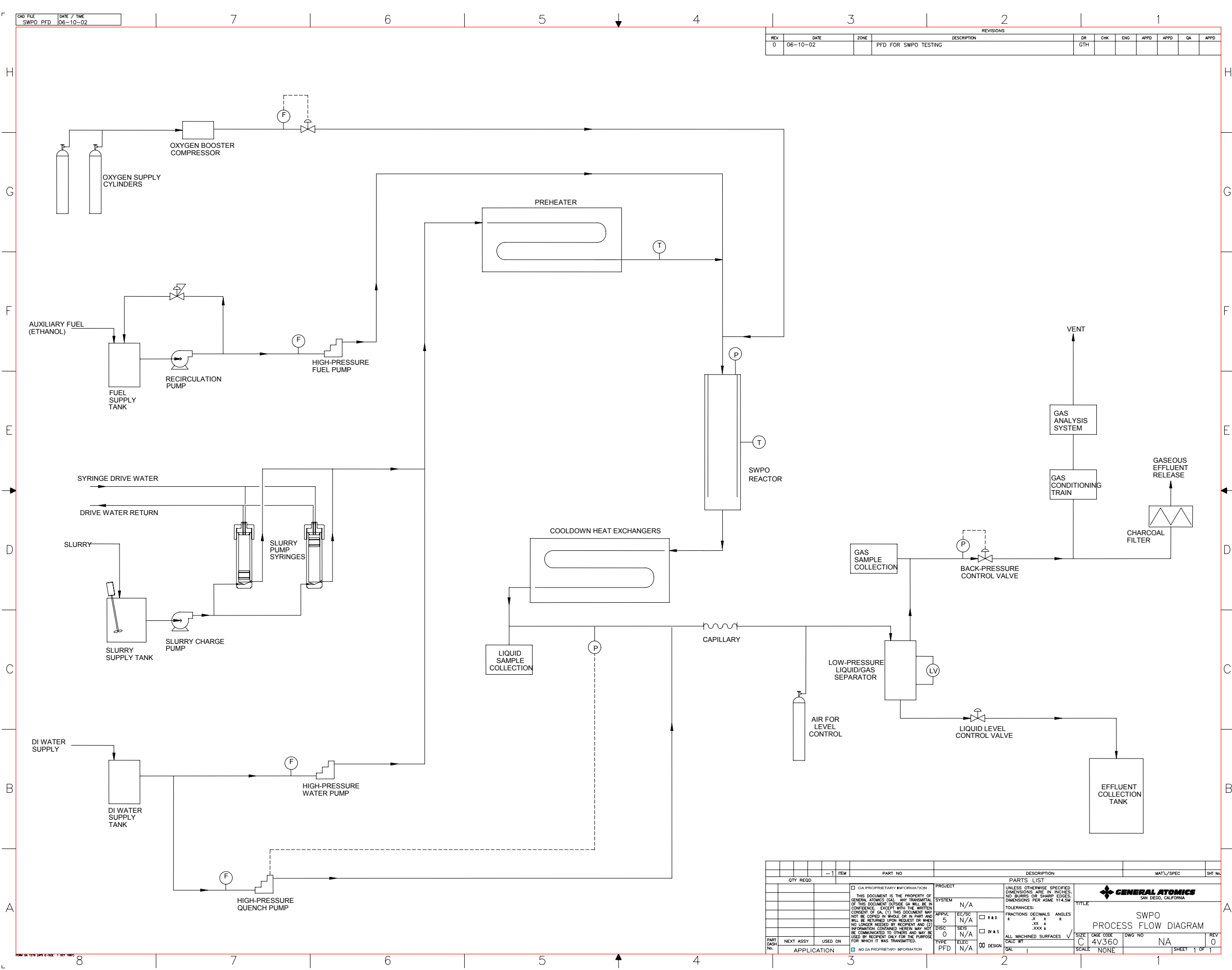

Figure 2-7. GA SWPO pilot plant process flow diagram (PFD).

$2-7$ 
TABLE 2-1. SUMMARY OF GASIFICATION RUNS

\begin{tabular}{|c|c|c|c|c|c|}
\hline Feed & Run Dates & Gasifier Type & System Configuration & Run Conditions & Results \\
\hline $40 \%$ corn starch & $6 / 19 / 01$ & $\begin{array}{l}\text { Small vessel } \\
\text { (volume } \sim 4 \mathrm{~L} \text { ) }\end{array}$ & $\begin{array}{l}\text { Mixing tee - premix feed and } \\
\text { SCW to rapidly heat feed. }\end{array}$ & $605^{\circ} \mathrm{C}$ & $\begin{array}{l}\text { Significant char formation, insufficient gasification } \\
\text { temperature. }\end{array}$ \\
\hline $40 \%$ coal & $6 / 28 / 01 ; 7 / 2 / 01$ & Small vessel & $\begin{array}{l}\text { Mixing tee - premix feed and } \\
\text { SCW to rapidly heat feed. }\end{array}$ & $530^{\circ} \mathrm{C} ; 620^{\circ} \mathrm{C}$ & $\begin{array}{l}\text { Insufficient temperature and solids residence time } \\
\text { resulting in poor gasification of coal. }\end{array}$ \\
\hline $\begin{array}{l}30-40 \% \text { MSW/SS } \\
\text { compost }\end{array}$ & $8 / 16 / 01$ & Small vessel & $\begin{array}{l}\text { Mixing tee - premix feed and } \\
\text { SCW to rapidly heat feed. }\end{array}$ & $570^{\circ} \mathrm{C}$ & $\begin{array}{l}\text { Too much supercritical dilution water at too low a } \\
\text { temperature and oxidation of nearly all the feed, } \\
\text { resulting in low gasification temperatures and poor } \\
\text { gasification yields. }\end{array}$ \\
\hline $\begin{array}{l}30-40 \% \text { MSW/SS } \\
\text { compost }\end{array}$ & $\begin{array}{c}\text { 10/12/01; 10/31/01; } \\
11 / 8 / 01 ; 11 / 19 / 01 ; 1 / 3 / 02\end{array}$ & $\begin{array}{c}\text { Pipe } \\
\text { (volume } \sim 9 \mathrm{~L})\end{array}$ & Pipe preheater, no oxidant & $620^{\circ} \mathrm{C}-650^{\circ} \mathrm{C}$ & Preheat $\mathrm{T}<400^{\circ} \mathrm{C}$ necessary to avoid charring \\
\hline $30 \%$ corn starch & $1 / 30 / 02$ & Pipe & Pipe preheater, air oxidant & $650^{\circ} \mathrm{C}, 300^{\circ} \mathrm{C}$ preheat & Preheat $\mathrm{T}<300^{\circ} \mathrm{C}$ necessary to avoid charring \\
\hline $\begin{array}{l}10 \% \text { wood }+10 \% \\
\text { coal }+ \text { ethanol } \\
(\mathrm{EtOH})\end{array}$ & $3 / 18 / 02 ; 3 / 21 / 02$ & $\begin{array}{l}\text { Large vessel } \\
\text { (volume } \sim 10 \mathrm{~L} \text { ) }\end{array}$ & $\begin{array}{l}\text { Gasifier baffle; gasifier mid- } \\
\text { screen }\end{array}$ & $800^{\circ} \mathrm{C}, 250^{\circ} \mathrm{C}$ preheat & $\begin{array}{l}\text { Poor mixing and insufficient solids residence time } \\
\text { resulting in poor gasification of coal and rapid buildup } \\
\text { of char }\end{array}$ \\
\hline $10 \%$ wood + EtOH & $4 / 10 / 02$ & Large vessel & $\begin{array}{l}\mathrm{J} \text {-screens at gasifier middle and } \\
\text { bottom }\end{array}$ & $650^{\circ} \mathrm{C}, 250^{\circ} \mathrm{C}$ preheat & Successful run. Good hydrogen yield. \\
\hline $10 \%$ wood $+\mathrm{EtOH}$ & $4 / 12 / 02$ & Large vessel & J-screen at gasifier bottom & $650^{\circ} \mathrm{C}, 250^{\circ} \mathrm{C}$ preheat & Successful run. Good hydrogen yield. \\
\hline $10 \%$ wood $+\mathrm{EtOH}$ & $4 / 17 / 02$ & Large vessel & $\mathrm{J}$-screen at gasifier bottom & $800^{\circ} \mathrm{C}, 250^{\circ} \mathrm{C}$ preheat & Successful run. Good hydrogen yield. \\
\hline $10 \%$ wood + EtOH & $4 / 18 / 02$ & Large vessel & No J-screens & $800^{\circ} \mathrm{C}, 250^{\circ} \mathrm{C}$ preheat & Successful run. Good hydrogen yield. \\
\hline $10 \%$ wood $+\mathrm{EtOH}$ & $4 / 23 / 02$ & Large vessel & No J-screens & $650^{\circ} \mathrm{C}, 250^{\circ} \mathrm{C}$ preheat & Successful run. Good hydrogen yield. \\
\hline $10 \%$ wood $+\mathrm{EtOH}$ & $4 / 24 / 02$ & Large vessel & No J-screens & $800^{\circ} \mathrm{C}, 250^{\circ} \mathrm{C}$ preheat & Successful run. Good hydrogen yield. \\
\hline $\begin{array}{l}10 \% \text { corn starch }+ \\
\text { EtOH }\end{array}$ & $\begin{array}{l}4 / 25 / 02 ; 4 / 26 / 02 ; 4 / 30 / 02 \\
5 / 3 / 02\end{array}$ & Large vessel & Various J-screen positions & $650^{\circ} \mathrm{C}$ & $\begin{array}{l}\text { Corn starch can only be preheated to } 70^{\circ} \mathrm{C} \text { to avoid } \\
\text { thickening and preheater plugging. }\end{array}$ \\
\hline $\begin{array}{l}\text { High solids feeds } \\
\text { (40\% corn starch, } \\
15 \% \text { wood, } 20 \% \\
\text { MSW/SSS compost) } \\
\text { + EtOH }\end{array}$ & $\begin{array}{c}5 / 8 / 02 ; 5 / 14 / 02 \\
5 / 15 / 02 ; 5 / 16 / 02,5 / 17 / 02\end{array}$ & Large vessel & $\mathrm{J}$-screen at gasifier bottom & $650^{\circ} \mathrm{C}$ & $\begin{array}{l}40 \% \text { corn starch plugs preheater even at } 70^{\circ} \mathrm{C} \text {. First } \\
\text { use of new suspending agent (commercial gum) } \\
\text { leads to pumping problems with } 15 \% \text { wood. Poor } \\
\text { nozzle dispersion leads to char buildup and plugging } \\
\text { at gasifier bottom with MSW/SSS compost. }\end{array}$ \\
\hline
\end{tabular}


The tests listed in Table 2-1 summarize the chronological progress that was made during Phase I. A number of problems or limitations were encountered and overcome in the course of testing, culminating in a series of wood flour plus ethanol co-feed gasification runs with good hydrogen yields. Finally, additional tests were performed with corn starch (as a reference material), wood and MSW/SSS in attempting to increase the solids content of the biomass feeds, but without much success. The following section provides further discussion of the Phase I tests in Table 2-1 and their impact on the technology development.

\subsection{TEST RESULTS AND DISCUSSION}

\section{Slurry Pumping}

Reliable high-pressure pumping of heavy biomass slurries is an essential requirement of the SWPO process. In the dual syringe pump developed by GA under other programs, clean water is pumped to the top side of a piston located within a cylindrical vessel, forcing the slurry below the piston into the SWPO system. When the cylinder is depleted of slurry, it is switched offline and refilled using a low pressure pump. Meanwhile, a second cylinder is providing feed to the system, allowing for continuous feed flow. The continuous slurry delivery is facilitated by computer sequenced ball valves. The dual syringe pump has an advantage over a typical reciprocating pump because the valves are only cycled about once every 5 minutes, rather than once a second for the check valves in reciprocating pumps, thus minimizing valve wear and fouling. In addition, powered actuation of these ball valves provides better assurance of proper operation than do conventional check valves, which rely on gravity or the action of a light spring.

Building on significant prior experience with pumping heavy wood/plastic slurries with dual syringe pumps, substantial additional effort was made during Phase I to improve the reliable operation of the dual syringe pumps on the pilot system. A number of improvements over the basic design were implemented, including magnetic sensing of the position of the driving pistons. The pump now operates in highly reliable fashion.

The maximum pumpable concentration of wood flour slurries achieved during Phase I was 10 wt $\%$ wood with $10 \%$ moisture content, or $9 \mathrm{wt} \%$ wood on a dry basis. These slurries utilized 2.5 wt\% carboxymethylcellulose (CMC) as a suspension agent, for a total slurry solids content of about $11.5 \mathrm{wt} \%$. During testing, there were indications that wood flour slurries of at least 14 $w t \%$ would be pumpable with a bit of optimization work. The maximum pumpable concentration of composted MSW/SSS was in the range of $30 \mathrm{wt} \%$ dry basis. Also, $9 \mathrm{wt} \%$ wood $+10 \mathrm{wt} \%$ coal (dry basis) was readily pumpable. To attain higher biomass solids content than can be pumped, alternate methods are being considered. 


\section{Feed Heatup}

Energy recovery and feed preheating are important elements in the development of SWPO. The GA pilot plant was initially set up with a mixing tee to rapidly heat the incoming biomass feed slurry by mixing with supercritical water. This proved to be problematic because the supercritical water preheat temperature was limited by tube strength to about $650^{\circ} \mathrm{C}$ and so a relatively large amount of supercritical water was required. The biomass slurry was thereby diluted and oxidation of most of the biomass was required to attain the desired final gasifier temperature. It was also found that biomass feed slurry could not be preheated to near gasifier temperature in a heat exchanger without charring and plugging. It was found that preheat temperatures in excess of about $250^{\circ} \mathrm{C}$ are conducive to charring with wood slurry feeds. Preheating of corn starch is even more limited as it thickens and plugs quickly above about $60^{\circ} \mathrm{C}$. By slowly precooking cornstarch to form a paste, UHM was able to preheat corn starch to higher temperatures, but this process is not suitable for production operations. With limited biomass preheating up to $250^{\circ} \mathrm{C}$, limited SCW preheating up to $650^{\circ} \mathrm{C}$, and limited biomass feed concentration of $10-15 \mathrm{wt} \%$, insufficient biomass is available after partial oxidation to achieve economically viable hydrogen production. As previously mentioned and as further discussed below, a combination of preheat and partial oxidation utilizing a high heating value auxiliary fuel co-feed was finally utilized to attain acceptable gasification results.

\section{Gasifier Type}

Gasifier type and performance are essential elements for the development of the SWPO process. As noted in Table 3, both downflow vessel and horizontal tube gasifiers have been tested. A tube gasifier has less backmixing than a vessel gasifier, and is less prone to short circuiting or flow bypass, but is limited in temperature by tube strength and has higher heat losses than a vessel gasifier. Based on the Phase I tests and other information, a vessel gasifier now appears to be preferable to a tube gasifier. A vessel gasifier allows better temperature control and better heat conservation, and is amenable to the use of a corrosion resistant thermal sleeve. With such a thermal sleeve the reaction zone can be maintained at a temperature considerably above the allowable temperature of the pressure vessel. During Phase I, a thermal sleeve allowed tests to be conducted at $800^{\circ} \mathrm{C}$. Even higher temperatures are possible with this gasifier type. Reduction of gasifier surface area to reduce heat loss is a primary driver in the trend to pressurized gasifiers in coal gasification. This factor is likewise of key importance in biomass gasification, and is best achieved with a vessel gasifier.

One area of potential improvement in the performance of GA's downflow vessel gasifier is in the design of the feed injector nozzle. In the Phase I tests described here, a relatively large nozzle orifice of 0.180 -in. diameter was used to minimize the chance of nozzle plugging for a variety of slurried feedstocks. This resulted in a relatively slow velocity and poor dispersion of the feed entering the gasifier. Based on test observations, it is believed that the feed nozzle was overly large in orifice size, and that as a result relatively large globules of feed material were able to fall through the gasifier with insufficient opportunity to disperse and react. This in turn could result in char and tar formation and incomplete gas-phase reactions. Thus, future testing will evaluate a smaller nozzle orifice diameter with a higher feed injection velocity. 
Paragraph deleted due to proprietary content.

Thus, with modest improvements in GA's vessel gasifier design, improvements in gasification efficiencies and reduction of tar and char formation are likely. Future testing during Phase II will evaluate these improvements in vessel gasifier performance.

\section{Feed Type}

The SWPO process is ideally suited to wet, dirty feed materials that have low or negative value, and can improve the economics of hydrogen production. Several feed types were evaluated during Phase I, including corn starch as a reference feed for comparison with other studies. As shown in Table 1, a number of runs were carried out with corn starch feed at concentrations of 10 to $40 \mathrm{wt} \%$. All of these compositions were prone to thickening and plugging in the preheater at temperatures as low as $70^{\circ} \mathrm{C}$, which prevented the collection of satisfactory gasification data. One purpose of the corn starch runs was to allow comparison with laboratory-scale data from UHM. UHM (1999) reported no gasifier plugging at about $10 \mathrm{wt} \%$ corn starch and plugging at about $14 \mathrm{wt} \%$ corn starch, although the plugging is attributed to char formation as opposed to thickening during preheat. Thickening and char formation are probably related, though, as thickening during preheating results in solid agglomerations that are prone to char formation upon entry into the gasifier. It is notable that at $10 \mathrm{wt} \%$ corn starch, preheater plugging occurred in the GA pilot tests but not in the UHM laboratory-scale tests. This is thought to be due to the fact that the corn starch was precooked into a paste in the UHM tests.

Composted MSW/SSS available from the Bedminster Process and other similar composting processes was tested during Phase I as a good source of size-reduced feed for supercritical water gasification, minimizing the need for front end processing (shredding, grinding, etc.). Composted MSW/SSS can be pumped at over $30 \mathrm{wt} \%$ (dry basis), sufficient to support partial oxidation and gasification without the addition of coal or other auxiliary fuel. By contrast, sewage sludge and uncomposted sawdust or wood flour can only be pumped at concentrations between 10-15 wt\% (dry basis) maximum. Despite the pumpability of high solids content composted slurries, the advantages of composted MSW/SSS are offset by several factors. During composting, the organic material becomes depleted in hydrogen and heating value due to microbial action (aerobic digestion). This works against high hydrogen production. Compost also has a fairly high content of minerals and grit that are parasitic to the SWPO process and complicate grinding, pumping, heat exchange and pressure letdown in a SWPO system. Furthermore, a composter front end is expensive, adversely affecting the economics of the SWPO process, unless a composter already exists at the site. 
Paragraphs deleted due to proprietary content. 


\section{SWPO of Wood Slurries}

As noted earlier, Phase I testing was eventually focused on SWPO of wood slurries. Table 2-2 summarizes the tests carried out. Auxiliary fuel in the form of ethanol was used in these tests. Tests were carried out at both $650^{\circ} \mathrm{C}$ and $800^{\circ} \mathrm{C}$ nominal gasifier temperature. Run duration was approximately 4 hours. Conversion of carbon to gaseous products was incomplete, as indicated by the liquid (tar) and solid (char) products shown in Table 2-2. Much of this incomplete conversion is believed to be due to insufficient dispersion at the feed injection nozzle and insufficient solid particle residence time. Poor dispersion at the nozzle is consistent with the finding of unused $\mathrm{O}_{2}$ in the gaseous effluent from the gasifier. About one third of the oxygen in the effluent gas is residual oxidant, while the remainder is from the air introduced at the gasliquid separator to stabilize separator level control. Future tests during Phase II will include improvements in nozzle design and solid particle residence time, as discussed earlier.

Carbon balances in Table 2-2 are fairly good, in the range of $90 \%$. At least some of the missing mass is likely due to residual tar or char that was distributed in different parts of the system and difficult to collect. Improvements are planned for Phase II to provide clean-out access at various locations that will enable char removal between tests to improve the mass balances. The SWPO gasification results in Table 2-2 are interpreted and compared to results from other gasifiers in Section 3.3. 
TABLE 2-2. SUMMARY OF 9\% WOOD GASIFICATION RUNS

\begin{tabular}{|c|c|c|c|c|c|c|}
\hline Run Date: & $4 / 10 / 2002$ & $4 / 12 / 2002$ & 4/17/2002 & $4 / 18 / 2002$ & $4 / 23 / 2002$ & 4/24/2002 \\
\hline Feed (dry basis) & $9 \%$ wood & $9 \%$ wood & $9 \%$ wood & $9 \%$ wood & $9 \%$ wood & $9 \%$ wood \\
\hline Gasifier internal features $^{(1)}$ & $2 \mathrm{~J}$-screens & $1 \mathrm{~J}$-screen & $1 \mathrm{~J}$-screen & No J-screen & No J-screen & No J-screen \\
\hline Gasifier T, C & 650 & 650 & 800 & 800 & 650 & 800 \\
\hline \multicolumn{7}{|l|}{ Input } \\
\hline Run time min & 105 & 250 & 242 & 195 & 128 & 132 \\
\hline Oxygen g/min & 109 & 104 & 110 & 112 & 86 & 113 \\
\hline Stoich. EtOH g/min & 52.2 & 49.8 & 52.7 & 53.7 & 41.2 & 54.1 \\
\hline Excess EtOH g/min & 16.8 & 22.2 & 10.3 & 3.3 & 17.8 & 7.4 \\
\hline Feed $\mathrm{g} / \mathrm{min}$ & 367 & 345 & 350 & 336 & 330 & 347 \\
\hline CMC \% ${ }^{(2)}$ & 2.5 & 2.5 & 2.5 & 2.5 & 2.5 & 2.5 \\
\hline \multicolumn{7}{|l|}{ Output } \\
\hline Gas SCFM & 4.5 & 5.1 & 4.6 & 4.7 & 4.3 & 4.9 \\
\hline $\mathrm{H}_{2} \%$ & 18.6 & 21.1 & 17.0 & 18.8 & 25.3 & 16.9 \\
\hline $\mathrm{CH}_{4} \%$ & 16.3 & 16.7 & 13.6 & 14.9 & 15.7 & 13.3 \\
\hline $\mathrm{C}_{2} \mathrm{H}_{6} \%$ & 0.1 & 0.1 & 0.1 & 0.1 & 0.2 & 0.1 \\
\hline $\mathrm{CO} \%$ & 2.7 & 2.9 & 1.9 & 2.2 & 4.1 & 1.7 \\
\hline $\mathrm{CO}_{2} \%$ & 48.6 & 48.6 & 54.5 & 48.7 & 43.7 & 54.9 \\
\hline $\mathrm{N}_{2} \%$ & 10.4 & 8.0 & 9.5 & 11.2 & 8.1 & 9.7 \\
\hline $\mathrm{O}_{2} \%$ & 3.5 & 2.7 & 3.5 & 4.1 & 3.0 & 3.5 \\
\hline$\%$ Feed C in solid (char) & 6.9 & 2.7 & 3.5 & 2.7 & 0.5 & 0.2 \\
\hline$\%$ Feed C in liquid (tar) & 2.3 & 2.9 & 6.0 & 0.0 & 8.7 & 5.0 \\
\hline Carbon balance \% & 79 & 88 & 90 & 90 & 83 & 94 \\
\hline
\end{tabular}

Notes:

(1) - J-screens were used to increase solid particle residence time.

(2) - CMC is a suspension agent to prevent settling in the feed slurry. 
Figures 2-8 through 2-11 show sample traces of key variables for runs at maximum reactor temperatures of about $650^{\circ} \mathrm{C}$ and $800^{\circ} \mathrm{C}$. The temperature traces in Figures $2-8$ and $2-10$ are considerably more erratic than is typical for SCWO. This is believed to be an effect of insufficient nozzle dispersion. In both cases, there was significant char and ash buildup in the gasifier that likely contributed to more erratic temperature fluctuations later in the run. Better mixing is expected to reduce the temperature fluctuations considerably.

As shown in Figures 2-9 and 2-11, gaseous effluent from the system was monitored by online gas meters. In addition, grab samples were also checked by gas chromatography (GC) in the laboratory. In general the results of the GC and online meters were within $10 \%$ of one another, the only significant difference being that $\mathrm{CO}$ from the online infrared meter is erroneously high due to interference from $\mathrm{CO}_{2}$ and $\mathrm{CH}_{4}$. The $\mathrm{GC}$ results have been used for Table2-2. The presence of nitrogen in the effluent gas is primarily due to the diluting air stream used to aid in level control at the low pressure gas-liquid separator.

The results of the wood slurry plus ethanol auxiliary fuel tests confirmed that SWPO is a viable means of gasification and hydrogen production without the need for catalysts. Future work during Phase II will focus on improving SWPO performance and verifying long-term operability without plugging. 


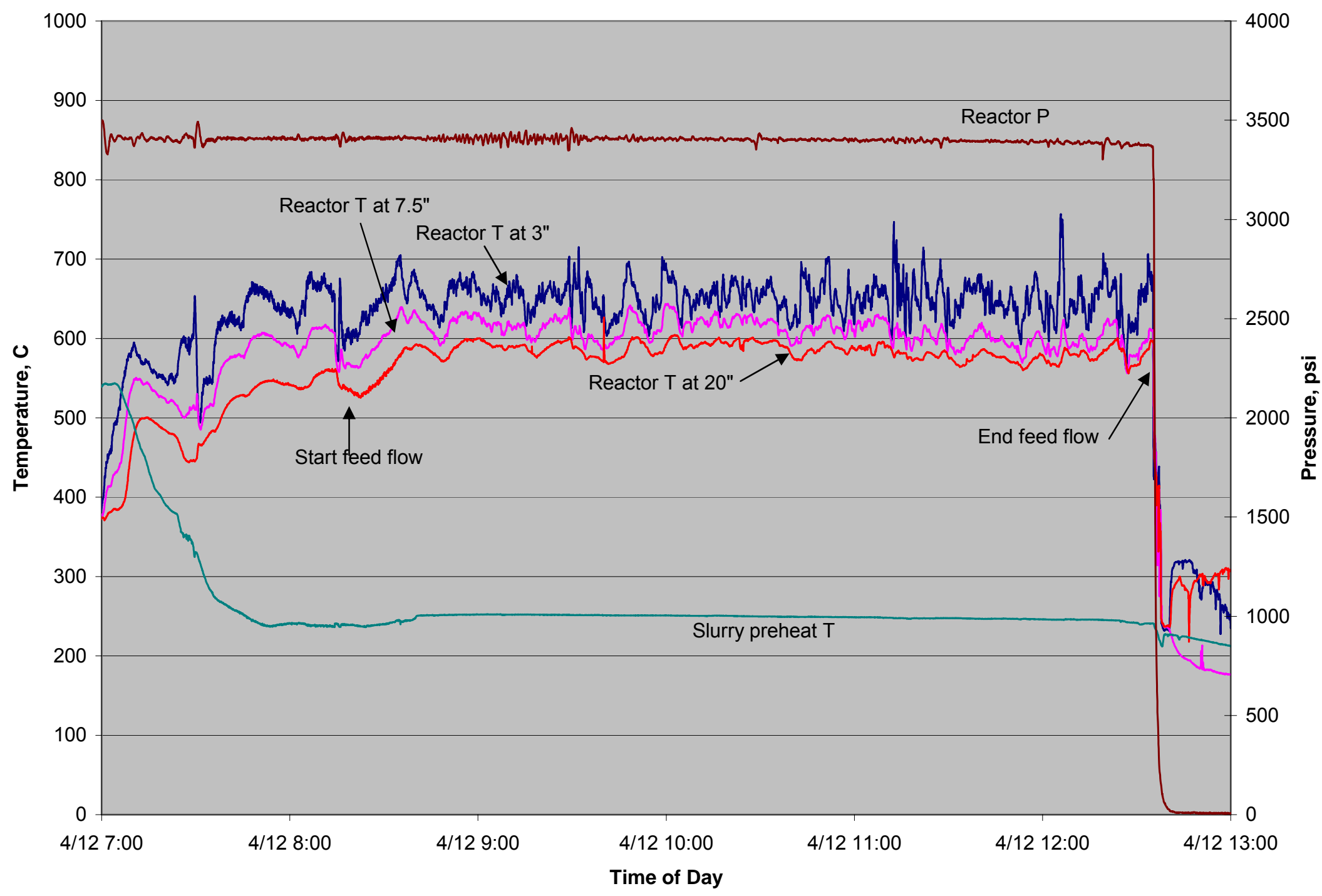

Figure 2-8. Temperature and pressure traces for SWPO run at $650^{\circ} \mathrm{C}$. 


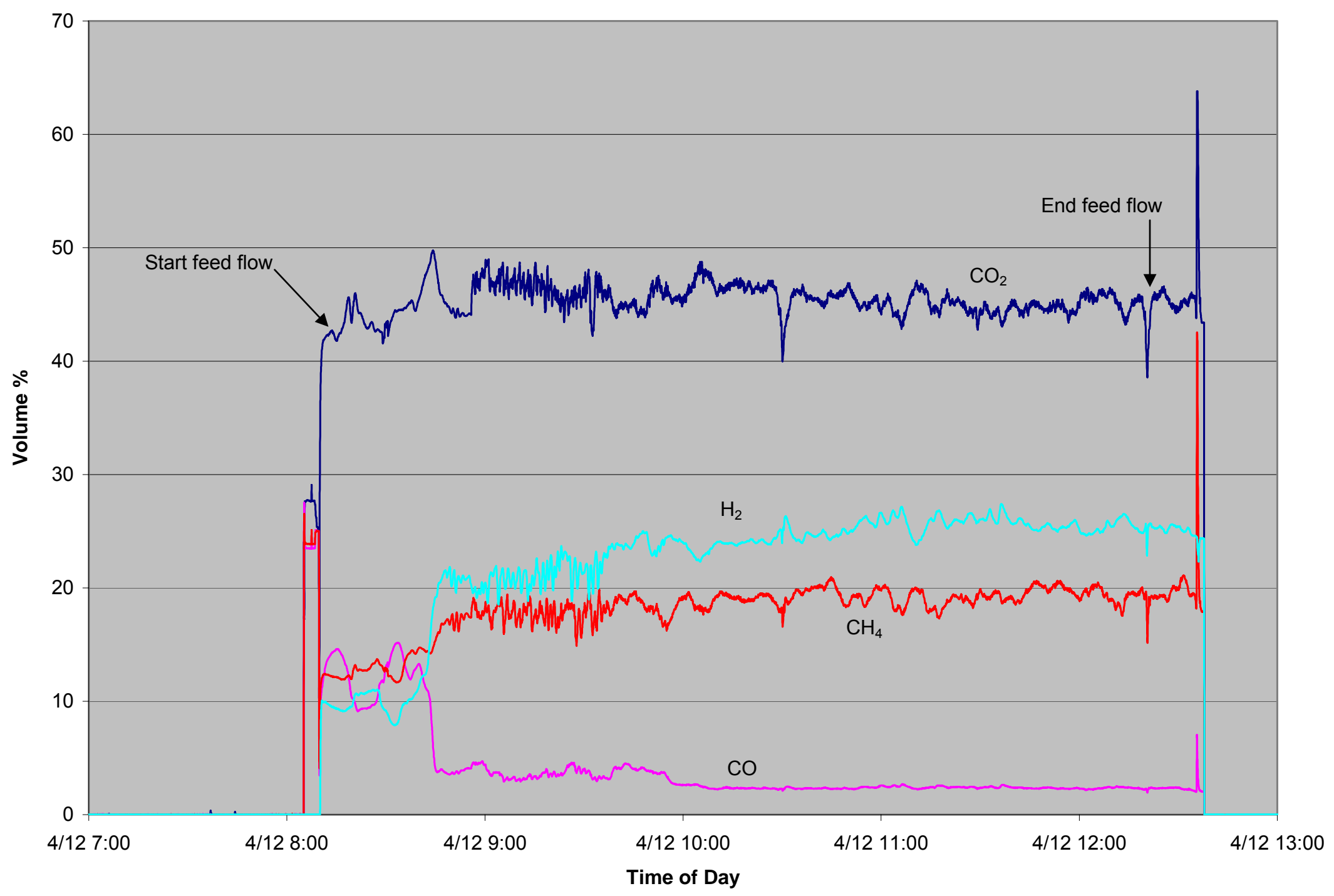

Figure 2-9. Gas analyzer traces for SWPO run at $650^{\circ} \mathrm{C}$. 


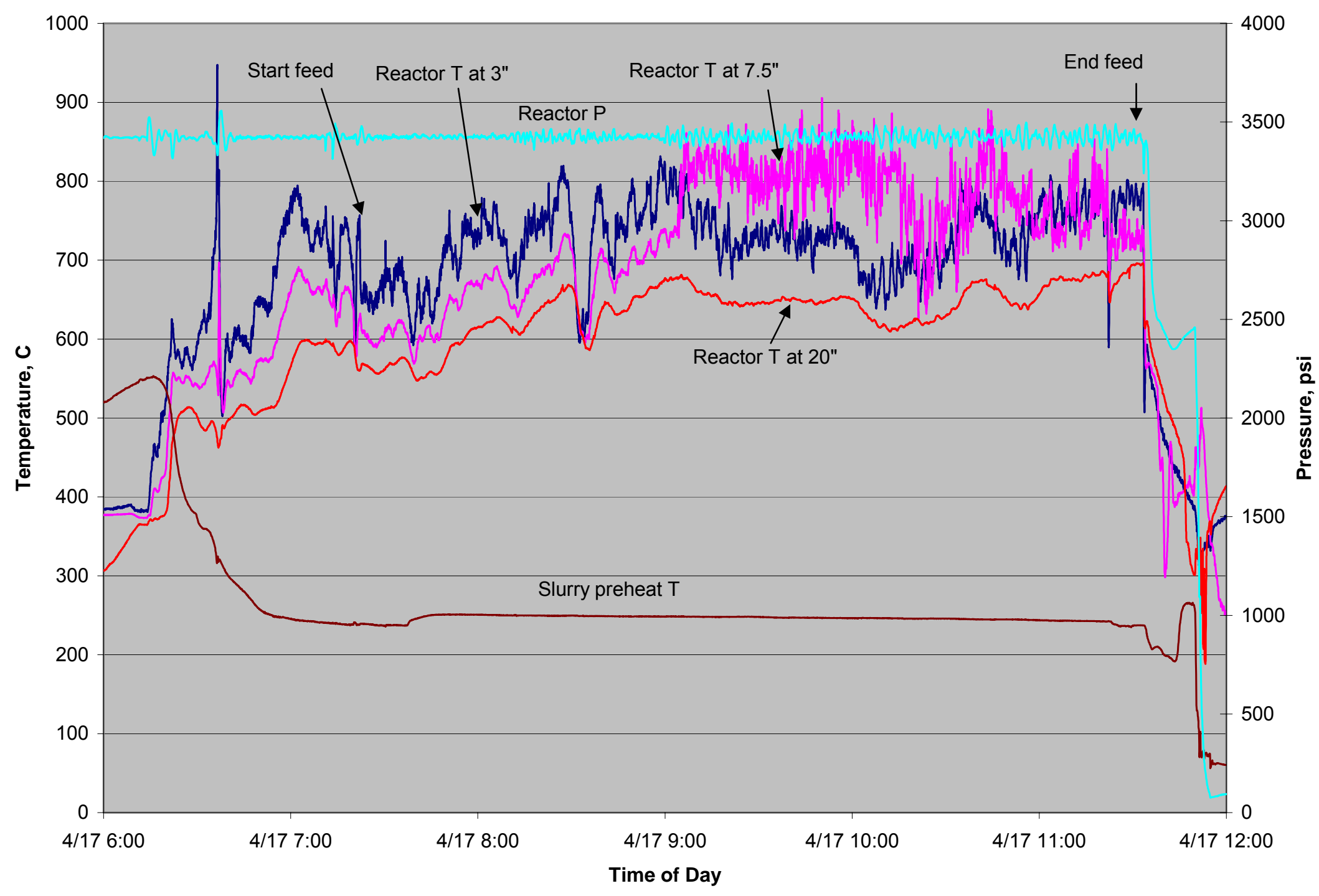

Figure 2-10. Temperature and pressure traces for SWPO run at $800^{\circ} \mathrm{C}$. 


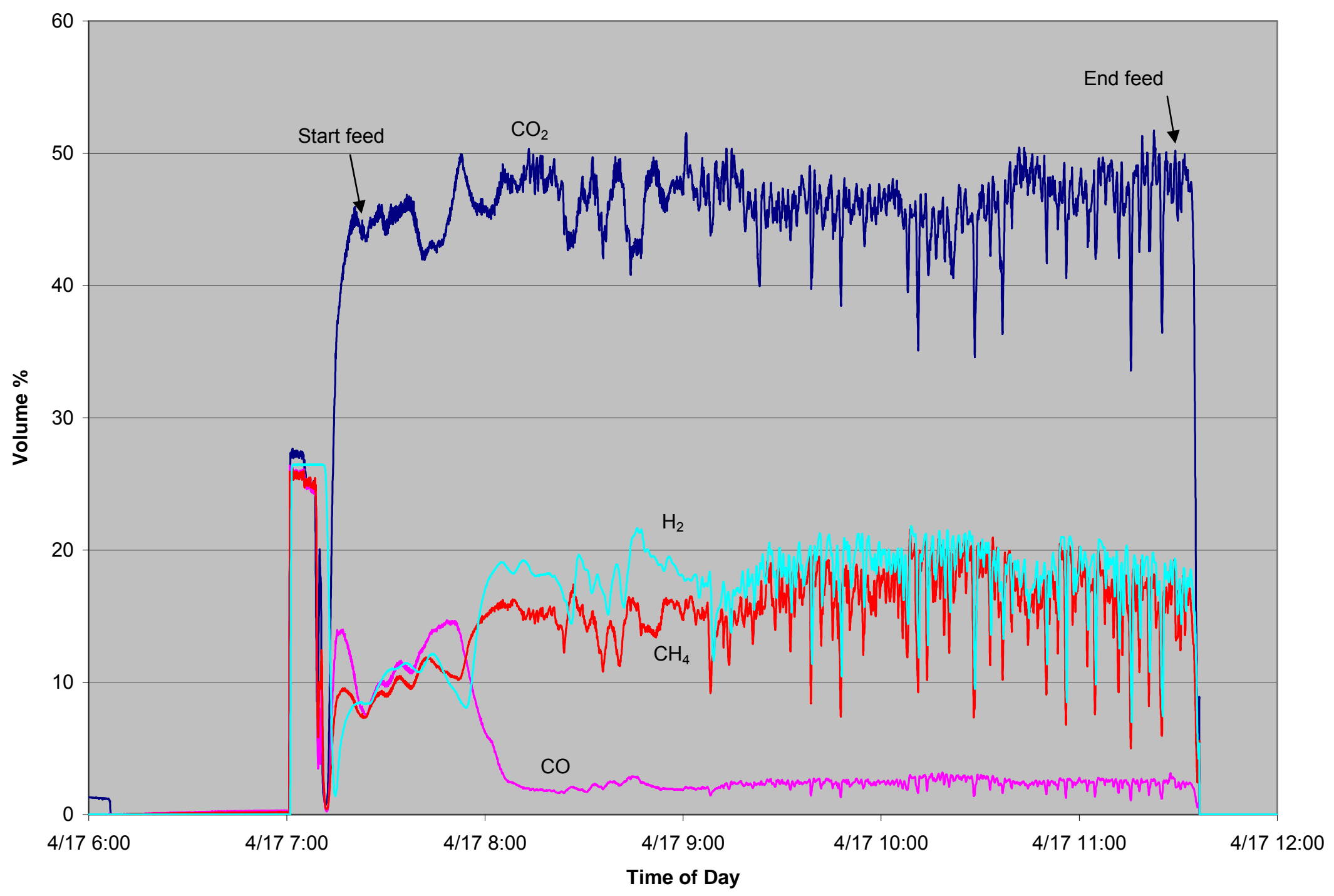

Figure 2-11. Gas analyzer traces for SWPO run at $800^{\circ} \mathrm{C}$. 


\section{Equilibrium Calculations}

Figures 2-12 and 2-13 compare the measured SWPO gasifier exit composition with the computed equilibrium composition as predicted by the Stanjan chemical equilibrium program (available on the web for example at http://grashof.engr.colostate.edu/tools/equil.html) at temperatures of $650^{\circ} \mathrm{C}$ and $800^{\circ} \mathrm{C}$, respectively. The figures also show the expected effect of temperature and pressure on equilibrium composition. The experimental data is from the wood slurry runs on $4 / 12 / 02$ and $4 / 17 / 02$ is indicated by symbols. These runs were carried out at $3400 \mathrm{psi}$ at $650^{\circ} \mathrm{C}$ and $800^{\circ} \mathrm{C}$ (nominal highest gasifier temperature), respectively. To obtain the equilibrium curves, the feed composition for the experimental runs was expressed as an equivalent composition of $\mathrm{H}_{2} \mathrm{O}, \mathrm{H}_{2}$, and $\mathrm{CO}_{2}$, and the equilibrium composition was calculated at various temperatures and pressures. There can be significant temperature changes as the gas mixture composition equilibrates - the temperature coordinate for the calculations is the final equilibrium temperature. For each gas species calculations were carried out at 5 pressures $30,500,1500,3400$, and 4000 psia. The arrows for each species indicate the direction of increasing pressure. Any single Stanjan equilibrium calculation is carried out at constant pressure and enthalpy, and includes only the species water, hydrogen, methane, carbon monoxide and carbon dioxide - there is essentially no free oxygen remaining at equilibrium conditions.

The equilibrium calculations represent a simplified, idealized case, and we do not necessarily expect to attain the calculated composition. Nevertheless, the theoretical calculations do provide useful guidelines and trends for comparison. The measured gas composition data corresponds to the equilibrium calculations quite well at $650^{\circ} \mathrm{C}$ (Figure $2-12$ ), but is significantly off at $800^{\circ} \mathrm{C}$ (Figure 2-13). This observation will be discussed further below. Carbon dioxide concentration is higher at $800^{\circ} \mathrm{C}$ due to the need to oxidize more feed to attain the higher gasifier temperature.

Figures 2-12 and 2-13 both show that higher pressures and lower temperatures generally favor methane as compared to hydrogen. This effect is not significant in terms of hydrogen end product; however, as the SWPO gasifier will be followed by a methane-steam reformer in a production plant. 
SWPO Equilibria

Pressures of $30,500,1500,3400,4000$ psia

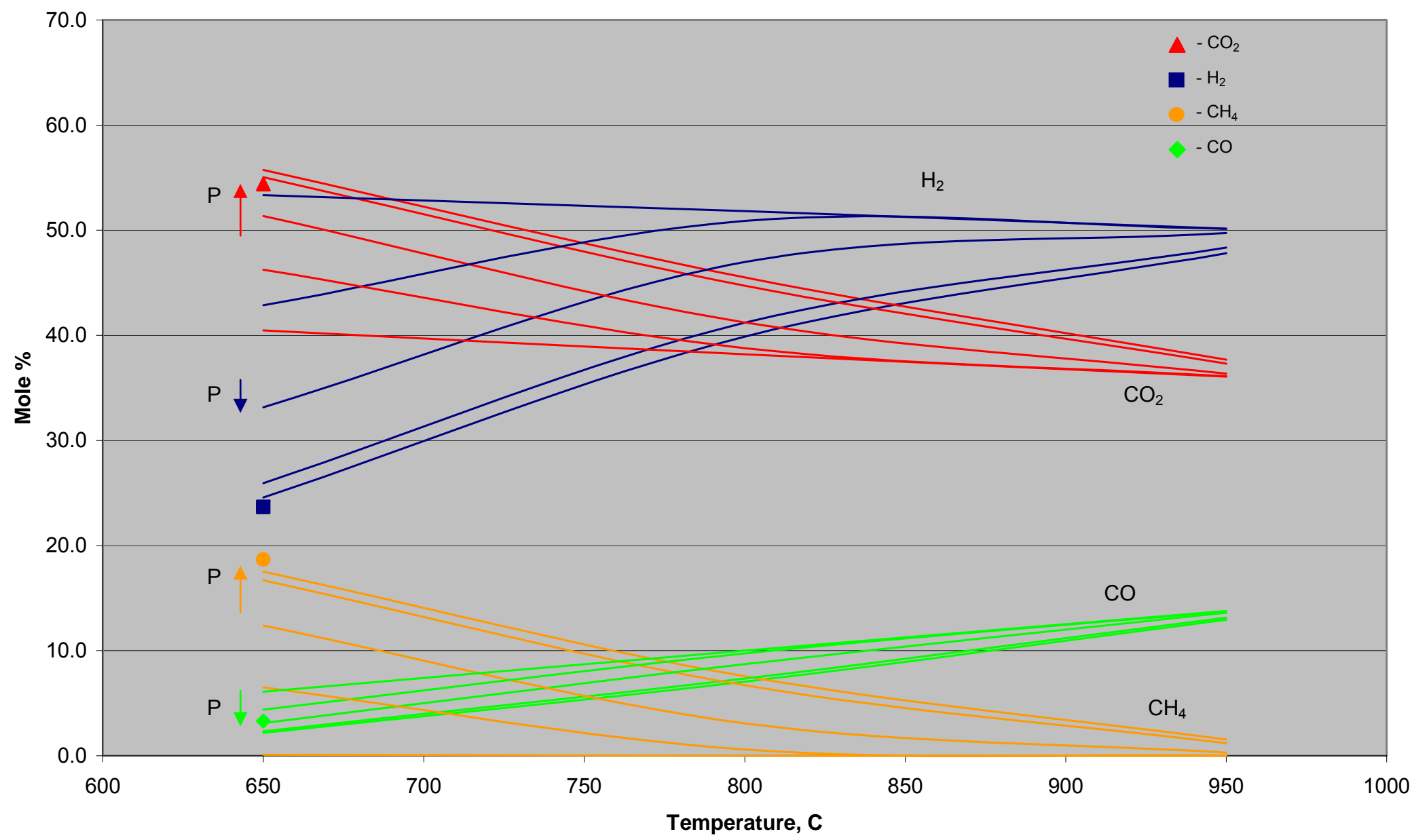

Figure 2-12. Comparison of GA results at $650^{\circ} \mathrm{C}$ with Stanjan equilibrium calculations. 
SWPO Equilibria

Pressures of $30,500,1500,3400,4000$ psia

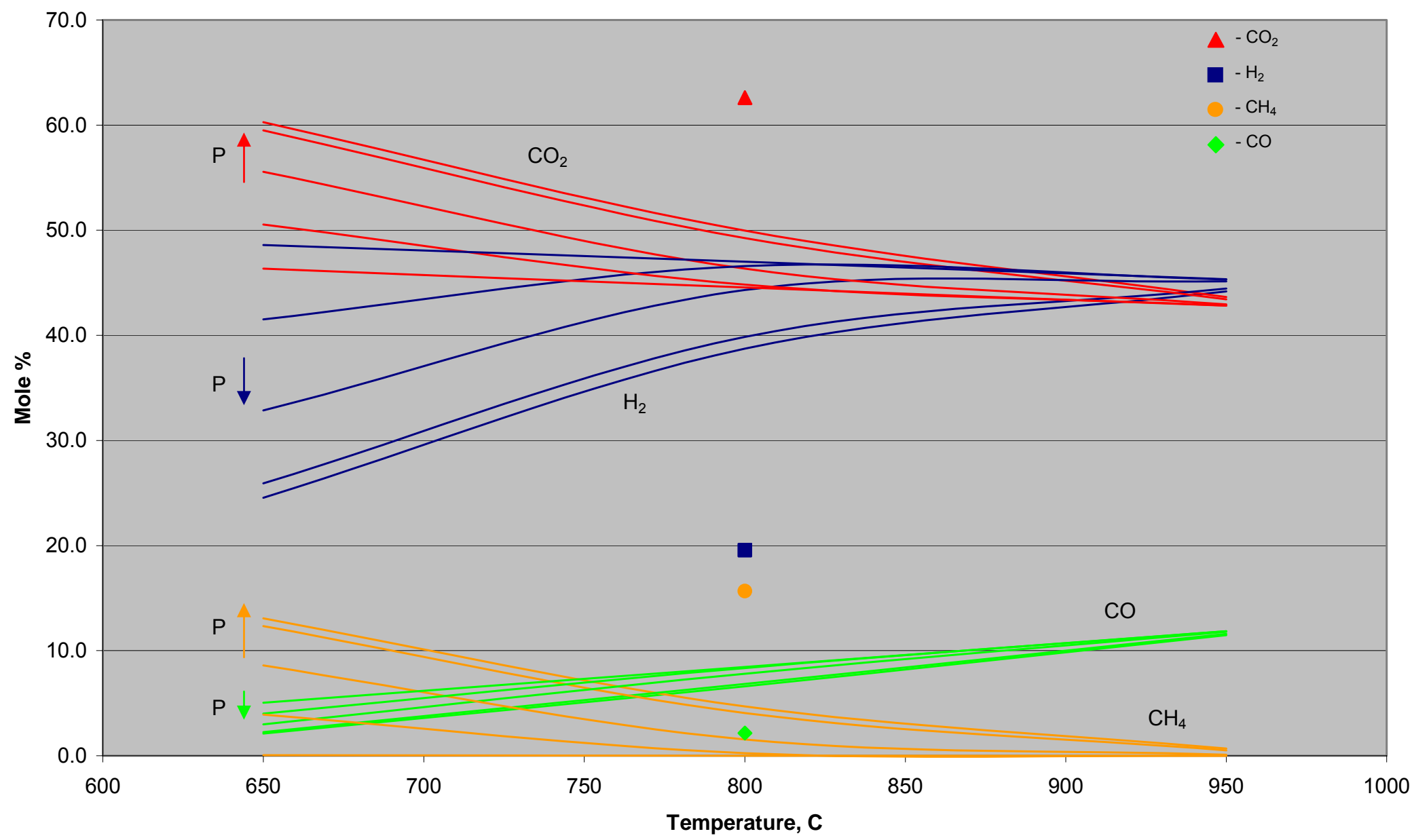

Figure 2-13. Comparison of GA results at $800^{\circ} \mathrm{C}$ with Stanjan equilibrium calculations. 
Figure 2-14 presents a scatter plot comparing both GA results and UHM results to Stanjan equilibrium calculations. The figure shows the higher expected hydrogen yields in an indirectly heated gasifier (such as the UHM SCW gasifier), as compared to a directly heated gasifier (such as the GA SWPO gasifier), in which there is dilution of the gaseous products by carbon dioxide from the oxidation reaction. In addition to the dilution effect, the excess carbon dioxide in a directly heated gasifier is unfavorable to the methane-steam reforming reaction

$$
\mathrm{CH}_{4}+2 \mathrm{H}_{2} \mathrm{O} \Leftrightarrow \mathrm{CO}_{2}+4 \mathrm{H}_{2}
$$

reducing the amount of hydrogen in the product gas. These are fundamental characteristics of the gasifier type. Schemes have been proposed to circumvent this problem by removing gas phase $\mathrm{CO}_{2}$ from the system. For example, Lin et al. (1999a,b) and Wang and Takarada (2001) describe the use of lime for in-situ sequestration of $\mathrm{CO}_{2}$ during supercritical water gasification of coal to improve gasification yields and reduce greenhouse gas emissions. This technique is another potential future improvement for SWPO.

As shown in Figure 2-14 (and as was seen in Figures 2-12 and 2-13), the GA results at $650^{\circ} \mathrm{C}$ tend to be close to equilibrium, while those at $800^{\circ} \mathrm{C}$ tend to deviate significantly. Furthermore, this trend was reproducible in that it held true for all 3 data points at each gasifier temperature. One reason the $800^{\circ} \mathrm{C}$ data points deviate from equilibrium is very likely insufficient time at temperature. Review of Figures 2-8 and 2-10 shows that there was considerably more temperature drop across the gasifier at $800^{\circ} \mathrm{C}$ as opposed to at $650^{\circ} \mathrm{C}$. However, even the trend of the data in going from $650^{\circ} \mathrm{C}$ to $800^{\circ} \mathrm{C}$ in Figure $2-14$ is sometimes wrong. For example, hydrogen content should increase at the higher temperature, but instead it decreases. The explanation for the peculiar behavior of the gas composition may have to do with erratic fuel/feed oxidation. As shown in Figure 2-10, gasifier temperatures were quite erratic at the higher temperature of operation, which was attributed to poor nozzle dispersion. It may be that the lower density reaction medium at $800^{\circ} \mathrm{C}$ was more susceptible to undispersed feed globules dropping through the gasifier, resulting in insufficient residence time and a poorer approach to equilibrium. Phase II tests with an improved nozzle design and gasifier internals to insure sufficient solids residence time should help answer this question.

It is important to note that equilibrium calculations pertain to composition of product gases and do not in any way reflect the yield attained or, more importantly, the economics of a process. 


\section{Comparison with Equilibrium}

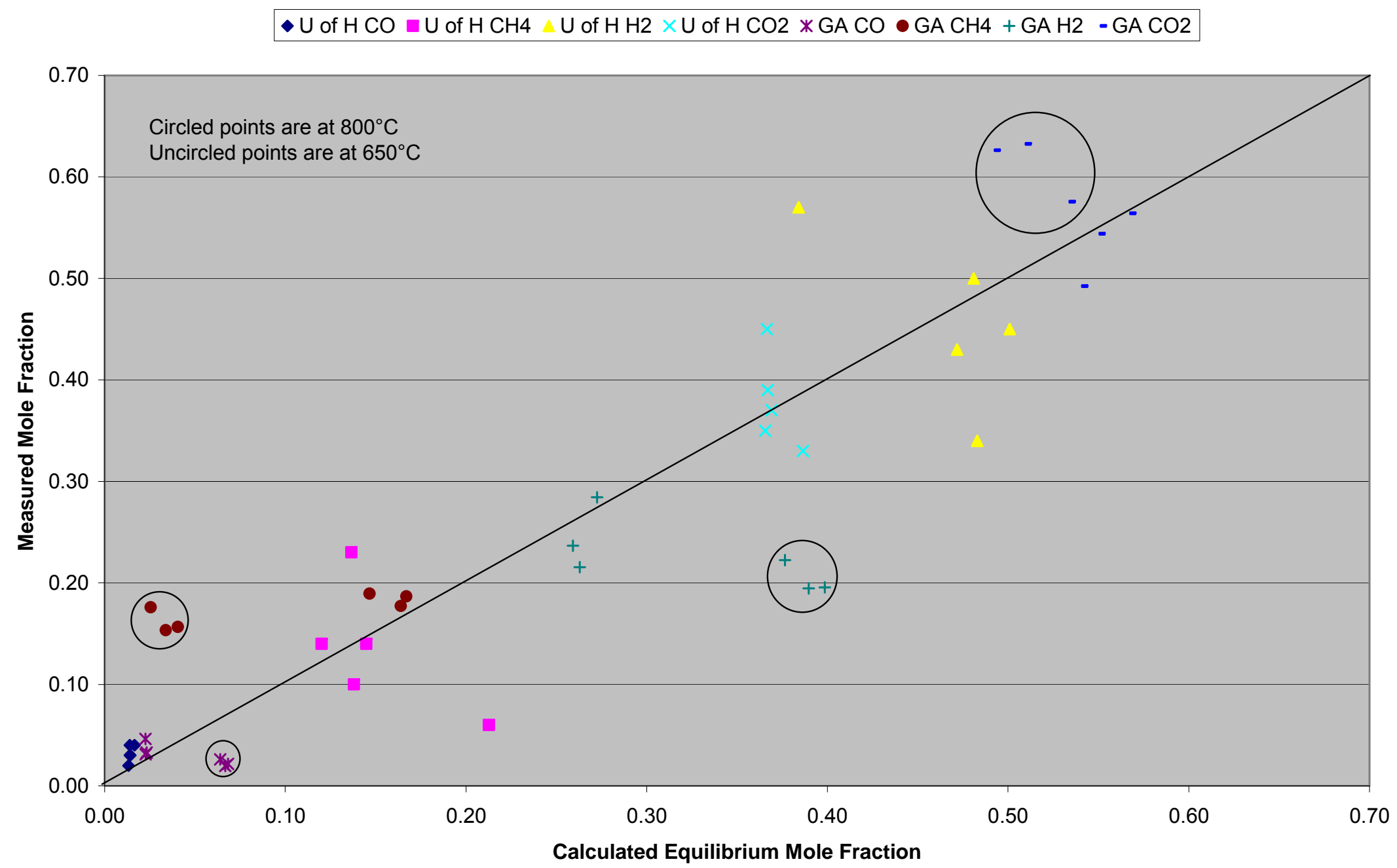

Figure 2-14. Comparison of GA and UHM results with Stanjan equilibrium calculations. 


\subsection{COMPARISON OF SWPO WITH OTHER GASIFIERS}

Tables 2-3 and 2-4 compare the results of the GA SWPO wood slurry tests in Table 2-2 with those of other gasifiers. Comparisons are given with both indirectly heated (Table 2-3) and directly heated or partial oxidation (Table 2-4) gasifiers. When comparing with indirectly heated gasifiers, only the unoxidized portion of the SWPO wood and ethanol is assumed to be available for gasifying when calculating the hydrogen yield, and the $\mathrm{CO}_{2}$ produced by oxidation is deleted from the product gas composition. When comparing with directly heated gasifiers, all of the SWPO wood and ethanol are included in the yield calculations. In either case the product gas composition is corrected to be on an oxygen- and nitrogen-free basis. (See Table 2-2 for the SWPO product gas oxygen and nitrogen content.)

As seen in Tables 2-3 and 2-4, in comparison to other gasifiers, the supercritical water gasification processes of GA and UHM have significantly higher steam to carbon ratios due to their processing of relatively dilute slurries. The high water content encourages the carbonsteam gasification (2) and water gas shift (3) reactions:

$$
\begin{aligned}
& \mathrm{C}+\mathrm{H}_{2} \mathrm{O} \Leftrightarrow \mathrm{CO}+\mathrm{H}_{2} \\
& \mathrm{CO}+\mathrm{H}_{2} \mathrm{O} \Leftrightarrow \mathrm{CO}_{2}+\mathrm{H}_{2}
\end{aligned}
$$

The effect of reaction 3 is clearly seen in Tables 2-3 and 2-4 in terms of the low CO content in the product gas of the SCW processes. This may provide an economic advantage in eliminating the need for shift reactors downstream of the SWPO gasifier.

Tables 2-3 and 2-4 show the product gas composition for the various gasifiers. In conjunction with the feed composition and feed rate, and the product gas flow rate, the compositional data can be used to calculate a gasification efficiency. To start with, the feed composition and feed rate are used to calculate the maximum possible $\mathrm{H}_{2}$ that could be formed, assuming that all feed carbon is converted to $\mathrm{CO}_{2}$ and all oxygen is provided by water. For example, for cellulose the chemical equation is:

$$
\mathrm{C}_{6} \mathrm{H}_{10} \mathrm{O}_{5}+7 \mathrm{H}_{2} \mathrm{O} \Leftrightarrow 6 \mathrm{CO}_{2}+12 \mathrm{H}_{2}
$$


TABLE 2-3. COMPARISON OF SWPO GAS PRODUCTION WITH INDIRECTLY HEATED GASIFIERS

\begin{tabular}{|c|c|c|c|c|c|c|c|c|c|c|c|c|c|}
\hline \multirow{2}{*}{ Organization } & \multirow{2}{*}{ Feed } & \multirow{2}{*}{$\begin{array}{l}\mathbf{T} \\
{ }^{\circ} \mathrm{C}\end{array}$} & \multirow{2}{*}{$\begin{array}{l}\text { P } \\
\text { psi }\end{array}$} & \multirow{2}{*}{$\begin{array}{c}\mathrm{H}_{2} \mathrm{O}: \mathrm{C} \\
\text { ratio }\end{array}$} & \multicolumn{5}{|c|}{ Product gas mol\% } & \multicolumn{2}{|c|}{$\begin{array}{c}\text { Max possible } \mathrm{H}_{2} \\
\text { yield, g/100g feed }\end{array}$} & \multirow{2}{*}{$\begin{array}{c}\text { Max } \\
\text { possible } \\
\text { gasification } \\
\text { efficiency, \% }\end{array}$} & \multirow{2}{*}{ Notes } \\
\hline & & & & & $\mathbf{H}_{2}$ & $\mathrm{CH}_{4}$ & $\mathrm{C}_{2}+$ & $\mathrm{CO}$ & $\mathrm{CO}_{2}$ & Feed & $\begin{array}{l}\text { Product } \\
\text { gas }\end{array}$ & & \\
\hline GA & $\begin{array}{c}9 \% \text { wood }+2.5 \% \\
\text { CMC }^{1}\end{array}$ & 650 & 3400 & 7.5 & 43.6 & 38.3 & 0.2 & 6.3 & 11.5 & 19.4 & 15.3 & 79 & $\begin{array}{l}\text { Yields based on unoxidized } \\
\text { organic }\end{array}$ \\
\hline GA & $\begin{array}{c}9 \% \text { wood }+2.5 \% \\
\text { CMC }^{1}\end{array}$ & 650 & 3400 & 6.7 & 40.0 & 31.6 & 0.3 & 5.6 & 22.5 & 20.1 & 17.5 & 87 & $\begin{array}{l}\text { Yields based on unoxidized } \\
\text { organic }\end{array}$ \\
\hline GA & $\begin{array}{c}9 \% \text { wood }+2.5 \% \\
\text { CMC }^{1}\end{array}$ & 800 & 3400 & 8.4 & 38.5 & 30.8 & 0.2 & 4.3 & 26.2 & 18.6 & 15.6 & 84 & $\begin{array}{l}\text { Yields based on unoxidized } \\
\text { organic }\end{array}$ \\
\hline GA & $\begin{array}{c}9 \% \text { wood }+2.5 \% \\
\text { CMC }^{1}\end{array}$ & 800 & 3400 & 9.9 & 44.7 & 35.4 & 0.2 & 5.2 & 14.5 & 17.5 & 21.1 & 121 & $\begin{array}{l}\text { Yields based on unoxidized } \\
\text { organic }\end{array}$ \\
\hline GA & $\begin{array}{c}9 \% \text { wood }+2.5 \% \\
\mathrm{CMC}^{1}\end{array}$ & 650 & 3400 & 7.1 & 47.4 & 29.5 & 0.4 & 7.7 & 15.0 & 19.7 & 16.8 & 85 & $\begin{array}{l}\text { Yields based on unoxidized } \\
\text { organic }\end{array}$ \\
\hline GA & $\begin{array}{c}9 \% \text { wood }+2.5 \% \\
\text { CMC }^{1}\end{array}$ & 800 & 3400 & 9.0 & 37.6 & 29.6 & 0.2 & 3.8 & 28.8 & 18.2 & 17.2 & 94 & $\begin{array}{l}\text { Yields based on unoxidized } \\
\text { organic }\end{array}$ \\
\hline UHM & $10.4 \% \mathrm{CS}^{2}$ & 650 & 4061 & 14.0 & 45 & 14 & 0.0 & 2 & 35 & 13.7 & 14.5 & 105 & UHM, 1997a \\
\hline UHM & $5 \%$ wood $+5.5 \%$ CS $^{2}$ & 650 & 4061 & 12.6 & 34 & 23 & 0.2 & 3 & 45 & 15.2 & 13.3 & 87 & UHM, 1997a \\
\hline UHM & $5 \%$ wood $+5.6 \%$ CS $^{2}$ & 650 & 4061 & 12.6 & 50 & 10 & 0.0 & 4 & 39 & 15.2 & 15.5 & 102 & UHM, 1997a \\
\hline UHM & $5 \%$ wood $+6.1 \%$ CS $^{2}$ & 650 & 4061 & 11.9 & 43 & 14 & 0.2 & 3 & 37 & 15.1 & 13.5 & 89 & UHM, 1997a \\
\hline UHM & $\begin{array}{c}11.5 \% \text { wood }+4.2 \% \\
\text { CS }^{2}\end{array}$ & 650 & 4061 & 7.6 & 57 & 6 & 0.0 & 4 & 33 & 15.9 & 15.2 & 95 & UHM, 1997b \\
\hline TNO & Waste biomass & 600 & 4351 & NA & 54 & 9 & NA & 3 & 34 & NA & NA & NA & TNO, 1998 \\
\hline Battelle & Wood & 826 & 25 & 0.8 & 21 & 16 & 5.8 & 43 & 13 & 18.0 & 12.5 & 70 & Craig and Mann, 1996 \\
\hline Battelle & Wood & 927 & 15 & 0.6 & 21 & 15 & 6.0 & 47 & 11 & 18.5 & 13.2 & 72 & Katofsky, 1993 \\
\hline Wright-Malta & Wood & 600 & 218 & 1.1 & 21 & 35 & 0.0 & 7 & 38 & 17.2 & 17.3 & 101 & Katofsky, 1993 \\
\hline $\mathrm{MTCl}$ & Wood & 697 & 15 & 2.6 & 50 & 8 & 0.4 & 22 & 19 & 17.8 & 14.9 & 84 & Katofsky, 1993 \\
\hline
\end{tabular}

Notes:

1. $\mathrm{CMC}$ is carboxymethylcellulose suspension agent.

2. Activated carbon catalyst. CS is corn starch. 
TABLE 2-4. COMPARISON OF SWPO GAS PRODUCTION WITH DIRECTLY HEATED GASIFIERS

\begin{tabular}{|c|c|c|c|c|c|c|c|c|c|c|c|c|c|c|}
\hline \multirow{2}{*}{ Organization } & \multirow{2}{*}{ Feed } & \multirow{2}{*}{$\begin{array}{l}\mathrm{T} \\
{ }^{\circ} \mathrm{C}\end{array}$} & \multirow{2}{*}{$\begin{array}{l}\text { P } \\
\text { psi }\end{array}$} & \multirow{2}{*}{$\begin{array}{c}\mathrm{H}_{2} \mathrm{O}: \mathrm{C} \\
\text { ratio }\end{array}$} & \multirow{2}{*}{$\begin{array}{c}\mathrm{O}_{2}: \text { Feed } \\
\text { mass } \\
\text { ratio }\end{array}$} & \multicolumn{5}{|c|}{ Product gas mol\% } & \multicolumn{2}{|c|}{$\begin{array}{l}\text { Max possible } \mathrm{H}_{2} \\
\text { yield, } \mathrm{g} / 100 \mathrm{~g} \text { feed }\end{array}$} & \multirow{2}{*}{$\begin{array}{c}\text { Max } \\
\text { possible } \\
\text { gasification } \\
\text { efficiency, \% }\end{array}$} & \multirow{2}{*}{ Notes } \\
\hline & & & & & & $\mathbf{H}_{2}$ & $\mathrm{CH}_{4}$ & $\mathrm{C}_{2}+$ & CO & $\mathrm{CO}_{2}$ & Feed & $\begin{array}{l}\text { Product } \\
\text { gas }\end{array}$ & & \\
\hline GA & $\begin{array}{c}9 \% \text { wood }+2.5 \% \\
\text { CMC }^{1,2}\end{array}$ & 650 & 3400 & 3.9 & 1.0 & 21.5 & 18.9 & 0.1 & 3.1 & 56.3 & 21.9 & 8.1 & 37 & $\begin{array}{l}\text { Yields based } \\
\text { on all organic }\end{array}$ \\
\hline GA & $\begin{array}{c}9 \% \text { wood }+2.5 \% \\
\text { CMC }^{1,2}\end{array}$ & 650 & 3400 & 3.6 & 0.9 & 23.6 & 18.6 & 0.2 & 3.3 & 54.3 & 21.9 & 9.7 & 44 & $\begin{array}{l}\text { Yields based } \\
\text { on all organic }\end{array}$ \\
\hline GA & $\begin{array}{c}9 \% \text { wood }+2.5 \% \\
\mathrm{CMC}^{1,2}\end{array}$ & 800 & 3400 & 4.0 & 1.1 & 19.5 & 15.6 & 0.1 & 2.2 & 62.5 & 22.0 & 7.7 & 35 & $\begin{array}{l}\text { Yields based } \\
\text { on all organic }\end{array}$ \\
\hline GA & $\begin{array}{c}9 \% \text { wood }+2.5 \% \\
\mathrm{CMC}^{1,2}\end{array}$ & 800 & 3400 & 4.1 & 1.2 & 22.2 & 17.6 & 0.1 & 2.6 & 57.5 & 22.2 & 9.3 & 42 & $\begin{array}{l}\text { Yields based } \\
\text { on all organic }\end{array}$ \\
\hline GA & $\begin{array}{c}9 \% \text { wood }+2.5 \% \\
\mathrm{CMC}^{1,2}\end{array}$ & 650 & 3400 & 4.0 & 0.9 & 28.4 & 17.7 & 0.2 & 4.6 & 49.1 & 21.6 & 9.7 & 45 & $\begin{array}{l}\text { Yields based } \\
\text { on all organic }\end{array}$ \\
\hline GA & $\begin{array}{c}9 \% \text { wood }+2.5 \% \\
\text { CMC }^{1,2}\end{array}$ & 800 & 3400 & 4.0 & 1.1 & 19.4 & 15.3 & 0.1 & 2.0 & 63.2 & 22.1 & 8.0 & 36 & $\begin{array}{l}\text { Yields based } \\
\text { on all organic }\end{array}$ \\
\hline IGT & Wood, air-blown ${ }^{3}$ & 830 & 460 & 0.7 & 0.3 & 25 & 18 & 0.2 & 19 & 38 & 17.3 & 10.6 & 62 & $\begin{array}{l}\text { Craig and } \\
\text { Mann, } 1996\end{array}$ \\
\hline IGT & Wood, $\mathrm{O}_{2}$-blown & 982 & 500 & 0.7 & 0.3 & 31 & 12 & 0.5 & 22 & 35 & 17.0 & 11.6 & 68 & Katofsky, 1993 \\
\hline TPS & Wood, air-blown ${ }^{3}$ & 870 & 20 & 0.3 & 0.5 & 37 & 0 & 0 & 46 & 16 & 17.3 & 11.1 & 64 & $\begin{array}{l}\text { Craig and } \\
\text { Mann, } 1996\end{array}$ \\
\hline Shell-bio & Wood $\mathrm{O}_{2}$-blown & 1085 & 352 & 0.2 & 0.5 & 38 & 0 & 0 & 48 & 14 & 17.0 & 11.1 & 65 & Katofsky, 1993 \\
\hline
\end{tabular}

Notes:

1. $\mathrm{CMC}$ is carboxymethylcellulose suspension agent.

2. Nitrogen- and oxygen-free basis used for product gas (see Table 2 for full composition).

3. Nitrogen-free basis used for product gas. 
The maximum possible $\mathrm{H}_{2}$ yield of the feed is expressed in terms of grams of hydrogen per 100 grams of dry (water-free) feed. The maximum possible hydrogen yield for cellulose is thus 24/162, or $14.8 \mathrm{~g}$ per $100 \mathrm{~g}$ of dry feed. The maximum possible hydrogen yield varies depending on the feed composition; some examples are given in Table 2-5. The table includes values for ethanol and wood, which are of particular relevance for the Phase I work, and SSS and trap grease, which are of particular relevance for the Phase II work. The organic portion of SSS actually has more potential for hydrogen production than does wood, but the high ash content of SSS reduces its potential on an overall basis. Trap grease, a favored fuel for Phase II and further development, has more potential for hydrogen production than does ethanol, the fuel used for Phase I testing. In general, the higher the heating value of a feed, the higher the maximum possible hydrogen yield.

TABLE 2-5. MAXIMUM POSSIBLE GASEOUS HYDROGEN YIELD

\begin{tabular}{|c|c|c|c|}
\hline Material & Formula & $\begin{array}{c}\text { Max g H } \mathbf{~ p e r ~} \\
\mathbf{1 0 0} \text { g dry feed }\end{array}$ & Reference \\
\hline Polyethylene & $\mathrm{CH}_{2}$ & 42.9 & \\
\hline Trap grease & $\mathrm{CH}_{1.89} \mathrm{O}_{0.13}$ & 35.2 & Czernik et al., 2002 \\
\hline Ethanol & $\mathrm{C}_{2} \mathrm{H}_{6} \mathrm{O}$ & 26.1 & \\
\hline GA Wood & $\mathrm{CH}_{1.26} \mathrm{O}_{0.62}$ & 17.3 & GA Phase I testing \\
\hline UHM Wood & $\mathrm{CH}_{1.46} \mathrm{O}_{0.68}$ & 16.7 & UHM, 1997a \\
\hline Mixed undigested SSS & $\begin{array}{c}\mathrm{CH}_{1.71} \mathrm{O}_{0.48} \mathrm{~N}_{0.1}, \\
28 \% \text { ash }\end{array}$ & 15.1 & European Commission, 2001 \\
\hline Cellulose & $\mathrm{C}_{6} \mathrm{H}_{10} \mathrm{O}_{5}$ & 14.8 & UHM, 1997a \\
\hline Corn starch & $\mathrm{C}_{6} \mathrm{H}_{11.4} \mathrm{O}_{5.7}$ & 13.7 & European Commission, 2001 \\
\hline Mixed digested SSS & $\mathrm{CH}_{1.84} \mathrm{O}_{0.53} \mathrm{~N}_{0.1}$, & 10.1 & \\
$50 \%$ ash & &
\end{tabular}

In the next step to calculate gasification efficiency, the product gas composition and flow rate are used to calculate the maximum possible $\mathrm{H}_{2}$ that could be formed from the product gas, again expressed as grams of hydrogen per 100 grams of dry (water-free) feed. (To actually achieve the maximum possible $\mathrm{H}_{2}$ from the product gas, all the $\mathrm{CH}_{4}$ would have to be reformed to $\mathrm{H}_{2}$ and $\mathrm{CO}$ by reaction 1 and all the $\mathrm{CO}$ would have to be converted to $\mathrm{H}_{2}$ and $\mathrm{CO}_{2}$ by reaction 3.) Comparison of the maximum possible yield from the product gas with the maximum possible yield from the feed results in the maximum possible gasification efficiency shown in the next to last columns of Tables 2-3 and 2-4. In actual practice, gasification yields will be somewhat lower.

For the indirectly heated gasifiers of Table 2-3, the maximum possible GA gasification efficiencies range from $79 \%$ to $94 \%$ (discounting the point that gives $121 \%$ efficiency), slightly lower than those for UHM that range from $87 \%$ to near $100 \%$. The carbon catalyst utilized by UHM may be responsible for the higher yields, but it is also possible that some of the catalyst itself was gasifying and artificially inflating yields. Note that UHM attributed a substantial catalytic effect to the wall of the nickel alloy tubular gasifier, an effect that would diminish for larger gasifiers such as GA's. The Wright-Malta gasifier also gives about $100 \%$ gasification efficiency, but the SCW gasifiers compare favorably to the Battelle and MTCI gasifiers. SWPO 
gasification efficiency is expected to increase with Phase II and future developments. An improved feed injection nozzle should substantially reduce tar and char formation, and an increased solid particle residence time should further reduce residual tar and char resulting in higher gasification yields. It should be noted that even for the initial results of the Phase I SWPO testing, the maximum possible product gas $\mathrm{H}_{2}$ yields already compare very favorably with the other gasifiers. This is a result of the ability of SWPO to take advantage of wet, dirty feedstocks such as grease trap waste (simulated by ethanol in Tables 2-3 and 2-4).

In comparison to the directly heated gasifiers of Table 2-4, the GA gasification efficiencies average about $40 \%$ while the gasification efficiencies for the IGT, TPS and Shell gasifiers average about $65 \%$. The primary reason for the lower GA gasification efficiency is the processing of a relatively dilute feed stream, combined with the limitation on heat recycle in that the feed slurry was only preheated to $250^{\circ} \mathrm{C}$. The high water to carbon ratio and the low degree of preheat required oxidation of a relatively large amount of fuel to reach the desired gasification temperature, reducing the maximum possible hydrogen yield of the product gas stream. The relatively large proportion of feedstock oxidation required is reflected in the high oxygen to feed ratio shown for SWPO in Table 2-4. GA anticipates that significant gains in gasification efficiency will be attained as SWPO is further developed. As mentioned previously for example, an improved feed injection nozzle should substantially reduce tar and char formation, and an increased solid particle residence time should further reduce residual tar and char resulting in higher gasification yields. In addition, higher feedstock slurry concentrations appear to be attainable with some development. As will be later discussed, there are also indications that significantly higher preheat temperatures are possible with some feeds. Similar to the indirect gasifier comparison, even for the initial results of the Phase I SWPO testing, the maximum possible product gas $\mathrm{H}_{2}$ yields are already approaching those of the conventional gasifiers.

While Tables 2-3 and 2-4 are useful in comparing the product gases and gasification efficiencies from the different gasification processes, they say little about the over-riding issue of economics. For example, when operating on woody biomass all of the gasifiers in Tables 2-3 and 2-4 require feedstock preparation. The non-SCW gasifiers typically require both feedstock size reduction and drying. In the extreme, work has been done to essentially covert cellulosic biomass to a coal-like material to allow feeding to a conventional gasifier (Wallman et al., 1996). The SCW gasifiers do not require feed drying, but may require a finer feed size. Feedstock preparation costs can have a significant effect on the process economics. Minimal feed preparation is required for SSS and grease trap wastes.

Another example of economic factors not reflected in Tables 2-3 and 2-4 is system and equipment design for the different processes. The Wright-Malta gasifier, which shows excellent gasification yields in Table 2-3, is a rotary kiln device that requires about 1 hour of residence time. In contrast, the other gasifiers have residence time requirements of only minutes or seconds. The SCW gasifiers are extremely compact reactors operating at elevated pressure, with relatively small capital costs. 
Section 5.1 will present an economic analysis of the SWPO process using the gasification yields obtained during the Phase I testing, which can only be expected to improve. Even given these conservatively low yields, by taking advantage of the particular capabilities of SWPO, economic production of hydrogen by avenues not available to the other technologies is enabled. Key SWPO features utilized in the economic analysis are:

- Ability of SWPO to process wet, dirty, negative value feedstocks

- No catalyst necessary, no concerns for bed blockage or catalyst fouling

- Low sulfur content of product gas due to inherent scrubbing action

- Production of low pressure steam

- $\quad$ Residence time of 1 minute or less

SWPO features that are not utilized in the economic analysis, but which may prove advantageous with further development of an optimized SWPO system include the following:

- Production of high pressure hydrogen

- Methane reforming without cooling and reheating the SWPO gasifier product gas

- Production of high pressure steam

- High pressure favors $\mathrm{CO}_{2}$ capture and sequestration 


\section{TASK 2: PILOT-SCALE DESIGN \& ANALYSIS}

Phase I testing identified a number of areas where design improvement might be possible. Most of these areas of improvement were discussed earlier in Section 3. These areas are discussed further below.

\section{Slurry pumping}

The dual syringe slurry pump was able to provide reliable pumping of thick slurries. At this point what is needed is long-term testing to demonstrate reliability, especially with the newly defined target feedstocks such as sewage sludge plus grease trap waste or biomass/plastic slurries. In the latter case, there is already some related long-term data. Slurries of sawdust mixed with ground plastic and rubber have been successfully pumped and fed to a SCWO reactor in thousands of hours of testing carried out for the U.S. Army. Slurries containing ground activated carbon have also been processed for hundreds of hours.

Paragraph deleted due to proprietary content.

\section{Feed Heatup}

As discussed earlier, we were unable to achieve reliable preheat of slurry feeds above about $250^{\circ} \mathrm{C}$ due to preheater plugging. This is consistent with previous GA experience with mixed wood/plastic/ rubber slurries in work carried out for the U.S. Army. Some of the difficulties experienced, however, may be due to the design of the heat exchanger as opposed to inherent properties of the slurries. At a typical feed rate of $350 \mathrm{~g} / \mathrm{min}$, the velocity in the heat exchanger was about $0.1 \mathrm{~m} / \mathrm{sec}$. The Durand equation may be applied (Perry and Green, 1997) to determine if this velocity is sufficient to keep the wood particles entrained in the liquid flow. The Durand equation is:

$$
\mathrm{V}_{\mathrm{M} 2}=\mathrm{F}_{\mathrm{L}}[2 \mathrm{gD}(\mathrm{s}-1)]^{0.5}
$$

Where $V_{\mathrm{M} 2}$ is the minimum velocity for complete suspension, $\mathrm{F}_{\mathrm{L}}$ is an empirical function of the particle diameter and the solid volume fraction of the feed, $g$ is the acceleration due to gravity, $D$ is the particle diameter, and $s$ is the ratio of solid to liquid density. Substituting in this equation for the maximum particle size of about $1 \mathrm{~mm}$ and using a water-saturated wood density of 1.1 , the velocity is marginally sufficient to keep the particles suspended at the preheater inlet, but insufficient as the slurry heats up past $170^{\circ} \mathrm{C}$ and drops in density. Furthermore, solids agglomeration may occur in the preheater and exacerbate any tendency toward settling.

The preheat heat exchanger incorporated in the GA pilot plant was designed to handle flowrates of at least $1 \mathrm{~kg} / \mathrm{min}$ and preheat temperatures of $400^{\circ} \mathrm{C}$ and higher. It is comprised of 12 straight legs, each with a length of about 6 meters. Thus, for the wood slurry tests the total residence time in the preheat exchanger was about 12 minutes. At the throughputs used, heatup of the feed required only a single leg of the heat exchanger - in the other 11 legs the temperature was essentially constant at $250^{\circ} \mathrm{C}$. This long residence time in the subcritical 
region may have contributed to char formation. Furthermore, the preheat exchanger was of a design that incorporated tight, welded hairpin turns for compactness. These tight turns may have served as accumulation points for char and ash, making the exchanger prone to plugging and difficult to inspect and clean. Effort will be devoted to this area in Phase II, as the preheat temperature has a significant effect on the process efficiency and economics. A straight, smaller diameter heat exchanger is planned that can be readily inspected and rodded out.

As will be subsequently described, there are several indications from the literature and from GA's prior experience that sewage sludge can be preheated significantly above $250^{\circ} \mathrm{C}$. Thus, preheat may be another factor making sewage sludge an ideal target feed.

\section{Gasifier Design}

Phase I testing was carried out in the absence of catalyst. Prior GA (1997) and UHM (1998a and b) SCWG studies used a packed bed catalyst. Use of a catalyst introduces problems of catalyst durability, poisoning, and bed plugging and handling. The Phase I results do not support the need for a catalyst - as was seen in Figure 2-14, GA's results at $650^{\circ} \mathrm{C}$ were as close to equilibrium as were the UHM results and as seen in Table 2-3, gasification efficiency was similar to UHM. Efficient gasification without catalysis is seen as a major advantage for SWPO.

Figures 2-12 through 2-14 showed significant quantities of methane at equilibrium in the SWPO gasifier. To improve hydrogen yields, a conventional catalytic methane-steam reformer can be used downstream of the SWPO gasifier. Use of a reformer should be facilitated by the clean gas product from the SWPO gasifier, which has been efficiently scrubbed during the cooldown and condensation of the SWPO gasifier effluent.

As discussed earlier, one area of potential improvement is in the design of the feed injector nozzle. In the Phase I tests, a relatively large nozzle orifice of 0.180 -in. diameter was used to minimize the chance of nozzle plugging for a variety of feedstocks. This nozzle size gives a low velocity feed jet and relatively poor mixing. Based on thousands of hours of SCWO testing carried out for the U.S. Army at similar flow rates with slurries of sawdust mixed with ground plastic and rubber, use of a 0.070 -in. nozzle should give better performance. For this size nozzle, particle size should be less than $1 \mathrm{~mm}$ diameter. Sewage sludge of $1 \mathrm{~mm}$ maximum diameter should likewise be amenable to this size nozzle. A nozzle of this type will be tested in Phase II.

Paragraphs deleted due to proprietary content. 
Phase I testing provided some key guidelines for the next step in development of the SWPO technology. These guidelines are summarized below:

1. Pumping tests indicate that a slurry feed concentration of about $12 \mathrm{wt} \%$ biomass solids is a conservative maximum. Composted municipal solid waste mixed with sewage sludge solids was pumped at about $30 \mathrm{wt} \%$ during Phase I, and other observations suggest that $14 \mathrm{wt} \%$ sawdust slurries should be pumpable. GA has previously had good success at pumping sewage sludge at solids contents of 10-14 wt\%, while literature sources claim that $15 \mathrm{wt} \%$ is pumpable. Economic projections utilizing 12 wt $\%$ thus represent a conservative minimum. If higher concentrations can be pumped, as appears likely, SWPO economics will be improved.

2. Feed preheat should be limited to $260^{\circ} \mathrm{C}$ to avoid char formation and plugging. Higher preheat temperatures may be possible with certain feedstocks or with improved heat exchanger designs, but these have not yet been demonstrated by GA.

3. Due to the limitations on feed slurry biomass concentration and feed preheat temperature, a high heating value waste must be coprocessed with the biomass in order to attain the desired gasifier temperature and still have sufficient feedstock for gasification. This is essentially the approach that evolved during Phase I testing, although the high heating value feed was the model compound ethanol as opposed to a waste material. Suitable high-heating value wastes are plastics, rubber, or trap grease.

4. Use a vessel-type gasifier as opposed to a pipe-type gasifier to allow higher gasifier operating temperatures and heat conservation.

5. Use a catalyst-free gasifier to enable long-term operation with dirty feed materials without plugging.

6. Use a high-energy nozzle giving high dispersion of the incoming feed to improve mixing and attain high gasification yields.

7. Use a methane-steam reformer on the clean SWPO product gas.

In keeping with the preceding guidelines, Figure 3-1 provides a process flow diagram (PFD) envisioned for the next phase of SWPO development. Feed to the system is comprised of two waste streams, a thick aqueous biomass slurry and a high heating value auxiliary fuel or slurry. For biomass slurries primary candidates are sewage sludge, manure sludge, and shredded sorted municipal solid waste (MSW) slurries. For the high heating value stream primary candidates are trap grease, plastic or rubber slurries, and coal or coke slurries. The easiest market entry may well be for the use of $12 \mathrm{wt} \%$ sewage sludge in conjunction with trap grease, 
as both of these wastes are ubiquitous and have reasonably well-defined negative value (i.e., the process will receive a well-defined credit for processing these streams). Additionally, waste grease is frequently recovered at municipal wastewater treatment plants where it is already contaminated with sewage (Wiltsee, 1998).

Referring to Figure 3-1, thick aqueous slurry is supplied to the system at high pressure via dual syringe pumps. Pressurized biomass slurry (or water during startup and shutdown) is fed to the preheater where it is preheated to a temperature of $260^{\circ} \mathrm{C}$, or other suitable temperature depending on established limits for a particular feed material. High-pressure high heating value material, referred to for convenience as auxiliary fuel, is simultaneously supplied to the gasifier. The fuel may be supplied by a separate pump as shown in Figure 3-1, or alternatively mixed in with the thick biomass slurry. In the case of trap grease, for example, the material as collected from restaurants contains a substantial fraction of water. The grease may be dewatered, heated, and pumped into the system as shown in Figure 3-1, or mixed in dilute form directly with dewatered sludge solids. Oxygen is combined with the preheated slurry and auxiliary fuel at the gasifier inlet. Partial oxidation of some of the organics results in a nominal gasifier temperature of $650-800^{\circ} \mathrm{C}$. The gasifier operates at $3400 \mathrm{psi}$. In the gasifier, the feed is converted primarily to $\mathrm{CO}_{2}, \mathrm{H}_{2} \mathrm{O}, \mathrm{H}_{2}, \mathrm{CH}_{4}$ and $\mathrm{CO}$. 


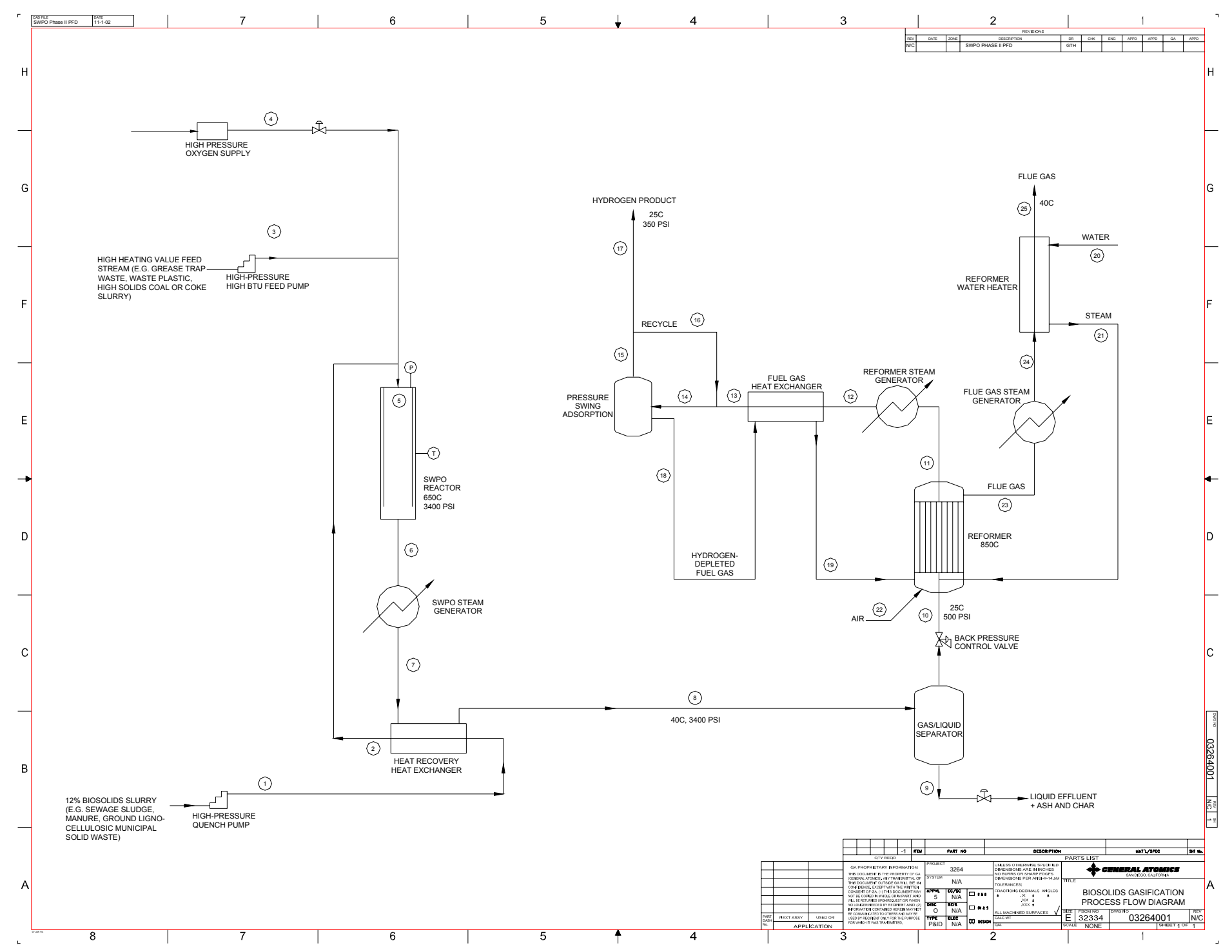

Figure 3-1. Process flow diagram for SWPO of sewage sludge with trap grease. 
The gasifier effluent is cooled to near ambient temperature by a series of heat exchangers, in the process generating steam and preheating the incoming feed slurry. The condensation of liquid in the gasifier effluent is a highly efficient scrubbing mechanism, partitioning salts, particulates, and other water-soluble materials such as $\mathrm{H}_{2} \mathrm{~S}$ into the liquid phase. Next, the cooled gasifier effluent is phase separated in a high pressure gas-liquid separator. Condensed liquid with dissolved material and suspended ash is removed from the bottom of the separator. The clean gas phase exits from the top of the separator and is reduced in pressure to about 500 psi. It then enters a steam reformer where methane and other light hydrocarbons will be converted to hydrogen. To enable the reforming, steam is added to the reforming gas at a steam:carbon ratio of $3: 1$. The catalytic reforming takes place at $850^{\circ} \mathrm{C}$, with the necessary temperature achieved by burning the hydrogen-depleted process offgas with ambient air.

The reformer flue gas is used to generate steam as well as preheat the incoming reformer water. Similarly, the hot reformed gas is used to generate steam and preheat the incoming fuel gas. Hydrogen is separated from the cool reformed gas using pressure swing adsorption (PSA). PSA requires that the feed gas contain at least $70 \%$ hydrogen. To meet this requirement, a portion of the hydrogen product gas from the PSA is recycled to the PSA feed gas. The hydrogen-depleted gas from the PSA is subsequently used to fire the reformer. Note that some but not all of these features will be tested during Phase II.

A mass and energy balance was carried out for the production-scale SWPO flowsheet of Figure 3-1. Table 3-1 lists key assumptions pertaining to these calculations. Gasification yields have been taken from GA's Phase I results with sawdust slurries, and are applied only to the organic fraction of the feed. Actual gas yields for SWPO mixtures of sewage sludge and grease have not yet been measured.

Table 3-2 presents the production-scale SWPO mass and energy balance. These mass and energy balance results were used as input to the economic study, described in the next section.

With regard to sewage sludge processing, a substantial amount of prior relevant work has been carried out. UHM (1996b, 1997b) reported several laboratory results showing good gasification using activated carbon catalyst, although ash precipitation plugged the narrow gasifier inlet within 2 hours. These tests utilized sludge concentrations from 2.1 to $7.7 \%$ in corn starch pastes in an indirectly heated tubular gasifier. Temperature and pressure conditions were 600$650^{\circ} \mathrm{C}$ and $4100-5100$ psi. UHM (1998a) later reports mixed gasification yields from sewage sludge, with some tests showing reasonable gasification and others showing poor yields and even apparent inhibition of gasification of the corn starch carrier. The reason for the widely varying results is not clear, but it was suggested that sulfur or heavy metals in some of the sludges may have poisoned catalytic sites on the gasifier wall. These results further support the non-catalytic approach advocated by GA. 
TABLE 3-1. SWPO PRODUCTION-SCALE MASS AND ENERGY BALANCE ASSUMPTIONS

\begin{tabular}{|l|c|c|}
\hline \multicolumn{1}{|c|}{ Description } & Assumption & Reference \\
\hline Plant size & $\begin{array}{c}30 \text { tons/day organic sludge solids, } \\
40 \text { tpd total solids (non-grease) }\end{array}$ & $\begin{array}{c}\text { Numerous POTWs of this size in } \\
\text { the US and worldwide }\end{array}$ \\
\hline $\begin{array}{l}\text { Sewage sludge suspended } \\
\text { solids content }\end{array}$ & $12 \%$ & $\begin{array}{c}\text { Phase I testing and prior GA } \\
\text { experience }\end{array}$ \\
\hline Sewage sludge ash content & $25 \%$ & UHM, 1997b \\
\hline Sludge preheat temperature & $260^{\circ} \mathrm{C}$ & Phase I testing \\
\hline Grease feed (wet, as collected) & $22-47$ tons/day & GA, 2002 \\
\hline Gasification yields & GA Phase I results & www.cgfa.org/news.htm \\
\hline Grease trap water content & $75 \%$ & \\
\hline $\begin{array}{l}\text { Grease heating value (water- } \\
\text { free) }\end{array}$ & None assumed & \\
\hline Heat loss & 16393 Btu/lb & \\
\hline
\end{tabular}

GA has reported on several pilot-scale tests with sewage sludge for a previous DOE contract (GA, 1997). Sludge concentrations of between 0.5 and $7.5 \%$ were tested. GA has pumped sewage sludge at concentrations up to $14 \%$ in other SCWO testing (GA, 1998). These feeds were thickened with a small amount of polymer, as opposed to the large amount of corn starch used in the UHM tests. Indirect heating up to the gasifier temperature of 300 to $660^{\circ} \mathrm{C}$ was used, with a gasifier pressure of $3400 \mathrm{psi}$. The longest run utilized an activated carbon catalyst in a downflow vessel gasifier. Feed was supplied to the system for a bit under 2 hours, at which point differential pressure was building across the catalyst bed, presumably due to char/ash accumulation, and a decision was made to terminate the run. Reasonably good hydrogen yields were obtained, with a product gas containing $25 \% \mathrm{H}_{2}$ as compared to $33 \% \mathrm{H}_{2}$ in the early UHM testing. It is important to note that the GA pilot-scale testing had far less catalytic surface area relative to the lab-scale test at UHM. Thus, the UHM suggestion that wall catalysis is important is questionable. 
TABLE 3-2. SWPO PRODUCTION-SCALE MASS AND ENERGY BALANCE

\begin{tabular}{|c|c|c|c|c|c|c|c|c|c|c|c|c|}
\hline Stream No. & 1 & 2 & 3 & 4 & 5 & 6 & 7 & 8 & 9 & 10 & 11 & 12 \\
\hline Stream Name & $\begin{array}{c}\text { Sludge } \\
\text { Solids } \\
\text { Feed }\end{array}$ & $\begin{array}{c}\text { Preheated } \\
\text { Sludge }\end{array}$ & $\begin{array}{l}\text { High } \\
\text { BTU } \\
\text { Feed }\end{array}$ & Oxygen & $\begin{array}{c}\text { Gasifier } \\
\text { Feed }\end{array}$ & $\begin{array}{l}\text { Gasifier } \\
\text { Effluent }\end{array}$ & $\begin{array}{l}\text { Partially } \\
\text { Cooled } \\
\text { Effluent }\end{array}$ & $\begin{array}{l}\text { Cooled } \\
\text { Effluent }\end{array}$ & $\begin{array}{l}\text { Liquid } \\
+ \text { Solid } \\
\text { Effluent }\end{array}$ & $\begin{array}{c}\text { Medium } \\
\text { Pressure } \\
\text { Gas }\end{array}$ & $\begin{array}{c}\text { Reformed } \\
\text { Gas }\end{array}$ & $\begin{array}{c}\text { Warm } \\
\text { Reformed } \\
\text { Gas }\end{array}$ \\
\hline Temperature, ${ }^{\circ} \mathrm{C}$ & 25 & 260 & 25 & 25 & 650 & 650 & 253 & 40 & 40 & 25 & 850 & 577 \\
\hline Pressure, bar & 235 & 235 & 235 & 235 & 235 & 235 & 235 & 235 & 235 & 37 & 35 & 35 \\
\hline Mass flow, kg/sec & 3.50 & 3.50 & 0.49 & 0.72 & 4.71 & 4.71 & 4.71 & 4.71 & 3.36 & 1.35 & 3.32 & 3.32 \\
\hline Heat flow, MW & 0.0 & 3.301 & 0.000 & 0.000 & 0.000 & 0.000 & -8.916 & -3.305 & 0.000 & 0.000 & 0.000 & -1.582 \\
\hline Solids, kg/sec & 0.42 & 0.42 & 0.00 & 0.00 & 0.42 & 0.11 & 0.11 & 0.11 & 0.11 & 0.00 & 0.00 & 0.00 \\
\hline Grease, kg/sec & 0.00 & 0.00 & 0.49 & 0.00 & 0.49 & 0.00 & 0.00 & 0.00 & 0.00 & 0.00 & 0.00 & 0.00 \\
\hline $02, \mathrm{~kg} / \mathrm{sec}$ & 0.00 & 0.00 & 0.00 & 0.72 & 0.72 & 0.00 & 0.00 & 0.00 & 0.00 & 0.00 & 0.00 & 0.00 \\
\hline $\mathrm{H} 2 \mathrm{O}, \mathrm{kg} / \mathrm{sec}$ & 3.08 & 3.08 & 0.00 & 0.00 & 3.08 & 3.26 & 3.26 & 3.26 & 3.26 & 0.00 & 1.85 & 1.85 \\
\hline $\mathrm{H} 2, \mathrm{~kg} / \mathrm{sec}$ & 0.000 & 0.000 & 0.000 & 0.000 & 0.000 & 0.023 & 0.023 & 0.023 & 0.000 & 0.023 & 0.057 & 0.057 \\
\hline $\mathrm{co}, \mathrm{kg} / \mathrm{sec}$ & 0.00 & 0.00 & 0.00 & 0.00 & 0.00 & 0.04 & 0.04 & 0.04 & 0.00 & 0.04 & 0.13 & 0.13 \\
\hline $\mathrm{CO} 2, \mathrm{~kg} / \mathrm{sec}$ & 0.00 & 0.00 & 0.00 & 0.00 & 0.00 & 1.14 & 1.14 & 1.14 & 0.00 & 1.14 & 1.22 & 1.22 \\
\hline $\mathrm{CH} 4, \mathrm{~kg} / \mathrm{sec}$ & 0.00 & 0.00 & 0.00 & 0.00 & 0.00 & 0.14 & 0.14 & 0.14 & 0.00 & 0.14 & 0.06 & 0.06 \\
\hline $\mathrm{N} 2, \mathrm{~kg} / \mathrm{sec}$ & 0.00 & 0.00 & 0.00 & 0.00 & 0.00 & 0.00 & 0.00 & 0.00 & 0.00 & 0.00 & 0.00 & 0.00 \\
\hline
\end{tabular}


TABLE 3-2. SWPO PRODUCTION-SCALE MASS AND ENERGY BALANCE (CONT'D)

\begin{tabular}{|c|c|c|c|c|c|c|c|c|c|c|c|c|c|}
\hline Stream No. & 13 & 14 & 15 & 16 & 17 & 18 & 19 & 20 & 21 & 22 & 23 & 24 & 25 \\
\hline Stream Name & $\begin{array}{c}\text { Cooled } \\
\text { Reformed } \\
\text { Gas }\end{array}$ & $\begin{array}{c}\text { Reformed } \\
\text { Gas w/ } \\
\text { Recycle }\end{array}$ & $\begin{array}{c}\text { PSA } \\
\text { Product }\end{array}$ & $\begin{array}{c}\text { PSA } \\
\text { Recycle }\end{array}$ & $\begin{array}{c}\text { Storage } \\
\mathrm{H} 2\end{array}$ & $\begin{array}{l}\text { PSA } \\
\text { Fuel } \\
\text { Gas }\end{array}$ & $\begin{array}{c}\text { Heated } \\
\text { PSA } \\
\text { Fuel Gas }\end{array}$ & $\begin{array}{c}\text { Reformer } \\
\text { Cold } \\
\text { Water }\end{array}$ & $\begin{array}{c}\text { Reformer } \\
\text { Heated } \\
\text { Water }\end{array}$ & $\begin{array}{c}\text { Combustion } \\
\text { Air }\end{array}$ & $\begin{array}{l}\text { Hot } \\
\text { Flue } \\
\text { Gas }\end{array}$ & $\begin{array}{c}\text { Warm } \\
\text { Flue } \\
\text { Gas }\end{array}$ & $\begin{array}{l}\text { Cold } \\
\text { Flue } \\
\text { Gas }\end{array}$ \\
\hline Temperature, ${ }^{\circ} \mathrm{C}$ & 25 & 25 & 25 & 25 & 25 & 25 & 569 & 25 & 249 & 25 & 850 & 100 & 40 \\
\hline Pressure, bar & 35 & 35 & 35 & 35 & 35 & 1 & 1 & 37 & 37 & 1 & 1 & 1 & 1 \\
\hline Mass flow, kg/sec & 3.32 & 3.44 & 0.14 & 0.11 & 0.02 & 3.30 & 3.30 & 1.97 & 1.97 & 4.53 & 7.83 & 7.83 & 7.83 \\
\hline Heat flow, MW & -7.317 & 0.000 & 0.000 & 0.000 & 0.000 & 0.000 & 7.319 & 0.0 & 5.3 & 0.0 & 0.0 & -7.5 & -6.1 \\
\hline Solids, kg/sec & 0.00 & 0.00 & 0.00 & 0.00 & 0.00 & 0.00 & 0.00 & 0.00 & 0.00 & 0.00 & 0.00 & 0.00 & 0.00 \\
\hline Grease, kg/sec & 0.00 & 0.00 & 0.00 & 0.00 & 0.00 & 0.00 & 0.00 & 0.00 & 0.00 & 0.00 & 0.00 & 0.00 & 0.00 \\
\hline $02, \mathrm{~kg} / \mathrm{sec}$ & 0.00 & 0.00 & 0.00 & 0.00 & 0.00 & 0.00 & 0.00 & 0.00 & 0.00 & 1.05 & 0.45 & 0.45 & 0.45 \\
\hline $\mathrm{H} 2 \mathrm{O}, \mathrm{kg} / \mathrm{sec}$ & 1.85 & 1.85 & 0.00 & 0.00 & 0.00 & 1.85 & 1.85 & 1.97 & 1.97 & 0.00 & 2.30 & 2.30 & 2.30 \\
\hline $\mathrm{H} 2, \mathrm{~kg} / \mathrm{sec}$ & 0.057 & 0.170 & 0.136 & 0.113 & 0.023 & 0.034 & 0.034 & 0.00 & 0.00 & 0.00 & 0.00 & 0.00 & 0.00 \\
\hline $\mathrm{co}, \mathrm{kg} / \mathrm{sec}$ & 0.13 & 0.13 & 0.00 & 0.00 & 0.00 & 0.13 & 0.13 & 0.00 & 0.00 & 0.00 & 0.00 & 0.00 & 0.00 \\
\hline $\mathrm{CO} 2, \mathrm{~kg} / \mathrm{sec}$ & 1.22 & 1.22 & 0.00 & 0.00 & 0.00 & 1.22 & 1.22 & 0.00 & 0.00 & 0.00 & 1.61 & 1.61 & 1.61 \\
\hline $\mathrm{CH} 4, \mathrm{~kg} / \mathrm{sec}$ & 0.06 & 0.06 & 0.00 & 0.00 & 0.00 & 0.06 & 0.06 & 0.00 & 0.00 & 0.00 & 0.00 & 0.00 & 0.00 \\
\hline $\mathrm{N} 2, \mathrm{~kg} / \mathrm{sec}$ & 0.00 & 0.00 & 0.00 & 0.00 & 0.00 & 0.00 & 0.00 & 0.00 & 0.00 & 3.47 & 3.47 & 3.47 & 3.47 \\
\hline
\end{tabular}


A number of relevant sewage sludge SCWO demonstration efforts have been underway in recent years. These studies emphasize the perceived importance of the sewage sludge market for SCW processes. HydroProcessing, LLC (HP) has processed polymer-thickened sewage sludge in the range of $7 \%$ sludge solids for hundreds of hours in a full-scale plant in an attempt to commercialize this application of the SCWO process. The HP plant, located in Harlingen, Texas, is comprised of two identical trains each processing 5 tpd of dry sludge solids. The system operates at $3800 \mathrm{psi}$. The maximum sludge preheat temperature is about $350^{\circ} \mathrm{C}$ (Griffith, et al., 1999), while the maximum reactor temperature is about $600^{\circ} \mathrm{C}$ (Griffith, 2000). Some solids accumulation also occurred in the heat exchangers and reactor, which required occasional flushes with dilute nitric acid (Wofford, 2002).

Chematur Engineering AB of Sweden is also actively pursuing SCWO of sewage sludge. They have reported on a $30-\mathrm{hr}$ test carried out in their pilot plant and sponsored by BOC and a consortium of 6 UK water companies (Patterson et al., 2001). For this test both 15\% raw sewage sludge and $15 \%$ digested sewage sludge were produced from dilute sludges by centrifugation without the addition of polymer. Both feeds were processed at $230 \mathrm{~kg} / \mathrm{hr}$ with no apparent problems. The sludges were preheated to $400^{\circ} \mathrm{C}$ and the final reactor temperature was about $600^{\circ} \mathrm{C}$, with an operating pressure of about 3400 psi. A 100 -hr test of sewage sludge was scheduled for late 2001 but no literature references have yet appeared. A Japanese licensee of Chematur, Shinko Pantec, has built a full-scale system for SCWO treatment of sewage sludge in Kobe, but again no further information is available in the literature.

Several of the preceding references pertain to SCWO as opposed to SWPO. The SCWO references nevertheless entail the same high-pressure pumping and feed preheating operations as does SWPO, and involve many similar considerations in reactor/gasifier design and pressure letdown, for example. It is important to note the indications that sewage sludge can be reliably pumped at $15 \%$ solids, and that preheat temperatures of at least $400^{\circ} \mathrm{C}$ may be workable with this feed. The above pre-commercial and commercial SCWO activities suggest that a consensus is developing that SCWO of sewage sludge can be competitive with current sludge disposal practices. SWPO of sewage sludge should have economics even more favorable than SCWO. In addition to producing the valuable byproduct of hydrogen, SWPO uses far less oxygen than SCWO, which is the major operating cost of a SCWO plant. 


\section{TASK 3: DEVELOPMENT PLAN}

This section is comprised firstly of an economic analysis based on the Phase I test results that demonstrates the economic viability of the SWPO process. Following the economic analysis, the technology development plan is described in terms of the subsequent program phases. Briefly, these are Phase II - Technology Development; Phase III - System Integration and Design; and Phase IV - Reduced-scale Demonstration of 5 tpd System. Commercialization of the technology would take place subsequent to Phase IV. The development plan is a work in progress that must be updated at the completion of each phase of development to incorporate the most recent information and to revise plans for future work. Finally, the development of a SWPO Business Plan is described. The Business Plan itself is included as Appendix C.

\subsection{ECONOMIC ANALYSIS}

Identification of economically viable applications for hydrogen production has been a pacing factor in the development of the hydrogen economy. For hydrogen production from biomasstype feedstocks, economic viability has been dependent upon low-cost feedstocks and the coproduction of other useful chemical materials such as adhesive constituents or activated carbon (Czernik et al., 1999; Evans et al., 2001). GA has identified an economically viable application for hydrogen production based on the ability of the SWPO process to handle dirty, high moisture municipal waste feedstocks. Specifically, by co-processing sewage sludge in combination with grease trap waste, SWPO can transform feedstocks with a high negative value into hydrogen at highly competitive rates. Besides hydrogen, the coproducts of the SWPO process are steam (for possible power generation), clean water, inert ash, and reduced environmental degradation from sludge and trap grease disposal.

Because of its generally high negative value, municipal sewage sludge is a key target feed for early implementations of SWPO technology. This feedstock is plentiful, sustainable, and an ever-increasing disposal problem for municipalities of all sizes. As previously discussed, GA has successful prior experience with gasification of this feed, and related work in the literature is generally encouraging. Phase I testing and prior GA work with sewage sludge, however, indicate that the process may be limited to slurries with less than $15 \%$ organic solids and preheating may be limited to only about $250^{\circ} \mathrm{C}$. The Phase I tests showed that a high heating value waste can be co-processed as an auxiliary fuel in the SWPO unit to overcome these limitations. Waste grease is an ideal candidate for the high heating value waste, as it has a modest negative value and is readily available in municipalities in rough proportion to sewage sludge. This auxiliary fuel feedstock is also plentiful, sustainable, and a chronic disposal problem in cities across the country. An economic analysis has therefore been carried out for co-processing of sewage sludge and waste grease. As the analysis shows, this scenario produces hydrogen at highly competitive rates. Furthermore, due to the ability of SWPO to process virtually any wet, dirty waste, once a market foothold is established with sludge/grease, candidate biomass feedstocks may be expanded to include materials such as sorted municipal solid waste, animal manures, and agricultural byproducts that can be co-processed with other auxiliary fuel feedstocks such as shredded plastic and rubber and low grade coal or petroleum 
coke. SWPO thus has the potential to become a major waste cleanup technology, converting urban wastes of all types into clean distributed energy and hydrogen.

Most municipalities within the U.S. generate both primary and secondary sludges during the treatment of sewage. The process schematic for the Encina Wastewater Authority plant, located in Carlsbad, CA, shown in Figure 4-1, includes process steps that are representative of many such facilities. In primary treatment, wastewater first passes through a screen that filters out large debris. It then passes through a grit removal chamber, a long, shallow trough in which dense particles such as sand and clay settle to the bottom. After passing through the screen and grit chamber, the process stream is directed into a primary sedimentation tank, where suspended material settles out to form primary sludge and grease floats to the surface and is skimmed off. The wastewater then undergoes secondary treatment. In a typical process, the wastewater from the primary sedimentation tank is directed to an activated-sludge tank where aeration is provided to stimulate bacterial growth. Bacteria break down organics present in the water (aerobic digestion), which then flows to a secondary sedimentation tank. The bacteria-rich sludge settling in this tank is called secondary sludge or activated sludge. Some of this activated sludge is recycled to the aeration step to stimulate continuous bacterial growth.

Mixed primary and secondary sludge is typically about $6 \mathrm{wt} \%$ solids, with the sludge solids containing approximately $25 \%$ nonvolatile material, primarily sand and clay. With conventional sewage sludge practices at municipal installations, the mixed sludge is sent through an anaerobic digester, where it is partially metabolized by bacteria, producing $\mathrm{CH}_{4}, \mathrm{CO}_{2}$, and other by-products. The combustible gases produced may then be collected and used to generate heat for the digestion tanks and buildings, and to fuel gas engines for power generation for use in the plant. Residual solids from the anaerobic digestion step are depleted of a portion of their organic matter, and thus have higher nonvolatile content in comparison to undigested sludge. Table 4-1 shows typical compositions for mixed sludge before and after digestion, along with the compositions of corn starch and woody biomass for comparison. Note that the mole ratios of carbon and hydrogen with respect to oxygen are higher for mixed or digested sewage sludge than for corn starch or woody biomass. Thus, higher yields of hydrogen should be possible from the organic portion of sewage sludge than from corn starch or woody biomass. 


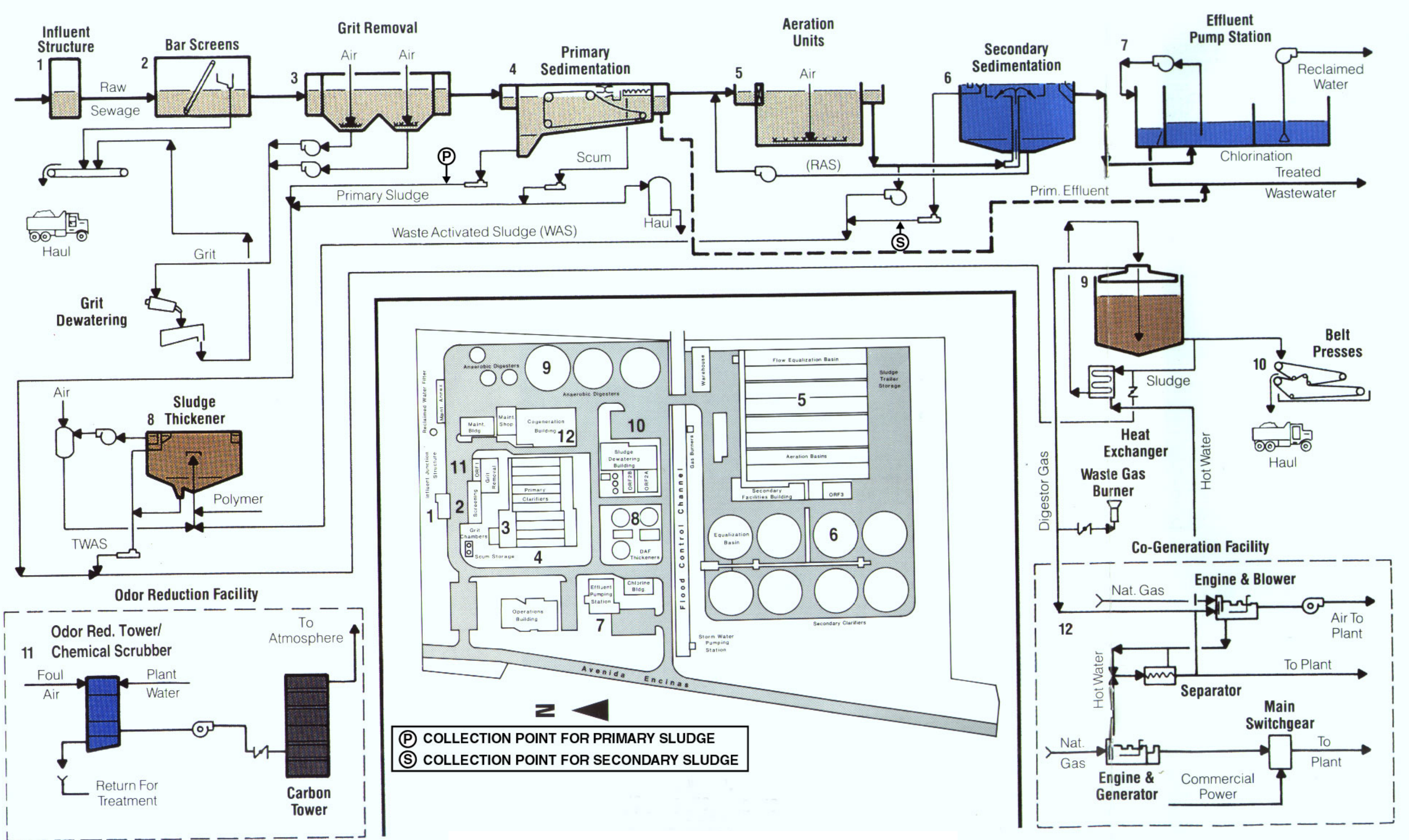

Figure 4-1. Encina Process Schematic and Site Plan 
GA-C24239

TABLE 4-1. TYPICAL COMPOSITION OF SOME BIOMASS MATERIALS

\begin{tabular}{|l|c|c|c|c|c|c|c|c|}
\hline & \multicolumn{2}{|c|}{$\begin{array}{c}\text { Mixed Sewage } \\
\text { Sludge }\end{array}$} & \multicolumn{2}{c|}{$\begin{array}{c}\text { Digested Sewage } \\
\text { Sludge }\end{array}$} & \multicolumn{2}{c|}{ Corn Starch $^{(\mathrm{b})}$} & \multicolumn{2}{c|}{ Woody Biomass $^{(\mathrm{c})}$} \\
\hline Element & $\begin{array}{c}\text { Ash-Free } \\
\text { Wt \% (dry) }\end{array}$ & $\begin{array}{c}\text { Mole } \\
\text { ratio }\end{array}$ & $\begin{array}{c}\text { Ash-Free } \\
\text { Wt \% (dry) }\end{array}$ & $\begin{array}{c}\text { Mole } \\
\text { ratio }\end{array}$ & $\begin{array}{c}\text { Ash-Free } \\
\text { Wt \% (dry) }\end{array}$ & $\begin{array}{c}\text { Mole } \\
\text { ratio }\end{array}$ & $\begin{array}{c}\text { Ash-Free } \\
\text { Wt \% (dry) }\end{array}$ & $\begin{array}{c}\text { Mole } \\
\text { ratio }\end{array}$ \\
\hline Carbon & 51.0 & 2.1 & 49.0 & 1.9 & 41.1 & 1 & 51.4 & 1.6 \\
\hline Hydrogen & 7.4 & 3.6 & 7.7 & 3.5 & 6.5 & 2 & 6.1 & 2.3 \\
\hline Oxygen & 33.0 & 1 & 35.0 & 1 & 52.4 & 1 & 42.3 & 1 \\
\hline Nitrogen & 7.1 & 0.2 & 6.2 & 0.2 & 0 & 0 & 0.2 & 0.0 \\
\hline Sulfur & 1.5 & 0.0 & 2.1 & 0.0 & 0 & 0 & 0.1 & 0.0 \\
\hline & & & & & & & & \\
\hline $\begin{array}{l}\text { Nonvolatile } \\
\text { wt\% }\end{array}$ & 28 & - & 50 & - & 0.0 & - & 0.9 & - \\
\hline
\end{tabular}

References:

a - European Commission, 2001.

b - UHM, 1997b

C - Mann, 1995

Following volume reduction by anaerobic digestion, the treated sewage sludge is dewatered to about $30 \mathrm{wt} \%$ solids and this residue is now termed biosolids. (Some definitions of biosolids also require that the material is satisfactory for beneficial application to the land, e.g., sufficiently low in pathogens, metal content, etc.) The dewatered sludge solids may be disposed of by incineration, landfilling, or land amendment. Incineration is now the least favored means of disposal. Land filling and land amendment are currently in widespread use in the U.S., but costs continue to increase as environmental concerns increase.

As an alternative to conventional sludge digestion and disposal, undigested sludge from municipal wastewater treatment works can be treated via SWPO. SWPO can eliminate the need for anaerobic digestion and greatly reduce the quantity of residual material requiring further disposal, with a concomitant reduction in disposal costs. GA has demonstrated SCWG of $11 \%$ sewage sludge in a prior study for DOE (GA, 1997), as well as pumping of up to $14 \%$ sewage sludge derived solids (GA, 1998), and this work, together with the Phase I results, forms the basis for the economic analysis presented here.

As previously mentioned, waste grease is a good candidate for auxiliary fuel for the SWPO process. The primary sources of waste grease are grease traps at restaurants and food processing plants, and grease recovered at sewage treatment plants. Grease traps are used to prevent plugging of sewer pipes with solidified grease. The traps accumulate grease over time and must be regularly pumped out. In most locations in the U.S. this pumping is carried out by service companies that collect the grease, dewater it, and then dispose of the byproduct in a 
landfill. The amount of trap grease generated per capita is about $13 \mathrm{lb} /$ year (Wiltsee, 1998), which is about 20 to $25 \%$ of the amount of municipal sludge solids generated per capita.

Table 4-2 lists key assumptions pertaining to the SWPO commercial-scale economic analysis. SWPO gasification yields have been taken from GA's Phase I results for coprocessing sawdust slurries with ethanol auxiliary fuel. Actual SWPO gas yields for coprocessing mixtures of sewage sludge and grease have not been measured, but should be better than those obtained during Phase 1 because the organic portion of sewage sludge solids is less oxygenated than woody biomass, and grease has a higher $\mathrm{H}_{2}$ formation potential than does ethanol (see Table 25). Gas yields should be further increased once the Phase II process improvements are made.

TABLE 4-2. SWPO ECONOMIC ANALYSIS ASSUMPTIONS

\begin{tabular}{|l|c|c|}
\hline \multicolumn{1}{|c|}{ Description } & Assumption & Reference \\
\hline Plant size & $\begin{array}{c}40 \text { tpd total solids, 30 tons/day } \\
\text { organic sludge solids (not grease) }\end{array}$ & $\begin{array}{c}\text { Numerous plants of this size in the } \\
\text { US and worldwide }\end{array}$ \\
\hline Sludge solids credit & $\$ 0-300$ per dry ton & SDSU survey (Appendix D) \\
\hline Gasifier residence time & 20 seconds & 15 seconds for UHM, 1998a \\
\hline Trap grease credit & $\$ 0.08$ per gallon & Darling/Al Max telecons \\
\hline Steam credit & $\$ 3.50$ per MMBtu $(\approx 1000 \mathrm{lb})$ & Yeboah et al., 2002 \\
\hline Cost of liquid oxygen (LOX) & $\$ 0.04$ per pound & Vendor discussions \\
\hline Financing rate & Up to 20 years & $\begin{array}{c}\text { Current prime interest rate is below } \\
5 \%\end{array}$ \\
\hline Financing period & $\begin{array}{c}\text { City of San Diego methane } \\
\text { contract is a 20-yr term }\end{array}$ \\
\hline
\end{tabular}


The credit for accepting sewage sludge varies considerably between municipalities. GA's recent survey of POTWs throughout the U.S. shows a range of disposal costs from about $\$ 50$ 500 per ton (see Appendix D). GA has identified the nearby Encina municipal wastewater treatment plant as a potential reduced-scale SWPO demonstration site. This plant currently serves a population of about 250,000 and in 1997 was paying $\$ 120$ per dry ton to have their biosolids trucked away. They are currently paying $\$ 200$ per dry ton and expect prices to continue to rise. The Encina site processes about $40 \mathrm{tpd}$ of undigested sludge solids, the same size as the commercial-scale SWPO plant considered in the economic analysis. Numerous wastewater treatment plants the size of Encina exist across the US.

The grease trap credit of $\$ 0.08$ per gallon is derived from discussions with Darling International and Al-Max Sanitation in San Diego, and are typical costs for medium to large metropolitan areas. The credit is based on avoided costs for grease solidification and disposal. Darling charges restaurants $\$ 0.15-0.25$ per gallon to pick up their grease trap waste. The waste is 70 $75 \%$ water. To separate and solidify the grease, lime and polymer are mixed in to yield a sandlike precipitate. This precipitate is then landfilled. Separation, solidification and landfilling of the grease costs about $\$ 0.06-0.10$ per gallon of as-collected trap grease, including a landfill tipping fee of $\$ 42$ per ton plus a "special waste" surcharge of $\$ 50$ per truckload. This is equivalent to about $\$ 100 /$ ton on a water-free basis. Darling collects about 15,000 gallons of trap grease per day, and has about $40 \%$ of the San Diego market. Our discussions with Al-Max Sanitation confirmed that a grease trap credit of $\$ 0.08$ per gallon is reasonable. Al-Max stated that they would gladly pay $\$ 0.10$ per gallon for someone to accept the grease trap waste.

A number of economic analyses were performed for different SWPO plant sizes, sludge solids/grease ratios, sludge solids credits, and financing rates. Tables 10 through 12 provide details on the analysis of the selected commercial-scale SWPO plant installed cost and operating costs. Table 4-3 provides the capital cost for the case of 40 tpd of slurried asreceived sludge solids (30 tpd of organic sludge solids) coprocessed with trap grease. The ratio of grease to sludge is twice the amount necessary to raise the combined feeds to the final temperature of $650^{\circ} \mathrm{C}$, and half of the grease or its equivalent is oxidized and the other half is gasified. This is the case covered by the mass and energy balance in Table 3-2, where it can be seen that the plant is processing about as much grease $(0.49 \mathrm{~kg} / \mathrm{sec})$ as sludge solids $(0.42$ $\mathrm{kg} / \mathrm{sec}$ ). Table 4-4 shows the operating costs for this case while the plant capital expense is 
GA-C24239

TABLE 4-3. SWPO CAPITAL COST ESTIMATE FOR COMMERCIAL-SCALE PLANT

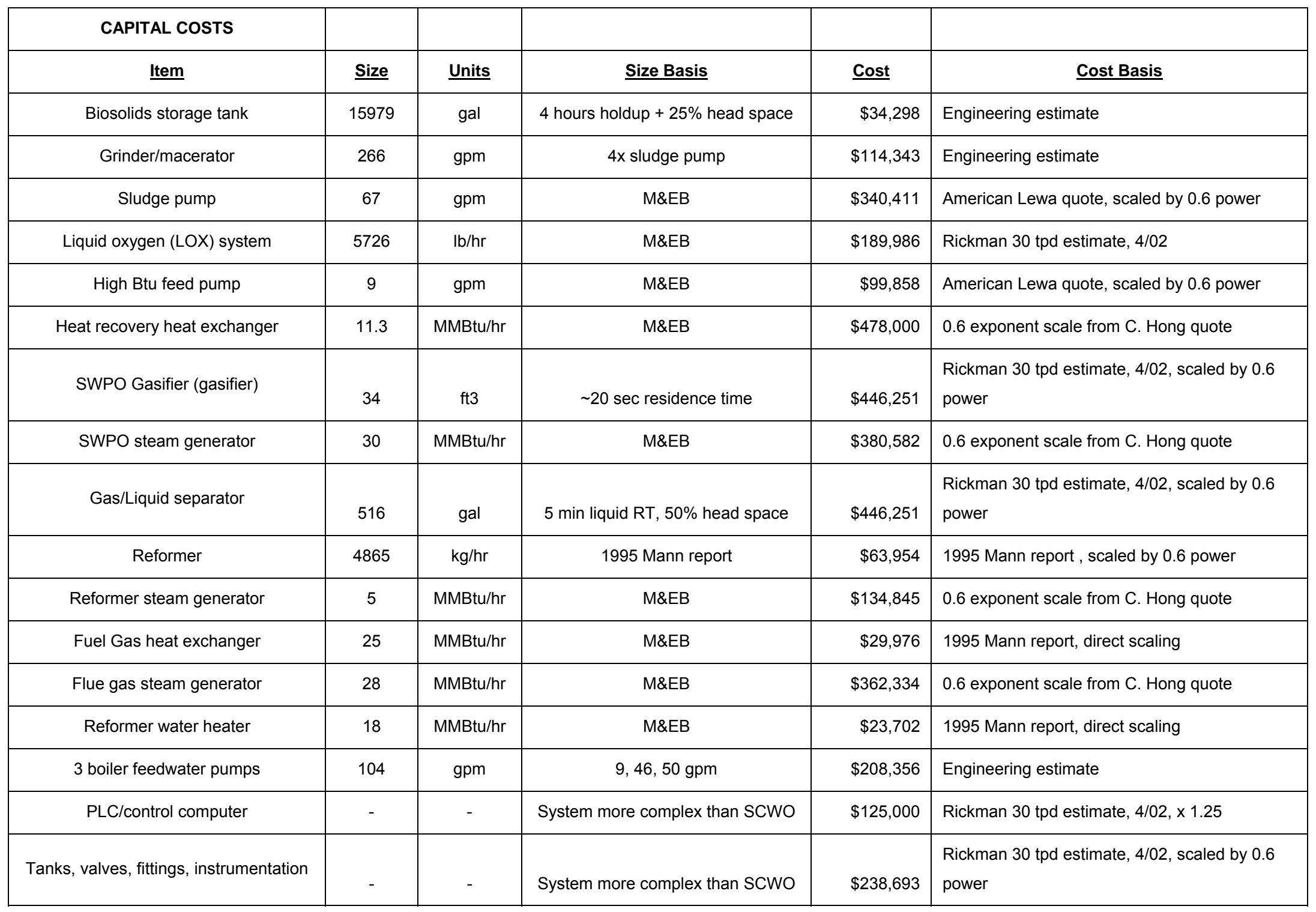


GA-C24239

\begin{tabular}{|c|c|c|c|c|c|}
\hline CAPITAL COSTS & & & & & \\
\hline$\underline{\text { Item }}$ & $\underline{\text { Size }}$ & $\underline{\text { Units }}$ & $\underline{\text { Size Basis }}$ & $\underline{\text { Cost }}$ & $\underline{\text { Cost Basis }}$ \\
\hline Skids & - & - & System more complex than SCWO & $\$ 103,779$ & $\begin{array}{l}\text { Rickman } 30 \text { tpd estimate, } 4 / 02 \text {, scaled by } 0.6 \\
\text { power }\end{array}$ \\
\hline Gas analyzers & - & - & $\mathrm{H} 2, \mathrm{CO}, \mathrm{CH} 4, \mathrm{CO} 2$ & $\$ 200,000$ & $2 \times \mathrm{ROK}$ \\
\hline Total equipment & & & & $\$ 4,233,800$ & \\
\hline Design/engineering & & & & $\$ 1,354,816$ & $32 \%$ of equipment \\
\hline Fabrication & & & System more complex than SCWO & $\$ 1,193,463$ & $\begin{array}{l}\text { Rickman } 30 \text { tpd estimate, } 4 / 02 \text {, scaled by } 0.6 \\
\text { power }\end{array}$ \\
\hline Facilities & & & & $\$ 423,000$ & 0.1 times major equipment cost \\
\hline Startup & & & System more complex than SCWO & $\$ 460,000$ & Rickman 30 tpd estimate, $4 / 02, \times 2$ \\
\hline $10 \%$ Contingency & & & & $\$ 766,508$ & Rickman 30 tpd estimate, 4/02 \\
\hline $15 \%$ Profit & & & & $\$ 1,149,762$ & Rickman 30 tpd estimate, 4/02 \\
\hline TOTAL INSTALLED COSTS & & & & $\$ 9,581,348$ & \\
\hline
\end{tabular}


GA-C24239

TABLE 4-4. INITIAL SWPO OPERATING COST ESTIMATE FOR COMMERCIAL SCALE PLANT

\begin{tabular}{|c|c|c|c|c|}
\hline \multicolumn{3}{|c|}{ OPERATING COST, \$/YR @ 330 ANNUAL OPERATING DAYS } & \multirow[b]{2}{*}{$\underline{\text { Cost }}$} & \multirow[b]{2}{*}{$\underline{\text { Cost Basis }}$} \\
\hline$\underline{\text { Item }}$ & Assumption & $\underline{\text { Units }}$ & & \\
\hline Labor & 6 operators & & $\$ 350,000$ & Rickman 30 tpd estimate, $4 / 02$ \\
\hline Oxygen & $\$ 0.04$ & per lb & $\$ 1,814,047$ & M\&EB \\
\hline Other utilities and chemicals, etc. & 2 & $\%$ of installed cost & $\$ 192,000$ & GA estimate \\
\hline Maintenance & 6 & $\%$ of installed cost & $\$ 574,881$ & GA 30 tpd estimate, $4 / 02$ \\
\hline Ash disposal & 42 & \$/bone dry ton & $\$ 138,600$ & San Diego landfill \\
\hline Capital recovery & 20 years at $12 \%$ interest & & $\$ 1,282,739$ & \\
\hline Grease credit & $\$ 0.08$ & per gallon & $\$(1,228,292)$ & Credit $=\$ 20 /$ wet ton $@ 8 \mathrm{lb} /$ gal \\
\hline Steam credit & 3.5 & per MMBtu & $\$(1,593,080)$ & 1200 psi steam if desired \\
\hline Sludge solids credit & 100 & $\$ /$ bone dry ton & $\$(1,320,000)$ & $1 / 2$ Encina disposal cost \\
\hline TOTAL & & & $\$ 210,896$ & \\
\hline Hydrogen kg/year & 653365 & & & \\
\hline Hydrogen GJ/year & 77358 & & & \\
\hline Hydrogen production cost, \$/GJ & 2.73 & & & \\
\hline
\end{tabular}


GA-C24239

TABLE 4-5. SWPO OPERATING COST ESTIMATE FOR COMMERCIAL SCALE PLANT FOLLOWING CAPITAL COST RECOVERY

\begin{tabular}{|c|c|c|c|c|}
\hline \multicolumn{3}{|c|}{ OPERATING COST, \$/YR @ 330 ANNUAL OPERATING DAYS } & \multirow[b]{2}{*}{$\underline{\text { Cost }}$} & \multirow[b]{2}{*}{ Cost Basis } \\
\hline$\underline{\text { Item }}$ & Assumption & $\underline{\text { Units }}$ & & \\
\hline Labor & 6 operators & & $\$ 350,000$ & Rickman 30 tpd estimate, 4/02 \\
\hline Oxygen & $\$ 0.04$ & per lb & $\$ 1,814,047$ & M\&EB \\
\hline Other utilities and chemicals, etc. & 2 & $\%$ of installed cost & $\$ 192,000$ & GA estimate \\
\hline Maintenance & 6 & $\%$ of installed cost & $\$ 574,881$ & GA 30 tpd estimate, 4/02 \\
\hline Ash disposal & 42 & $\$ /$ bone dry ton & $\$ 138,600$ & San Diego landfill \\
\hline Capital recovery & Paid off & & $\$ 0$ & \\
\hline Grease credit & $\$ 0.08$ & per gallon & $\$(1,228,292)$ & Credit $=\$ 20 /$ wet ton $@ 8 \mathrm{lb} /$ gal \\
\hline Steam credit & 3.5 & per MMBtu & $\$(1,593,080)$ & 1200 psi steam if desired \\
\hline Sludge solids credit & 0 & $\$ /$ bone dry ton & $\$ 0$ & \\
\hline TOTAL & & & $\$ 248,157$ & \\
\hline Hydrogen kg/year & 653365 & & & \\
\hline Hydrogen GJ/year & 77358 & & & \\
\hline Hydrogen production cost, \$/GJ & 3.21 & & & \\
\hline
\end{tabular}


being recovered. Hydrogen production cost is highly competitive, at $\$ 2.73 / \mathrm{GJ}$. Table $4-5$ shows the operating costs for a case in which the plant capital expense has been paid off. In this case the SSS can be processed for free while retaining a highly competitive hydrogen production cost of $\$ 3.21 / G J$. The detailed cost analysis in Tables 10-12 corresponds to a realistic commercialscale plant size, with performance and financing parameters that can be applied to numerous sites throughout the U.S.

For a plant processing 40 tpd of sewage sludge solids, Figure 4-2 shows how the production cost (or alternatively, the required breakeven selling price) of the hydrogen produced varies with sludge solids credit, grease ratio, and plant financing. For the " $1 \mathrm{x}$ grease" case the amount of grease supplied equals the amount necessary to raise the combined feeds to the final temperature of $650^{\circ} \mathrm{C}$ and all of the grease or its equivalent is completely oxidized to $\mathrm{H} 2 \mathrm{O}$ and CO2. The " $2 x$ grease" case has twice this amount of grease, as mentioned above, and the " $3 x$ grease" case has three times this amount of grease. Financing rates of up to $12 \%$ have been used in view of the novel nature of the technology. The legend lists the financing rates in order of payment amount, i.e., 5 years at $12 \%$ requires the highest payment while 20 years at $6 \%$ requires the lowest payment. For each grease level, the rightmost lines correspond to the highest capital payments while the leftmost lines correspond to the lowest capital payments. It is important to note that the customers for these initial plants will be municipalities as opposed to commercial entities. Discussions with several municipalities suggest that very low financing rates may be possible, with long-term loan guarantees provided by the municipalities. Figure 42 shows that there is a significant subset of conditions under which hydrogen can have a highly competitive production cost (or breakeven selling price) of $\$ 5 / G J$ or less. Figure 4-3 shows how the hydrogen production cost or breakeven selling price is reduced once the capital cost is paid off. There is now only a single line for each grease level as the alternative financing terms are no longer relevant. For $3 x$ grease, a hydrogen production cost of about $\$ 3 / G \mathrm{~J}$ can actually support a sludge solids payment to the supplier of about $\$ 75 / \mathrm{bdt}$.

Ultimately, as distributed production of hydrogen becomes commercial, credits for sludge solids and grease may decrease and eventually become valuable waste products that can be sold at a profit. Thus, eventually, reduced credits or even payments for sludge and grease (rather than credits) may have to be offset by lower SWPO capital and operating costs. 


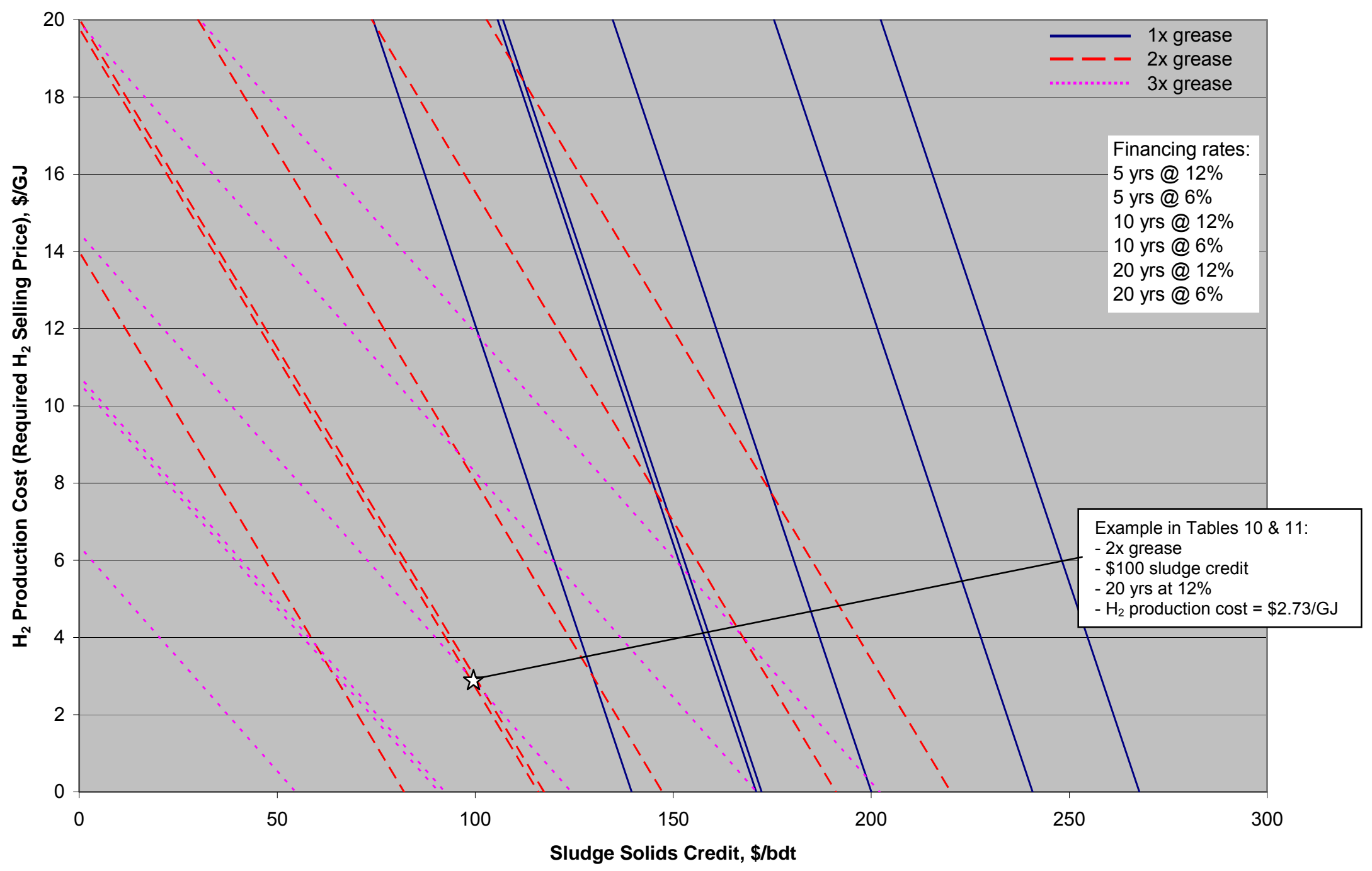

Figure 4-2. $\mathrm{H}_{2}$ production cost for SWPO of $12 \mathrm{wt} \%$ sewage sludge coprocessed with grease auxiliary fuel. 


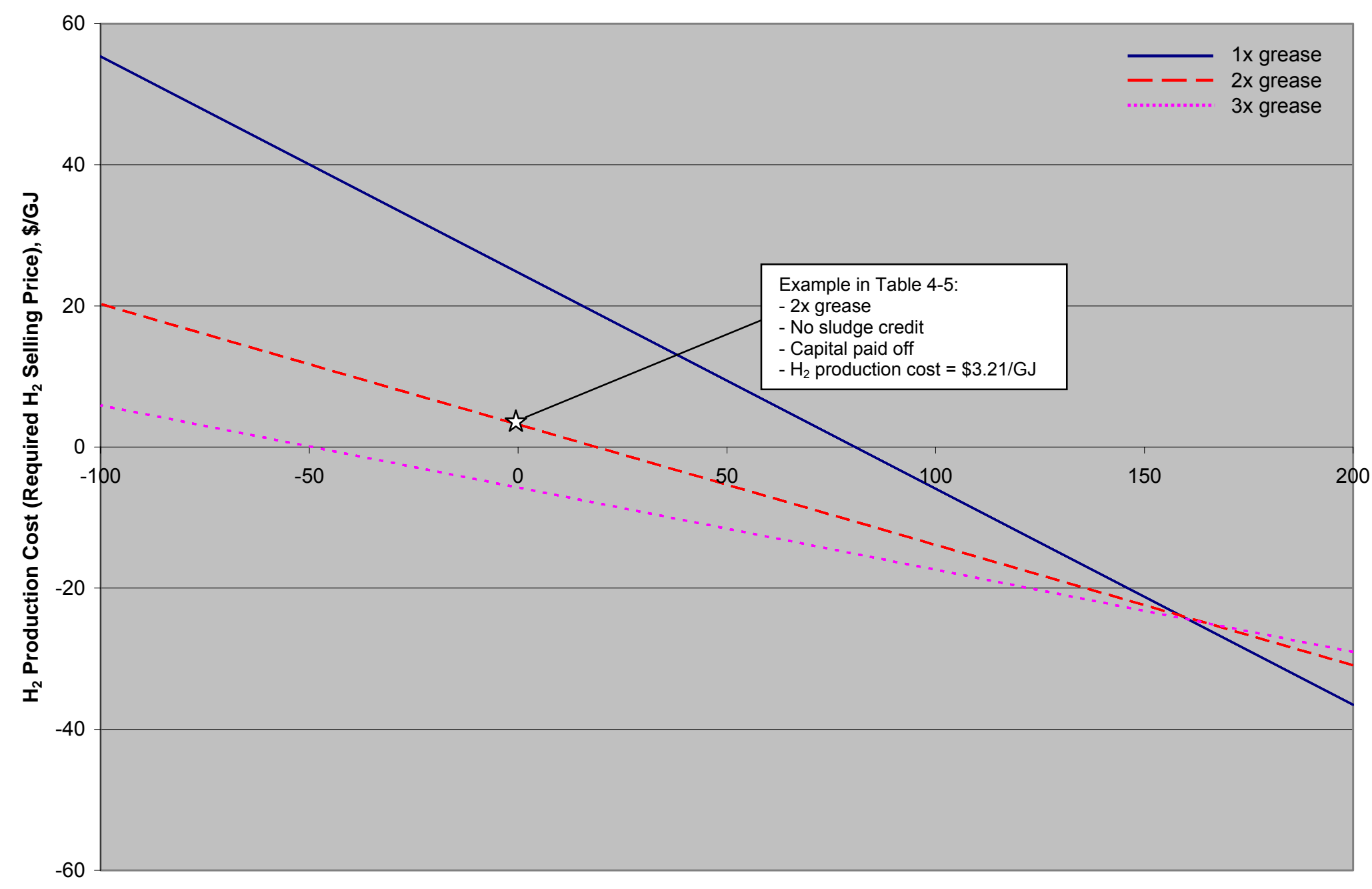

Sludge Solids Credit, \$/bdt

Figure 4-3. $\mathrm{H}_{2}$ production cost for SWPO of $12 \mathrm{wt} \%$ sewage sludge coprocessed with grease auxiliary fuel following capital cost recovery. 
As SWPO distributed hydrogen production plants are installed at wastewater treatment plants, the sludge and grease credits may eventually decrease as the wastes begin to acquire value in the competitive marketplace. At this point, capital, operating and financing cost reductions, and/or alternative negative value feedstocks (manure, MSW) will be needed to maintain low hydrogen production costs. But by this time SWPO plants will be proven, and capital, operating and financing costs are expected to decrease sufficiently to offset the reduced sludge and grease credits.

While the economics of relatively small-scale SWPO hydrogen distributed production plants appear to be competitive with alternate hydrogen sources, a multi-phase development and demonstration program is needed before the technology is ready for commercialization. The following sections describe the Phase II through Phase IV development and demonstration activities.

\subsection{PHASE II - TECHNOLOGY DEVELOPMENT: $(1 / 03$ - 12/04)}

During Phase II, further development of SWPO technology will be performed to resolve knowledge gaps, and to define performance requirements and system interfaces for Phase III, System Integration and Design. The technical issues requiring further development were previously discussed in Sections 3 and 4. Testing of key SWPO subsystem components (e.g. feed mixing and pumping, feed preheating, feed injection and gasification, tar/char/ash handling, heat recovery, and pressure letdown) will be performed. This phase will involve longer duration tests than previously performed, with a target of 100 hours of continuous operation with the key target feed, sewage sludge plus grease trap waste, to demonstrate longterm operability. As part of the pilot test program, heat exchanger reliability will be monitored and measurements and observations regarding materials of construction will be carried out. Disposition and behavior of ash and char within the system will also be determined. As time and budget allow optional features (e.g. alternate feedstocks and a methane reformer) will be tested.

Task 1 - Develop Advanced SWPO Gasification System. Using the existing GA pilot plant, tests will be performed to demonstrate improved gasifier and heat exchanger designs and ability to handle the target sewage sludge feedstock coprocessed with grease trap waste. Time and budget permitting, tests will be performed with alternate feedstocks, alternate feed introduction schemes, and alternate gasifier designs. Specific subtasks are planned to:

1. Improve Pilot Plant instrumentation needed to improve mass balance and yield calculations.

2. Reduce residual char formation and improve gasification yields by improving mixing and increasing residence time at temperature.

3. Verify Phase I gasification yields with more representative feeds of 1) SSS + trap grease, 2) micronized wood + trap grease, and 3) SSS or micronized wood + micronized plastic or tire rubber.

4. Verify that the rate of char/ash buildup in the gasifier and heat-recovery heat exchanger and associated maintenance requirements are acceptable. 


\section{Deleted due to proprietary content.}

6. Deleted due to proprietary content.

7. Demonstrate a methane reformer integrated with the SWPO system (optional).

\section{Task 2 - Systematize and Test Advanced SWPO Gasification System.}

Once the installation of the advanced SWPO gasification system additions and modifications is complete, systemization of the integrated system will begin under Task 2 . Systemization will consist of a step-wise startup and automation of the integrated system with representative feeds. Modifications to instrumentation and controls will be made as appropriate to assure robust, long-term operability.

Once systemization is complete, one or more long-term operability tests will be performed with representative feeds similar to those used in Task 1 . Reliability and maintenance data will be recorded, along with the gasification data and system operating parameters. Test duration will be $50-100 \mathrm{hrs}$, with liquid and gas effluent samples taken at several intervals throughout the tests.

\section{Task 3 - Perform Special Studies and Update SWPO Development Plan}

In parallel with the Task 1 and 2 work, several studies will be performed to accumulate relevant technical and economic data for target SWPO feedstocks and other biomass-to-energy systems for comparison to the SWPO system.

\section{Feedstock Supply Assessment for Advanced SWPO Gasification Systems}

A feedstock supply assessment will be performed to estimate the quantities and associated costs of selected biomass and auxiliary fuels that are available for the advanced SWPO gasification system, including sewage sludge (SS), sorted MSW such as wood, plastic and rubber, grease trap wastes, animal wastes, and potentially other (not yet identified) opportunity feeds. The focus will be primarily on feedstocks near metropolitan centers addressing supplies at various population densities.

2. Preliminary Economic and Market Analyses for Advanced SWPO Gasification Systems

A preliminary economic analysis will be performed to evaluate the life cycle cost of the selected advanced SWPO hydrogen gasification system. The analysis will include estimates and forecasts of biomass and auxiliary fuel costs, system capital, operating and maintenance costs, potential credits, net hydrogen production costs over time and/or by-product revenue streams. A preliminary market analysis will be performed to better define the potential for deployment of advanced SWPO gasification systems. Initial deployment of SCWO systems for waste disposal will be assessed as an initial entry point into the municipal sludge market. National and regional markets may be considered, although emphasis will be placed on California as an ideal representative market for the proposed approach.

\section{Assessment of Biomass Gasifiers}

A survey and assessment of biomass gasifiers will be performed to establish a comparative database for SWPO. The assessment will determine what gasifiers are currently or recently in 
operation, and will tabulate key parameters, e.g. T, P, feedstock, steam/feed ratio, hydrogen production, char formation, etc. The purpose of the assessment is to assemble performance data in a consistent format that will allow comparative analysis of different gasifiers.

\section{Assessment of Transportation-Grade Ethanol Life Cycle Cost}

Transportation-grade ethanol has become a thriving business in recent years in the United States. The corn-to-ethanol life-cycle-cost (LCC) is useful as a comparative model for other feedstocks and processing methods. An assessment of the corn-to-ethanol LCC will be performed to identify common cost drivers for other feedstocks, and to define barriers to the development of biomass gasification and hydrogen production using SWPO.

\section{Update of SWPO Development Plan}

The results of these special studies will be used to update the SWPO development plan presented herein. The technical information from Tasks 1 and 2 will also be used in revising the development plan, and in defining the requirements for Phase III.

At the conclusion of Phase II, the SWPO PFD, M\&EBs, and system interfaces (e.g., sewage sludge and grease trap waste supply, and separation, storage and disposition of $\mathrm{H}_{2}$ product) will have been defined for the Phase III effort.

\subsection{PHASE III - SYSTEM INTEGRATION AND DESIGN: $(1 / 05-12 / 05)$}

Phase III, System Integration and Design, involves detailed design and long-lead fabrication of dedicated equipment for the 5 tpd reduced-scale SWPO demonstration system for Phase IV, including industrial $\mathrm{H}_{2}$ separation and storage systems. The piping and instrumentation diagram will be prepared and the process control logic developed. Equipment drawings and specifications will be prepared, long-lead equipment procured, and assembly begun. Supporting tasks, including a safety evaluation, RAM studies, and required permitting activities will be carried out. Economic estimates will also be revised to be consistent with the experience of the Phase II program to ensure that the technology continues to meet the criterion of economic viability.

\subsection{PHASE IV - REDUCED-SCALE DEMONSTRATION SYSTEM: (1/06 - 12/08)}

In Phase IV a 5 tpd reduced-scale version of the 40 tpd commercial-scale SWPO plant will be assembled, systemized, and then demonstrated. The reduced-scale unit will process about 5 tpd of sewage sludge solids, approximately one-eighth the size of the commercial-scale (40 tpd) for which viable economics have been projected. Figure 4-4 shows a conceptual layout of the 5 tpd system. The 5 tpd SWPO system will be based on an existing commercial SCWO system designed and built by GA. A likely site for the reduced-scale demonstration is the Encina wastewater treatment plant located near GA. In a visit to the Encina plant in October 2002, potential locations for an initial SWPO demonstration plant (about 5 tpd capacity) were discussed. Figure 4-5 shows the Encina sludge dewatering building, while Figure 4-6 shows one of the two interior locations that are potentially available in this building for the SWPO system. 


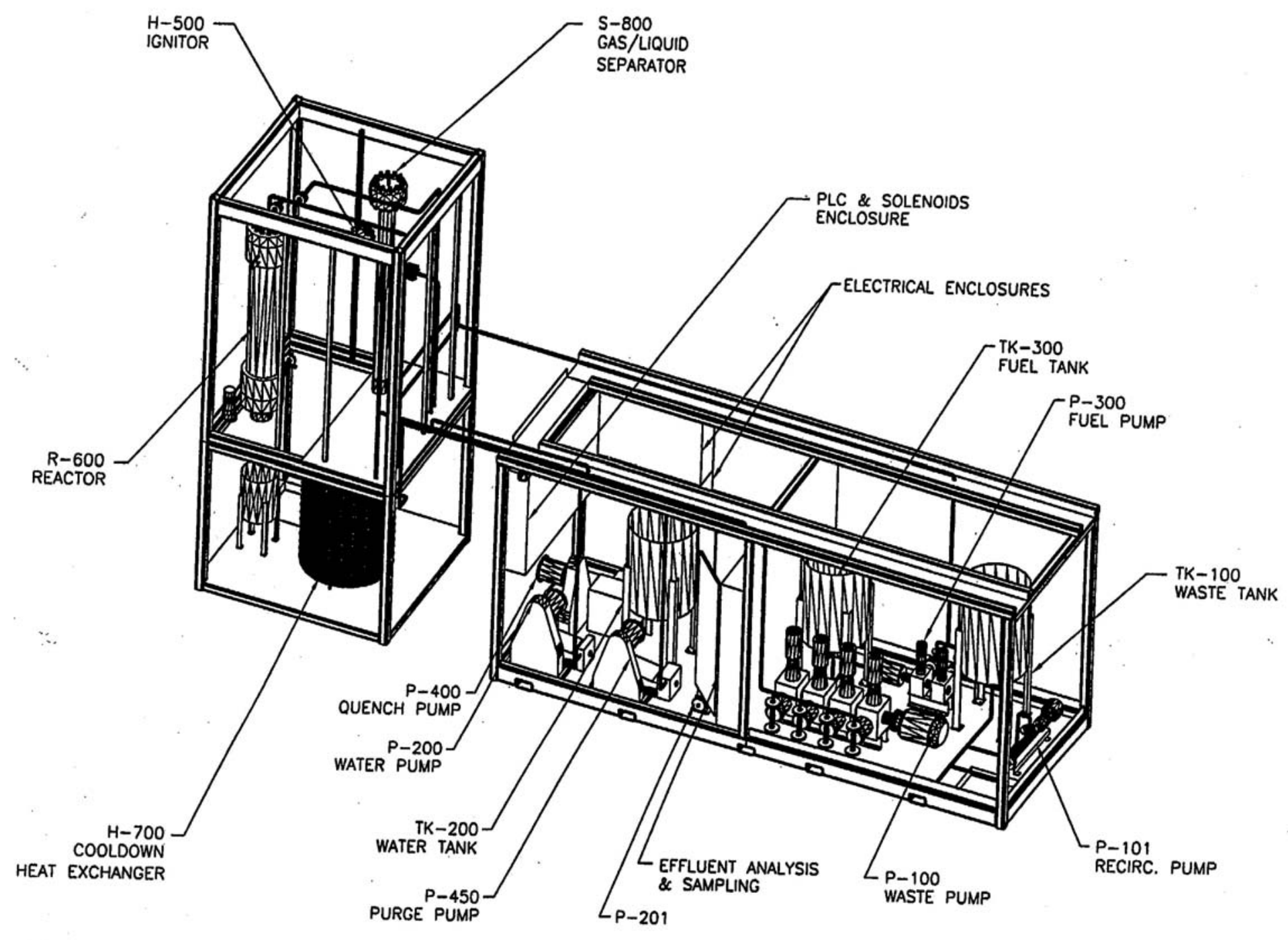

Figure 4-4. SWPO reduced-scale system for $5 \mathrm{tpd}$ of sludge solids coprocessed with waste grease. 


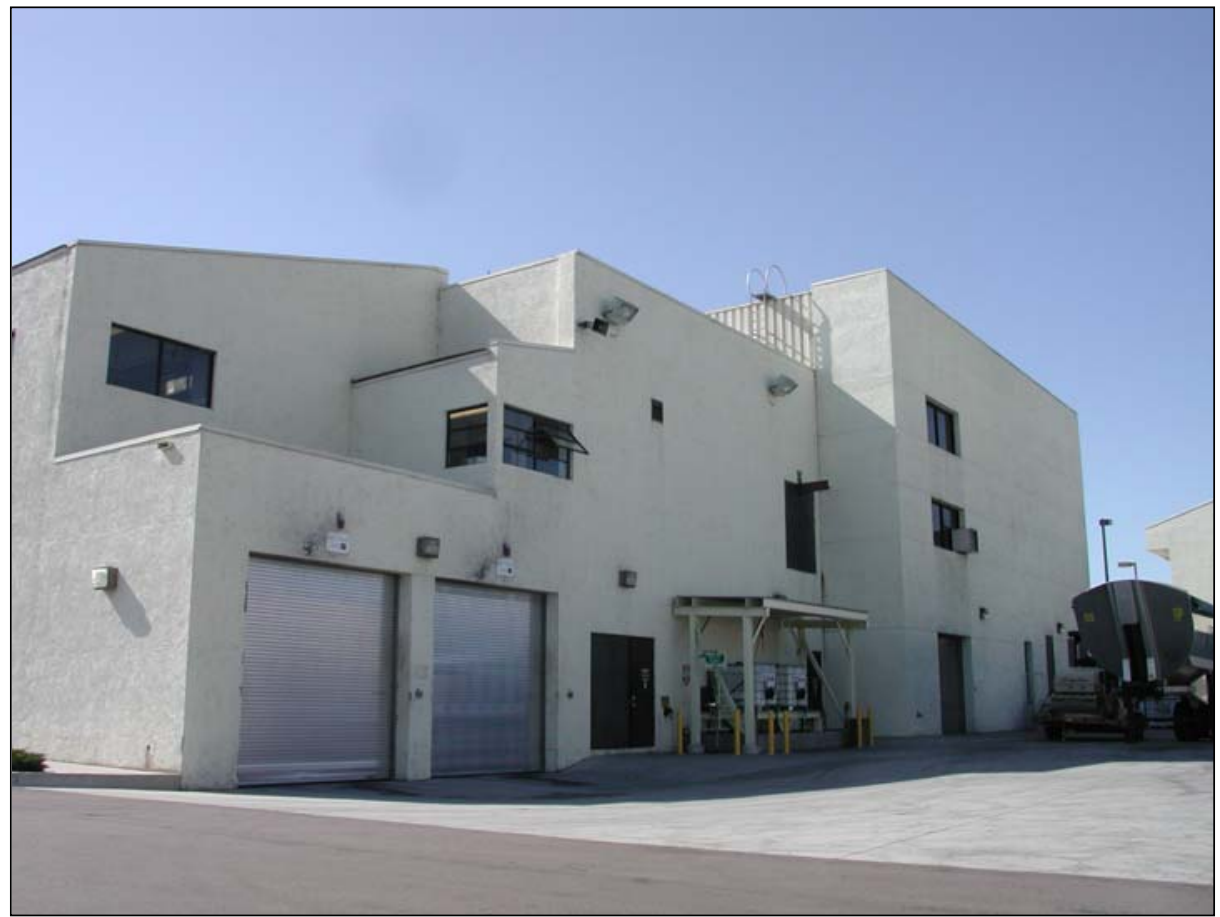

Figure 4-5. Encina sludge dewatering building, a potential SWPO reduced-scale demonstration site.

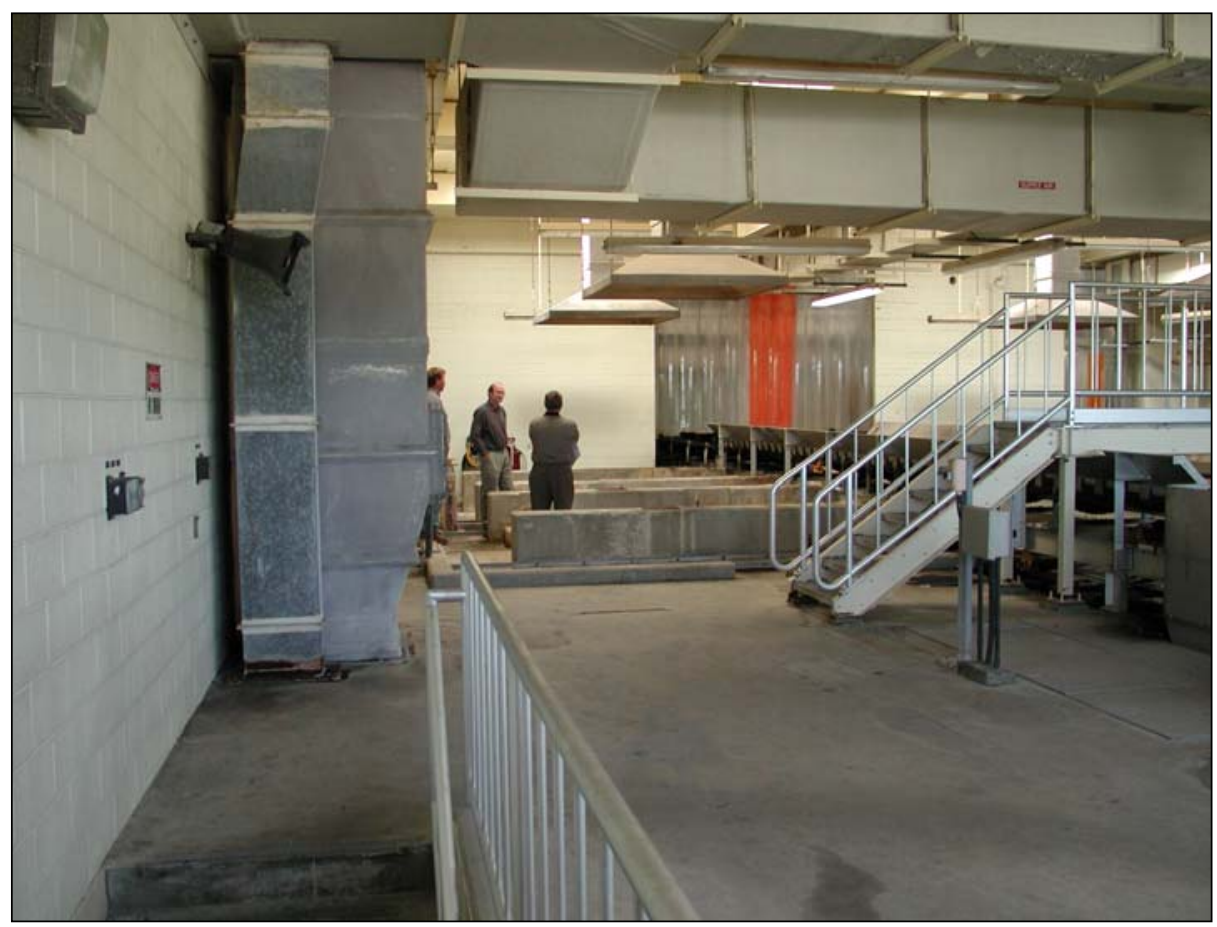

Figure 4-6. Encina sludge conveyor room is available for a SWPO reduced-scale demonstration unit. 
The reduced-scale demonstration system will undergo systemization and shakedown testing with progressively more complex feeds. Integrated system testing with sludge solids and waste grease will then be carried out over a period of several months. A successful demonstration at this scale should be sufficient to attract municipal/industrial partners for a follow-on commercialscale demonstration at a larger wastewater treatment site.

\section{5. $\quad$ BUSINESS PLAN DEVELOPMENT}

A business plan has been developed for the commercialization of SWPO distributed hydrogen production by coprocessing of sewage sludge solids and waste grease. Three primary sources of data have been used in developing the plan: (1) costs and other information gathered from wastewater treatment facility operators and equipment suppliers; (2) GA's related experience with SCWO of sewage sludge and hazardous wastes; and (3) economic analysis of the commercial-scale SWPO system presented in Section 5.1. This section describes how the Business Plan was developed. The Business Plan itself is included in Appendix C. The SWPO business plan was developed along parallel lines used by Mann (1995) to evaluate the BCL gasifier. Throughout, the objective has been to identify engineering and economic considerations needed to reduce capital and operating costs sufficiently to support hydrogen production costs well within the competitive market rates for hydrogen of $\$ 5$ to $\$ 14$ per GJ targeted by the DOE Hydrogen program.

\subsubsection{Methodology and Assumptions}

Development of the plan incorporated a series of steps and associated assumptions that progressed from the definition of the optimum size for a commercial SWPO unit through definition of the marketing and financial plans.

Step 1 - Define Optimum Size of Commercial-Scale SWPO System. Sewage sludge-derived solids are produced at all wastewater treatment facilities in the U.S. As part of a market assessment for SCWO, GA sponsored a national survey of municipal wastewater treatment plants carried out by the San Diego State University. The results suggest that there are several hundred plants the size of Encina or larger across the U.S. Thus a plant the size of Encina - 40 tpd total solids or 30 tpd of sewage sludge organics - would be appropriate for a large number of cities or water districts. This size is also a credible factor of eight scale-up of the 5 tpd reduced-scale demonstration system planned for Phase IV.

Step 2 - Define Capital and Operating Costs of Commercial-Scale SWPO System. Based on the 40 tpd size defined in Step 1, capital and operating costs were generated (see Section 5.1). M\&EBs for the target plant size were prepared (see Table 3-1) to permit sizing of system components and to define operating personnel and utility requirements. Capital costs were obtained by scaling costs for SCWO or other high pressure, high temperature systems and by estimating average labor and utility rates.

\section{Step 3 - Compare Commercial-Scale SWPO System Costs to Alternate Systems for} Hydrogen Generation and Use. Once capital and operating costs were obtained, SWPO hydrogen production costs were compared to the benchmark of $\$ 5-\$ 14 / G J$, the economic sale price range for hydrogen (Mann et al., 1996). The negative cost of sludge solids disposal 
provides a credit that is an important driver in the economic analysis showing that SWPO of sludge solids with waste grease can produce hydrogen at a cost that is competitive with other methods of hydrogen production.

Step 4 - Discuss SWPO Commercial-Scale System with Regional Wastewater Treatment Facilities. The commercial-scale SWPO system was discussed with Encina personnel to obtain their perspective and how they and other wastewater treatment facilities might respond to the proposed method of sludge solids disposal and associated cost savings. Follow-up with other wastewater treatment plants is planned. While Encina has an existing treatment system for sewage sludge, disposal of sludge solids is a significant operating cost, most of which could be avoided with SWPO. This is the initial thrust for deployment of SWPO at wastewater treatment plants. Also of future interest to wastewater plant operators is the potential to discontinue use of some of the treatment equipment associated with sludge treatment. The current treatment systems incorporate large tanks, numerous pumps and valves, and extensive piping for anaerobic digestion of sewage sludge. Avoiding this treatment step, and the subsequent sludge dewatering step was thought to be a long-term advantage for incorporation of SWPO into the plant design. However, initially, SWPO should be introduced as simply an alternative primary and secondary sludge treatment process using a small portion of the treatment plant's capacity. For Encina, with a capacity of 40 tpd of sludge solids, a 5 tpd reduced-scale SWPO demonstration would not upset the normal operations of the site while the demonstration is underway.

The initial 40 tpd commercial-scale SWPO plants should be sited at much larger host sites, such as the San Diego Metropolitan Biosolids Center (MBC) or the Orange County Wastewater Treatment Facility. The MBC has a mixed sludge solids capacity of about $110 \mathrm{tpd}$, and could accommodate a $40 \mathrm{tpd}$ commercial-scale demonstration without upsetting normal operations. Once commercial-scale SWPO systems have been successfully demonstrated at large wastewater treatment plants, they can be marketed to facilities that have sludge capacities closely matching the SWPO system capacity.

Step 5 - Update Demonstration Program and Related Funding Requirements for Phases II thru IV of the Program. Having determined that SWPO hydrogen production is cost effective and that a potential market may exist for systems at a large number of wastewater treatment facilities, the technology development, technology validation, and reduced-scale demonstration planned in Phases II through IV of the DOE program have been updated, and the associated funding requirements have been revised (see Appendix $\mathrm{C}$ ).

Step 6 - Prepare Financial and Long-Range Marketing Plans. Phases II through IV will be followed by development and demonstration of a commercial-scale SWPO system at a regional wastewater treatment facility. The facility will likely be one of the large municipal wastewater treatment plants in southern California producing 100-200 tpd biosolids. Ideally, a first of a kind SWPO system rated at $40 \mathrm{tpd}$ would not impact the overall operations of the facility. The demonstration will include a year or more of on-site operation to provide first-hand operating experience by facility personnel. Successful demonstration will be followed by design of a standard 40 tpd SWPO system and its commercial sale to wastewater treatment authorities. The financial requirements for the reduced-scale and commercial systems were estimated based on this scenario. 
Step 7 - Prepare the Business Plan. Input from Steps 1 through 6 above was integrated into the business plan encompassing SWPO development through reduced-scale demonstration, and preparations for commercial-scale system development and sales.

Please refer to Appendix $\mathrm{C}$ for the complete Business Plan. 


\section{CONCLUSION}

A versatile pilot plant for exploring gasification in supercritical water has been established at GA's facilities in San Diego. Phase I testing of the SWPO process progressed to coprocessing of wood and ethanol auxiliary fuel mixtures resulting in gasification efficiencies of about $90 \%$, comparable to those found in prior laboratory-scale work carried out at the University of Hawaii. Unlike the UHM work that was indirectly heated and used catalysts, the GA process is heated mainly by partial oxidation of the feed without a catalyst bed that can cause plugging. As in the UHM work, a significant amount of the hydrogen found in the gas phase products is derived from the water/steam matrix, another benefit of the supercritical regime.

Phase I testing provided the following key findings in the development of SWPO technology:

1. Pumping tests indicate that a slurry feed concentration of about $12 \mathrm{wt} \%$ biomass solids is a conservative maximum. Composted municipal solid waste mixed with sewage sludge solids was pumped at about $30 \mathrm{wt} \%$ during Phase I, and other observations suggest that $14 \mathrm{wt} \%$ sawdust slurries should be pumpable. GA has previously had good success at pumping sewage sludge at solids contents of 10-14 wt\%, while literature sources claim that $15 \mathrm{wt} \%$ is pumpable. Economic projections utilizing 12 $\mathrm{wt} \%$ thus represent a conservative minimum. If higher concentrations can be pumped, as appears likely, SWPO economics will be improved.

2. Feed preheat should be limited to $260^{\circ} \mathrm{C}$ to avoid char formation and plugging. Higher preheat temperatures may be possible with certain feedstocks or with improved heat exchanger designs, but these have not yet been demonstrated by GA.

3. Due to the limitations on feed slurry biomass concentration and feed preheat temperature, a high heating value waste must be coprocessed with the biomass in order to attain the desired gasifier temperature and still have sufficient feedstock for gasification. This is essentially the approach that evolved during Phase I testing, although the high heating value feed was the model compound ethanol as opposed to a waste material. Suitable high-heating value wastes are plastics, rubber, or trap grease.

4. Use a vessel-type gasifier as opposed to a pipe-type gasifier to allow higher gasifier operating temperatures and heat conservation.

5. Use a catalyst-free gasifier to enable long-term operation with dirty feed materials without plugging.

6. Use a high-energy nozzle giving high dispersion of the incoming feed to improve mixing and attain high gasification yields.

7. Use a methane-steam reformer on the clean SWPO product gas. 
The Phase I results indicate that a practical means to overcome limitations on biomass slurry feed concentration and preheat temperature is to coprocess an auxiliary high heating value material. SWPO coprocessing of two high-water content wastes, partially dewatered sewage sludge and trap grease, yields a scenario for the production of hydrogen at highly competitive prices. It is estimated that there are hundreds if not thousands of potential sites for this technology across the US and worldwide. Our economic analysis indicates that a broad range of conditions exist for which SWPO can be used to produce hydrogen at competitive prices. Key economic factors include:

1. Biomass credit - Sewage sludge-derived solids are particularly desirable as they generally have a negative value of $\$ 200 /$ bdt and higher, are readily available and sustainable as a distributed feedstock, and require minimal size reduction. GA has successfully demonstrated pilot-scale gasification of sewage sludge in prior work for the DOE. Other biomass feedstocks such as waste wood or paper products are also feasible at somewhat less favorable economic projections.

2. High heating value waste cost or credit - Grease trap waste is particularly desirable as a cofeed with sewage sludge solids (SSS) as it generally has a negative value similar to SSS and is as readily available and sustainable as SSS. Avoided costs for disposal of grease trap wastes is about $\$ 100$ per ton of concentrated grease ( $\$ 0.08$ per wet gallon) or higher. Other high heating value wastes such as waste plastic or rubber and coal are also feasible as cofeeds at somewhat less favorable economic projections.

3. Steam credit - Steam credit is a significant additional offset of operating costs. Much of the steam can be available at 1200 psi if desired.

4. Capital financing rate and term - Particularly favorable financing terms are expected as the targeted customers are municipalities as opposed to commercial entities. Low interest rate 20-year financing has been used for similar municipal projects in San Diego and elsewhere.

5. Ratio of high heating value waste to biomass solids - Higher ratios of high heating value waste lead to a higher proportion of hydrogen production for a given amount of biomass solids processed, further improving the economic projections.

6. Plant size - A plant treating 40 tpd of SSS is economically competitive over a broad range of conditions. In the U.S. there are hundreds of plants of this capacity, serving populations of about 200,000 people.

The economics for 40 tpd SSS plants augmented with grease trap waste are favorable over a significant range of cost parameters such as SSS credit and capital financing. Hydrogen production costs for SWPO plants of this size are projected to be about $\$ 3 / \mathrm{GJ}$ or less. Economics may be further improved by future developments such as pumping of higher solids content sludges and improved gasifier nozzle designs to reduce char and improve hydrogen yields. The easiest market entry for SWPO is expected to be sales to municipal wastewater treatment plants for use with sewage sludge in conjunction with trap grease, as both of these wastes are ubiquitous and have reasonably well-defined negative value (i.e., the process can 
take credit for avoidance of well-defined disposal costs for these streams). Additionally, waste grease is frequently recovered at municipal wastewater treatment plants where it is already contaminated with sewage.

SWPO should also be favorable to other market applications in which low or negative value, high water content biomass is available in conjunction with a low or negative value fuel material. For biomass slurries primary candidates are sewage sludge, manure sludge, and shredded and/or composted organic municipal solid waste (MSW) slurries. For the high heating value stream primary candidates are trap grease, waste plastic or rubber slurries, and coal or coke slurries.

Phase II of the SWPO program will be focused on process improvement scoping tests followed by design, installation and extended duration testing of an advanced SWPO system using the existing GA pilot plant, which has a sludge solids capacity of about $0.1 \mathrm{tpd}$. Tests of at least 100 hours duration using sludge solids and waste grease as simultaneous feedstocks are a primary objective. Phases III and IV of the SWPO program are directed toward establishing a dedicated 5 tpd reduced-scale plant at a location such as the Encina municipal wastewater treatment plant. Subsequent to this reduced-scale demonstration, the technology will be ready for the commercial-scale, 40 tpd demonstration.

While there are clearly technical challenges that must still be addressed, the proven capability of SWPO to process wet, dirty feedstocks represents an outstanding opportunity to further the dual goals of developing a hydrogen economy and practicing environmentally sound waste disposal. It may well represent one of the few scenarios in which hydrogen can be produced economically from biomass at a relatively small scale. SWPO could thus play a pivotal role in the proliferation of hydrogen generation technology and significantly advance the inevitable transition to a hydrogen economy. 


\section{REFERENCES}

1. Bastian, R.K., "The Biosolids (Sludge) Treatment, Beneficial Use, and Disposal Situation in the USA", European Water Pollution Control, 7:62-79, 1997.

2. Blosser, R.O. and R.A. Miner, "Sludge Handling and Disposal Practices in the U.S. Pulp and Paper Industry", Environmental Protection in the 90's EUCEPA Symposium, Helsinki, 1986.

3. Buelow, S.J., R.B. Dyer, C.K. Rofer, J.H. Atencio and J.D. Wander, "Destruction of Propellant Components in Supercritical Water", Los Alamos National Laboratory paper no. LA-UR-90-1338, 1990.

4. Craig, K.R. and M.K. Mann, "Cost and Performance Analysis of Biomass-Based Integrated Gasification Combined -Cycle (BIGCC) Power Systems", National Renewable Energy Laboratory report DE96013105, 1996.

5. Czernik, S., R. French, C. Feik, and E. Chornet, "Hydrogen from Biomass via Fast Pyrolysis/Catalytic Steam Reforming Process", Proceedings of the U.S. DOE Hydrogen Program Review, 1999.

6. Czernik, S., R. French, C. Feik, and E. Chornet, "Production of Hydrogen from PostConsumer Wastes", Proceedings of the U.S. DOE Hydrogen Program Review, Golden, CO, May 6-8, 2002.

7. European Commission, "Disposal and Recycling Routes for Sewage Sludge", October 23, 2001.

8. Evans, R., S. Czernik, E. Chornet, C. Feik, and S. Phillips, "Engineering Scale Up of Renewable Hydrogen Production by Catalytic Steam Reforming of Peanut Shells Pyrolysis Products", Proceedings of the U.S. DOE Hydrogen Program Review, 2001.

9. General Atomics, "Sewage Sludge Gasification in Supercritical Water", Final Report, U.S. DOE Cooperative Agreement No. DE-FC36-97GO10216, 1997.

10. General Atomics, "Supercritical Water Oxidation Treatability Testing of PCB-Contaminated Sewage Sludge”, GA Document No. 2746901/A, December 1998.

11. General Atomics "Assembled Chemical Weapons Assessment (ACWA) Draft Test Technical Report," GA Document No. 129300/0, June 30, 1999.

12. General Atomics, "Update on Hydrothermal Oxidation Developments on DARPA/ONR and Air Force Projects at General Atomics", J.P. Elliott, D.A. Hazlebeck, D.W. Ordway, A.J. Roberts, M.H. Spritzer, J.A. Hurley and S. A. Rising Incineration and Thermal Treatment Technologies Conference, Portland, OR, 2000.

13. General Atomics, "Supercritical Water Partial Oxidation", G.T. Hong and M.H. Spritzer Proceedings of the U.S. DOE Hydrogen Program Review, Golden, CO, May 6-8, 2002. 
14. Griffith, J.W., "The Use of Hydrothermal Oxidation in the Treatment of Municipal Wastewater Sludge", presented at the Incineration and Thermal Treatment Technologies Conference, Portland, OR, 2000.

15. Griffith, J.W., W.T. Wofford and J.R. Griffith, "Apparatus for Oxidizing Undigested Wastewater Sludges”, U.S. Pat. No. 5,888,389, 1999.

16. Hong, G.T., "Process for Oxidation of Materials in Water at Supercritical Temperatures and Subcritical Pressures", U.S. Pat. No. 5,106,513, 1992.

17. Hong, G.T., B. Borchers, S. Pisharody and J. Fisher, "A Supercritical Water Oxidation Unit for Treating Waste Biomass", Paper No. 961560, Society of Automotive Engineers, 26th International Conference on Environmental Systems, 1996.

18. Johnston, J.B., R.E. Hannah, V.L. Cunningham, B.P. Dagy, F.J. Sturm and R.M. Kelly, "Destruction of Pharmaceutical and Biopharmaceutical Wastes by the Modar Supercritical Water Oxidation Process", Biotechnology, 6:1423-1427, 1988.

19. Katofsky, R.E., The Production of Fluid Fuels From Biomass, Princeton University Center for Energy and Environmental Studies Report No. 279, 1993.

20. Lin, S.Y., Y. Suzuki, H. Hatano and M. Harada, "A New Method (HyPr-RING) for Producing Hydrogen From Coals", in Prospects for Coal Science in the 21st Century, pp. 475-478, B.Q. Li and Z.Y. Liu eds., Shanxi Science and Technology, Taiyun, China, 1999a.

21. Lin, S.Y., Y. Suzuki, H. Hatano and M. Harada, "The Concept of a New High Efficiency and Clean Coal Utilization Process (HyPr-RING)", in Prospects for Coal Science in the 21st Century, pp. 1437-1440, B.Q. Li and Z.Y. Liu eds., Shanxi Science and Technology, Taiyun, China, 1999b.

22. Mann M.K., P.L. Spath and K. Kadam, "Technoeconomic Analysis of Renewable Hydrogen Production, Storage, and Detection Systems", Proceedings of the U.S. DOE Hydrogen Program Review, Miami, FL, May 1-2, 1996.

23. Mann, M.K., "Technical and Economic Assessment of Producing Hydrogen by Reforming Syngas from the Battelle Indirectly Heated Biomass Gasifier", NREL/TP-431-8143, August, 1995.

24. Modell, M., R.C. Reid and S.I. Amin, "Gasification Process”, U.S. Pat. No. 4,113,446, 1978.

25. Modell, M., "Processing Methods for the Oxidation of Organics in Supercritical Water", U.S. Pat. No. 4,338,199, 1982.

26. Modell, M., “Treatment of Pulp Mill Sludges by Supercritical Water Oxidation”, Paper No. DOE/CE/40914-T1, 1990. 
27. Patterson, D.A., L. Stenmark and F. Hogan, "Pilot-Scale Supercritical Water Oxidation of Sewage Sludge", presented at the $6^{\text {th }}$ European Biosolids and Organic Residuals Conference, Wakefield, England, November, 2001.

28. Perry, R.H. and D. Green, Perry's Chemical Engineers' Handbook $7^{\text {th }}$ Edition, McGraw-Hill,

29. Rulkens, W.H. et al., "Feasibility Study of Wet Oxidation Processes for Treatment of Six Selected Waste Streams", Dutch Rijkswaterstaat Report No. DBW/RIZA 89-079, 1989.

30. Sealock, L.J. Jr. and D.C. Elliott, "Method for the Catalytic Conversion of Lignocellulosic Materials", U.S. Pat. No. 5,019,135, 1991.

31. TNO poster paper, personal communication from J Zeevalkink, 1998.

32. University of Hawaii at Manoa, "Hydrogen Production by Steam Reforming Glucose in Supercritical Water", D. Yu, M. Aihara and M.J. Antal Jr., Energy and Fuels, 7:574-577, 1993.

33. University of Hawaii at Manoa, "Catalytic Supercritical Gasification of Wet Biomass", M.J. Antal Jr., International patent application WO 96/30464, 1996a.

34. University of Hawaii at Manoa, "Hydrogen Production from High Moisture Content Biomass in Supercritical Water”, M.J. Antal Jr., T. Adschiri, T. Ekbom, A. Garcia, Y. Matsumura, T. Minowa, F. Nuessle, M. Sakurai and X. Xu Proceedings of the U.S. DOE Hydrogen Program Review, Miami, FL, May 1-2, 1996 b.

35. University of Hawaii at Manoa, "Carbon-Catalyzed Gasification of Organic Feedstocks in Supercritical Water”, X. Xu, Y. Matsumura, J. Stenberg and M.J. Antal Jr., Ind. Eng. Chem. Res., 35:2522-2530, 1996c.

36. University of Hawaii at Manoa, "Total, Catalytic, Supercritical Steam Reforming of Biomass", M.J. Antal Jr. and X. Xu, Proceedings of the U.S. DOE Hydrogen Program Review, Herndon, VA, May 21-23, 1997a.

37. University of Hawaii at Manoa, "Gasification of Sewage Sludge and Organics in Supercritical Water", X. Xu and M.J. Antal Jr., AIChE Annual Meeting, Los Angeles, 1997b.

38. University of Hawaii at Manoa, "Hydrogen Production from High Moisture Content Biomass in Supercritical Water", M.J. Antal Jr. and X. Xu, Proceedings of the U.S. DOE Hydrogen Program Review, Alexandria, VA, April 28-30, 1998a.

39. University of Hawaii at Manoa, "Hydrogen Production by the Total, Catalytic, Supercritical Steam Reforming of Wood Sawdust", M.J. Antal Jr. and X. Xu, $216^{\text {th }}$ ACS National Meeting, Boston, August 23, 1998b.

40. University of Hawaii at Manoa, "Hydrogen Production from High Moisture Content Biomass in Supercritical Water", M.J. Antal Jr., S. Allen, J. Lichwa, D. Schulman and X. Xu, Proceedings of the U.S. DOE Hydrogen Program Review, 1999. 
41. Wallman, P.H., J.H. Richardson, C.B. Thorsness, T.F. Leininger, J.D. Klein, J.D. Winter and A.M. Robin, "Hydrogen Production from Municipal Solid Waste", Proceedings of the U.S. DOE Hydrogen Program Review, Miami, FL, May 1-2, 1996.

42. Wang, J and T. Takarada, "Role of Calcium Hydroxide in Supercritical Water Gasification of Low-Rank Coal”, Energy and Fuels, 15:356-362, 2001.

43. Wiltsee, G., “Urban Waste Grease Resource Assessment”, NREL/SR-570-26141, November, 1998.

44. Woerner, G.A., "Thermal Decomposition and Reforming of Glucose and Wood at the Critical Conditions of Water", M.S. Thesis, Massachusetts Institute of Technology, 1976.

45. Whitlock, D.R., "Organic Reactions in Supercritical Water", M.S. Thesis, Massachusetts Institute of Technology, 1978.

46. Wofford, W.T., "The First Commercial SCWO Sludge Processing Plant", presented at Texas Water 2002, Water Environment Association of Texas, Austin.

47. Yeboah, Y.D. et al., "Hydrogen from Biomass for Urban Transportation", Proceedings of the U.S. DOE Hydrogen Program Review, Golden, CO, May 6-8, 2002. 


\section{APPENDIX A}

SWPO BACKGROUND INFORMATION 
Supercritical water partial oxidation (SWPO) is a combination of two precursor technologies, supercritical water gasification (SCWG) and supercritical water oxidation (SCWO). In SCWG, organic material is exposed to a high pressure steam environment and converted to low molecular weight volatile materials, primarily $\mathrm{H}_{2}, \mathrm{CH}_{4}, \mathrm{CO}$ and $\mathrm{CO}_{2}$. In $\mathrm{SCWO}$, excess oxygen is added to the mix to give essentially complete oxidation of organic material to $\mathrm{CO}_{2}$ and $\mathrm{H}_{2} \mathrm{O}$ and liberation of the heat of combustion. In SWPO, an intermediate amount of oxygen is added to provide some heat release while still producing some $\mathrm{H}_{2}, \mathrm{CH}_{4}, \mathrm{CO}$. All of the supercritical water (SCW) processes take advantage of the properties of supercritical water, a unique state of matter with properties intermediate to those of gases and liquids. This appendix provides background material on SCW, SCWG, and SCWO, followed by some comments on their relation to SWPO.

\section{Properties of Supercritical Water (SCW)}

Supercritical water refers to water beyond its thermodynamic critical point of $705^{\circ} \mathrm{F}\left(374^{\circ} \mathrm{C}\right)$ and 3206 psia (22.1 MPa or $218 \mathrm{~atm}$ ). Reactions in SCW are frequently carried out at conditions of $1200^{\circ} \mathrm{F}$ and $3400 \mathrm{psi}$, at which point densities are less than one-tenth that of normal liquid water. At this density water molecules are sufficiently far apart that hydrogen bonding is almost entirely disrupted and the water molecules lose the ordering responsible for many of liquid water's characteristic properties. In particular, the loss of ordering dramatically reduces the bulk polarity of the water as characterized by the dielectric constant.

The loss of bulk polarity by the water phase causes solubility behavior that is closer to that of high-pressure steam than to liquid water. Normally water-soluble salts are no longer readily solvated by water molecules and they precipitate out as solids or dense liquids. Small polar and nonpolar organic compounds, with relatively high volatility, will exist as vapors at typical SCW conditions, and hence will be completely miscible with supercritical water. Gases such as $\mathrm{N}_{2}$, $\mathrm{O}_{2}$, and $\mathrm{CO}_{2}$ show similar complete miscibility. Larger organic compounds and polymers will hydrolyze to smaller molecules at typical SCW conditions, thus resulting in solubilization via chemical reaction. Figure A-1 summarizes the density and typical solubility behavior of compounds in water at 3400 psi as a function of temperature. Figures A-1a and A-1b show the rapid drop in density in the vicinity of the critical temperature, with a concomitant increase in the solubility of nonpolar organics and gases. As shown in Fig. A-1c, high-salt solutions may persist well beyond the critical temperature. This is due to salt stabilization of the dense liquid phase, much as salt raises the boiling temperature of water on a kitchen stove. 


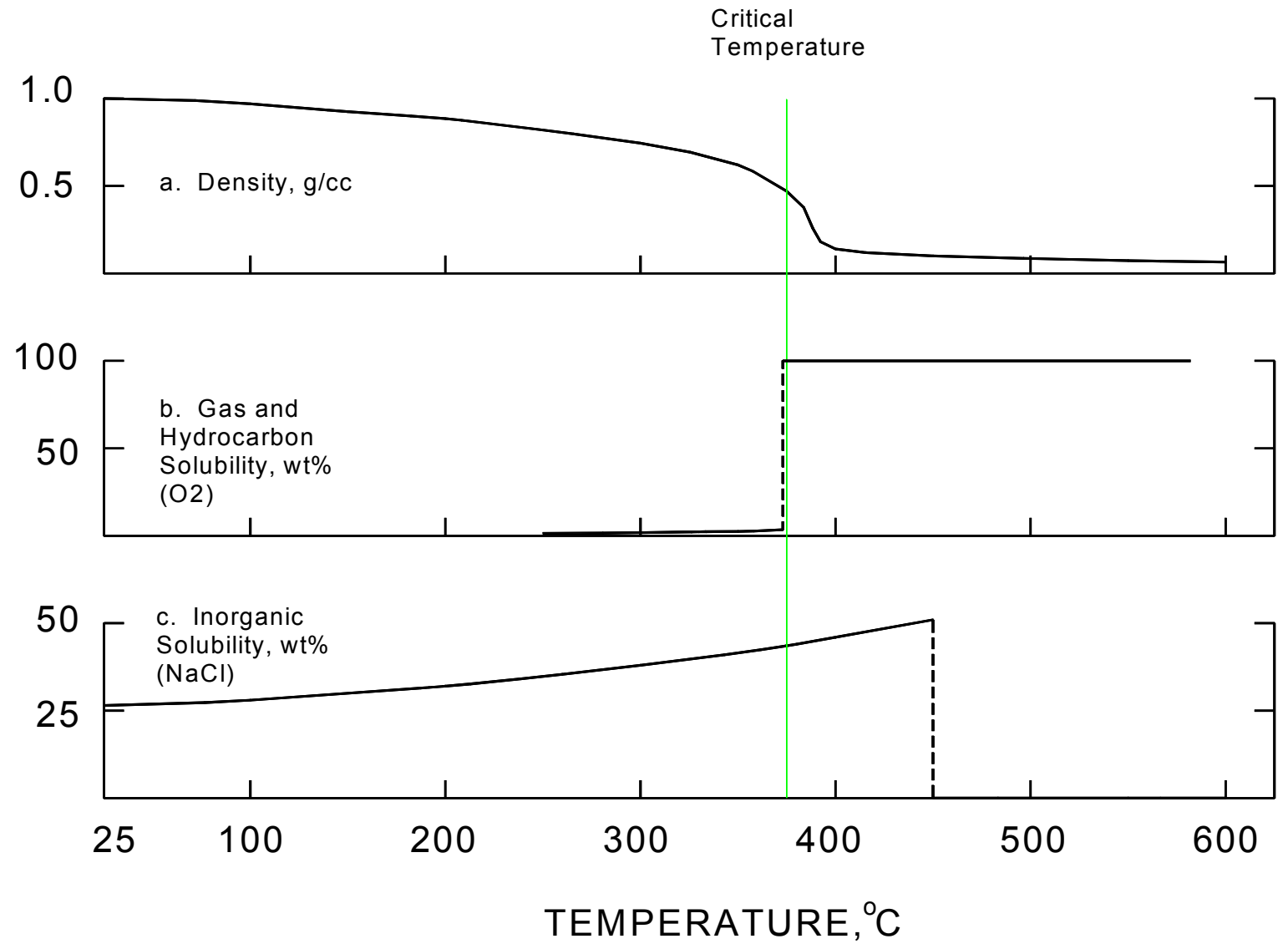

Fig. A-1. Characteristics of water at 3400 psi as a function of temperature. a. Density. b. Solubility of nonpolar organics and permanent gases. c. Solubility of sodium chloride.

\section{Supercritical Water Gasification (SCWG)}

As mentioned above, larger organic compounds and polymers will hydrolyze to smaller molecules at SCW conditions. This phenomenon has given rise to processes to make liquid and/or gaseous products in the SCW medium. For the purposes of hydrogen production we are primarily interested in the gasification reactions.

The earliest tests on gasification in supercritical water were carried out by Modell and coworkers at the Massachusetts Institute of Technology (MIT) in the late 1970's (Modell et al., 1978). These tests utilized residence times of at least 30 minutes with temperature and pressure conditions essentially at water's critical point. Various metallic catalysts were employed. Table A-1 summarizes some of these laboratory-scale results along with representative data from more recent testing. Dramatically improved results have been achieved through the use of higher temperatures and activated carbon catalyst, with reactor residence times as short as 15 seconds. In all cases water is consumed in gas-forming hydrolysis so that the mass of hydrogen in the gas (including primarily $\mathrm{H}_{2}$ and $\mathrm{CH}_{4}$ ) is higher than the mass of hydrogen in the organic feed. 
Table A-1 indicates that activated carbon catalyst is conducive to high gas yields. It is also clear, however, that this catalyst is not universally required. Furthermore, UHM (1996c) reports that the carbon becomes deactivated over the course of several hours.

It has sometimes been reported that char does not form in the SCWG process. More accurately stated, there appear to be some SCW conditions under which char formation is very low or negligible. There are other SCW conditions, however, where char formation has been observed (GA, 1997; UHM, 1999). Higher organic concentrations appear to be more conducive to char formation. It also seems that the formation of high molecular weight hydrocarbons (tar and char) is a function of feed heat-up time (UHM, 1996c), with longer heat-up times yielding higher amounts of these products.

GA's experience with pilot-scale SCWG of sewage sludge is described in Section 4 of this report. 
GA-C24239

TABLE A-1. LABORATORY-SCALE SCWG TEST RESULTS

\begin{tabular}{|c|c|c|c|c|c|c|c|}
\hline Reference & Feedstock & $\begin{array}{l}\mathrm{T}, \\
{ }^{\circ} \mathrm{C}\end{array}$ & $\begin{array}{l}\text { P, } \\
\text { psi }\end{array}$ & Catalyst & $\begin{array}{l}\text { Reaction } \\
\text { Time, min }\end{array}$ & $\begin{array}{c}\% \mathrm{C} \\
\text { Gasified }\end{array}$ & $\begin{array}{c}\text { g H gas } / \\
100 \mathrm{~g} \text { feed }\end{array}$ \\
\hline Modell et al., 1978 & $\begin{array}{l}\text { Glucose } \\
\text { Cellulose }\end{array}$ & 374 & 3200 & Mixed metallic & 30 & $\begin{array}{l}23 \\
18\end{array}$ & $\begin{array}{l}1.4 \\
0.3\end{array}$ \\
\hline Woerner, 1976 & Maple sawdust & 374 & 3200 & None & 30 & 88 & 2.3 \\
\hline Whitlock, 1978 & Glucose & 380 & 4750 & Mixed metallic & 13 & 36 & 0.8 \\
\hline $\begin{array}{l}\text { Sealock and } \\
\text { Elliott, } 1991\end{array}$ & $\begin{array}{c}\text { Cellulose } \\
\text { Holocellulose } \\
\text { Lignin } \\
\text { Wood }\end{array}$ & 400 & 4000 & $\mathrm{Ni} / \mathrm{Cs}_{2} \mathrm{CO}_{3}$ & 15 & $\begin{array}{l}76 \\
70 \\
37 \\
74\end{array}$ & $\begin{array}{l}6.5 \\
5.1 \\
4.1 \\
7.6\end{array}$ \\
\hline UHM, 1993 & Glucose & 600 & 5140 & None & 0.5 & 86 & 11.3 \\
\hline UHM, 1996c & $\begin{array}{l}\text { Glucose } \\
\text { Bagasse } \\
\text { Glycerol }\end{array}$ & 600 & 5140 & $\begin{array}{c}\text { Activated carbon } \\
\text { Activated carbon } \\
\text { None }\end{array}$ & $\begin{array}{c}0.3 \\
1.4 \\
0.75\end{array}$ & $\begin{array}{c}99 \\
100 \\
100\end{array}$ & $\begin{array}{c}8.1 \\
3.3 \\
11.8\end{array}$ \\
\hline UHM, 1996a & $\begin{array}{c}\text { Cellobiose } \\
\text { Water hyacinth }\end{array}$ & 600 & 5140 & Activated carbon & 0.3 & $\begin{array}{l}100 \\
100\end{array}$ & $\begin{array}{l}5.2 \\
9.4\end{array}$ \\
\hline UHM, 1997b & $\begin{array}{c}\text { Corn starch (CS) } \\
\text { Sewage sludge + CS } \\
\text { Sawdust + CS }\end{array}$ & 650 & 4170 & Activated carbon & 0.25 & $\begin{array}{c}100 \\
94 \\
100\end{array}$ & $\begin{array}{l}9.1 \\
8.8 \\
9.6\end{array}$ \\
\hline
\end{tabular}




\section{Supercritical Water Oxidation (SCWO)}

The SCWO process has been under development since the early 1980's. SCWO laboratory studies quickly established that temperatures considerably higher than the critical temperature of water $\left(374^{\circ} \mathrm{C}\right)$, in the range of $600^{\circ} \mathrm{C}$, were desirable to achieve rapid and complete oxidation. In contrast, the pressure functionality was more ambiguous, with good oxidation result being reported at pressures both considerably below and above the critical pressure of 3206 psi (Hong, 1992; Buelow et al, 1990). (For simplicity, the process is still referred to as SCWO, even though the operating pressure may be somewhat subcritical.) The molecular dispersion of the organic and oxidant reactants within a single phase, in conjunction with the high diffusivity, low viscosity, and relatively dense SCW reaction medium, is conducive to rapid oxidation reactions. Furthermore, the temperature is sufficiently high that reaction completion is usually attained within seconds to tens of seconds.

SCWO has proven to be a robust method for the complete oxidation and mineralization of a wide spectrum of materials. Applications of SCWO technology have thus far been primarily targeted at waste destruction applications, where the high destruction efficiencies attainable in compact equipment are very desirable. The process has the capability of operating on a wide range of feed materials, including wet or dirty fuels such as sewage sludge, MSW, or high-sulfur coal. The effectiveness of SCWO has been demonstrated at the laboratory and pilot scale on hundreds of feedstocks. Feedstocks of interest to the current program that have been treated by SCWO include sewage sludge (General Atomics, 1997), black and gray water (GA, 2000), coal slurry (Modar, Inc. unpublished results), pig manure (Rulkens et al., 1989), various biomass slurries including pulp mill sludge (Modell, 1990), pulverized wood with ground plastic, rubber, and charcoal (General Atomics, 1999), fermentation waste (Johnston, et al., 1988) and ground cereal (Hong, et al., 1996). Complete oxidation of virtually any organic material, including highly refractory hazardous wastes such as hexachlorobenzene, has been demonstrated. Regardless of the particular feedstock, the heat of combustion is captured directly within the high-pressure aqueous stream without the need for intervening heat transfer surfaces.

The low temperature of SCWO in comparison to normal combustion has the advantage of reducing $\mathrm{NO}_{\mathrm{x}}$ and $\mathrm{SO}_{\mathrm{x}}$ formation. Typical effluent levels for these gases, even with nitrogencontaining feeds and air oxidant, is less than $1 \mathrm{ppm}$.

\section{Supercritical Water Partial Oxidation (SWPO)}

Like SCWO, SWPO has an inherent advantage over external heating in that the heat of reaction is generated in situ, without the need for any intervening heat transfer surfaces. Thus, the problems of scaling heat transfer surfaces and limited metal strength at high temperatures are largely avoided. Use of pure oxygen or highly enriched air as the process oxidant minimizes the inert gas content of the steam.

As with SCWG and SCWO, rapid reaction times and a relatively dense medium make for compact, heat-efficient equipment in the SWPO process. Compact equipment and heat conservation are the primary factors behind the use of elevated pressures in coal gasification.

Like SCWO, the SWPO process has the capability of operating on a wide range of feed materials, including wet or dirty fuels such as sewage sludge, MSW, or high-sulfur coal. 


\section{APPENDIX B}

SWPO TEST PLAN (APRIL 2001) 
This is the original test plan prepared early in Phase I. During the course of Phase I testing, significant departures were taken from this plan, but the plan was not subsequently updated. However, the plan does provide a basis and context for the work carried out in Phase I. Generally, the departures made from the test plan were due to limitations in the test equipment or unanticipated complications that could not be overcome within the budget and schedule constraints of Phase I. These issues are discussed in the body of the report.

\subsection{OBJECTIVES}

The objectives of the Supercritical Water Partial Oxidation (SWPO) test program will be to demonstrate the potential for economic hydrogen production with minimal or manageable char formation using negative value feedstock. Shakedown tests will be conducted using a model compound that will allow comparison of the test results to results from supercritical water gasification tests. Coal and raw compost will also be tested, as these fuels represent potential fuels for large-scale gasification plants.

The objectives of the test program are to:

- Demonstrate the feasibility of the SWPO process

- Determine the effect of the following process parameters on the Hydrogen yield:

- Solids concentration

- Reactor residence time

- Reactor configuration

- Demonstrate that raw compost can be gasified economically by SWPO

- Determine the operating conditions for a full-scale SWPO demonstration plant

- Develop a material and energy balance and develop a process flow diagram for a full scale SWPO demonstration plant

\subsection{DESCRIPTION OF EQUIPMENT}

The General Atomics SWPO pilot plant has been designed to be a very flexible test apparatus for studying oxidation, partial oxidation and gasification in supercritical water. The pilot plant is equipped with a boiler capable of producing $500 \mathrm{lb} / \mathrm{hr}(3,780 \mathrm{~g} / \mathrm{min})$ of steam or supercritical water. There is also a heat exchanger that can be used to transfer heat from the reactor effluent to the incoming feed stocks. The pilot facility is equipped with two reactors: a downflow reactor which is 2.8 inches $(71.12 \mathrm{~mm})$ inside diameter and 40 inches $(101.6 \mathrm{~cm})$ long; and a tubular reactor which consists of 5 heated sections, 0.861 inches $(21.87 \mathrm{~mm})$ inside diameter and 1,065 inches $(2,682 \mathrm{~cm})$ total in length. All of the reactors have a maximum working pressure of $4,500 \mathrm{psig}(31.1 \mathrm{MPa})$ and a maximum working temperature of $1250{ }^{\circ} \mathrm{F}\left(676{ }^{\circ} \mathrm{C}\right)$. The maximum flow rate through the downflow reactor is about $70 \mathrm{lb} / \mathrm{hr}$ and the maximum flow rate through the tubular reactor is about $175 \mathrm{lb} / \mathrm{hr}$.

Solids are mixed with water up to a feed concentration of $40 \%$ by weight. This mixture is then pumped up to reactor pressure and mixed with hot water, which is at reactor pressure and 1,112 ${ }^{\circ} \mathrm{F}\left(600{ }^{\circ} \mathrm{C}\right)$, in a mixing tee. Mixing the hot water with feed in a 2:1 water to feed ratio, will 
result in a reactor feed that has a solids concentration of approximately $13 \%$ at a temperature over $780^{\circ} \mathrm{F}\left(415^{\circ} \mathrm{C}\right)$, which is well above the temperature where char forms.

Oxygen can either be premixed with the hot water prior to entering the mixing tee, or it can be added downstream of the mixing tee. By premixing the $\mathrm{O}_{2}$ with the water up stream of the mixing tee, the reaction products can be brought up to test temperatures almost instantaneously.

After exiting either the downflow reactor or the tubular reactor, the reactor effluent is cooled to room temperature by water in a heat exchanger. The downflow reactor is also equipped with several quench points, at several different elevations in the reactor, where the effluent can be rapidly cooled by being mixed with an excess of water. These quench points allow the chemical reactions to be stopped quickly in order to study the reaction kinetics. Once cooled, the effluent passes to a flash vessel where gases are separated from the liquid, while the effluent is still under pressure. Control valves, connected to the gas and liquid exit streams, control the pressure in the apparatus. Part of the gas stream is then fed to the continuous gas analyzer system where it is analyzed for $\mathrm{CO}_{2}, \mathrm{CO}, \mathrm{CH}_{4}, \mathrm{O}_{2}$, and $\mathrm{H}_{2}$. Samples of the liquid effluent can also be taken for further analysis.

One drawback to this arrangement is that $\mathrm{CO}_{2}$ dissolves easily in water at the pressures encountered in the flash tank (Divilio 1998). This will help to enrich the gas stream, by removing part of the $\mathrm{CO}_{2}$. However, it will make analyzing the test data more onerous because the $\mathrm{CO}_{2}$ in the liquid effluent will either have to be measured or it will have to be estimated using the Henry constant of $\mathrm{CO}_{2}$ at the conditions in the flash tank. This will be particularly troubling when the reactor quench mechanism is used, because the additional water will dissolve more of the $\mathrm{CO}_{2}$. While this is not an undesirable result in a commercial operation, it will make closing the carbon balance more difficult. To improve the carbon balance, the liquid stream will be sent to a secondary flash vessel after the pressure as been reduced and the flow rate of gases leaving the top of this vessel will be measured and analyzed along with the liquid effluent.

This test program will concentrate primarily on the downflow reactor. If time permits, a test will also be conducted in the tubular reactor to see if the reactor configuration has an impact on the final reaction products. The various quench levels in the downflow reactor will be used to stop the reaction at various times to allow preliminary analysis of the overall reaction kinetics. Because the quench water will cool the reaction products, the feed heat exchanger can not be used to transfer heat from the reactor effluent to the incoming water for these tests. Instead, heated water from the boiler at $1,112^{\circ} \mathrm{F}\left(600^{\circ} \mathrm{C}\right)$ will be mixed with the incoming feed paste to simulate the heat exchange step.

\subsection{FUELS}

Three fuels will be tested in the Supercritical Water Partial Oxidation Pilot Plant. Cornstarch will be the first fuel tested. The University of Hawaii (UHM, 1997a) has tested cornstarch extensively in their supercritical water pyrolysis equipment. As such this fuel will serve as a baseline for comparisons to the supercritical water gasification process. 
In addition to cornstarch, which is a fairly easy material to mix and feed, two solid fuels will also be tested. The first will be coal/water slurry, which contains at least $40 \%$ by weight dry coal. The coal water slurry will either be purchased as pre-mixed slurry or will be manufactured at the pilot plant. The type of coal tested will depend on the availability of coal water slurry. The second solid fuel is a mixture of composted sewage sludge and MSW called Raw Compost. General Atomics has found that they can produce a slurry that contains $40 \%$ by weight dry solids using this material, and it is easily pumped up to supercritical pressure. This material is also readily available and could be a good source of fuel for a larger hydrogen plant.

Because the sludge exists in only limited quantities in any single location, a test will also be conducted using mixtures of coal and raw compost if time permits. The goal of this mixed fuel test will be to test a mixture of $50 \%$ raw compost and $50 \%$ coal at a feed concentration of $40 \%$ by weight of dry solids. If such a mixture can not be easily pumped then a mixture of $75 \%$ sludge and $25 \%$ coal in a feed concentration of at least $40 \%$ by weight of dry solids will be tested.

\subsection{TEST MATRIX}

The current program has only a limited amount of time allocated for testing the pilot plant. A large majority of that time will be spent commissioning the apparatus and ensuring that the data from the test program is of the highest quality. It is estimated that this program will have about 5 days available for data acquisition after the equipment is commissioned. During a test day, it is estimated that 3, or at most 4 test periods can be achieved, assuming about 2 hours to steady state between test conditions. Accordingly, the test matrix has been set-up on the basis of three test periods in a single test day. A fourth test condition will also be specified with the test number designation \#-TP indicating that this test condition will be tested if time permits.

Furthermore, in case the shakedown and commissioning of the pilot plant takes less time than anticipated, two test additional test series will also be described that will be conducted if time permits. These are designated Series 6-TP and Series 7-TP.

Test Series 1 and 2 will be conducted using the model compound cornstarch in the downflow reactor and using the quench system to study the reaction kinetics. The conditions for these two test series will be nearly identical; the only difference being that, in Series 2, the cornstarch paste feed will be heated to $300{ }^{\circ} \mathrm{C}$ prior to entering the mixing nozzle to minimize the use of oxygen and to improve the yield of hydrogen. Test Series 3 will be conducted using coal water slurry as the feed to the downflow reactor. Test Series 4 and 5 will be conducted using the raw compost in the downflow reactor with the raw compost being heated to $300{ }^{\circ} \mathrm{C}$ prior to the mixing tee in Series 5. If time permits, Test Series 6-TP will be conducted using a mixture of $50 \%$ raw compost and $50 \%$ coal in a feed concentration of $40 \%$ by weight of dry solids. Finally, Test Series 7-TP will be conducted using cornstarch and the tubular reactor, at the same test conditions as Series 1, if time permits.

All of the tests will be conducted utilizing the same basic operating procedures. The reactor will be brought up $1,112^{\circ} \mathrm{F}\left(600^{\circ} \mathrm{C}\right)$ and test pressure using the hot water from the boiler flowing at the maximum throughput for the reactor. Once the temperatures have stabilized, the water flow will be reduced to the flow rate for the first test of the series. Next the $\mathrm{O}_{2}$ feed will be set at a minimum flow rate of about $1 \mathrm{lb} / \mathrm{hr}(7.6 \mathrm{~g} / \mathrm{min})$. Finally the fuel paste feed will be initiated at the 
flow rate for the first test. Oxygen feed will then be increased or decreased until the test temperature of $650{ }^{\circ} \mathrm{C}$ is established. All conditions will be kept at steady state throughout the data collection period.

\subsection{Cornstarch Tests}

Three test series are planned using cornstarch as the feed. Series 1 will be conducted using the downflow reactor and various quench levels to study the effect of reaction time on the hydrogen yield. Series 2 will be identical to Series 1 except that the cornstarch paste will be heated to $300{ }^{\circ} \mathrm{C}$ prior to being fed to the mixing tee. The paste will be heated in a section of the tubular reactor, which is electrically heated. The additional heat should result in a decrease in the amount of oxygen needed to bring the reactants up to $650{ }^{\circ} \mathrm{C}$ resulting in improved hydrogen yield. Test Series 6-TP will be conducted using unheated cornstarch feed to the tubular reactor.

\section{$\underline{4.1 .1 \quad \text { Series } 1}$}

Series 1 will consist of 3 (possibly 4 ) tests using the downflow reactor. All tests will be conducted at a reactor pressure of $4075 \mathrm{psig}$ (28 MPa) with oxygen being fed upstream of the mixing tee. The pressure and temperature for these tests were chosen to allow comparison to the cornstarch data from the University of Hawaii. The feedstock for this test will be a $40 \%$ by weight mixture of cornstarch and water. Table B-1 lists the conditions for the Series 1 tests.

TABLE B-1. TEST MATRIX FOR SERIES 1

\begin{tabular}{|c|c|c|c|c|c|c|c|}
\hline \multirow[b]{2}{*}{ Test No. } & \multicolumn{4}{|c|}{ Paste Hot Water Quench } & \multicolumn{3}{|c|}{ Cornstarch Test } \\
\hline & $\begin{array}{l}\text { Feed, } \\
\text { g/min }\end{array}$ & $\begin{array}{l}\text { Feed, } \\
\text { g/min }\end{array}$ & $\begin{array}{l}\text { Water } \\
\text { Level, in. }\end{array}$ & $\begin{array}{c}\text { Paste } \\
\text { Temp, C }\end{array}$ & $\begin{array}{l}\text { Reactor } \\
\text { Temp, }^{\circ} \mathrm{C}\end{array}$ & $\begin{array}{l}\text { Conc. } \\
\text { wt. \% }\end{array}$ & $\begin{array}{c}\text { Duration } \\
\text { Hours }\end{array}$ \\
\hline $1 \mathrm{~A}$ & 105 & 300 & 39 & 25 & 650 & 10.4 & 1.0 \\
\hline 1B & 105 & 300 & 23 & 25 & 650 & 10.4 & 1.0 \\
\hline $1 \mathrm{C}$ & 105 & 300 & 3 & 25 & 650 & 10.4 & 1.0 \\
\hline 1D-TP & 150 & 300 & 39 & 25 & 650 & 13.3 & 1.0 \\
\hline
\end{tabular}

Quench water level in Table 1 is indicated as measured from the entrance of the reactor. In this series, changes to the oxygen feed rate will be used to control reactor temperature. The tests will study the effect of residence time in the reactor. Oxygen requirements for these tests range from 2 to $2.8 \mathrm{lb} / \mathrm{hr}$ (15 to $21.2 \mathrm{~g} / \mathrm{min}$ ). Tests $1 \mathrm{~A}, 1 \mathrm{~B}$, and $1 \mathrm{C}$ represent the feed conditions for the University of Hawaii's tests on cornstarch.

\section{$\underline{4.1 .2}$ Series 2}

Series 2 will test preheating the cornstarch feed paste up to $300{ }^{\circ} \mathrm{C}$ prior to feeding to the mixing tee. By heating the paste feed, the oxygen requirements should be decreased by about $30 \%$, which should increase the hydrogen yield. All tests will be conducted at a reactor pressure of 4075 psig ( $28 \mathrm{MPa}$ ) with oxygen being fed upstream of the mixing tee. The feedstock for this test will be a $40 \%$ by weight mixture of cornstarch and water. Table B-2 lists the conditions for the Series 2 tests. 
GA-C24239

TABLE B-2. TEST MATRIX FOR SERIES 2

\begin{tabular}{|c|c|c|c|c|c|c|c|}
\hline \multirow[b]{2}{*}{ Test No. } & \multicolumn{3}{|c|}{ Paste Hot Water Quench } & \multirow[b]{2}{*}{$\begin{array}{c}\text { Paste } \\
\text { Temp, C }\end{array}$} & \multicolumn{3}{|c|}{ Cornstarch } \\
\hline & $\begin{array}{l}\text { Feed, } \\
\text { g/min }\end{array}$ & $\begin{array}{l}\text { Feed, } \\
\text { g/min }\end{array}$ & $\begin{array}{c}\text { Water } \\
\text { Level, in. }\end{array}$ & & $\begin{array}{l}\text { Reactor } \\
\text { Temp, }{ }^{\circ} \mathrm{C}\end{array}$ & $\begin{array}{l}\text { Conc. } \\
\text { wt. } \%\end{array}$ & $\begin{array}{c}\text { Duration } \\
\text { Hours }\end{array}$ \\
\hline $2 \mathrm{~A}$ & 105 & 300 & 39 & 300 & 650 & 10.4 & 1.0 \\
\hline $2 \mathrm{~B}$ & 105 & 300 & 23 & 300 & 650 & 10.4 & 1.0 \\
\hline $2 \mathrm{C}$ & 105 & 300 & 3 & 300 & 650 & 10.4 & 1.0 \\
\hline 2D-TP & 150 & 300 & 39 & 300 & 650 & 13.3 & 1.0 \\
\hline
\end{tabular}

The test conditions for this series of tests are the same as the ones used for Series 1. At the end of this test series, the mixing nozzle and the paste feed heater will be carefully examined for evidence of carbon formation. In addition, the reactor effluent will also be examined carefully for char.

\subsubsection{Series 7-TP}

This test series will be run after Series 1 through 5 and 6-TP are completed, if time permits. The purpose of this test series is to observe the effect that the reactor configuration has on the hydrogen yields. For this series, the tubular reactor will be utilized. The reaction time in the tubular reactor is set by the flow rate of fluid through the reactor. The time in the downflow reactor for Tests $1 \mathrm{~A}$ and $2 \mathrm{~A}$ is estimated to be about 42 seconds. In order to achieve this reaction time in the tubular reactor the flow rate of material will have to be about 2.56 times greater than the flows in the downflow reactor. Test 7A-TP will match the residence time in the downflow reactor of 42 seconds. The remaining tests will look at the effect of longer residence times by decreasing the flow rate through the reactor.

The oxygen feed will be located upstream of the mixing tee as in Series 1 . The concentration of cornstarch in the feedstock will be $40 \%$ by weight, and the reactor pressure will be 4075 psig (28 MPa). Table B-3 lists the test conditions for Series 7-TP.

TABLE B-3. TEST MATRIX FOR SERIES 7-TP

\begin{tabular}{|c|c|c|c|c|c|c|}
\hline Test No. & $\begin{array}{l}\text { Paste } \\
\text { Feed, } \\
\text { g/min }\end{array}$ & $\begin{array}{l}\text { Hot Water } \\
\text { Feed, } \\
\text { g/min }\end{array}$ & $\begin{array}{c}\text { Paste } \\
\text { Temp, }{ }^{\circ} \mathrm{C}\end{array}$ & $\begin{array}{l}\text { Reactor } \\
\text { Temp, }{ }^{\circ} \mathrm{C}\end{array}$ & $\begin{array}{c}\text { Cornstarch } \\
\text { Concentration } \\
\text { wt. } \%\end{array}$ & $\begin{array}{c}\text { Test } \\
\text { Duration } \\
\text { Hours }\end{array}$ \\
\hline 7A-TP & 270 & 770 & 25 & 650 & 10.4 & 1.0 \\
\hline 7B-TP & 270 & 385 & 25 & 650 & 16.5 & 1.0 \\
\hline 7C-TP & 135 & 385 & 25 & 650 & 10.4 & 1.0 \\
\hline 7D-TP & 105 & 300 & 25 & 650 & 10.4 & 1.0 \\
\hline
\end{tabular}

Test conditions for test 7A-TP are approximately the same as for Test $1 \mathrm{~A}$. The other tests look at the effect of feed concentration and residence time.

\subsection{Solid Fuel Tests}


Test Series 1 and 2 will provide valuable information regarding the performance of heavily oxygenated compounds under SWPO conditions. However, there is another class of organic compounds that contain considerably less oxygen than cornstarch. These compounds include coal and raw compost. Because these compounds contain less oxygen than the cornstarch, they will have a higher requirement for, oxygen per pound of dry fuel, to bring the reactants up to the test temperature.

\subsubsection{Series 3 Coal}

Because of the availability of coal, this fuel would be an ideal gasification fuel for very largescale plants. In this test series, a coal/water slurry containing $40 \%$ by weight coal in water will be used for the feed paste. Oxygen feed will be upstream of the mixing tee. The downflow reactor will be used for these tests at a pressure of 4075 psig (28 MPa).

In this series, two, or possibly three if time permits, concentrations of coal in the stream leaving the mixing tee will be tested, ranging from $8 \%$ to as high as $13.3 \%$ by weight. Feed rates of paste and water were chosen so that the oxygen demand to achieve the test temperature does not exceed the feed limits of $5 \mathrm{lb} / \mathrm{hr}$. The feed stream of the coal water slurry will not be heated in these tests. Furthermore, in all of these tests, the quench level in the down flow reactor will be 39 inches to provide the longest possible residence time for the solid fuel to be consumed. Table B-4 lists the test conditions for Series 3.

TABLE B-4. TEST MATRIX FOR SERIES 3

\begin{tabular}{|c|c|c|c|c|c|c|}
\hline Test No. & $\begin{array}{l}\text { Paste } \\
\text { Feed, } \\
\text { g/min }\end{array}$ & $\begin{array}{l}\text { Hot Water } \\
\text { Feed, } \\
\text { g/min }\end{array}$ & $\begin{array}{c}\text { Paste } \\
\text { Temp, }{ }^{\circ} \mathrm{C}\end{array}$ & $\begin{array}{c}\text { Reactor } \\
\text { Temp, }^{\circ} \mathrm{C}\end{array}$ & $\begin{array}{c}\text { Coal } \\
\text { Concentration } \mathrm{D} \\
\text { wt. } \% \\
\end{array}$ & $\begin{array}{l}\text { Test } \\
\text { Duration } \\
\text { Hours }\end{array}$ \\
\hline $3 A$ & 75 & 300 & 25 & 650 & 8.0 & 1.0 \\
\hline $3 B$ & 100 & 300 & 25 & 650 & 10.0 & 1.0 \\
\hline $3 C$ & 170 & 510 & 25 & 650 & 10.0 & 1.0 \\
\hline 3D-TP & 170 & 350 & 25 & 650 & 13.1 & 1.0 \\
\hline
\end{tabular}

In all of these tests, the mixture of coal and water leaving the mixing tee will contain coal in excess of the amount that could be burned by the oxygen being fed. Therefore, there will be some solid char that will be free to react with the supercritical water. If this reaction occurs forming $\mathrm{CO}$, which will further react with water to form hydrogen and $\mathrm{CO}_{2}$, then there exists the potential for hydrogen yields in excess of $100 \%$ of the hydrogen being fed to the reactor in the coal. The reactor effluent from these tests will be studied carefully to determine the fate of this free char. Oxygen demand for these tests is expected to range from 2.1 to $4.4 \mathrm{lb} / \mathrm{hr}$ (15.9 to $33.3 \mathrm{~g} / \mathrm{min}$ ) 


\subsubsection{Series 4 Raw Compost}

General Atomics has found that they can produce raw compost slurry, which contains over $40 \%$ by weight solids, and can still be fed through a pump. Because this material represents a promising feedstock for a larger hydrogen plant, it has been chosen for testing in this program. In this series raw compost will be tested in the downflow reactor at a pressure of 4075 psig (28 $\mathrm{MPa})$.

The raw compost is very high in ash (about $25 \%$ of the dry solids is ash). Therefore, in spite of the fact that the concentration of raw compost after the mixing tee will be as high as $13.3 \%$ by weight, the concentration of organics will be somewhat lower than that. Also, because the sludge is higher in oxygen than coal, the oxygen demand for this fuel will be slightly lower than the oxygen demand for the coal tests. Table B-5 lists the test conditions for Series 4 .

TABLE B-5. TEST MATRIX FOR SERIES 4

\begin{tabular}{|c|c|c|c|c|c|c|}
\hline Test No. & $\begin{array}{l}\text { Paste } \\
\text { Feed, } \\
\text { g/min }\end{array}$ & $\begin{array}{l}\text { Hot Water } \\
\text { Feed, } \\
\text { g/min }\end{array}$ & $\begin{array}{c}\text { Paste } \\
\text { Temp, }{ }^{\circ} \mathrm{C}\end{array}$ & $\begin{array}{l}\text { Reactor } \\
\text { Temp, }{ }^{\circ} \mathrm{C}\end{array}$ & $\begin{array}{c}\text { Solid } \\
\text { Concentration } \\
\text { wt. } \%\end{array}$ & $\begin{array}{c}\text { Test } \\
\text { Duration } \\
\text { Hours }\end{array}$ \\
\hline $4 \mathrm{~A}$ & 75 & 300 & 25 & 650 & 8.0 & 1.0 \\
\hline 4B & 100 & 300 & 25 & 650 & 10.0 & 1.0 \\
\hline $4 \mathrm{C}$ & 170 & 510 & 25 & 650 & 10.0 & 1.0 \\
\hline 4D-TP & 170 & 350 & 25 & 650 & 13.1 & 1.0 \\
\hline
\end{tabular}

\subsubsection{Series 5 Raw Compost}

In this test series, raw compost will again be tested. This time the feed paste will be heated to $300{ }^{\circ} \mathrm{C}$ using hot water from the boiler. All other conditions for this test series will be the same as for series 4 . Table B-6 lists the test conditions for Series 5.

TABLE B-6. TEST MATRIX FOR SERIES 5

\begin{tabular}{|c|c|c|c|c|c|c|}
\hline Test No. & $\begin{array}{l}\text { Paste } \\
\text { Feed, } \\
\text { g/min }\end{array}$ & $\begin{array}{l}\text { Hot Water } \\
\text { Feed, } \\
\text { g/min } \\
\end{array}$ & $\begin{array}{c}\text { Paste } \\
\text { Temp, }{ }^{\circ} \mathrm{C}\end{array}$ & $\begin{array}{c}\text { Reactor } \\
\text { Temp, }^{\circ} \mathrm{C} \\
\end{array}$ & $\begin{array}{c}\text { Solids } \\
\text { Concentration } \\
\text { wt. } \% \\
\end{array}$ & $\begin{array}{c}\text { Test } \\
\text { Duration } \\
\text { Hours }\end{array}$ \\
\hline $5 A$ & 75 & 300 & 300 & 650 & 8.0 & 1.0 \\
\hline $5 B$ & 100 & 300 & 300 & 650 & 10.0 & 1.0 \\
\hline $5 \mathrm{C}$ & 170 & 510 & 300 & 650 & 10.0 & 1.0 \\
\hline 5D-TP & 170 & 350 & 300 & 650 & 13.1 & 1.0 \\
\hline
\end{tabular}




\subsubsection{Series 6-TP Sludge and Coal}

This test series will be conducted if time permits. In Series 6 a mixture of the raw compost will be mixed with coal. The goal of this series will be to utilize a mixture that is $50 \%$ raw compost and $50 \%$ coal by weight in slurry that is $40 \%$ by weight dry solids. However, if $40 \%$ slurry proves to be impossible to pump, slurry consisting of $75 \%$ raw compost and MSW plus $25 \%$ coal will be tested.

In this series the tests will be conducted in the downflow reactor with the 39 inch quench level. Table B-7 shows the test conditions for Series 6 assuming the 50-50 mixture can be pumped up to test pressure. If the $75-25$ mixture is used, the flow rates will be the same, assuming the concentration of the sludge is $40 \%$ by weight dry solids.

TABLE B-7. TEST MATRIX FOR SERIES 6-TP

\begin{tabular}{|c|c|c|c|c|c|c|}
\hline Test No. & $\begin{array}{l}\text { Paste } \\
\text { Feed, } \\
\text { g/min }\end{array}$ & $\begin{array}{l}\text { Hot Water } \\
\text { Feed, } \\
\text { g/min }\end{array}$ & $\begin{array}{c}\text { Paste } \\
\text { Temp, }{ }^{\circ} \mathrm{C}\end{array}$ & $\begin{array}{l}\text { Reactor } \\
\text { Temp, }{ }^{\circ} \mathrm{C}\end{array}$ & $\begin{array}{c}\text { Solids } \\
\text { Concentration } \\
\text { wt. } \%\end{array}$ & $\begin{array}{l}\text { Test } \\
\text { Duration } \\
\text { Hours }\end{array}$ \\
\hline $6 \mathrm{~A}-\mathrm{TP}$ & 75 & 300 & TBD & 650 & 8.0 & 1.0 \\
\hline 6B-TP & 100 & 300 & TBD & 650 & 10.0 & 1.0 \\
\hline 6C-TP & 170 & 510 & TBD & 650 & 10.0 & 1.0 \\
\hline 6D-TP & 170 & 350 & TBD & 650 & 13.1 & 1.0 \\
\hline
\end{tabular}

The paste feed temperature will be determined based on the results of Series 4 and 5 . This test series will only be conducted if Series 1 through 5 are completed with sufficient test time remaining in the program.

\subsection{Test Matrix Summary}

Overall a total of 15 separate tests will be conducted during this test program, with an additional 13 tests if time permits. Of these, between 6 and 12 tests will be conducted using cornstarch, 3 or 4 will test coal/water slurry, and 6 or 8 will test raw compost. An additional 3 or 4 will test a mixture of the raw compost and coal if time permits. All of the solid fuel tests were designed to provide data at three solid concentrations and three reactor flow rates.

It should be pointed out that, because of the exploratory nature of this test program, it is possible that the test conditions listed in this plan could change, depending on results of earlier tests. If this proves to be the case, a revised test plan will be issued prior to the resumption of testing. Furthermore, if time permits, a more detailed parametric test program could be started to examine other test conditions, such as reactor pressure, reactor temperature, and feed concentrations. 


\subsection{DATA REDUCTION}

Carbon, hydrogen and total mass balances will be performed for all of the test periods. During the solid fuel tests, ash balances will also be performed. Furthermore, during one of the Series 3 tests, the coal/water slurry series, samples of all incoming and exiting streams will be analyzed for sulfur in order to perform a sulfur balance. A sulfur balance will be critical to any process that gasifies coal in order to determine the fate of the fuel bound sulfur.

Hydrogen yield will also be calculated as a percentage of the mass of hydrogen gas that is produced divided by the weight of hydrogen in the dry fuel entering the process. Note it is anticipated that the hydrogen yield from the SWPO process will be lower than the hydrogen yield from a supercritical gasification process operating under the same conditions. This is because some of the fuel is burned in the reactor, rather than externally to the reactor, as would be the case for a gasification process.

A total gaseous hydrogen yield will also be calculated. This yield includes the hydrogen in the methane gas produced as well as the free hydrogen. This value will be an important number because it will indicate whether any water is being consumed by the gasification reactions. A total gaseous hydrogen yield greater than $100 \%$ will show that water is being split by the reactions.

Energy balances will not be possible for these tests. This is because the reactors are heated with electric resistance heaters to supplement their insulation and the energy input to the heaters is not measured. However, the ratio of the chemical energy in the gas stream divided by the chemical energy in the feed will be calculated. This ratio will provide some measure of the thermal conversion of this process.

\subsection{CHEMICAL ANALYSES}

The SWPO pilot plant is equipped with on-line gas analyzers to measure the composition of the gaseous products from the reactor. These analyzers include $\mathrm{CO}_{2}, \mathrm{CO}, \mathrm{CH}_{4}, \mathrm{O}_{2}$, and $\mathrm{H}_{2}$. These analyzes will provide a continuous record of the composition of the gas stream during the tests.

The mass balances will require analyzing the feed stock and the liquid effluent from the reactor in addition to the gas measurements. The feed paste should be analyzed for the following compounds:

Water
Carbon
Hydrogen
Nitrogen
Sulfur
Ash
Oxygen (by difference)
Higher Heating Value (HHV), Btu/lb

These analyses are typical analyses performed during an Ultimate analysis of coal. 
Since one batch of fuel paste will be mixed for each test series, only one analysis is needed for the solid fuel in the paste. The paste will be stored in a continuously stirred tank to ensure uniformity of the feed concentration. A 100-gram sample of the feed paste should be taken during each test as close to the feeder as possible and marked with the time the sample was taken. These samples should be weighed and then dried separately in an oven at a temperature of $110{ }^{\circ} \mathrm{C}$ until there is no further weight loss. The initial and final weights should be recorded and used to calculate the water content of the feed paste for each test. After the samples have been dried, they should be blended to form one composite sample of the solids that is representative for the entire test series. This sample can then be sent out to an independent laboratory for an ultimate analysis.

Since cornstarch is quite uniform in composition, it only needs to be analyzed once before it is mixed with the water to form the feed paste. If the cornstarch used for all of the test series is from the same shipment, it will not need to be analyzed separately for each test series. However, if a different shipment is used, then one sample from each shipment of cornstarch will be required. Moisture determinations, described above, should be performed for every cornstarch test period.

The liquid effluent stream should be analyzed for $\mathrm{CO}_{2}$ and total organic carbon (TOC). During the solid fuel tests, the liquid effluent stream should also be analyzed for ash and carbon in the ash. Carbon in the ash will be an important indicator of the amount of char remaining after the gasification process. While thermodynamics predicts that all of the char will react with water, the rate of this reaction will have a bearing on the final char concentration in the ash stream. The two reactor flow rates used for the solids fuel tests at the $10 \%$ feed concentration will provide insight into this reaction rate.

During Test 3C, a sulfur balance will also be performed. This will require an analysis for sulfur in the gaseous stream and in the liquid effluent. Grab samples of these two streams will be taken during this test for analysis. The gaseous stream should be analyzed for $\mathrm{H}_{2} \mathrm{~S}$. The liquid effluent should be analyzed for $\mathrm{H}_{2} \mathrm{~S}$ and $\mathrm{H}_{2} \mathrm{SO}_{4}$ and the ash in the liquid effluent should be analyzed for sulfur.

\subsection{DATA ACQUISITION}

The SWPO pilot plant is equipped with a data acquisition system which continuously records temperatures and pressures throughout the apparatus. The data acquisition system also continuously records the gas analyses from the gas analyzer system. The flow rates of hot water, paste feed, oxygen, cooling water, gas produced from the high pressure flash tank, gas produced from the low pressure flash tank, and liquid effluent will also be recorded either by the data acquisition system or by hand during the tests. The gas and liquid effluent flow rates will be measured upstream of any point where samples are removed for analysis. Any measurement that is hand recorded will be taken at least three times during the tests period, once at the beginning, once in the middle and once just before the end of the data acquisition period. All data taken during a test period will be averaged over the duration of the test to give an average measurement for the test. 
The downflow reactor and the tubular reactor are equipped with several thermocouples located at various locations in the reactor. The average of al these thermocouples will be considered the test temperature when reporting the test results. Temperature profiles will be plotted to determine if any temperature variations exist throughout the reactor.

\subsection{REFERENCES}

1. Divilio, R. J., "Gas Clean-up Model for the University of Hawaii's Supercritical Water Reactor, Activity 3 Report " NREL Report, Subcontract Number AXE-8-17103-01, July 241998.

2. Antal, J. A. Jr. and X. Xu, "Hydrogen Production from High Moisture Content Biomass in Supercritical Water", Proceedings of the 1998 US DOE Hydrogen Program Review Meeting, Alexandria, VA, April 28-30, 1998. 


\section{APPENDIX C}

\section{BUSINESS PLAN}




\section{Vision/Mission}

\section{Present Situation}

The beneficial use of biomass for the production of hydrogen promises to be a key element in developing a hydrogen-based economy that can lead to energy independence for the U.S. and long-term reduction in the growth of atmospheric greenhouse gases. Due to its ability to process negative and low value feedstocks, supercritical water partial oxidation (SWPO) has been found to be competitive with other means of producing hydrogen from biomass, and in the competitive range with steam reformed methane gas. SWPO of biomass has the potential to produce hydrogen from feeds with high moisture or hazardous waste content not suitable for gasification by other means, e.g., sewage sludge solids, waste grease, and municipal solid waste. SWPO is a compact high-pressure process that produces hydrogen at elevated pressure, ideal for storage. SWPO is also an environmentally clean process producing clean water and gaseous effluents, plus ash for disposal. The SWPO processing of low-value feeds, particularly sewage sludge solids coprocessed with grease trap waste, can result in hydrogen production costs that are significantly lower than those associated with biomass feeds derived from a dedicated feedstock supply such as energy crops. Thus sewage sludge solids can be viewed as one of the primary biomass feeds for cost-effective hydrogen production and power generation using SWPO. While alternative sludge solids disposal methods exist or are being developed, virtually all involve cost penalties to wastewater treatment facility operators. The identification of low or negative value feedstocks with high heating value such as grease trap waste to coprocess with the sludge solids is another key to the economic production of hydrogen using SWPO.

There exist several factors that may limit the near-term applicability of SWPO for hydrogen production. At the present time, a hydrogen-based economy does not exist and it is likely to be several decades before one develops that could make use of SWPO-produced hydrogen on a large, widely-dispersed scale. While near-term "across-the-fence" sales of hydrogen are possible, these are likely to occur only in areas that make significant use of hydrogen, e.g., those near oil refineries or other end users. Thus near-term economic justification for SWPO system sales would be driven mainly by avoided sludge solids disposal costs or similar local circumstances instead of revenue from hydrogen generation. This might lead to the initial use of SCWO, the oxidation precursor technology to SWPO, for disposal of sludge solids at reduced disposal costs. Market entry with SCWO would minimize impact on the facility. SCWO is a mature technology that is beginning to enter the sewage sludge market in the U.S. and abroad. Eventually, as SWPO matures, the SCWO plants could be retrofitted to SWPO plants for hydrogen production at about the same time a market is emerging for distributed hydrogen consumption for fixed and mobile fuel cell applications.

A second factor is the relative immaturity of the SWPO technology vis-à-vis that which is normally accepted as viable and market-ready for large-scale, commercial installations. While both laboratory- and pilot-scale SWPO tests have shown favorable generation of hydrogen from biomass, they are limited in duration. However, they form a strong basis for additional testing to demonstrate long-term performance of the SWPO process. Phase II of the ongoing program with the DOE will include extended duration testing of sludge solids and waste grease in order 
to demonstrate technology maturity and support the development in Phases III and IV of a reduced-scale ( $5 \mathrm{tpd}$ ) demonstration plant at a municipal wastewater facility such as Encina.

The following sections of the business plan present the framework for development of SWPO as a commercial business based on the following provisos:

1. A hydrogen economy continues to develop that is increasingly focused on hydrogen production from biomass feeds versus feedstocks that contribute to increased $\mathrm{CO}_{2}$ loading in the atmosphere (e.g., fossil fuel reforming).

2. Continuing development and scale-up of the SWPO process in Phases II through IV and verification of performance and cost projections.

Many of the features included in a typical near-term business plan, e.g., definition of business type, management team members, details of manufacturing and supply, have not been described in detail since they are dependent on the outcome of pre-commercial activities planned for the next several years. However, it is envisioned that the business will develop as a natural extension of GA's on-going supercritical water oxidation (SCWO) program that is several years ahead of SWPO development and commercialization. For the sake of clarity, the name "SWPO Systems" will represent the business entity in the remainder of the business plan.

\section{Vision and Mission}

Our vision is that SWPO Systems will become a dominant source for environmentally friendly, sustainable production of hydrogen in the 21 st century. To realize this vision, our mission is to become the provider of reliable, cost-effective SWPO systems and services for the production of hydrogen and power from biomass. Our near-term focus for the business will be to provide systems and services to the wastewater treatment industry for the disposal of sludge solids together with waste grease and concomitant production of hydrogen. As we develop the technology and market for SWPO, we will expand our target market to other large, reliable sources of low or negative-value biomass such as sorted MSW, animal wastes, forest product wastes, as well as low grade fossil fuels such as high-sulfur coal or petroleum coke.

\section{Goals and Objectives}

The primary goals and objectives for development of SWPO as a successful business for hydrogen production are described below. Fig. C-1 presents a summary timetable of precommercial (Phase II), near-commercial (Phases III and IV) and commercial activities.

1. Complete pilot-scale development and demonstrate reliable, cost-effective operation of SWPO reduced-scale system. Under Phases II through IV of the GA/DOE program preceding commercial activities, additional pilot-scale testing will be performed during Phase II with sludge solids, grease and other targeted feedstocks, followed by the development of a one-eighth commercial scale (5 tpd) system during Phases III and IV to demonstrate the SWPO process at reducedscale. The results of this 6-year development program will validate the process 
performance, reliability, and economic projections for the SWPO process. The 5 tpd reduced-scale system will be moved to a wastewater treatment facility for on-site testing to demonstrate long-term operation, and to develop industry interest and confidence in SWPO for sludge solids treatment and hydrogen production. Design of a commercial-size SWPO system will likely begin during the latter part of this work, incorporating lessons learned from on-site testing and operations.

Simultaneously, active marketing of SWPO systems will begin with the wastewater industry, with the intent of acquiring the initial customer for the system.

2. Sell the initial SWPO commercial-scale system. Based on successful completion of testing of the reduced-scale SWPO system at a wastewater treatment facility, the first commercial SWPO system will be sold to a large wastewater treatment facility, possibly with a lease-back provision to an independent operating company. The initial commercial plant size, $40 \mathrm{tpd}$, is compatible with the processing rate of a large number of wastewater treatment facilities and represents a credible eight-fold increase in throughput over the reduced-scale system. Following successful operation of this unit, additional sales of this size unit are anticipated.

\section{Product Strategy}

With the successful completion of Phase I, the remaining pre-commercial research and development is embodied in Phase II of the GA/DOE SWPO technical plan. The remaining tasks are defined that build on work to date in Phase I of the GA/DOE program. Scoping tests will be performed in the GA pilot plant to resolve remaining technical issues. Then the pilot plant will be upgraded with advanced SWPO system components and tested with target feedstocks for extended durations.

Phase III, System Integration and Design, is focused on design and long-lead procurement for a new reduced-scale system. Phase IV, reduced-scale demonstration of a 5 tpd system, will complete the fabrication and systemization of the near-commercial system and then verify performance, reliability, and process economics at a wastewater treatment facility. 


\begin{tabular}{|c|c|c|c|c|c|c|c|c|c|c|}
\hline קו & TTak Name & 2003 & 2004 & 2005 & \begin{tabular}{|l|l}
2006 \\
\end{tabular} & 2007 & 2008 & 2009 & \begin{tabular}{|l|}
2010 \\
\end{tabular} & \begin{tabular}{|l|}
2011 \\
\end{tabular} \\
\hline 1 & $\begin{array}{l}\text { Technology Development (GADDOE } \\
\text { Phase II) }\end{array}$ & & & & & & & & & \\
\hline 2 & $\begin{array}{l}\text { System Integration and Design (GAVDOE } \\
\text { Phase III) }\end{array}$ & & & & & & & & & \\
\hline 3 & $\begin{array}{l}\text { Reduced-Scale Demonstration of 5-tpd } \\
\text { System (GA/DOE Phase IV) }\end{array}$ & & & & & & & & & \\
\hline 4 & $\begin{array}{l}\text { Design and Construction of } 40 \text { tpd } \\
\text { Commercial System }\end{array}$ & & & & & & & & & \\
\hline
\end{tabular}

Figure C-1. Schedule for SWPO development and commercialization 


\section{PHASE II - TECHNOLOGY DEVELOPMENT}

\section{Work Scope}

During Phase II, further development of SWPO technology will be performed to resolve remaining technical issues, and to establish performance requirements and system interfaces for Phase III, System Integration and Design. The technical issues requiring further development were previously discussed in Section 4. Following the scoping tests to resolve these technical issues, the GA pilot plant will be upgraded with advanced SWPO system components. Then, extended duration testing will be carried out with the key target feed, sewage sludge plus grease trap waste, to demonstrate long-term operability of the SWPO process.

\section{Task 1 - Develop Advanced SWPO Gasification System}

SWPO Scoping Tests. A number of potential process performance improvements were identified during Phase I testing that will require scoping tests early in Phase II to provide data for the design of an advanced SWPO gasification system. Each test will generally last from 4-8 hours, sufficient to acquire good quality steady state test data. The existing GA Pilot Plant will be used to perform the following series of tests:

Reduce Residual Char Formation and Increase Gasification. Reduce residual char formation and increase gasification by improving feed nozzle mixing and increasing solids residence time at temperature. Verify that the rate of char/ash buildup and removal in the reactor and heatrecovery heat exchanger are manageable. Improve pilot plant instrumentation/diagnostics to improve mass balance and yield calculations. Install an improved product gas flow instrument. Improve char collection and quantification by using straight line heat exchangers with access at both ends for routine cleaning.

Verify Gasification Yields with Target Feeds. Verify Phase I gasification yields with more representative feeds of 1) sewage sludge + trap grease, 2) micronized wood + trap grease, and 3 ) sewage sludge or micronized wood + micronized plastic or tire rubber. Phase I gasification yields for wood flour-ethanol feeds were generally in the range of $80-90 \%$, with about $10-20 \%$ char and tar formation due to inadequate mixing and solids residence time. Improvements described earlier are expected to improve yields for a wide range of feeds, including sewage sludge coprocessed with grease trap waste, and other targeted feeds.

Paragraphs deleted due to proprietary content. 
Design, Fabrication and Installation of Advanced SWPO Gasification System. As the above data for potential process improvements becomes available, decisions can be made about the preferred design for an advanced SWPO gasification system. Based on the Phase I results, it is anticipated that the advanced system will have the following characteristics:

- Downflow (or reversing flow) catalyst-free SWPO gasification reactor with internal liner enabling operation up to $800^{\circ} \mathrm{C}$.

- A heat-recovery heat exchanger for preheating pumpable feeds up to $250^{\circ} \mathrm{C}$.

- A pressurized catalytic reformer for conversion of methane produced in the SWPO reactor.

Paragraphs deleted due to proprietary content.

Based on the scoping tests, some or all of the above characteristics will be selected for the advanced SWPO gasification system. New components, such as the pressurized reformer, will be fabricated and installed in the pilot plant using existing hardware. Additional design modifications identified during the scoping tests will also be implemented to facilitate efficient integrated operation of the advanced SWPO gasification system during extended demonstration testing in Task 2.

\section{Task 2 - Systematize and Test Advanced SWPO Gasification System}

Once the installation of the advanced SWPO gasification system additions and modifications is complete, systemization of the integrated system will begin under Task 2. Systemization will consist of a step-wise startup and automation of the integrated system with representative feeds. Modifications to instrumentation and controls will be made as appropriate to assure robust, long-term operability.

Once systemization is complete, one or more long-term operability tests will be performed with representative feeds similar to those used in Task 1 . Reliability and maintenance data will be recorded, along with the gasification data and system operating parameters. Test duration will be $50-100 \mathrm{hrs}$, with liquid and gas effluent samples taken at routine intervals throughout the tests. 


\section{Task 3 - Perform Special Studies and Update SWPO Development Plan}

In parallel with the Task 1 and 2 work, several studies will be performed to accumulate relevant technical and economic data for target SWPO feedstocks and other biomass-to-energy systems for comparison to the SWPO system.

Feedstock Supply Assessment for Advanced SWPO Gasification Systems. A feedstock supply assessment will be performed to estimate the quantities of selected biomass fuels that are available for the advanced SWPO gasification system, including sewage sludge (SS), sorted municipal solid waste (SMSW), grease trap wastes, animal wastes, and potentially other (not yet identified) opportunity feeds. The focus will be primarily on feedstocks near metropolitan centers addressing supplies at various population densities.

Preliminary Economic and Market Analyses for Advanced SWPO Gasification Systems. A preliminary economic analysis will be performed to evaluate the life cycle cost of the selected advanced SWPO hydrogen gasification system. The analysis will include estimates and forecasts of biomass fuel costs, system capital, operating and maintenance costs (as provided by General Atomics), net hydrogen production costs over time, potential credits, and/or byproduct revenue streams. A preliminary market analysis will be performed to better define the potential for deployment of advanced SWPO gasification systems. National and regional markets may be considered, although emphasis will be placed on California as an ideal representative market for the proposed approach.

Assessment of Biomass Gasifiers. A survey and assessment of biomass gasifiers will be performed to establish a comparative database for SWPO. The assessment will determine what gasifiers are currently or recently in operation, and will tabulate key parameters, e.g. T, P, feedstock, steam/feed ratio, hydrogen production, char formation, etc. The purpose of the assessment is to assemble performance data in a consistent format that will allow comparative analysis of different gasifiers.

Assessment of Transportation-Grade Ethanol Life Cycle Cost. Transportation-grade ethanol has become a thriving business in recent years in the United States. The corn-to-ethanol lifecycle-cost (LCC) is useful as a comparative model for other feedstocks and processing methods. An assessment of the corn-to-ethanol LCC will be performed to identify common cost drivers for other feedstocks, and to define barriers to the development biomass gasification using SWPO.

Update SWPO Development Plan. The results of these special studies will be used to update the SWPO development plan presented in the Phase I final report. The technical information from Tasks 1 and 2 will also be used in revising the development plan, and in defining the requirements for Phase III.

\section{Schedule}

Figure C-2 presents the schedule for proposed Phase II activities. Phase II start is assumed to occur January 1, 2003. 


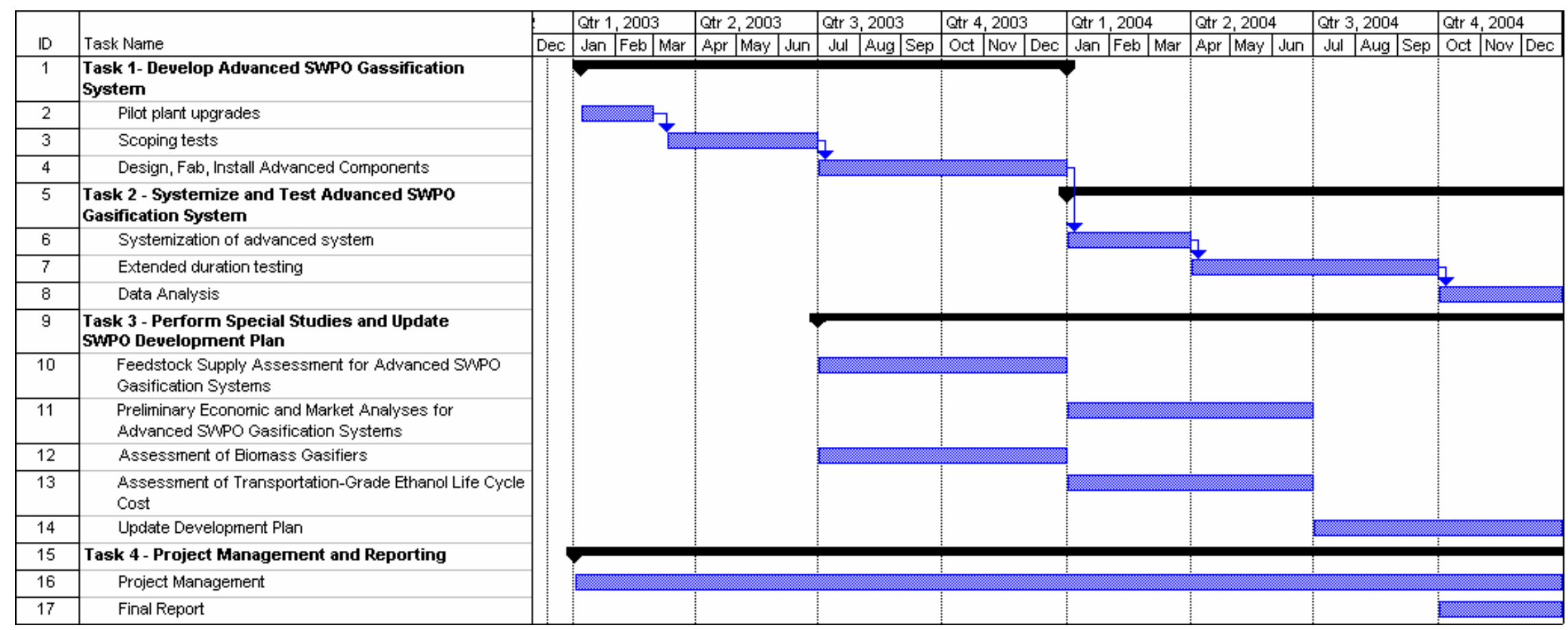

Figure C-2. Schedule for SWPO Development Phase II. 


\section{PHASE III - SYSTEM INTEGRATION AND DESIGN}

\section{Work Scope}

Phase III, System Integration and Design, involves detailed design and long-lead procurement of equipment for the reduced-scale demonstration of Phase IV, including industrial $\mathrm{H}_{2}$ separation and storage systems. The piping and instrumentation diagram will be prepared and the process control logic developed. Equipment drawings and specifications will be prepared and procurement of long-lead equipment initiated. Supporting tasks, including a safety evaluation, RAM studies, and required permitting activities will be carried out. Economic estimates will also be revised to be consistent with the experience of the Phase II program to ensure that the technology continues to meet the criterion of economic viability.

\section{Task 1 - Systems Analyses}

Perform systems analysis studies:

1. Perform safety analysis to define hazards, hazard categories and design changes required to mitigate unacceptable hazards.

2. Perform reliability, availability, and maintainability (RAM) analysis.

3. Prepare updated economic analysis.

\section{Task 2 - System Design}

Prepare 5 tpd SWPO system equipment drawings and specifications, and define facility and support requirements:

1. Define P\&IDs and control logic diagrams.

2. Prepare equipment drawings and specifications.

3. Specify vendor-supplied equipment and components, including steam reformer, PSA, and hydrogen storage tank.

4. Define facility upgrades and support needs.

5. Prepare fabrication/installation drawings.

\section{Task 3 - Equipment Procurement}

Initiate procurement of long-lead equipment.

\section{Task 4 - Permitting}

Initiate permitting activities to install and operate the 5 tpd SWPO system at a wastewater treatment plant.

\section{Schedule}

Figure C-3 presents the schedule for proposed Phase III activities. Contract award is assumed to occur January 1, 2005. 


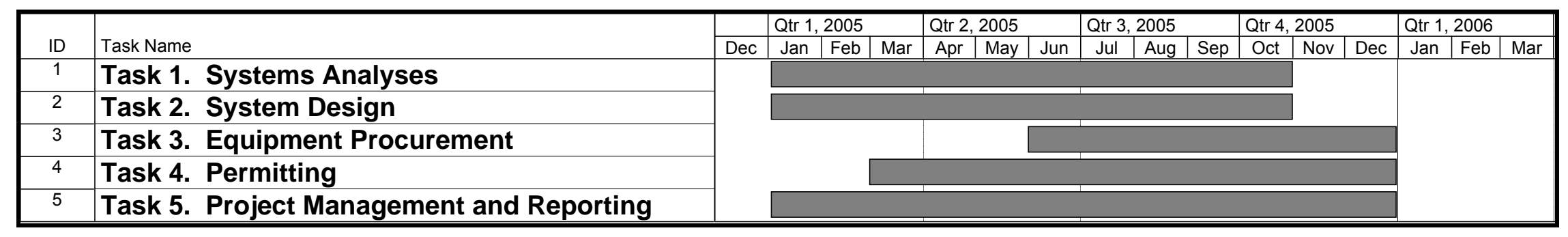

Figure C-3. Schedule for SWPO Development Phase III. 


\section{PHASE IV - REDUCED-SCALE DEMONSTRATION OF 5 TPD SYSTEM}

\section{Work Scope}

Phase IV, Reduced-Scale Demonstration of 5 tpd System, comprises a near-commercial demonstration of the integrated SWPO technology. The reduced-scale unit will process about 5 tpd of sewage sludge plus additional trap grease, approximately one-eighth the size of the commercial unit envisioned. The system will undergo shakedown and systemization testing with simple feeds. Integrated system testing with sewage sludge and grease trap waste will then be carried out over a period of several months, followed by extended testing to verify longterm operability. A successful demonstration at this scale should be sufficient to attract municipal/industrial partners for a commercial-scale demonstration.

\section{Task 1 - Procurement}

Procure remaining system components and equipment:

1. Acquire balance-of-plant equipment and materials.

\section{Task 2 - System Assembly}

Integrate the SWPO subsystems and prepare facility:

1. Assemble subsystems for integrated operation.

2. Program software for integrated operations.

\section{Task 3 - System Checkout at GA}

Testing of all system components:

1. Perform SWPO checkout tests with simulants.

2. Perform SWPO checkout tests with sewage sludge and grease trap waste.

\section{Task 4 - Integrated Testing at Municipality}

Relocate SWPO system to a municipal wastewater treatment plant, and perform extended demonstration testing, verifying economic hydrogen production and system reliability:

1. Complete required permitting.

2. Prepare municipal facility for SWPO system.

3. Install SWPO system at municipal facility.

4. Perform extended duration tests with sewage sludge and grease trap wastes.

\section{Schedule}

Figure C-4 presents the schedule for proposed Phase IV activities. Contract award is assumed to occur January 1, 2006. 


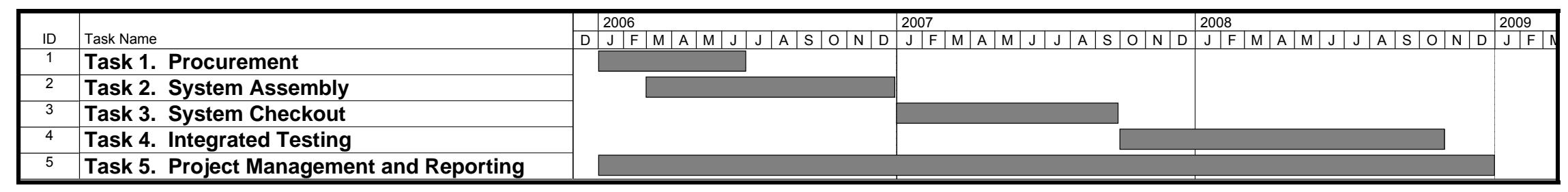

Figure C-4. Schedule for SWPO Development Phase IV. 


\section{Market Analysis}

\section{Market Definition}

The near-term market for SWPO technology is the processing of biomass streams for which substantial disposal costs are currently involved. Leading candidate wastes include sewage sludge, municipal solid waste, animal manures, pulp and paper mill sludges; agricultural/food processing wastes such as bagasse, wheat straw, potato peelings, corn stover, and fruit processing residues. These wastes are characterized as having high moisture content and some have toxic or corrosive chemicals that are difficult to handle by more traditional gasification methods. Potential low or negative cost, high heating value feedstocks include grease trap waste, waste plastic and rubber, waste oil, coke, and low-grade coal.

A municipal treatment plant serving a city of 1 million residents will generate about 100 tpd of digested sewage sludge solids (Bastian, 1997). Undigested sewage sludge solids are produced at approximately double this rate. A city of 200,000 residents can thus support a SWPO plant of the size proposed for initial commercial installations (about $40 \mathrm{tpd}$ ) when operating on undigested sewage sludge solids. To define the prevalence of this size community, Table C-1 summarizes city populations in the U.S. taken from the 1990 census. Many of the cities listed will have multiple treatment facilities, and the metropolitan/suburban areas surrounding these cities may well double the number of candidate sites. Thus, there are estimated to be several hundred municipal plant sites in the U.S. where a 40 tpd or larger SWPO system could be installed. It should also be noted that the size of the sewage sludge market is increasing as more stringent disposal regulations have come into effect over the past 25 years.

TABLE C-1. CITY POPULATION IN THE UNITED STATES

\begin{tabular}{|c|c|}
\hline Population & Number of Cities \\
\hline $100,000-300,000$ & 156 \\
$300,000-600,000$ & 33 \\
$600,000-900,000$ & 6 \\
$900,000-1,200,000$ & 6 \\
$>1,200,000$ & $8^{a}$ \\
\hline
\end{tabular}

Earlier this year a wastewater treatment plant survey was carried out by GA in conjunction with San Diego State University (SDSU). Utilizing the world-wide web, electronic surveys were delivered to about 1000 wastewater treatment directors. About 120 responses were received. A full report on the survey has been included as Appendix D. 
The survey results confirm that there are numerous potential customers with sludge disposal costs of $\$ 200 /$ ton or more. These municipalities are ideal candidates for initial market penetration.

Other biomass waste streams exist today that are amenable for gasification and hydrogen production. There are approximately 160 pulp mills operating in the U.S., with sludge generation rates ranging from less than 5 tpd to about 150 tpd, with a median sludge generation rate of about 20 tpd (Blosser and Miner, 1986). Data on agricultural and industrial sludges have not been obtained for this plan, but could possibly add several hundred candidate sites. Municipal solid waste generation rates are 5 to 10 times those of sewage sludge, and serve as a future growth market requiring additional pretreatment steps and refinements for handling toxic and corrosive constituents. But these factors are again well-suited for the SWPO process. In industrialized countries worldwide, sales opportunities from just sewage sludge, pulp, and agricultural wastes number in the thousands. SWPO ultimately offers a means of closing the loop on mankind's generated biomass wastes, while deriving additional energy and environmental benefits.

\section{Customer Profile}

Wastewater treatment facilities are the likely initial customers for SWPO systems. With few exceptions, they have established equipment and practices for the primary and secondary treatment of sewage sludge. However, because of continually escalating disposal costs for residual sludge solids, many plants have an ongoing interest in alternative disposal techniques. The wastewater facility will have to be amenable to becoming a hydrogen supplier or electricity provider, either directly with an owner-operated unit or indirectly through an outsource agreement with a commercial contractor to operate a system on their site. Thus, finding appropriate locations for the initial systems is a key factor.

\section{Competition}

In the United States, $54 \%$ of the municipal sludge production is disposed of by land application to cropland, forests, reclamation sites, lawns, park land, etc. Approximately $18 \%$ is disposed of in landfills and $19 \%$ is incinerated (Bastian, 1997). As confirmed by our recent market survey with SDSU, SWPO should be economically attractive for a substantial fraction of municipal treatment plants. While land application is viewed as an environmentally acceptable disposal method, concerns about low levels of pathogens and heavy metals continue to push land amendment to more rural areas.

A brief search of the patent literature indicates a number of proposed uses of sewage sludge other than as a soil conditioner, such as a raw material for the manufacture of fuels or chemicals (the same general idea as anaerobic digestion), an additive in the smelting of ferrous materials, use as a fire suppressant, fuel for cement manufacture, an additive to road asphalt, and a bioremediation agent. None of these looms large in the current planning of wastewater treatment facility operators. 
Conceivably, gasification methods other than SWPO may be compatible with the processing of sewage sludge. But the high moisture content and heavy metals content exacerbate problems of sewage sludge processing by other gasification methods. SWPO is uniquely suited to wet, dirty biomass feeds, and may be the only cost effective gasification method for low and negative value municipal wastes such as sewage sludge and grease trap wastes.

\section{Risk}

The economic analysis for SWPO of sewage sludge and grease trap waste showed favorable (even competitive) hydrogen production costs over wide ranges of key parameters, including financing during the capital cost recovery period. However, an extended time frame for payback on a first-of-a-kind technology may cause reluctance on the part of the potential users, even though similar payback periods are common for large, capital-intensive systems. In this regard, the fact that the initial customer base is the public sector may be a significant advantage. Our discussions with wastewater treatment plant personnel indicate that there is less concern with return on investment if the project meets a perceived public need. Furthermore, the stability of public entities allows access to low-rate long term financing such as bond issues.

Significant political barriers to the implementation of SWPO are not anticipated. In fact, implementation of the technology is expected to be promoted and even partially subsidized by local, state and federal government organizations. SWPO technology has environmental advantages that will likely attract public support.

Following successful demonstration testing, SWPO Systems will begin promotion and sales of full-scale commercial units. The primary hurdle to overcome at this stage is likely to be the plant capital cost and its recovery. Financial backing will be required from the end user or an industrial, financial, and/or governmental partner. A consortium of interested Government and commercial entities might be the ultimate vehicle for financing the first few plants, much like other utility providers. Thus, the focus for the company will be to bring in other interested parties.

\section{Identification of Barriers and Potential Solutions}

A number of potential barriers have been previously described in terms of technology development requirements. Assuming these requirements are met, there remain potential barriers with respect to displacement of existing disposal technologies with a first-of-a-kind technology with little or no prior experience. This and other potential barriers are considered in this section.

By virtue of its long history, municipal wastewater treatment is a well-established industry. Many wastewater treatment plant operators are likely to be risk averse toward a new technology given that they have existing plants and sewage sludge disposal practices that are providing satisfactory service. To gain a better appreciation of existing practice and potential technical barriers, discussions were held with Encina personnel and other regional wastewater facility operators. The Encina plant, located approximately 10 miles north of $\mathrm{GA}$, treats sewage for a population of approximately 250,000 residents. It generates $80 \mathrm{tpd}$ of digested sewage sludge solids (SSS) at $19.5 \%$ solids content (16 bone dry tons (bdt) per day) and pays about \$38/wet 
ton $(\$ 200 / b d t)$ for hauling to Yuma, Arizona for land farming. This is a typical value for Southern California wastewater treatment facilities (Los Angeles, Orange County, San Diego).

In order to displace existing practices, SWPO will have to demonstrate among other things that it is as reliable as conventional techniques. This fact can only be established by an extensive operating history. To address this issue, it is anticipated that the initial commercial-scale units will be installed at large existing wastewater treatment facilities with treatment capacities of 100$200 \mathrm{tpd}$ of mixed SSS. The SWPO commercial-scale unit would process a side stream of 40 tpd of SSS. With this approach, should SWPO technical problems be encountered or process modifications be desired, the treatment works can fall back on existing facilities and still fulfill its obligations to the community. As the SWPO technology matures, it may eventually be considered as the sole sewage sludge treatment method for new or renovated treatment works.

There are no apparent environmental barriers to the SWPO technology. Water and solid effluents from the SWPO system will be cleaner than those resulting from conventional wastewater processing. Carbon dioxide in the flue gas is a greenhouse gas, but this carbon is already active in the global carbon cycle and does not provide any net transfer from sequestered carbon (coal, oil, gas reservoirs, clathrates and rocks) to the atmosphere. In addition, the relatively low SWPO operating temperature results in minimal emissions of nitrogen oxides and sulfur oxides. By the same token, land application of treated sewage sludge solids is generally regarded as safe and environmentally acceptable for non-food crops, providing fertilization, aiding reclamation of disturbed land, and avoiding water pollution (ocean dumping) and air pollution (incineration), but requiring truck transportation and additional fossil-fuel energy consumption (see the Water Environment Federation web site at www.wef.org). Thus, SWPO is positioned as a "green" technology, with substantial environmental advantages over existing sludge disposal methods.

A concern sometimes expressed with regard to SCW systems is the combination of elevated temperatures and pressures. However, a number of highly mature industrial technologies utilize a similar range of conditions. Comparable temperature and pressure conditions are found in thousands of power plants worldwide, as well as in the chemical processing industry where the two most common applications are ethylene polymerization and ammonia synthesis. Wet air oxidation, the forerunner of SCWO, is practiced at over 200 locations worldwide. SCWO, the sister technology of SWPO, has been under development for more than 20 years, during which time an excellent safety record has been established. It is likely that a commercial SCWO system treating a complex waste will be in operation within the next several years, lending credibility to the viability of SCW processes. Thus, there is substantial industrial experience with high temperature and high pressure processes that have excellent safety records, with growing SCW applications among them.

\section{Marketing Plan}

\section{Sales Strategy}

Sewage sludge represents a cost liability to wastewater treatment facility operators despite the well-established practices and benign or beneficial disposal methods. The focus of the SWPO 
marketing effort will be to highlight the production of hydrogen and energy from sewage sludge, allowing facility operators to reduce operating expenses near-term by avoiding sewage sludge disposal costs, and lessen or eliminate long-term operating expenses related to secondary treatment of waste. Successful operation of the 5 tpd reduced-scale SWPO system at a regional wastewater facility will provide an operational data base that can be applied to the marketing effort. The reduced-scale data base will build confidence in the reliability and economic performance of commercial-scale SWPO systems and provide the necessary customer input for design of the commercial systems.

\section{Advertising and Promotion}

The near-commercial operation of the 5 tpd system at a regional wastewater facility will serve as the single most important means of promoting (through demonstration) the SWPO technology. Other wastewater facility operators will be invited to observe first-hand the on-site operations. Video tapes of the operations will be made available, together with a worldwide web site and interactive analysis with potential clients. The marketing effort will be aided by the publication of technical articles in trade journals, and presentations at trade and professional conferences.

\section{Financial Plan}

Total estimated costs for Phases II through IV of the GA/DOE SWPO development program and the follow-on near-commercial reduced-scale demonstration are summarized in Table C-2. More detailed cost estimates will be provided the start of each phase of the work.

TABLE C-2. BUDGETARY ESTIMATE FOR PHASES II THROUGH IV

\begin{tabular}{|lc|}
\hline Phase & Budget (\$) \\
\hline Phase II, Technology Development & $1,200,000$ \\
Phase III, System Integration and Design & $3,500,000$ \\
Phase IV, Reduced-scale Demonstration & $2,500,000$ \\
\hline Total for all remaining phases & $7,200,000$ \\
\hline
\end{tabular}




\section{Process Economics}

Section 5.1 previously presented an economic analysis for a commercial-scale system. The economic analysis determined that a broad range of conditions exist for which SWPO can be used to produce hydrogen at competitive prices. Key factors include the following:

1. Biomass sludge credit - Sewage sludge is particularly desirable as it frequently has a negative value of $\$ 200 / \mathrm{bdt}$ and higher. Other biomass feedstocks are feasible if other parameters such as financing terms and availability of high heating value waste are favorable.

2. Steam credit - Steam credit is a significant offset of operating costs. Much of the steam can be available at 1200 psi if desired.

3. High heating value waste cost or credit - Grease trap waste is particularly desirable as it frequently has a negative value and is available in the same locations as sewage sludge.

4. Capital financing rate and term - Particularly favorable financing terms may be available as the customer is a municipality as opposed to a commercial entity.

5. Ratio of high heating value waste to biomass - High heating value waste leads to a higher proportion of hydrogen production.

6. Plant size - A plant treating 40 tpd of swage sludge solids is economically competitive over a broad range of conditions.

We envision that the initial commercial-scale 40 tpd SWPO system for hydrogen production can be ready for commercial deployment in approximately eight years, i.e., 2011. This assumes that all key technical issues described above have been resolved in near-commercial testing of the 5 tpd pilot plant at a wastewater treatment facility, and an initial commercial customer has been identified. Design of the $40 \mathrm{tpd}$ commercial system would commence during the latter part of Phase IV, and design and construction would be completed during the subsequent commercial contract.

\section{Technical and Financial Requirements for Manufacturing Capability}

The technical requirements foreseen as necessary to achieve commercialization are essentially those described in the Development Plan of Section 5. For comparison purposes, over $\$ 200$ million has been spent to date by the private and public sectors on SCWO technology, which is characterized as at the stage of incipient commercialization. Several commercial SCWO plants are currently operational for treatment of various waste streams. Several SCWO plants are expected to be built in the Government sector, as secondary treatment for waste derived from the destruction of chemical weapons. 
Much of the knowledge base developed for SCWO is directly transferable to SWPO.

Nevertheless it is likely that additional investments will be required to reach the point at which a wastewater entity is willing to back a first commercial plant. Phases II through IV call for over $\$ 5.5$ million of GA and DOE funding. This initial investment represents a "success-oriented" estimate, i.e., it assumes that the technology development requirements are achieved and that no major obstacles are encountered and that continuing developments in SCWO will be a no-cost benefit to SWPO. In a less optimistic scenario, developmental hurdles may be encountered, and additional follow-on funding will be required. Industrial partners may be required to provide the additional funding necessary to bring the SWPO technology to commercial status. 


\section{APPENDIX D}




\section{SURVEY OF MUNICIPAL SEWAGE TREATMENT PLANTS}

GA commissioned a market survey and analysis of wastewater treatment plants which was carried out by graduate students at the San Diego State University (SDSU) School of Business. The objective of the study was to identify near-term wastewater treatment plant clients and to better define market drivers and client needs. A world wide web-based survey was conducted across the U.S. and analyzed to determine the commercialization potential of its SCW technology. The results of the study are presented in this appendix. 
General Atomics

Consulting Report on

Supercritical Water Oxidation: Application to Municipal Biosolids Waste Disposal

\author{
Prepared By \\ Lisa Crane \\ Manjit Gill \\ Scott Gunther \\ Vijay Shirsathe
}

\author{
Submitted for Client Approval \\ On \\ The Twentieth Day of August \\ In the Year Two Thousand Two.
}

Presented in partial fulfillment of the requirements for the Masters of Business Administration Degree Graduate School of Business Administration

San Diego State University

Don Sciglimpaglia, Ph.D.

D-3 
Business Consulting Program

College of Business Administration

San Diego State University

5500 Camponile Drive

San Diego CA $92182 \cdot 7746$

TEL $619 \cdot 594 \cdot 3901$

FAX: $619 \cdot 594 \cdot 3653$

\section{SDSU MBA Business Consulting}

Final Report Acknowledgment
I, (Client's Name) of (Name of Firm)

do hereby acknowledge receipt of a copy of the final consulting report that was prepared by the student consulting team from the San Diego State University College of Business Administration.

The team has met and discussed with me the findings of this report. Whereas this report does address the areas of management concern described in the engagement letter, and the team's findings represent valid considerations of these areas that are of utility to our management, this acknowledgment does not necessarily mean that I am in complete agreement with the recommendations.

(Client's Signature)

(Team Member Signature)
(Date)

(Team Member Signature)

(Team Member Signature)

(Team Member Signature) 


\section{Engagement Letter}

Mr. Lindsey Bierer

Business Development

Advanced Process Systems Division

Advanced Technologies Group

General Atomics

3550 General Atomics Court

San Diego, CA 92186-5608

Mr. Bierer,

On behalf of our student team, I would like to thank you for the opportunity to work closely with you and General Atomics on this project. Among the different program alternatives that were offered, this chance uniquely offered an exciting opening with a well-established international firm. This letter is intended to reflect our understanding of your organization, identify the issue at hand, and clarify the scope of work necessary to complete this project. Chiefly, our goal is to offer valuable market segmentation information for the SCWO process through a market survey instrument. To accomplish this primary objective, three key phases will be implemented:

1) Initiation of a nationwide e-mail market survey for wastewater treatment operators.

2) Collection and analysis of the results.

3) Presentation of study report to key individuals at GA.

\section{Background Information for General Atomics}

It is important to first show that the student team has been given a clear impression of the mission of General Atomics. The opening statement to the corporate website describes the nature of the company: 
General Atomics was conceived in 1955 at San Diego, California for the purpose of harnessing the power of nuclear technologies for the benefit of mankind. General Atomics' basic research into fission and fusion has matured into competence in many technologies, making GA and its affiliated companies one of the world's leading resources for hightechnology systems development ranging from the nuclear fuel cycle to remotely operated surveillance aircraft, airborne sensors, and advanced electric, electronic, wireless and laser technologies.

Following this stated purpose of using high-technology innovations towards the end of benefiting mankind, Supercritical Water Oxidation (SCWO) has been shown to be an effective alternative to incineration for the destruction of hazardous wastes. General Atomics identifies their company as the leader in the development of SCWO. Initially targeted towards military wastes, the SCWO process has been developed to treat civilian issues such as disposal of municipal sewage sludge. Cost estimates currently under investigation by General Atomics show the process to be competitive with other disposal methods of sewage sludge. Coupling the process with eliminating a costly anaerobic (non-oxygen involved) step in sludge treatment, the savings for municipalities that implement SCWO potentially could be tremendous.

\section{Identification of the Key Target}

While the cost advantages of the process are fairly clear, information regarding the size, location, and overall demand for SCWO technology appears to be unorganized, at best. Although the process appears to be of obvious significant value to municipalities across the nation and beyond, identification of the best primary targets of focus has not yet been made evident. Thus, the primary issue for this project is to get reliable data, quickly and accurately, through an appropriate market study.

\section{Project Objectives}

Overall Project Goal: Garner deliverable information via an e-mail survey to be analyzed and presented to the client as a market study. 
Objective \#1: Initiate e-mail survey.

$>$ The student group will fine-tune a prepared paper-based survey and convert it to an electronic version that can be distributed over the internet

$>$ Test survey on local, easily approachable municipal waste managers, as available, for appropriateness, relevance, and accuracy

$>$ A list of appropriate contacts will be compiled from available databases of wastewater treatment organizations, among other sources

$>$ Distribute survey via e-mail with instructions for completion

$>$ Offer incentive to fill out survey, namely feedback on the results across the industry, contingent upon their participation

\section{Sampling Process:}

The crux of this step is gaining access to (and feedback from) the key decision-maker at each site location. This is essential because that person will be one of few to be in a position to answer the very specific questions posed by the survey. The project team members are interested in collecting information solely from the key decision-maker at each site. Since the information gathered through secondary channels and existing databases is not anticipated to give exact titles and roles for individuals, an initial contact e-mail will be sent asking the addressee to forward the message to the key person. This premise makes some admitted assumptions:

1) The addressee will actually read the e-mail before trashing a message from an unknown source.

2) S/he will have incentive to forward the tool into the right hands.

3) When the right person does get the survey, s/he completes it promptly.

Steps will be taken to ensure that, to the best of our ability, we will avoid an unexpectedly low rate of return for this survey. The initial e-mails will be addressed from a student account, appealing to the academic nature of the situation and giving credibility to the report. The report, itself, should be clear enough to be an appreciable 
reward for participation. Utilization of online survey tools and a concise survey should also help to both increase overall response rates and expedite response times.

Should response rates be so low that it impacts the amount of significant data that does become available, some contingency plans have been put into place. Marrying the phone and e-mail contact methods has been mentioned, as has seeking other methods of delivery. At the far end of the imaginative scale, placing a team member at a known industry convention with surveys in hand might yield the most productive data of any alternative, but at considerable cost.

Objective \#2: Analyze results.

Summarize results of survey using resources of online survey tool

$>$ Create tables with key findings

$>$ Use results to identify striking factors, tendencies, and significant data

\section{List recommendations for strategic marketing}

\section{Analysis Process:}

The online survey tool should make this step relatively simple, with import/export capabilities built in to the service. The $\$ 19.95 /$ month rate for www.surveymonkey.com entitles users to advanced tabulation capabilities and tracking information, which our team fully intends to take advantage of. Charting and table creation are also offered as services under the agreement. These will be used to show which areas would lend themselves most easily to opening the market for SCWO, or if the idea has some unforeseen drawbacks.

Objective \#3: Prepare and deliver report to clients.

As stated, deliver analysis to General Atomics contacts 


\section{Reporting Process:}

The report will be submitted to the client in written and verbal form by the twenty-third of August. 


\section{Preliminary Schedule \& Deliverables}

The objectives stated above will be completed and delivered by August 23, 2002. The table below outlines the estimated start and completion dates of necessary tasks:

\begin{tabular}{|l|c|l|}
\hline Iasle & Involyed & Cstimated \\
\hline Web site completed. & all & $7 / 2 / 2002$ \\
\hline First e-mail sent. & M & $7 / 8 / 2002$ \\
\hline $\begin{array}{l}\text { Follow-up initiated (as } \\
\text { necessary }\end{array}$ & all & $7 / 12 / 2002$ \\
\hline All Results tabulated. & all & $7 / 23 / 2002$ \\
\hline $\begin{array}{l}\text { Survey tabulation sent to } \\
\text { respondents. }\end{array}$ & M & $7 / 26 / 2002$ \\
\hline Draft report prepared. & L,V,S & $7 / 30 / 2002$ \\
\hline Final report prepared. & all & $8 / 6 / 2002$ \\
\hline
\end{tabular}

* Members: (L)isa, (M)anjit, (S)cott, and (V)ijay. 


\section{Conclusion}

With these objectives met, our student team will deliver information that can be utilized by the client to formulate a market strategy. Obviously, this culminating experience is an opportunity the student team has looked forward to since the beginning of our tenure at SDSU, as it marks the last great hurdle between the group and graduation. We look forward to crossing the finish line in winning style for everyone involved.

Very Respectfully,

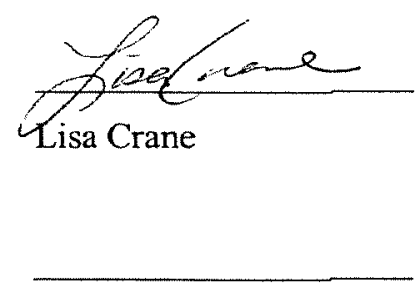

Manjit Gill
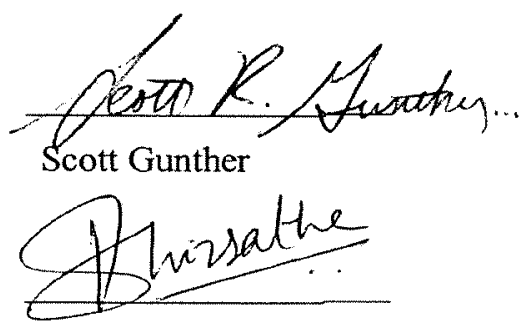

Vijay Shirsathe

Your signature is requested to signal agreement on the project objectives and deliverables as stated.
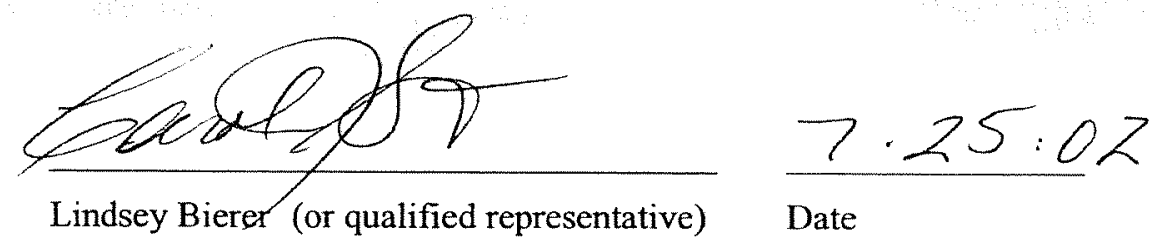

Date

Business Development Consultant, General Atomics 
Table of Contents

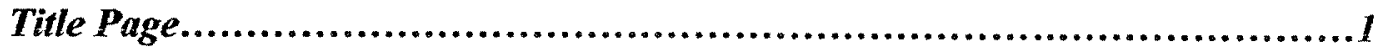

Client Acknowledgement Form.................................................... 2

Letter of Engagement..................................................................

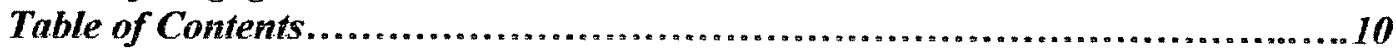

List of Tables and Charts.............................................................1!

Appendices Table of Contents...................................................

Executive Summary.............................................................

Introduction.....................................................................16

Backgrownd ...................................................................18

Problem Statement..................................................................23

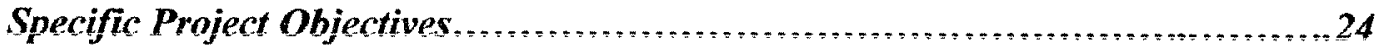

Project Methodology............................................................26

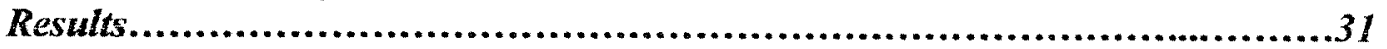

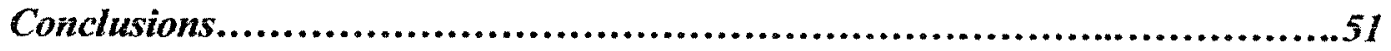

Recommendations...............................................................54 
List of Tables and Charts

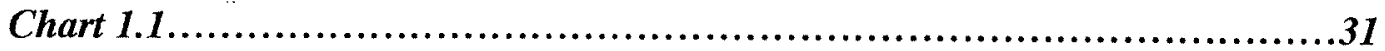

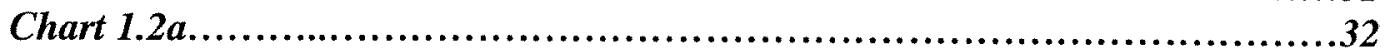

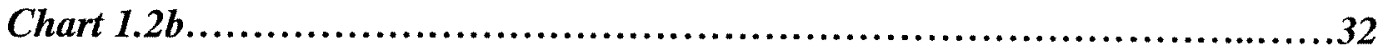

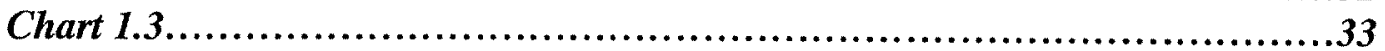

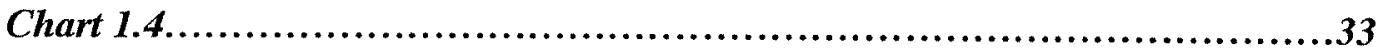

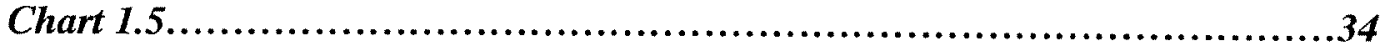

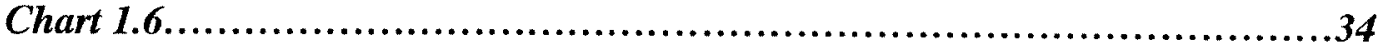

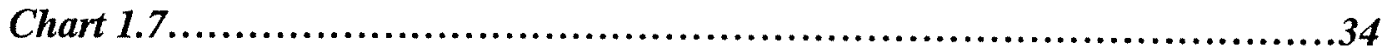

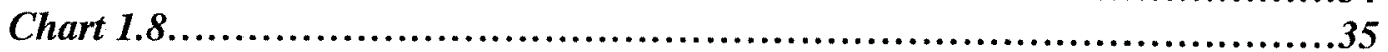

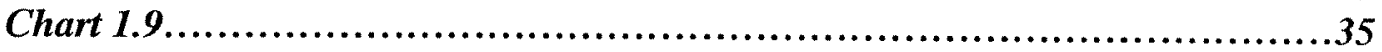

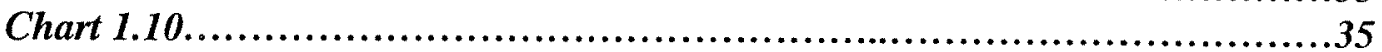

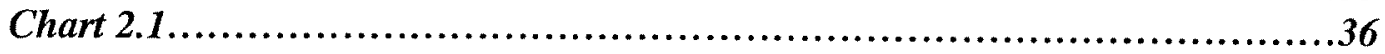

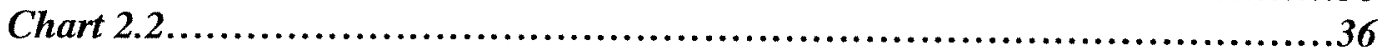

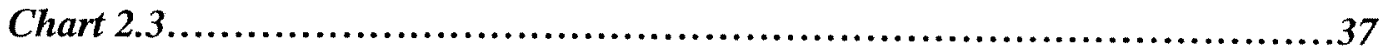

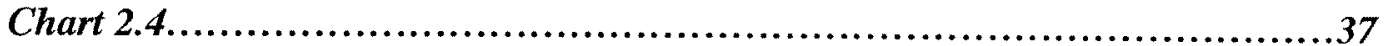

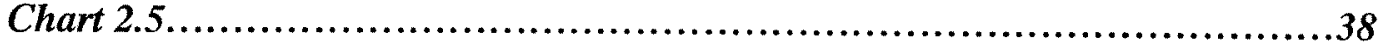

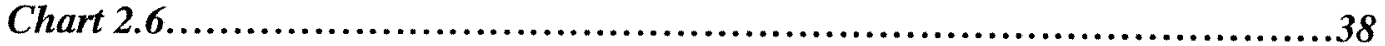

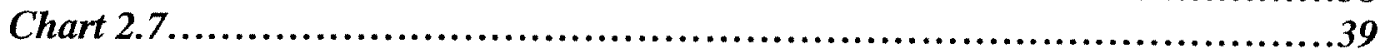

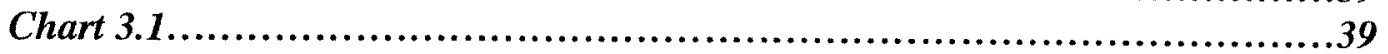

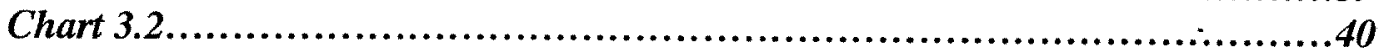

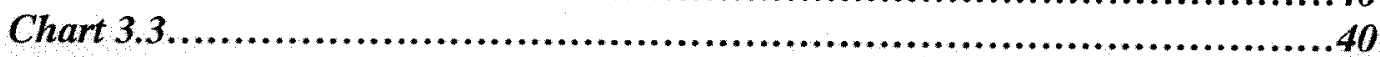

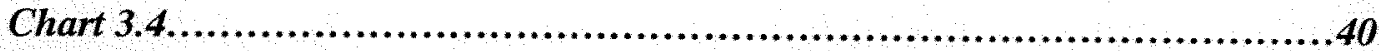

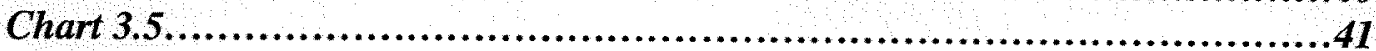

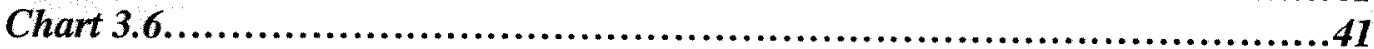

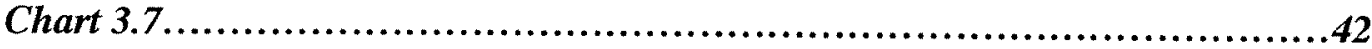

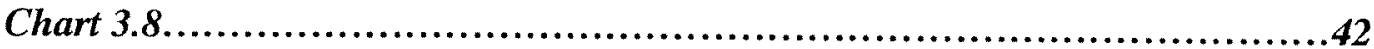

Chart 3.9..................................................................43

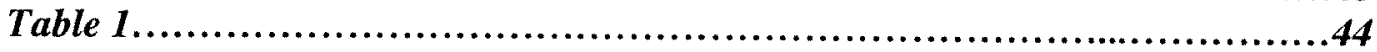

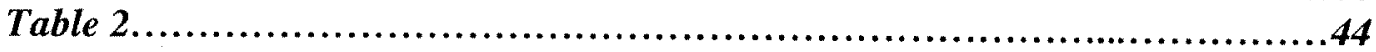

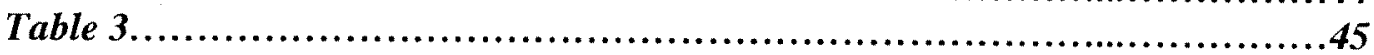

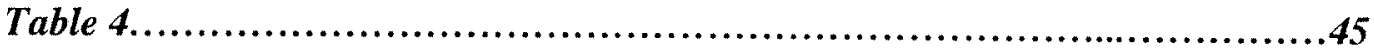

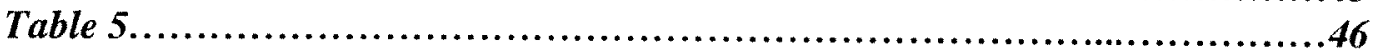

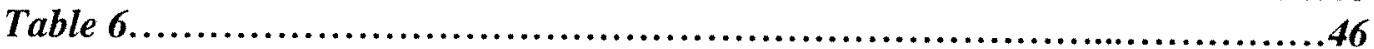

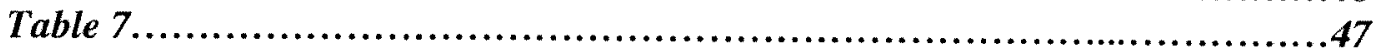

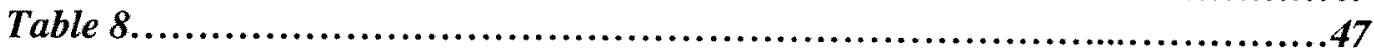

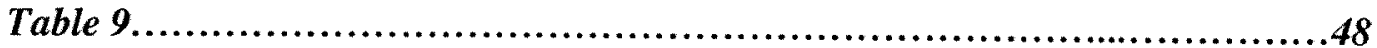

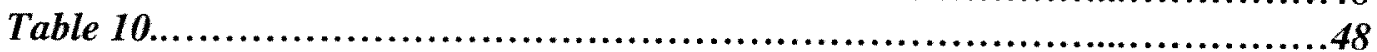

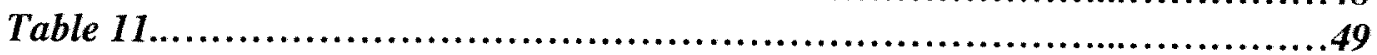

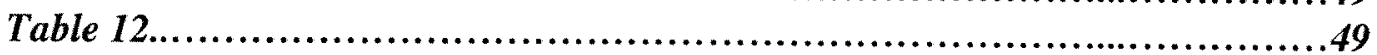

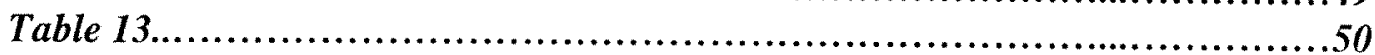

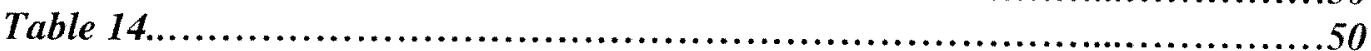


Appendices Table of Contents

A. Maps of Respondents........................................................55

B. E-mail Correspondence.......................................................559

C. Web-based Survey Questionnaire............................................63

D. Selected Open-Ended Questions.............................................67

E. Service Agreement with surveymonkey.com...............................73

F. References.............................................................. 76 


\section{Executive Summary}

This study consisted of a web-based survey of 967 director-level employees of Municipal Public Works across the United States and parts of Canada. The survey was delivered through a mass e-mail message to individual contacts found through research on the Internet. The purpose of the study was to collect data and create a market report. Respondents were asked to fill out the survey, which was divided into three sections. A total of 121 responses were received over the course of the survey.

The first section of the survey contained questions regarding the current state of their wastewater treatment facilities. A full $66 \%$ of respondents indicated that there was only one treatment plant in their organization. The majority of plants operated as both primary and secondary treatment centers as opposed to just primary treatment centers. The majority of plants were over 15 years old $(70 \%)$ and the overall population served was generally less than 100,000 . Total treatment capacity for the plants averaged 22.75 million gallons per day and the average total biosolids capacity of all plants was 118.49 in dry tons sludge per day. Capacity numbers currently for the average plant are 107.49 dry tons sludge/day, and are expected to remain about the same for the next 10-20 years. The last question from this section was used to determine how financing was most commonly done, with municipal bonds and increased sewer rates coming in on top with $66 \%$ and $62 \%$ respectively.

The second section quantified the biosolids processing capacities. The most common method for dewatering was belt filters ( $40 \%$ ) followed by gravity belts and centrifuge. Staffing was on a 24 -hour basis only $35 \%$ of the time and digester methane was usually either flared (47\%) or used for digester heating (49\%). System operation of the power generator had a ratio of $15: 1$ for plant staff to contractor help. Only $14 \%$ of the respondents claimed that they had industrial neighbors that could use their by-products.

Section three was the last section of the survey and dealt with the biosolids disposal process. Over $76 \%$ of the systems had one or more biosolids disposal facilities. Land amendment was clearly the most common disposal method at $71 \%$ followed by landfill (28\%) and then composting (8\%). Current sludge disposal costs averaged $\$ 114.07$ although the median value is far below at $\$ 54$. Nearly half of the respondents were considering new methods for disposal. The significant driving forces for 
management were regulatory, disposal costs, and land shortage. More than half (56\%) of the respondents were interested in Super Critical Water Oxidation (SCWO) and a full $75 \%$ indicated that they would like to receive additional information on the technology.

Careful analysis of the results discussed above led the team to several informative conclusions. Judging from the exceptionally high response rate to the survey and from responses within the survey, it was inferred that there is significant interest in a new technology that can efficiently solve current municipal biosolids disposal problems. The state of the current facilities depicted by the survey suggested that a large percentage of the target market have relatively old facilities. Regulatory pressures and high disposal costs appeared to be the driving factors that cause municipalities to consider more costeffective and environmentally efficient disposal methods. All of these factors combine to indicate that the time seems to be right for a new technology such as SCWO to fulfill the market need mentioned above. We conclude that General Atomics can compete successfully in this environment given their considerable expertise and experience.

The student team also concluded that there were several indicators that marked tendencies for plants to be more interested in SCWO. These included plants that were (1) older than 30 years; (2) serving populations of 100,000-499,999 or over 1 million; (3) using gravity belts or centrifugation for dewatering; (4) employing five or more personnel; (5) using landfill or land amendment as disposal method; and (6) driven by regulatory forces or disposal costs.

The student group has several recommendations that came out of this market research. First, it is suggested that General Atomics actively pursue municipalities that fit the categories listed in the conclusions above. Those cities are shown to be more likely to have an interested in SCWO. By targeting plants that may already be interested, selling costs can be minimized and the target range can be focused. Second, it is recommended that General Atomics begin to educate the market about SCWO. Education will help bring attention to the technology as a viable alternative. The third recommendation is to suggest an alternative method for identifying potential customers. The current method was to begin sorting based on respondent interest. Unfortunately, survey results showed several respondents listed themselves as "uninterested," even though they would appear to benefit greatly from SCWO from a financial standpoint. 
This means that there is a portion of the market that could be swayed by informative selling techniques. By starting the sorting process from a financial benefit perspective, some more candidates may be found. Lastly, it is also recommended to carry out further analysis on the raw data collected through this survey. Several of the answers to openended questions gave good insight into the motivations of municipal directors, but were not able to be quantified and captured. Reading through this feedback will give General Atomics a better understanding of the potential customer. 


\section{Introduction}

Supercritical water oxidation (SCWO) is an emerging technology that promises an efficient and environment-friendly biosolids disposal method. This report comprises of market research that evaluates the market feasibility of this technology. The research was conducted via an Internet-based survey.

It is important is to stress the significance of the information that can be gleaned from a few people answering some questions for a student survey. An illustration was made in a recent article gracing the Sunday headline of a nearby newspaper, The Orange County Register, stating simply, "Sewage treatment on tap." Pat Brennan, a staff member of the Register, authored the article and clarified several of the issues involved.

The subject revolves around a single district in Orange County that serves approximately 2.2 million people in the area's region. These end-users are the beneficiaries of the current sewage system that exists and would all be affected if any policies were changed by the local elected officials who run the system.

Ecologically, the impact of the current system has come into question. Several of the beaches in the area have become polluted with high levels of biologics and the cause is unclear. Some experts suggest that the sewage treatment and its flow from off-shore release points is the culprit, while others believe the "plume" of treated sewage that is released several miles off-shore to be innocent of the crimes it is accused of committing.

Public perception is the vehicle that may decide how the cities affected will come to a conclusion on the best solution to this problem. Regardless of factual evidence, sometimes an idea is just too abstract for the common voter to accept. Brennan shows that upgrading the current system may do nothing to actually change the effects and contaminations, but simply installing them will allow the taxpayers and beachgoers alike to sleep a little easier, and allay some of their fears.

The most compelling factor is the money that is at stake. The numbers that are being discussed right now are that "it could take as long as 11 years and cost an estimated $\$ 423$ million, to be paid for by sewer rate hikes for home and business owners." If you realize that this is just for a single operation and that tens of thousands of similar situations exist around the nation, you can understand that this is BIG business! If 
supercritical water oxidation can be tailored to be a viable option for either eliminating pathogens, reducing costs (or both), there is clearly a great deal of opportunity available. This project is intended to give the client, General Atomics, enough information to determine whether there is money to be made using their technology. Blanketing the nation will paint a picture of the overall market and can make entering this market a confident move, or justify the decision to pursue other interests. 


\section{Background}

General Atomics (GA) is an industry leader in developing an efficient technology called Supercritical Water Oxidation (SCWO), which is used to treat a wide range of hazardous wastes. General Atomics would now like to commercialize this technology for widespread treatment of more benign waste applications. One such application would be the disposal of municipal sewage sludge in an environmentally sensitive and cost effective manner. Disposal of sewage sludge is costly for municipalities that do not have their own facilities and a capacity battle for those that do; furthermore, disposal options are decreasing while disposal costs are increasing.

Modern wastewater treatment plants utilize aerobic digestion of activated sludge as the primary treatment method for reducing biological matter in wastewater. This enables the water to be safely returned to the environment. Sewage sludge that accumulates from the water treatment process is often treated in anaerobic digesters to reduce the biological activity and quantity of sludge. Output from the anaerobic digestion process is methane General Atomics, which can be collected and used to produce heat and/or power, and residual sludge depleted of most of its biological activity. This sludge is thickened and de-watered in a centrifuge or belt press to a moist consistency that can be transported by truck to the disposal site.

SCWO is an efficient and clean alternative to traditional sewage sludge treatment and disposal methods. The SCWO system would be integrated into the overall operation of the wastewater treatment plant. The most cost-effective way to introduce SCWO into plant operations is to bypass the anaerobic digestion process and send the sewage sludge directly to the SCWO system. The sludge should first be thickened and de-watered to about $10 \%$ solids by weight. With sufficient recuperative heat recovery, this sludge concentration is sufficient to fuel the SCWO process, enabling efficient, cost effective and environmentally friendly destruction of the sludge. 
Cost studies are currently underway at General Atomics to estimate the SCWO treatment costs for disposal of sewage sludge. Current estimates appear to be competitive with other sludge disposal methods. Therefore, it appears that a potential market exists for the sale of SCWO systems to municipal wastewater plants for disposal wastewater treatment plants to destroy the sewage sludge in compliance with environmental requirements and at an overall cost savings.

\section{Market Situation}

This section attempts to paint the picture of the current market situation as it is currently understood. All of the information discussed below has been extracted from several documents published on various websites listed in Appendix F.

Solid Waste Management (SWM) planning by each municipality must take into account the following items:

- The total amount of municipal waste generated

- The amount of that waste stream to be controlled by the local implementing agency or agencies

- The method or methods selected to manage that portion of the waste stream

- The various collection, processing and disposal options available

- The extent to which some or all of those options are currently being provided and who the providers are

- The advantages and disadvantages of public ownership and control versus marketbased private sector completion

- The balancing effort of market forces brought about by a competitive process

- The environmental impacts of the various alternatives

- The cost associated with each alternative

The economics associated with any of those alternatives and regulatory forces heavily influence the planning process. The U.S. Environmental Protection Agency (EPA) has established a hierarchy of preferred SWM technologies. Many similar state 
and local guidelines or mandates can be found in state waste management acts. Most SWM hierarchies include the following alternatives in the decreasing order of preference:

- Waste reduction at the source

- Recycling and reuse

- Resource recovery

- . Land filling

In concert with this hierarchy, the management of Municipal Solids Waste (MSW) should focus on reduction, reuse, recycling, and energy-recovery and divert the waste from the least desirable option, land disposal. During the past decades municipal governments have invested in advancing from unregulated disposal of waste to a more controlled environment. The main focus of this transition has been to close uncontrolled land disposal sites and shift to more environmentally sound land disposal facilities.

Applying this trend to the treatment of biosolids, many municipal establishments have implemented various biosolids stabilization processes. Products of such processes are compost, liquid sludge, sludge cake, lime-stabilized biosolids, and thermally dried biosolids. Various markets for these products include compost, for horticultural and landscaping industries, application to agricultural lands, and site remediation. Markets for composted products are limited to high quality products, which must meet horticultural standards. The compost markets are limited, and over-supplied with other products such as green waste. Further, composted biosolids are distributed directly to the public, which increases the risk of pathogen infection if the composting process does not completely destroy the pathogens.

The markets for large volumes of stabilized biosolids are agriculture, and to some extent, site remediation. Sewage sludge used in agriculture also requires tighter concentration limits for heavy metals in the sludge and the possible inclusion of limits for persistent organics. Application rates of biosolids are determined by agronomic and contaminant application rates. Land application of Grade B stabilized de-watered cake is 
the least cost option, however the biosolids must be digested to reduce odor and vector attraction. Further, recent studies in Denmark indicate that the beef tapeworm may survive in de-watered cake treated lands for more than one year. The USA National Research Council in "Use of Reclaimed Water and Sludge in Food Crop Production, 1996" considers that the withholding period for animals after land application of dewatered cake should be reconsidered.

Incineration of biosolids is yet another alternative followed by some of the establishments. However, increasingly stringent requirements on air emissions impose huge barriers to this option.

Given this picture of the biosolids treatment methods deployed throughout the United States, the story of SCWO technology appears even more compelling. A few companies such as Chematur Engineering and Hydroprocessing LLC are currently attempting to market the SCWO technology for the treatment of biosolids. The advantages that SCWO holds over conventional methods can be described as follows:

- Complete destruction of sludge with minimal residuals

- No concentrated return streams

- Reduction of odor and noise

- Cost effectiveness (enhanced by the sale of benign byproducts)

- Overall improved wastewater treatment plant operations

\section{Market data}

Biosolids treatment plants or facilities for various municipalities appear to exist in different forms. Some of the forms are mentioned below:

- Public ownership and operation of all required equipment and facilities

- Public ownership and operation of collection equipment and contract for private operation of publicly owned transfer, processing (materials recovery, composting, waste-to-energy) facilities and/or disposal (landfill) facilities 
- Public ownership and operation of collection equipment and contract for use of privately owned and operated transfer, processing facilities and/or disposal facilities

- Private ownership and operation of all required equipment and facilities through service contract with the public sector

- Private ownership and operations of all required equipment and facilities through direct contracts between the individual generator and the private sector supplier

In general, sewage facilities have been categorized under SIC 4952. Corresponding NAICS number is 221320. D\&B Industry Report (see reference in Appendix F) for this SIC gives a brief financial overview of the market size. As of 2002, there are an estimated 1,863 total number of facilities employing 31,662 people. Total annual sales in the industry are reported in excess of $\$ 3,557.5$ million. Geographical distribution and detailed information regarding these 1,863 facilities can be found in the report. 


\section{Problem Statement}

The problem statement for this field study can be stated as follows.

Currently, there is a scarcity of market information with respect to several aspects of the municipal waste treatment market. Chiefly, (1) the general age and makeup of existing waste treatment facilities is unknown, (2) the driving forces in sludge management strategy have not been elucidated, and (3) the general interest in new technologies, such as SCWO, is also in question.

Along with the financial feasibility study that is currently underway, General Atomics must also define the appropriate target market within the $\$ 3.5$ billion sewage facilities market. Of the thousands of municipalities that exist today in the United States, no single process for wastewater treatment exists. Rather, each municipality must base their decisions on their own unique set of criteria. General Atomics' goal in determining an appropriate target market will be facilitated through an understanding of the various decision-making processes for municipalities and what similarities exist. In order to determine technology selection criteria and potential demand for SCWO technology, it is necessary to collect and analyze relevant market data from the decision-makers at these facilities. This type of primary research would assist General Atomics not only in target selection but may also point out areas where their technology could be tailored to better serve the market or even expand the market. 


\section{Project Objectives}

As discussed earlier, this project dealt with the market research for the municipal solid waste disposal industry. The desired goal was to collect as much data as possible on the state of the current MSW treatment facilities in order to find out whether a potential exists for introducing SCWO to this market. Based on past experiences, General Atomics had concluded that an e-mail-based survey was an appropriate methodology to conduct this research. However, after discussion with the SDSU student team and Professor Sciglimpaglia, it was determined that a web-based survey would be the most appropriate method for this market research due to the nature of the BA795 format, which was limited in both time and budget. Additionally, current web-based survey technology offered advantages over traditional survey methods, such as automatic data collection and basic data tabulation. Therefore, a web-based survey was conducted and the results analyzed in order to determine the commercialization potential of General Atomics' SCWO technology.

The primary objective was as follows:

Garner deliverable information via an e-mail survey to be analyzed and presented to the client as a market study.

In order to achieve the overall objective mentioned above, it was necessary to define several secondary objectives. These secondary objectives were helpful in setting up intermediate milestones and provided tangible measures of the overall progress of the project.

First, a survey questionnaire had to be prepared with assistance from General Atomics and SDSU professors. The questionnaire was formatted to be simple enough for the respondent to answer quickly, but detailed enough to get informative data. Finetuning this instrument was critical for the rest of the project to work effectively.

Assuming a $10 \%$ response rate and that about 100 responses were required for effective analysis, the student team built a nation-wide database of approximately $1000 \mathrm{e}-$ mail addresses. These addresses had to be from specific personnel (Director-level or 
above) for each municipality, since each Director would be one of the few people who could answer the questions accurately.

Another secondary objective was to conduct the survey with an ability to track responses in real time. Due to the limited amount of time available, it was crucial to monitor the response rate and take appropriate actions, such as reminder e-mails or phone calls if the 100 response pre-set threshold was not met. Fortunately, no further contacts were needed other than the primary emails.

Once the survey had enough of a response from the nationwide set of recipients, the goal was set to analyze results in light of the problem statement discussed earlier. Creating the summary of key findings for General Atomics' use allowed the student team to draw conclusions and test the validity of the work performed.

The final objective was to prepare and deliver a detailed report and summary presentation to General Atomics and San Diego State University. Recommendations for future actions will be made at this time. 


\section{Methodology}

The previous section delineated the overall project objectives and a number of secondary objectives that provided the student group with a roadmap in this study. This section describes the approaches and methods used to achieve each project objective.

The first step in this project was creating a survey that would to obtain the most relevant information from the respondents. General Atomics suggested structuring the survey into the following three general areas of interest:

(1) Wastewater facilities information - Questions in this section of the survey were targeted towards determining the current and future planned capacity of existing treatment facilities. This information is particularly helpful gaining an understanding of the size and age distribution of existing treatment plants. This section also determines overall population served, capital improvement financing methods and sewer rate charges.

(2) Biosolids processing information - Questions in this section reveal details regarding the current processing methods used by the existing plant. This information is intended to help General Atomics in gauging whether or not SCWO is a technically superior alternative for the respondent. Specifically, this section surveys the respondent in terms of solid levels currently attained, number of plant personnel, uses for digester methane, and if near-by industrial neighbors have a use for the byproducts created by SCWO.

(3) Biosolids disposal information - Questions in this section are meant to identify the number of biosolids disposal facilities in each system, the biosolids disposal methods used, sludge disposal costs, current consideration of different disposal methods, most significant driving forces in sludge management strategy, interest in different sludge disposal methods and more specifically, their interest in SCWO.

The web-based survey questions were created with the assistance of General Atomics management. A base set of survey questions was provided by General Atomics and fine-tuned by the SDSU team. Because none of the team members were technical 
experts in the SCWO process, it was difficult to provide any technical input on the survey questionnaire. As a result, only minor changes were suggested that made survey more conducive to a web-based format. The next step was selecting the online survey tool. It was deemed necessary that such a tool should make the survey rollout process relatively simple, with data import/export capabilities built into the service. The name of surveymonkey.com came at the top of the recommended survey tools. The $\$ 19.95 /$ month rate for http://www. surveymonkey.com entitles users to advanced tabulation capabilities and tracking information, which we intended to use. A copy of the service agreement can be found in Appendix E. Charting and table creation is also offered as services under the agreement. After initiating our surveymonkey.com account, we converted the paper survey into an electronic version and designed the visual layout in accordance with General Atomics' preferences.

Although surveymonkey.com offered some customization features, there were limitations to it. For example, we would have liked more customizable attributes for each database entry. However, surveymonkey.com allowed only one custom attribute. As mentioned before, the answers for some questions appeared to be incompatible with previous responses. Adding some "logic" to the tool would have helped to make some answers make more sense. For example, some respondents answered that they had more than ten (10) processing plants in the organization, yet only listed two (2) primary- and five (5) primary-and-secondary treatment plants (which doesn't add to ten!) in the following question.

The web survey was tested several times by sending the web link to known respondents and having them take the survey. Results were collected and tested in real time. The valuable feedback from the respondents was incorporated into the survey. This practice helped the SDSU team to perfect the survey rollout procedure and enhance the confidence in the survey tool.

Parallel to this effort, we created a database of contacts. These contacts were determined through extensive Internet searches. Since we were a team of four people, we divided the fifty United States and ten Canadian provinces into four lists and distributed it amongst the team in order to avoid overlap. Then began the lengthy process of carrying out in-depth Internet searches in order to gather e-mail addresses for the Director of 
Public Works for the municipalities of various cities and counties that operate wastewater treatment plants. Each team member had a target of 250 e-mail addresses in mind and care was taken to cover as much geographical area as possible while collecting the information. We took care to collect the phone numbers in addition to e-mail addresses so that the person could be reached via phone if the response rate did not meet our expectations. The team agreed in advance on the exact format of all the contact data collected by each team member so that it would later be easy to upload it into the surveymonkey.com database.

Throughout this effort, several key steps were taken to increase the response rate for this survey. We made our best effort to identify the specific e-mail address of the Public Works Director for municipalities nationwide, rather than a general contact e-mail address. We were successful in compiling a database of 967 contacts across the United States and parts of Canada. Another step taken to increase response rate was addressing the e-mails sent to potential respondents from an SDSU student account, appealing to the academic nature of the situation. Professor Sciglimpaglia allowed us to use his name and contact information in the e-mail for respondents wishing to verify the authenticity of the study. It was also decided to offer incentive to fill out survey, specifically, feedback on the survey results to participating respondents. Finally, utmost attention was given in the web survey design to ensure that the survey would not take more than twenty to twentyfive minutes. A copy of this finalized questionnaire can be found in Appendix $C$.

Logistics of rolling out the survey involved various alternatives and the following is a description of the eventual rollout. First, an introductory e-mail was sent out to each e-mail address in the database; a copy may be found in Appendix B. This e-mail described the nature of the project, invited them to participate in the survey and provided a web address for their prompt participation. We experienced a strong initial response, in fact, 30 of our contacts responded within 24 hours and 61 within 48 hours. This first batch e-mail also resulted in the return of many e-mails, indicating invalid e-mail addresses. An e-mail reminder followed the initial e-mail by approximately two weeks. This e-mail can be found in Appendix B. Although we had selected a relatively uniform sample throughout the USA, an even geographical distribution of the respondents could 
not be guaranteed since this was an e-mail based survey. This limitation appears to be relatively insignificant, though, in light of our mapped data points. The large number of quality contacts that we did collect may have mitigated the possible downside, as well.

Upon surpassing our target of 100 respondents, we ended the survey on July 27 , 2002 with 121 survey participants. Of our total survey recipients of 983 (967 Initial +16 Secondary), the 121 survey participants represent a response rate of $12.3 \%$. This is an order of a magnitude larger than the 1-2\% response rate for a typical email survey. We then began the data reduction and analysis portion of the study. The raw data and tables provided by surveymonkey.com were exported from their Internet location into an Excel file on a team member's local system. A copy of the raw data that was collected has been sent to Carol Smith. Some of these data were then reduced and altered so that responses to open-ended questions were in a similar format. Initially, each question was considered independently of the others and an appropriate table or chart was created in order to visualize these results. In several cases, input was required from General Atomics in order to determine appropriate data ranges. Upon completion of the individual question analysis, we then considered the two "deal-breaking" questions in the context of other questions and determined the appropriate cross-tabulated tables that should be created. The critical questions asked if the respondent was considering new disposal methods and if he/she had an interest in SCWO. Specifically, we cross-tabulated the results for these questions with questions from each of the survey's three general sections. These tables were created by utilizing both the "Auto Filter" and the "Summary Statistics" functions within Excel and can be found in the results section. The questions mentioned above clearly indicate interest in new or different sludge disposal methods and interest or potential use for SCWO, respectively. The analysis of these two questions against the remaining questions revealed a general profile for the types of municipalities that are interested in new biosolids disposal methods, SCWO technology, or both. This table is presented and discussed in the Conclusions section of this report.

Mapping of respondents was a difficult task. Responses were automatically labeled by surveymonkey.com with the respondents' computer IP addresses. Marking 
IDs in this manner helped the team protect the integrity of the data, preventing duplication of answers or forgery of information. These numerical addresses were broken down into components and matched to corresponding latitude and longitude points. The points were then simply (but painstakingly manually) mapped on the chart that appears in the results section that follows. We believe that this information visually gives a good insight into concentrations of interested parties (those who took the time to fill out the survey) and elucidates the range of areas that the student team blanketed. Copies of the maps can be found in Appendix A.

The final step of the team's method was to report back to respondents and deliver on our promise of feedback. A copy of our final contact letter is found in Appendix B. Included in the final contact was a brief note of appreciation for the contribution, an edited matrix of the data (to protect the user's identities) and a message directing them to a contact at General Atomics if they want any further information. This allows all parties to maintain their ethical obligations, as the student team can keep the integrity of the academic nature of the assignment intact, and still allow for contact between General Atomics and potential clients to be fostered, at the discretion of each municipality's public works director. 


\section{Results}

The results of this study are discussed in two sections. The first section illustrates the results of the individual survey questions in a graphical format. A pie chart has been chosen to represent the data to help convey the greater market picture, and helps show general tendencies. The second section describes the cross-tabulated tables created in order to address areas of interest specific to General Atomics. This cross-tab format helps show more target-specific information.

\section{Section 1 - Individual Question Results}

Wastewater Treatment Facilities (Questions $1.1-1.10$ of the survey)

\section{Question 1.1: How many wastewater treatment plants are in your organization?}

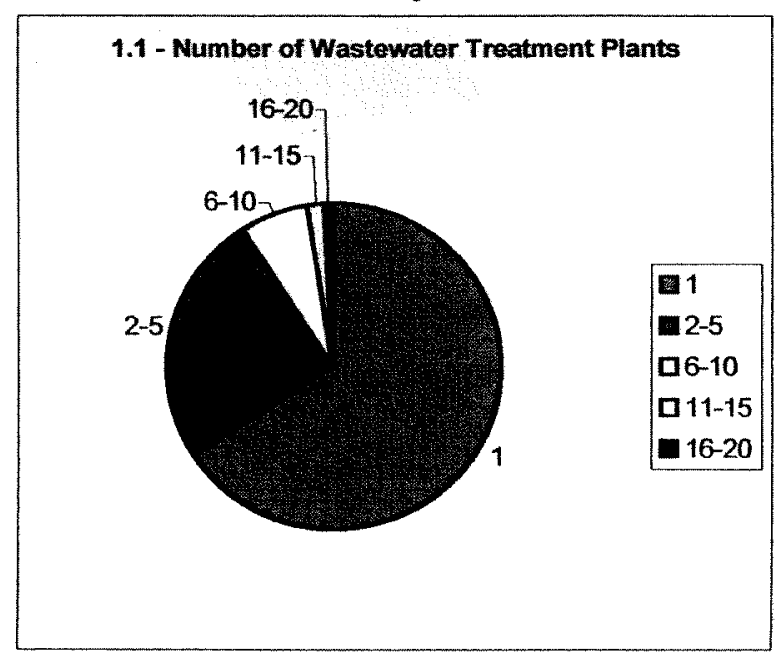

\begin{tabular}{|c|c|c|c|}
\hline \multirow[t]{8}{*}{1.1} & \# of Plants & $\begin{array}{c}\text { Response } \\
\text { Quantity }\end{array}$ & $\begin{array}{l}\text { Response } \\
\text { Percentage }\end{array}$ \\
\hline & 1 & 79 & $66 \%$ \\
\hline & $2-5$ & 30 & $25 \%$ \\
\hline & $6-10$ & 8 & $7 \%$ \\
\hline & $11-15$ & 2 & $2 \%$ \\
\hline & $16-20$ & 1 & $1 \%$ \\
\hline & & 120 & $100 \%$ \\
\hline & Response Rat & $99 \%$ & \\
\hline
\end{tabular}

Respondents indicated that there is typically one wastewater treatment plant per organization, with a $66 \%$ majority. 
Question 1.2a: How many treatment plants are: Primary Onlly?

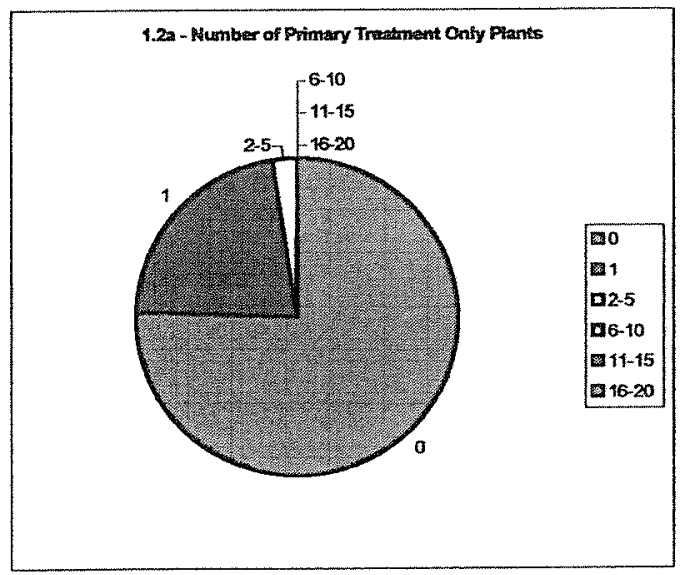

\begin{tabular}{|c|c|c|c|}
\hline \multirow[t]{9}{*}{1.2} & $\begin{array}{l}\text { \# of Primary } \\
\text { Treaiment Plants }\end{array}$ & $\begin{array}{l}\text { Response } \\
\text { Quantity }\end{array}$ & $\begin{array}{l}\text { Response } \\
\text { Percentage }\end{array}$ \\
\hline & 0 & 31 & $76 \%$ \\
\hline & 1 & 9 & $22 \%$ \\
\hline & $2-5$ & 1 & $2 \%$ \\
\hline & $6-10$ & 0 & $0 \%$ \\
\hline & $11-15$ & 0 & $0 \%$ \\
\hline & $16-20$ & 0 & $0 \%$ \\
\hline & & 41 & $100 \%$ \\
\hline & Response Rate & $34 \%$ & \\
\hline
\end{tabular}

Question 1.2b: How many treatment plants are: Primary and Secondary?

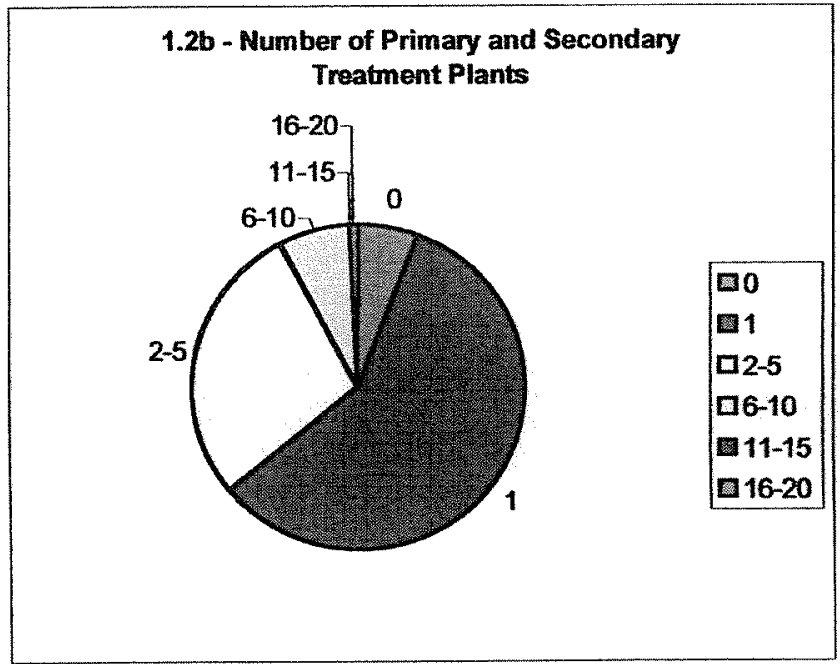

\begin{tabular}{|c|c|c|c|}
\hline \multirow[t]{9}{*}{1.2} & $\begin{array}{l}\text { \# of Primary and } \\
\text { Secondary }\end{array}$ & $\begin{array}{c}\text { Response } \\
\text { Quantity }\end{array}$ & $\begin{array}{l}\text { Response } \\
\text { Percentage }\end{array}$ \\
\hline & 0 & 6 & $6 \%$ \\
\hline & 1 & 60 & $58 \%$ \\
\hline & $2-5$ & 29 & $28 \%$ \\
\hline & $6-10$ & 7 & $7 \%$ \\
\hline & $11-15$ & 0 & $0 \%$ \\
\hline & $16-20$ & 1 & $1 \%$ \\
\hline & & 103 & $100 \%$ \\
\hline & Response Rate & $85 \%$ & \\
\hline
\end{tabular}

This question indicates that there are relatively few "primary treatment only" plants. Of the few that exist, most (90\%) are the only treatment plant in the organization. Also, plants that were both primary and secondary treatment facilities were most likely the only plant in an organization. 
Question 1.3: How old are the existing plants?

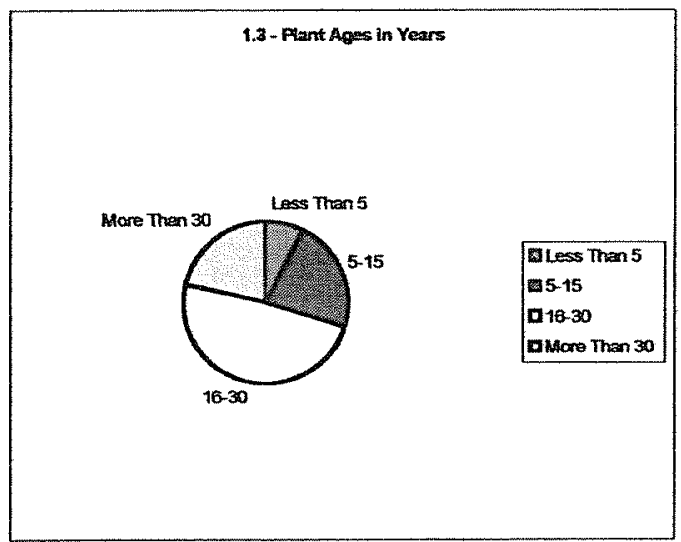

\begin{tabular}{|c|c|c|c|}
\hline \multirow[t]{7}{*}{1.3} & Plant Age & \# of Plants & $\begin{array}{l}\text { Response } \\
\text { Percentage }\end{array}$ \\
\hline & Less Than 5 & 19 & $8 \%$ \\
\hline & $5-15$ & 56 & $22 \%$ \\
\hline & $16-30$ & 124 & $49 \%$ \\
\hline & More Than 30 & 54 & $21 \%$ \\
\hline & & $65-253$ & $100 \%$ \\
\hline & Response Rate & $54 \%$ & \\
\hline
\end{tabular}

This question indicates the general age of equipment currently utilized by the respondents. The results reveal that nearly half of the equipment is between 16 and 30 years old and another $21 \%$ are more than 30 years old.

Question 1.4: What is the population being served?

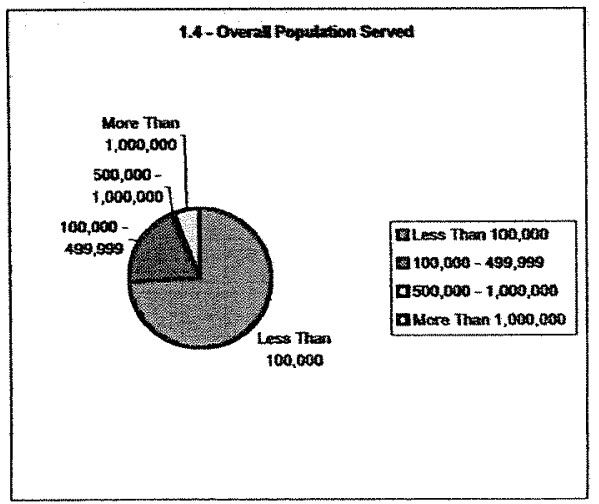

\begin{tabular}{|c|c|c|c|}
\hline 1.4 Population Served & $\begin{array}{c}\text { Response } \\
\text { Quantity }\end{array}$ & $\begin{array}{c}\text { Response } \\
\text { Percentage }\end{array}$ \\
$\qquad$\begin{tabular}{c|c|c|}
\hline $\begin{array}{c}\text { Less Than } \\
100,000\end{array}$ & 78 & $74 \%$ \\
\hline $100,000-499,999$ & 20 & $19 \%$ \\
\hline $\begin{array}{c}500,000- \\
1,000,000\end{array}$ & 1 & $1 \%$ \\
\hline $\begin{array}{c}\text { More Than } \\
1,000,000\end{array}$ & 6 & $6 \%$ \\
\hline & $\begin{array}{c}105 \\
\text { Response Rate }\end{array}$ & $100 \%$ \\
\hline
\end{tabular}
\end{tabular}

Nearly three-quarters of the respondents were serving less than 100,000 . 
Question 1.5: What is the total treatment capacity (gallons per day)? What is the number of separate plants?

\begin{tabular}{|c|c|c|c|}
\hline \multirow[t]{5}{*}{1.5} & $\begin{array}{l}\text { Treatment } \\
\text { Capacity }\end{array}$ & $\begin{array}{l}\text { Gallons per } \\
\text { Day (MiM) }\end{array}$ & \# of Plants \\
\hline & Average & 22.8 MGD & 1.9 \\
\hline & Median & 7.5 & 1 \\
\hline & Range & 0 to 450 & 0 to 16 \\
\hline & $\begin{array}{c}\text { Response } \\
\text { Rate }\end{array}$ & $80 \%$ & \\
\hline
\end{tabular}

The responses to this open-ended question reveal that an average of 22.8 MGD of waste is treated by an average of 1.9 plants per facility.

\section{Question 1.6: What is the total biosolids capacity of all plants?}

\begin{tabular}{|c|c|c|}
\hline \multirow[t]{5}{*}{1.6} & $\begin{array}{l}\text { Biosolids } \\
\text { Capacity }\end{array}$ & $\begin{array}{c}\text { Dry Tons per } \\
\text { Day }\end{array}$ \\
\hline & Average & 118.5 \\
\hline & Median & 5 \\
\hline & Range & 0 to 2000 \\
\hline & $\begin{array}{l}\text { Response } \\
\text { Rate }\end{array}$ & $61 \%$ \\
\hline
\end{tabular}

The responses to this open-ended question reveal an average biosolids capacity of 118.5 dry tons per day.

Question 1.7: What is the planned capacity for the next 5 to 10 years?

\begin{tabular}{|c|c|}
\hline 1.7 & $\begin{array}{c}\text { Planned } \\
\text { Capacity- } \\
\text { Next 5-10 } \\
\text { Years }\end{array}$ \\
& $\begin{array}{c}\text { Dry Tons per } \\
\text { Day }\end{array}$ \\
\hline Average & 107.5 \\
\hline Median & 6.6 \\
\hline Range & 0 to 2000 \\
\hline & $\begin{array}{c}\text { Response } \\
\text { Rate }\end{array}$ \\
\hline
\end{tabular}

The responses to this open-ended question reveal an average biosolids capacity of 107.5 dry tons per day. The decrease in planned capacity is of interest and may indicate an error in the question. 
Question 1.8: What is the plammed capacity for the next 10 to 20 years?

\begin{tabular}{|c|c|}
\hline 1.8 & $\begin{array}{c}\text { Planned } \\
\text { Capacity- } \\
\text { Next 10-20 } \\
\text { Years }\end{array}$ \\
& $\begin{array}{c}\text { Dry Tons per } \\
\text { Day }\end{array}$ \\
\hline Average & 123.86 \\
\hline Median & 6.83 \\
\hline Range & 0 to 2000 \\
\hline & $\begin{array}{c}\text { Response } \\
\text { Rate }\end{array}$ \\
\hline
\end{tabular}

\section{Question 1.9: What are the current residential and commercial sewer rate charges?}

The results to 1.9 can be found in Appendix D. The open-ended nature of the question resulted in responses not suitable for performing statistical calculations.

Question 1.10: How are capital improvement costs financed?

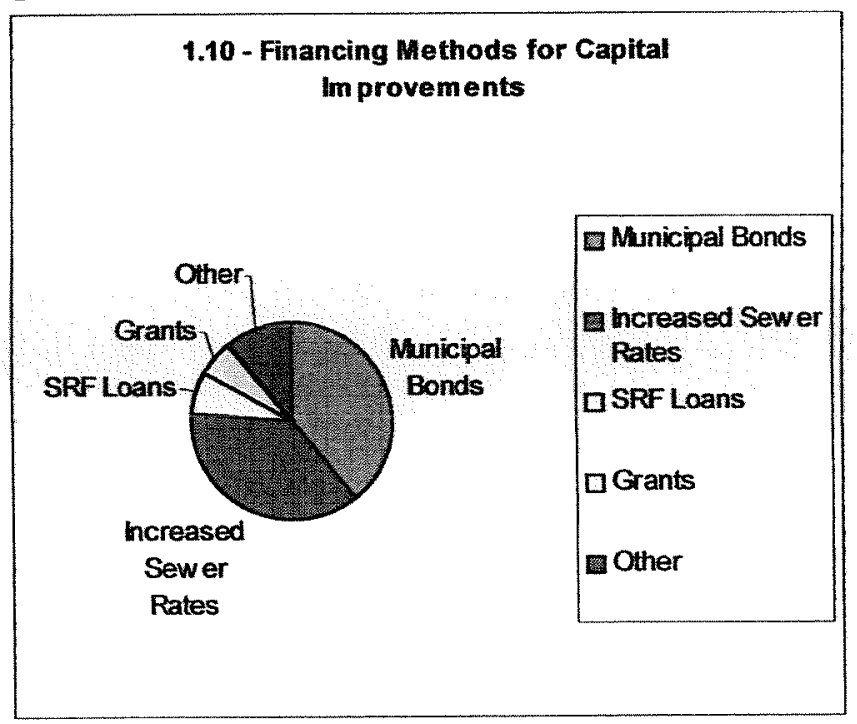

\begin{tabular}{|c|c|c|c|}
\hline 1.10 & Financing Method & $\begin{array}{l}\text { Response } \\
\text { Quantity }\end{array}$ & $\begin{array}{l}\text { Response } \\
\text { Percentage }\end{array}$ \\
\hline & Municipal Bonds & 54 & $66 \%$ \\
\hline & $\begin{array}{l}\text { Increased Sewer } \\
\text { Rates }\end{array}$ & 51 & $62 \%$ \\
\hline & SRF Loans & 10 & $12 \%$ \\
\hline & Grants & 8 & $10 \%$ \\
\hline & Other & 15 & $18 \%$ \\
\hline & & $82 \rightarrow 138$ & $168 \%$ \\
\hline & Response Rate & $68 \%$ & \\
\hline
\end{tabular}

This last question from the first section shows that financing for capital improvements is primarily done through municipal bonds and increased sewer rates, with grants and loans rounding out the other methods. Respondents chose multiple methods in many cases. 138 responses were received from 82 respondents. 
Section 2 - Biosolids Processing (Ouestions 2.1-2.7 of the survey)

Question 2.1: How many treatment plants use the following types of biosolids dewatering?

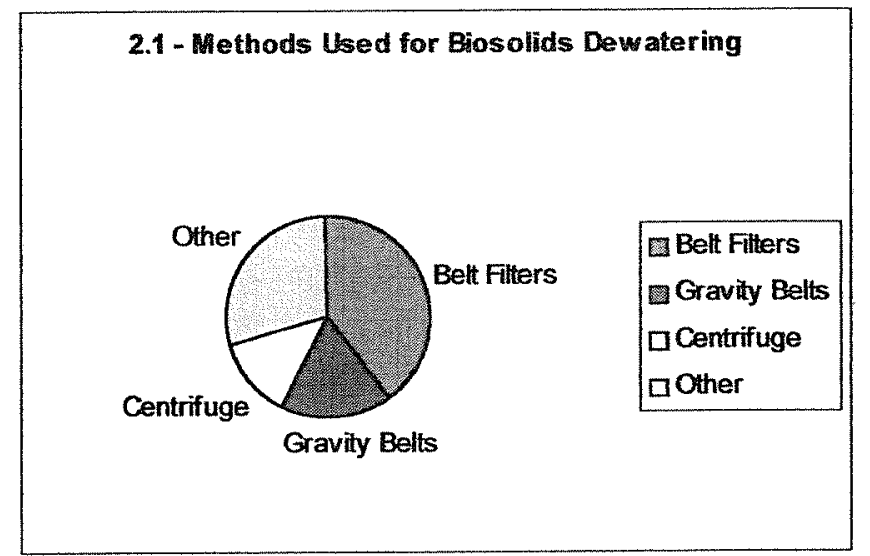

\begin{tabular}{|c|c|c|}
\hline 2.1 & $\begin{array}{c}\text { Dewatering Types } \\
\text { \# of Plants }\end{array}$ & $\begin{array}{c}\text { Response } \\
\text { Percentage }\end{array}$ \\
$\qquad$\begin{tabular}{|c|c|c|}
\hline Belt Filters & 49 & $40 \%$ \\
\hline Gravity Belts & 21 & $17 \%$ \\
\hline Centrifuge & 16 & $13 \%$ \\
\hline Other & 37 & $30 \%$ \\
\hline & $48-123$ & $100 \%$ \\
Response Rate & $40 \%$ \\
\hline
\end{tabular}
\end{tabular}

This question reveals that methods used for biosolids dewatering are primarily belt filters and other methods. Respondents chose multiple methods in many cases. 123 responses were received from 48 respondents.

\section{Question 2.2: What solid levels are currently attained (in \%)?}

\begin{tabular}{|c|c|c|}
\hline \multirow[t]{5}{*}{22} & Solid Levels & $\%$ \\
\hline & Average & 19.43 \\
\hline & Median & 18 \\
\hline & Range & 1.6 to 98 \\
\hline & Response Rat & $63 \%$ \\
\hline
\end{tabular}

The solid level range is very high, but the average level is within expectations. 
Question 2.3: How many operations \& maintenance personnel are assigmed to bioprocessing at each plant?

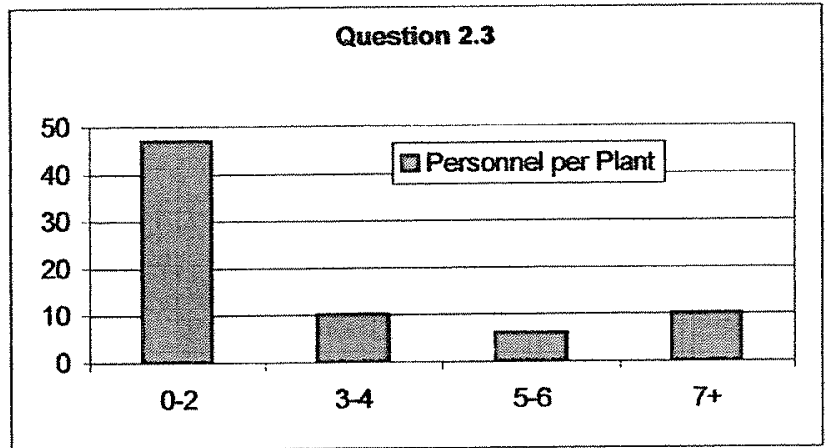

Over 45 of the 73 total respondents have $0-2$ personnel per plant.

Question 2.4: Are plants staffed on a 24/7 basis?

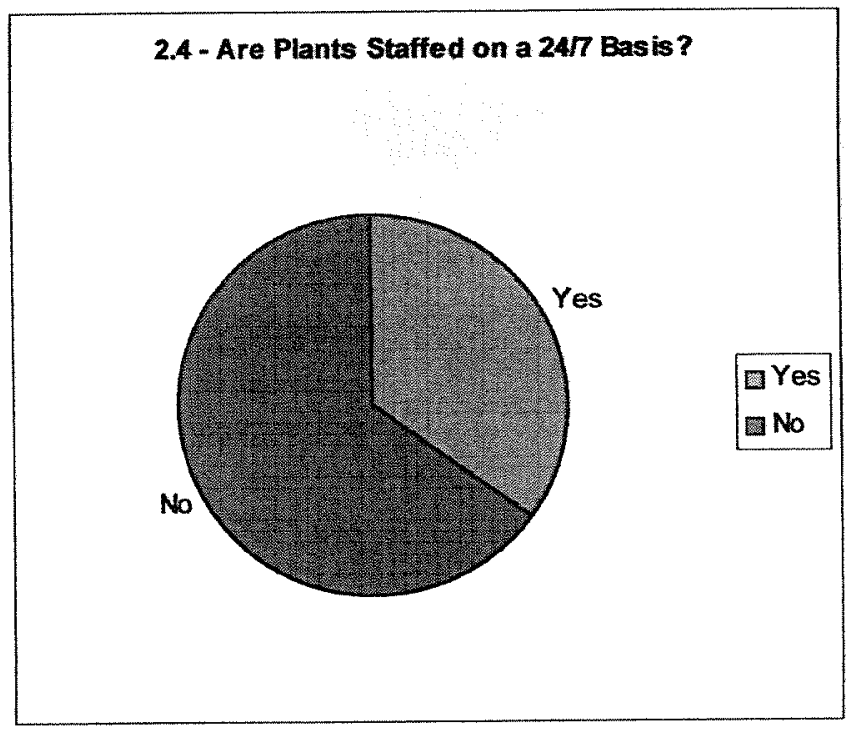

\begin{tabular}{|c|c|c|c|}
\hline \multirow[t]{5}{*}{2.4} & Staffed $24 / 7 ?$ & $\begin{array}{l}\text { Response } \\
\text { Quantity }\end{array}$ & $\begin{array}{l}\text { Response } \\
\text { Percentage }\end{array}$ \\
\hline & Yes & 29 & $35 \%$ \\
\hline & No & 54 & $65 \%$ \\
\hline & & 83 & $100 \%$ \\
\hline & Response Rate & $69 \%$ & \\
\hline
\end{tabular}

The typical plant is not staffed on a round-the-clock basis. 
Question 2.5: How is digester methane used?

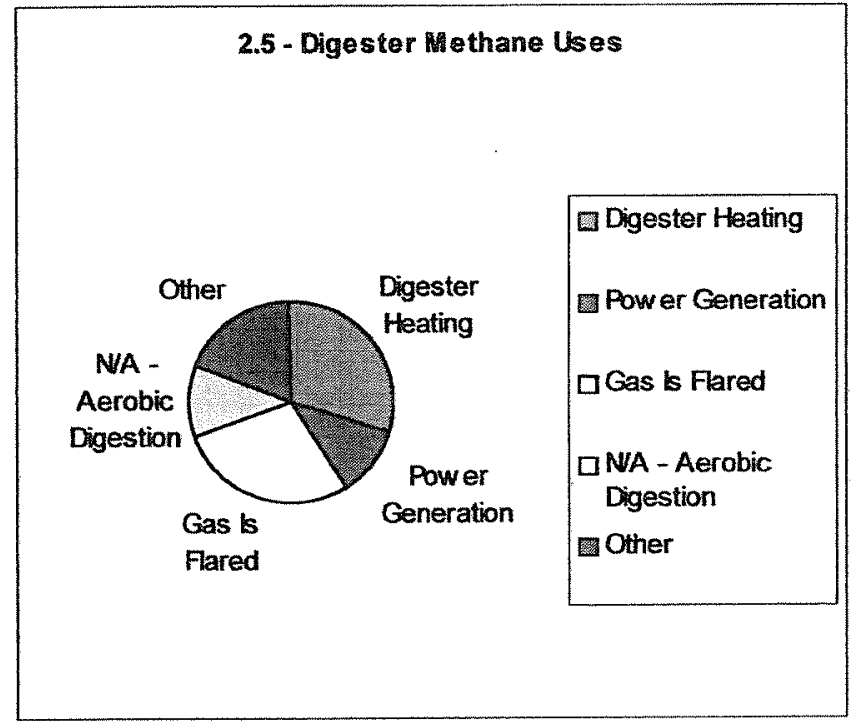

\begin{tabular}{|c|c|c|c|}
\hline \multirow[t]{7}{*}{2.5} & $\begin{array}{c}\text { Digester Methane } \\
\text { Uses }\end{array}$ & $\begin{array}{c}\text { Response } \\
\text { Quantity }\end{array}$ & $\begin{array}{l}\text { Response } \\
\text { Percentage }\end{array}$ \\
\hline & Digester Heating & 36 & $49 \%$ \\
\hline & Power Generation & 13 & $18 \%$ \\
\hline & Gas is Flared & 34 & $47 \%$ \\
\hline & $\begin{array}{l}\text { N/A - Aerobic } \\
\text { Digestion }\end{array}$ & 14 & $19 \%$ \\
\hline & Other & 23 & $32 \%$ \\
\hline & Response Rate & $\begin{array}{c}73 \rightarrow 120 \\
60 \%\end{array}$ & $164 \%$ \\
\hline
\end{tabular}

This question reveals that digester methane is primarily used for digester heating and gas flares. Respondents chose multiple methods in many cases. 120 responses were received from 73 respondents.

Question 2.6: Who operates the methane-powered generators?

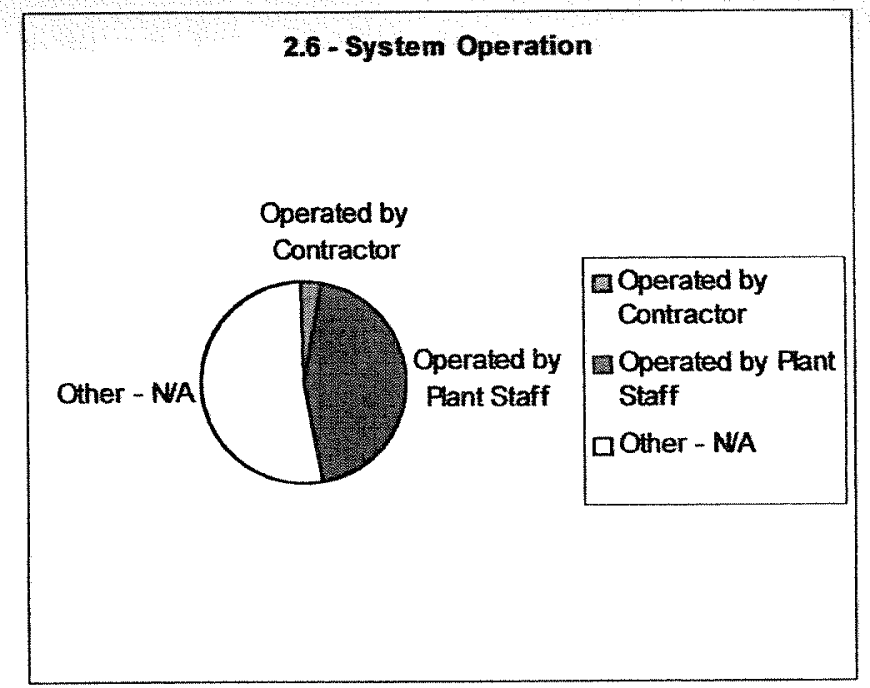

\begin{tabular}{|c|c|c|c|}
\hline \multirow[t]{6}{*}{2.6} & System Operation & $\begin{array}{l}\text { Response } \\
\text { Quantity }\end{array}$ & $\begin{array}{l}\text { Response } \\
\text { Percentage }\end{array}$ \\
\hline & $\begin{array}{l}\text { Operated by } \\
\text { Contractor }\end{array}$ & 1 & $3 \%$ \\
\hline & $\begin{array}{c}\text { Operated by Plant } \\
\text { Staff }\end{array}$ & 15 & $44 \%$ \\
\hline & Other - N/A & 18 & $53 \%$ \\
\hline & & 34 & $100 \%$ \\
\hline & Response Rate & $28 \%$ & \\
\hline
\end{tabular}

In general, it appears that using staff members is more common than the practice of hiring a contractor. It is important to note that $53 \%$ of respondents used a different method or felt that the question did not apply to their operations. 
Question 2.7: Are there near-by industrial neighbors who might be able to use plant steam, power, $\mathrm{CO} 2$ or other products from the wastewater treatment plant?

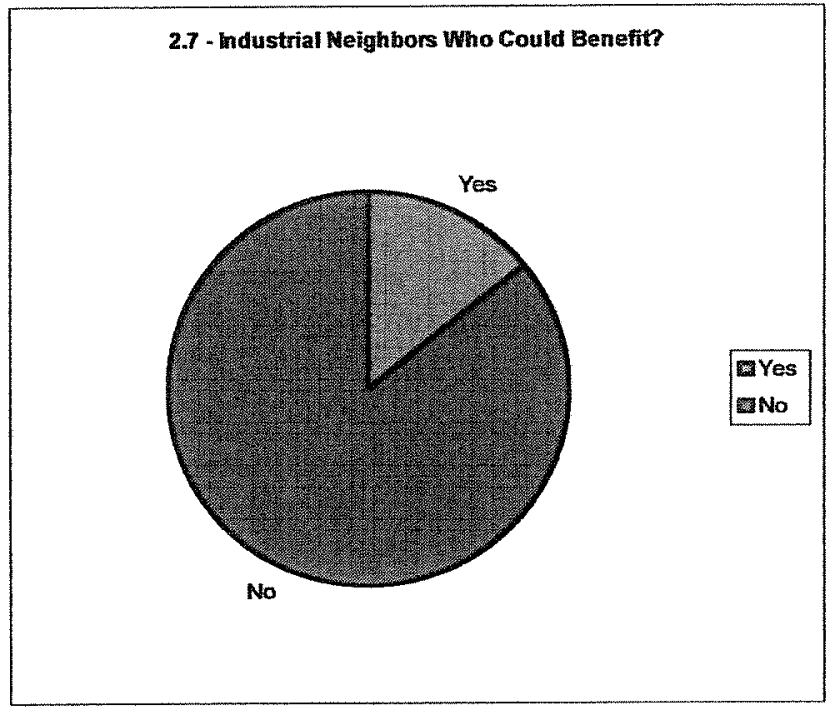

\begin{tabular}{|c|c|c|c|}
\hline \multirow[t]{5}{*}{27} & $\begin{array}{l}\text { Industrial } \\
\text { Neighbors? }\end{array}$ & $\begin{array}{c}\text { Response } \\
\text { Quantity }\end{array}$ & $\begin{array}{l}\text { Response } \\
\text { Percentage }\end{array}$ \\
\hline & Yes & 11 & $14 \%$ \\
\hline & No & 66 & $86 \%$ \\
\hline & & $\pi$ & $100 \%$ \\
\hline & Response Rate & $64 \%$ & \\
\hline
\end{tabular}

In general, respondents do not believe that they have industrial neighbors who can use the byproducts of SCWO.

Biosolids Disposal Process (Questions 3.1-3.9 of the survey)

Question 3.1: How many biosolids disposal facilities does your system have?

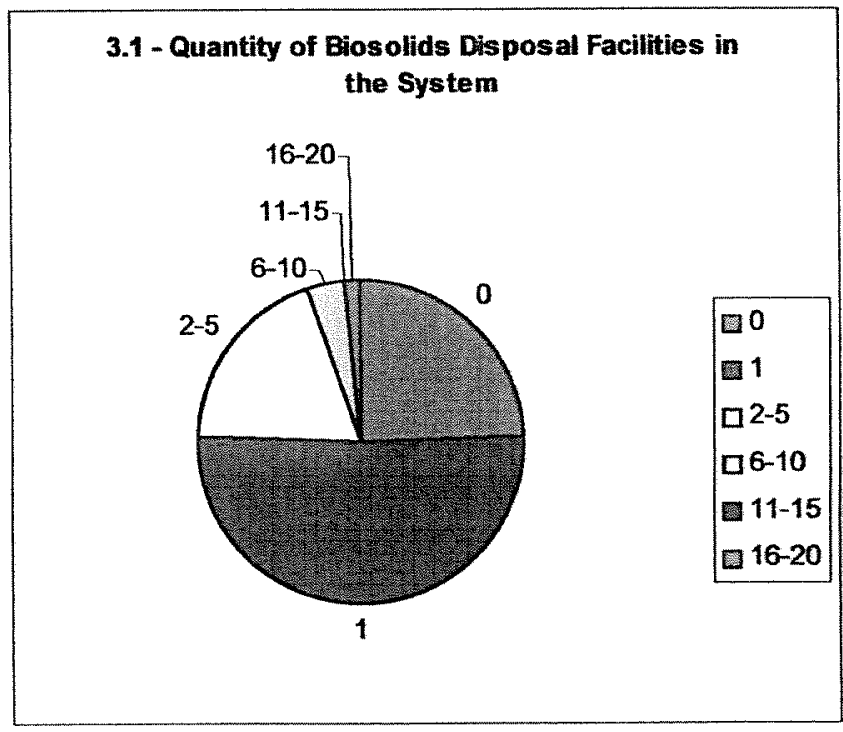

\begin{tabular}{|c|c|c|c|}
\hline \multirow[t]{9}{*}{3.1} & $\begin{array}{l}\text { \# of Disposal } \\
\text { Facilities }\end{array}$ & $\begin{array}{l}\text { Response } \\
\text { Quantity }\end{array}$ & $\begin{array}{l}\text { Response } \\
\text { Percentage }\end{array}$ \\
\hline & 0 & 18 & $24 \%$ \\
\hline & 1 & 38 & $51 \%$ \\
\hline & $2-5$ & 14 & $19 \%$ \\
\hline & $6-10$ & 3 & $4 \%$ \\
\hline & $11-15$ & 0 & $0 \%$ \\
\hline & $16-20$ & 1 & $1 \%$ \\
\hline & & 74 & $100 \%$ \\
\hline & Response Rate & $61 \%$ & \\
\hline
\end{tabular}

$75 \%$ of the respondents have one biosolids disposal facility or less. 
Question 3.2: What is your biosolids disposal method?

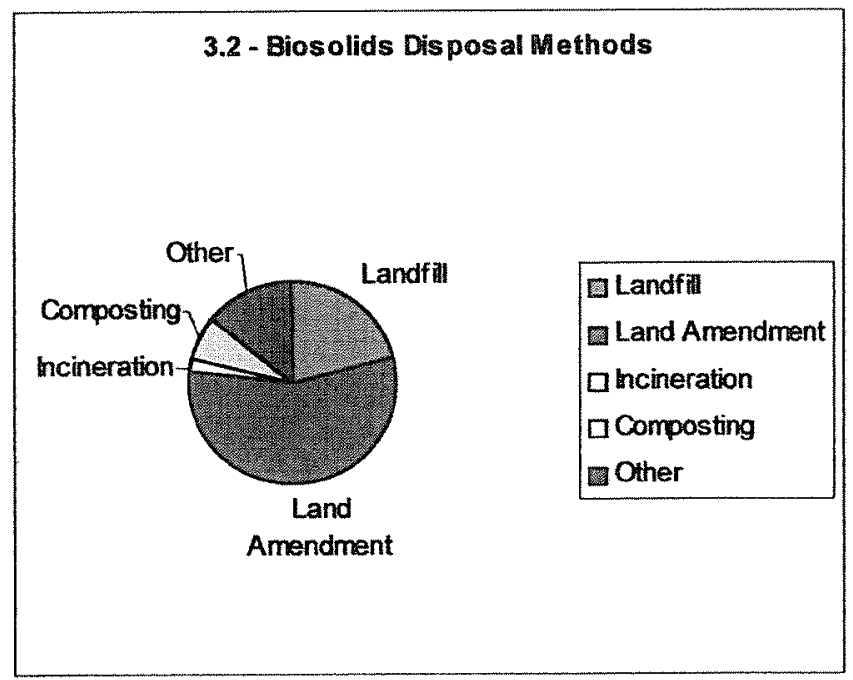

\begin{tabular}{|c|c|c|c|}
\hline \multirow[t]{7}{*}{3.2} & Disposal Method & $\begin{array}{c}\text { Response } \\
\text { Quantity }\end{array}$ & $\begin{array}{l}\text { Response } \\
\text { Percentage }\end{array}$ \\
\hline & Landfill & 21 & $28 \%$ \\
\hline & Land Amendment & 54 & $71 \%$ \\
\hline & Incineration & 2 & $3 \%$ \\
\hline & Composting & 7 & $9 \%$ \\
\hline & Other & 14 & $18 \%$ \\
\hline & Response Rate & $\begin{array}{c}76 \rightarrow 98 \\
63 \%\end{array}$ & $129 \%$ \\
\hline
\end{tabular}

This question reveals that land amendment and landfill are the primary biosolids disposal methods. Respondents chose multiple methods in many cases. 98 responses were received from 76 respondents.

\section{Question 3.3: What are your current sludge disposal costs (\$ per dry ton)?}

\begin{tabular}{|c|c|c|}
\hline \multirow[t]{5}{*}{3.3} & $\begin{array}{l}\text { Sludge } \\
\text { Disposat } \\
\text { Costs }\end{array}$ & $\begin{array}{c}\text { \$per Dry } \\
\text { Ton }\end{array}$ \\
\hline & Average & 114.07 \\
\hline & Median & 54 \\
\hline & Range & 0 to 547 \\
\hline & $\begin{array}{c}\text { Response } \\
\text { Rate }\end{array}$ & $54 \%$ \\
\hline
\end{tabular}

The complete results to Question 3.3 can be found in Appendix D. The openended nature of the question resulted in a low number of responses suitable for performing statistical calculations.

\section{Question 3.4: What are the current landfill costs (\$ per dry ton)?}

The results to Question 3.4 can be found in Appendix D. The open-ended nature of the question resulted in responses not suitable for performing statistical calculations. 
Question 3.5: Are new or different sludge disposal methods being considered?

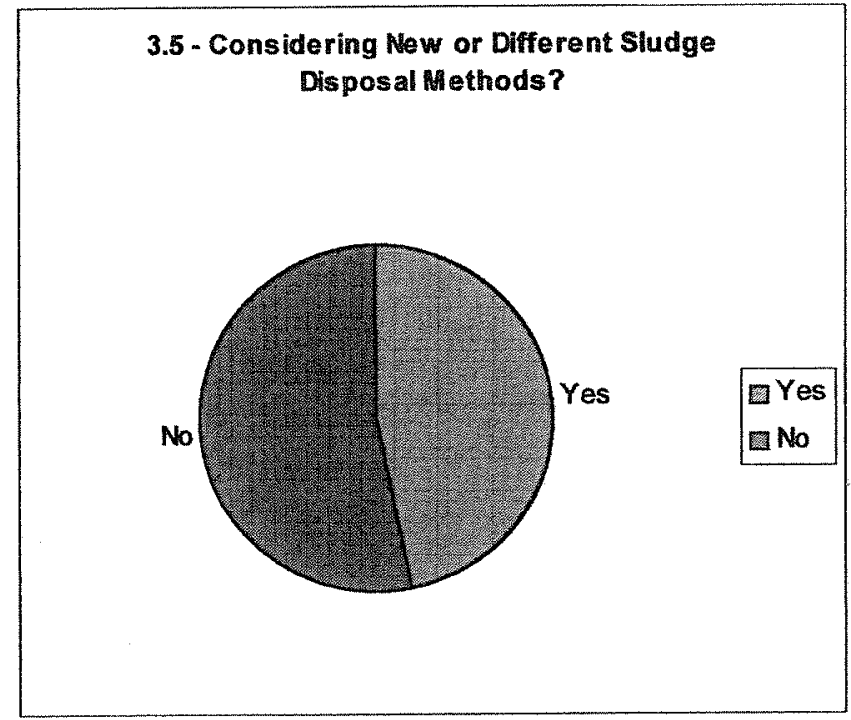

\begin{tabular}{|c|c|c|c|}
\hline \multirow[t]{5}{*}{3.5} & $\begin{array}{l}\text { Considering } \\
\text { Different Disposal } \\
\text { Methods? }\end{array}$ & $\begin{array}{l}\text { Response } \\
\text { Quantity }\end{array}$ & $\begin{array}{l}\text { Response } \\
\text { Percentage }\end{array}$ \\
\hline & Yes & 34 & $47 \%$ \\
\hline & No & 39 & $53 \%$ \\
\hline & & 73 & $100 \%$ \\
\hline & Response Rate & $60 \%$ & \\
\hline
\end{tabular}

Question 3.6: What are the most significant driving forces in your sludge management strategy?

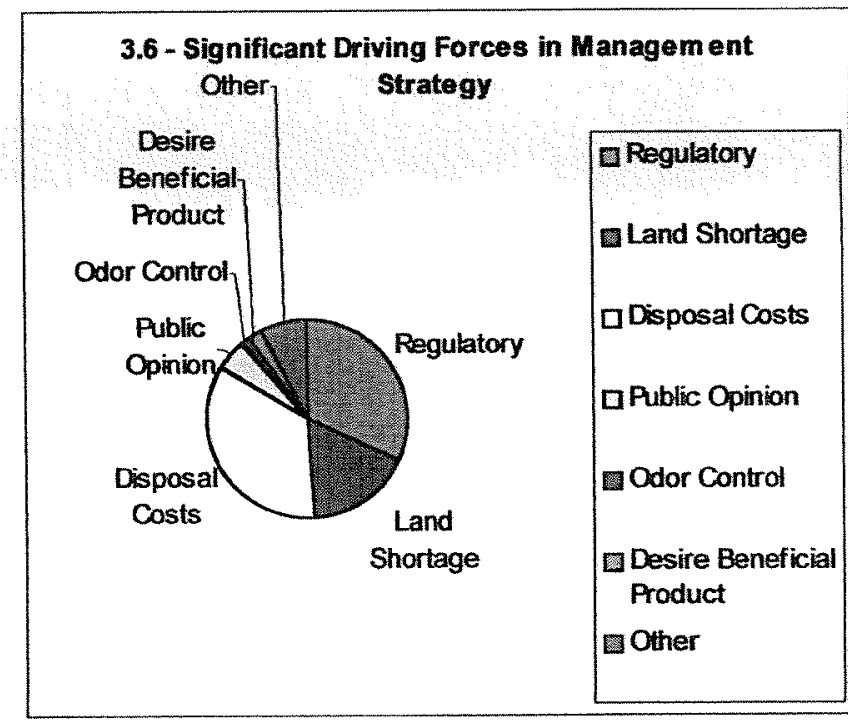

\begin{tabular}{|c|c|c|c|}
\hline \multirow[t]{10}{*}{3.6} & $\begin{array}{l}\text { Strategic Driving } \\
\text { Forces }\end{array}$ & $\begin{array}{l}\text { Response } \\
\text { Quantity }\end{array}$ & $\begin{array}{l}\text { Response } \\
\text { Percentage }\end{array}$ \\
\hline & Regulatory & 40 & $55 \%$ \\
\hline & Land Shortage & 21 & $29 \%$ \\
\hline & Disposal Costs & 44 & $60 \%$ \\
\hline & Public Opinion & 6 & $8 \%$ \\
\hline & Odor Control & 2 & $3 \%$ \\
\hline & $\begin{array}{l}\text { Desire Beneficial } \\
\text { Product }\end{array}$ & 3 & $4 \%$ \\
\hline & Other & 9 & $12 \%$ \\
\hline & & $73 \rightarrow 125$ & $171 \%$ \\
\hline & Response Rate & $60 \%$ & \\
\hline
\end{tabular}

This question reveals that regulatory concerns and disposal costs are the primary driving forces in sludge management strategy. Land shortage is also highly apparent as is the "other" category, which is highly populated with concerns over public perception and acceptance. Respondents chose multiple methods in many cases. 125 responses were received from 73 respondents. 
Question 3.7: If a new sludge disposal method is currently in consideration, what is the estimated capital cost?

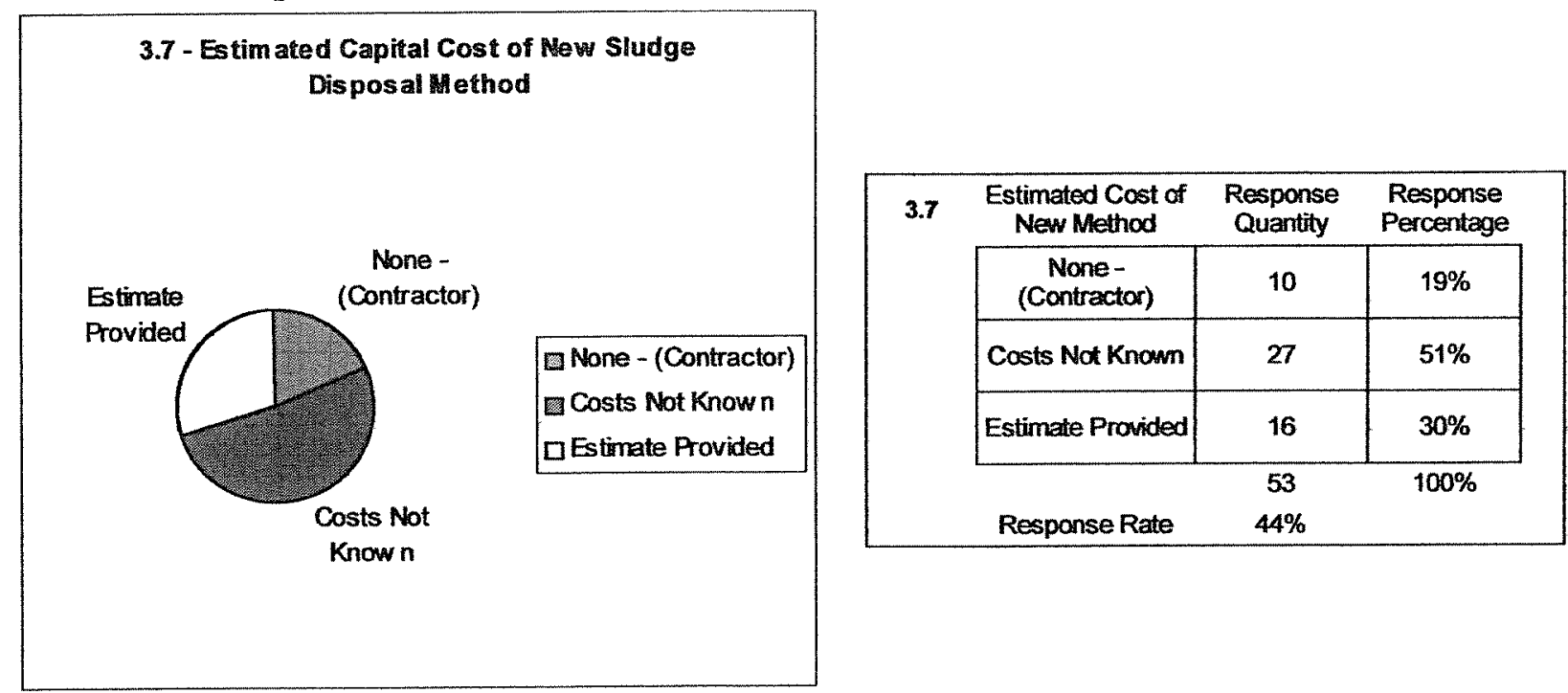

The complete numerical results to Question 3.7 can be found in Appendix D. The open-ended nature of the question resulted in responses to projected costs not being suitable for performing statistical calculations.

Question 3.8: Do you have any interest or potential use for an advanced sludge disposal process called supercritical water oxidation?

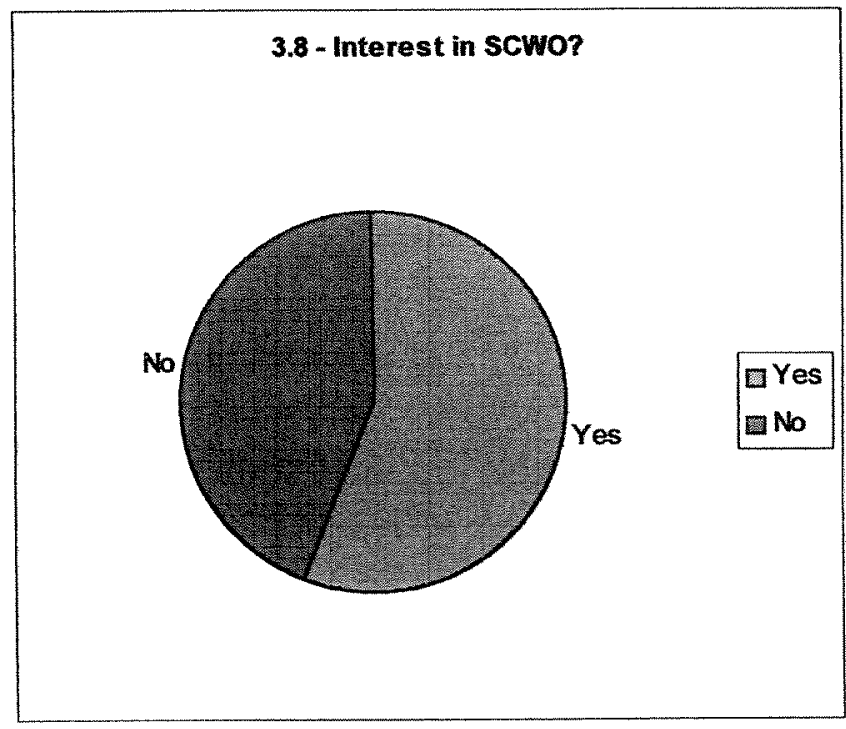

\begin{tabular}{|c|c|c|c|}
\hline \multirow[t]{5}{*}{3.8} & SCWO Interest? & $\begin{array}{c}\text { Response } \\
\text { Quantity }\end{array}$ & $\begin{array}{l}\text { Response } \\
\text { Percentage }\end{array}$ \\
\hline & Yes & 39 & $56 \%$ \\
\hline & No & 31 & $44 \%$ \\
\hline & & 70 & $100 \%$ \\
\hline & Response Rate & $58 \%$ & \\
\hline
\end{tabular}

Just over half of the respondents indicated that they were interested in SCWO. 
Question 3.9: Do you want to receive additional information on this technology?

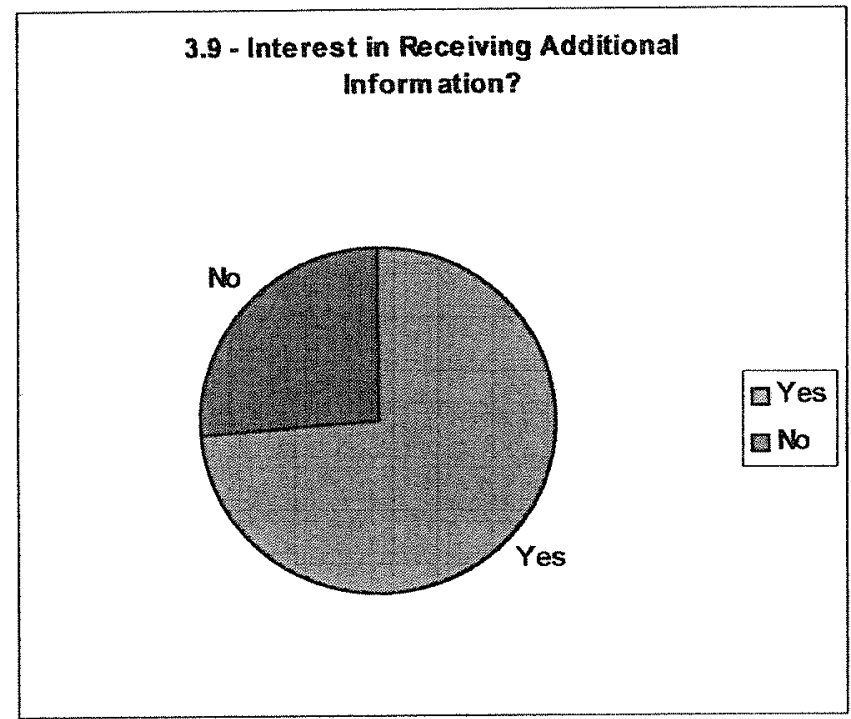

\begin{tabular}{|c|c|c|c|}
\hline \multirow[t]{5}{*}{3.9} & $\begin{array}{c}\text { Desire } \\
\text { Information? }\end{array}$ & $\begin{array}{l}\text { Response } \\
\text { Quantity }\end{array}$ & $\begin{array}{l}\text { Response } \\
\text { Percentage }\end{array}$ \\
\hline & Yes & 53 & $74 \%$ \\
\hline & No & 19 & $26 \%$ \\
\hline & & 72 & $100 \%$ \\
\hline & Response Rate & $60 \%$ & \\
\hline
\end{tabular}

Nearly three-quarters of the respondents wanted more information. 


\section{Section 2 - Cross-Tabulated Results}

The following table examines responses to Questions 1.3 in consideration of Question 3.5. The numbers indicate the average number of plants falling into the age range at the respondent's facility. It is notable that respondents considering new or different disposal methods have more plants over the age of 30 than do those not considering new methods. In comparison to the other age ranges, it can be concluded that facilities with plants older than 30 years are more interested than those with younger plants.

\begin{tabular}{l|c|c|}
\multicolumn{1}{c|}{ Table 1 } & \multicolumn{2}{c|}{ Question 3.5 } \\
\cline { 2 - 3 } \multicolumn{1}{c}{ Question 1.3: How many plants are: } & \multicolumn{2}{c|}{$\begin{array}{c}\text { Are new or different sludge disposal } \\
\text { methods being considered? }\end{array}$} \\
\cline { 2 - 3 } & \multicolumn{2}{c|}{ Yes } \\
\hline Less than 5 years old & 0.8 & 0.8 \\
\hline 5 to 15 years old & 1.0 & 1.2 \\
\hline 16 to 30 years old & 2.2 & 2.4 \\
\hline Older than 30 years & 1.3 & 0.9 \\
\hline
\end{tabular}

The following table examines responses to Questions 1.3 in consideration of Question 3.8. The numbers indicate the average number of plants falling into the age range at the respondent's facility. The table indicates that facilities with younger plants are less likely to be interested in SCWO.

Table 2

\begin{tabular}{|}
\hline \multicolumn{2}{|c|}{ Question 3.8 } \\
\hline $\begin{array}{c}\text { Do you have any interest or potential } \\
\text { use for an advanced sludge disposal } \\
\text { process called supercritical water } \\
\text { oxidation? }\end{array}$ \\
\begin{tabular}{|c|c|}
\hline \multicolumn{2}{|c|}{ Yes } \\
\hline 0.6 & No \\
\hline 0.9 & 1.0 \\
\hline 2.1 & 1.6 \\
\hline 1.2 & 2.7 \\
\hline
\end{tabular}
\end{tabular}


The following table examines responses to Questions 1.4 in consideration of Question 3.5. The numbers indicate the number of respondents serving populations in the range provided. It is notable that larger populations are more likely than populations of less than 100,000 to be considering new or different sludge disposal methods.

Table 3

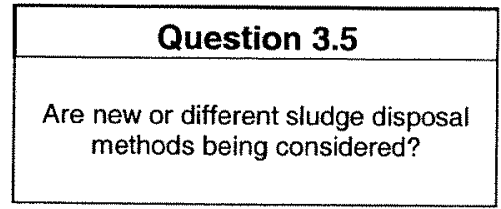

Question 1.4: What is the overall population served:

\begin{tabular}{|c|c|}
\hline Yes & No \\
\hline 23 & 35 \\
\hline 9 & 3 \\
\hline 0 & 0 \\
\hline 2 & 1 \\
\hline
\end{tabular}

The following table examines responses to Questions 1.4 in consideration of Question 3.8. The numbers indicate the number of respondents serving populations in the range provided. It is notable that larger populations are more likely than populations of less than 100,000 to be interested in SCWO.

Table 4

\begin{tabular}{|c|}
\hline Question 3.8 \\
\hline $\begin{array}{c}\text { Do you have any interest or potential } \\
\text { use for an advanced sludge disposal } \\
\text { process called suppercitical water } \\
\text { oxidation? }\end{array}$ \\
\hline
\end{tabular}

Question 1.4: What is the overall population served:

\begin{tabular}{l|c|c|}
\hline Overall population: Less than 100,000 & 29 & 26 \\
\hline Overall population: 100,000 to 499,999 & 8 & 4 \\
\hline Overall population: 500,000 to $1,000,000$ & 0 & 0 \\
\hline Overall population: More than $1,000,000$ & 2 & 1 \\
\hline
\end{tabular}


The following table examines responses to Questions 1.10 in consideration of Question 3.5. The numbers indicate the number of respondents that finance capital improvements with the method indicated. It is notable that municipalities financing capital improvements through increased sewer rates are less likely to be considering new sludge disposal methods.

\begin{tabular}{l|c|c|}
\multicolumn{1}{c|}{ Table 5 } & \multicolumn{2}{c|}{ Question 3.5 } \\
\cline { 2 - 3 } & \multicolumn{2}{c|}{$\begin{array}{c}\text { Are new or different sludge disposal } \\
\text { methods being considered? }\end{array}$} \\
\cline { 2 - 3 } Question 1.10: How are capital improvement costs financed: & Yes \\
\hline Capital improvement costs financed through: Municipal bonds & 20 & 23 \\
\hline Capital improvement costs financed through: Increased sewer rates & 18 & 26 \\
\hline Capital improvement costs financed through: Other & 15 & 14 \\
\hline
\end{tabular}

The following table examines responses to Questions 1.10 in consideration of Question 3.8. The numbers indicate the number of respondents that finance capital improvements with the method indicated. It is notable that municipalities financing capital improvements through increased sewer rates are more likely to be interested in SCWO. This is unexpected as this same group is less likely to be considering new methods for sludge disposal.

Table 6

\begin{tabular}{l|c|c|}
\multicolumn{1}{c}{ Table 6 } & \multicolumn{2}{c|}{ Question 3.8} \\
\cline { 2 - 3 } & \multicolumn{2}{c|}{$\begin{array}{l}\text { Do you have any interest or potential } \\
\text { use for an advanced sludge disposal } \\
\text { process called supercritical water } \\
\text { oxidation? }\end{array}$} \\
\cline { 2 - 3 } Question 1.10: How are capital improvement costs financed: & Yes & No \\
\hline Capital improvement costs financed through: Municipal bonds & 23 & 20 \\
\hline Capital improvement costs financed through: Increased sewer rates & 26 & 15 \\
\hline Capital improvement costs financed through: Other & 18 & 12 \\
\hline
\end{tabular}


The following table examines responses to Questions 2.5 in consideration of Question 3.5. The number indicates the number of respondents that utilize the digester method indicated. It is notable that respondents utilizing tradition (listed) methods are more interested than those utilizing a different (specified other) response. The full list of responses for question 2.5 can be found in Appendix D.

Table 7

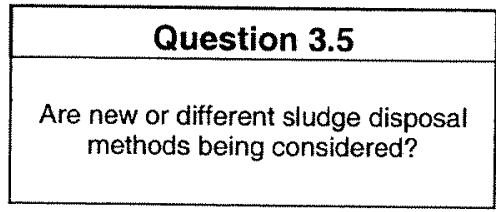

Question 2.5: How is digester methane used:

\begin{tabular}{|l|c|c|}
\hline Use digester methane for Digester Heating & 19 & 14 \\
\hline Use digester methane for Power Generation & 8 & 4 \\
\hline Use digester methane for Flare Gas & 20 & 13 \\
\hline Use digester methane for Other purpose & 6 & 16 \\
\hline
\end{tabular}

The following table examines responses to Questions 2.5 in consideration of Question 3.8. The number indicates the number of respondents that utilize the digester method indicated. It is notable that respondents interest level in SCWO does not appear to correspond to method utilized.

Table 8

\begin{tabular}{|c|}
\hline Question 3.8 \\
\hline $\begin{array}{c}\text { Do you have any interest or potential } \\
\text { use for an advanced sludge disposal } \\
\text { process called supercritical water } \\
\text { oxidation? }\end{array}$ \\
\hline
\end{tabular}

Question 2.5: How is digester methane used:

\begin{tabular}{l|c|c|}
\hline Use digester methane for Digester Heating & 25 & 7 \\
\hline Use digester methane for Power Generation & 10 & 2 \\
\hline Use digester methane for Flare Gas & 25 & 6 \\
\hline Use digester methane for Other purpose & 12 & 8 \\
\hline
\end{tabular}


The following table examines responses to Questions 2.6 in consideration of Question 3.5. The number indicates the respondents that operate their system with contractor, plant staff or other.

Table 9

Question 3.5

Are new or different sludge disposal methods being considered?

Question 2.6: If methane is used for power generation, is the system:

\begin{tabular}{|l|c|c|}
\multicolumn{1}{c|}{ system: } & Yes & No \\
\hline Operated by contractor & 1 & 0 \\
\hline Operated by plant staff & 11 & 4 \\
\hline Operated by Other & N/A & N/A \\
\hline
\end{tabular}

The following table examines responses to Questions 2.6 in consideration of Question 3.8. The number indicates the respondents that operate their system with contractor, plant staff or other.

Table 10

Question 3.8

Do you have any interest or potential use for an advanced sludge disposal process called supercritical water oxidation?

Question 2.6: If methane is used for power generation, is the system:

\begin{tabular}{l|c|c|}
\multicolumn{1}{c|}{ system: } & Yes & No \\
\hline Operated by contractor & 1 & 0 \\
\hline Operated by plant staff & 12 & 4 \\
\hline Operated by Other & N/A & N/A \\
\hline
\end{tabular}


The following table examines responses to Questions 3.2 in consideration of Question 3.5. The number indicates the respondents that utilize the biosolids disposal method listed. A complete list of specified other responses can be found in Appendix D. It is important to note that respondents utilizing land amendment are more likely to be considering new sludge disposal methods.

Table 11

\begin{tabular}{|c|}
\hline Question 3.5 \\
\hline $\begin{array}{c}\text { Are new or different sludge disposal } \\
\text { methods being considered? }\end{array}$ \\
\hline
\end{tabular}

Question 3.2: What is your biosolids disposal method:

Yes No

\begin{tabular}{l|c|c|}
\hline Biosolids disposal method: Landfill & 5 & 10 \\
\hline Biosolids disposal method: Land amendment & 28 & 23 \\
\hline Biosolids disposal method: Incineration & 1 & 1 \\
\hline Biosolids disposal method: Other & 8 & 17 \\
\hline
\end{tabular}

The following table examines responses to Questions 3.2 in consideration of Question 3.8. The number indicates the respondents that utilize the biosolids disposal method listed. A complete list of specified other responses can be found in Appendix D. It is important to note that respondents utilizing land amendment and landfill are more likely to be interested in SCWO.

\section{Table 12}

\begin{tabular}{|c|}
\hline Question 3.8 \\
\hline $\begin{array}{c}\text { Do you have any interest or potential } \\
\text { use for an advanced sludge disposal } \\
\text { process called supercritical water } \\
\text { oxidation? }\end{array}$ \\
\hline
\end{tabular}

Question 3.2: What is your biosolids disposal method:

\begin{tabular}{l|c|c|}
\hline Biosolids disposal method: Landfill & 9 & No \\
\hline Biosolids disposal method: Land amendment & 33 & 14 \\
\hline Biosolids disposal method: Incineration & 0 & 2 \\
\hline Biosolids disposal method: Other & 10 & 16 \\
\hline
\end{tabular}


The following table examines responses to Questions 3.6 in consideration of Question 3.5. The number indicates the respondents that believe the specified driving force is most significant in their sludge management strategy. It is important to note that managers with regulatory and other driving forces are more likely to be considering new sludge disposal methods.

Table 13

\begin{tabular}{|c|}
\hline Question 3.5 \\
\hline Are new or different sludge disposal \\
methods being considered?
\end{tabular}

Question 3.6: Most significant driving forces in sludge management strategy:

\begin{tabular}{l|c|c|}
\multicolumn{1}{c|}{ management strategy: } & Yes & No \\
\hline Regulatory & 23 & 17 \\
\hline Land Shortage & 11 & 9 \\
\hline Disposal Costs & 20 & 23 \\
\hline Other & 11 & 7 \\
\hline
\end{tabular}

The following table examines responses to Questions 3.6 in consideration of Question 3.8. The number indicates the respondents that believe the specified driving force is most significant in their sludge management strategy. It is important to note that managers with land shortage and disposal costs as driving forces are more likely to be considering new sludge disposal methods.

Table 14

\section{Question 3.8}

Do you have any interest or potential use for an advanced sludge disposal process called supercritical water oxidation?

Question 3.6: Most significant driving forces in sludge management strategy:

\begin{tabular}{l|c|c|}
\hline \multicolumn{1}{c|}{ management strategy: } & Yes & No \\
\hline Regulatory & 20 & 18 \\
\hline Land Shortage & 15 & 3 \\
\hline Disposal Costs & 24 & 17 \\
\hline Other & 11 & 8 \\
\hline
\end{tabular}




\section{Conclusions}

The conclusions presented in this section address the items described in the problem statement by characterizing the state of the target market, identifying the driving forces in sludge management strategy, and judging the market potential for introducing SCWO. These key findings will allow General Atomics to further segment their target market and focus future efforts on the municipalities most likely to adopt SCWO.

At the outset of the project, General Atomics identified municipalities with wastewater treatment plants as the potential users of SCWO. Individuals responsible for treatment plants were polled via an online survey and additional insight regarding wastewater facilities was obtained. Specifically, respondents provided details about the composition and age of their facilities. The results from this initial section of the survey revealed that most facilities have less than five wastewater treatment plants in their organization and have been in use for more than 16 years. In fact, $21 \%$ of the plants represented in this survey have been in use for over 30 years. The large percentage of older facilities is a positive finding for General Atomics for two primary reasons. First, the respondents with plants that have been in use for over 30 years indicated that they are currently investigating new technologies to replace these older systems. Table 1 illustrates that facilities considering new or different sludge disposal methods tend to have a larger number of older plants in use. Second, the finding that $70 \%$ of these facilities are at least 16 years of age indicates that the likelihood of marketing SCWO as an upgrade is a feasible possibility.

Another notable result related to SCWO's target market is the indication by survey respondents that increased sewer rates and municipal bonds are often used for financing capital improvements. $76 \%$ of the respondents use one or both of these methods. This finding is an important one as both of these financing methods involve the public either directly or indirectly. Consequently, General Atomics should emphasize the features of SCWO that will be viewed positively by the public, such as the environmentally friendly aspects of the technology. Additionally, survey participants reinforced the assertion that General Atomics should highlight SCWO's politically 
marketable features. $8 \%$ of the respondents manually entered "Public Opinion" as a significant driving force in their sludge management strategy.

By learning about the driving forces in sludge management strategy, General Atomics will be better equipped to address the needs of the customer. The survey results proved to be enlightening in this regard. The Public Works Directors taking part in this survey overwhelmingly identified regulatory issues and disposal costs as their two primary considerations. Land shortage was also considered an important driver in sludge management strategy. This finding is a positive result for General Atomics as the environmentally friendly nature of SCWO technology, its long-term financial benefits, and minimal land usage requirements will be powerful motivators for municipalities interested in upgrading their facilities.

Several criteria were used to evaluate the market potential for introducing SCWO to the wastewater treatment market. Consideration of new or different sludge disposal methods, interest in SCWO technology, and a desire to receive additional information were the primary indicators used to gauge market potential. Optimistic results were obtained in each of these areas. Specifically, $47 \%$ of all respondents indicated that new sludge disposal methods are being considered, while a sizable $73 \%$ of the respondents serving populations of 100,000 or greater are considering new methods. The results indicating interest in SCWO technology is even more encouraging. $56 \%$ of all respondents had interest or potential use for this advanced sludge process and $74 \%$ of the respondents want to receive additional information on this technology. These criteria, and the key findings already discussed, lead us to the conclusion that demand exists for an innovative wastewater treatment technology, and SCWO has the potential to satisfy this demand. 
In addition to addressing the issues outlined in the problem statement, characteristics that were consistent with respondents interested in SCWO or considering new technologies were also identified. These findings will assist General Atomics in further segmenting the wastewater treatment market. According to the survey results, target treatment facilities would ideally have the following characteristics:

- Possess plants that are older than 30 years

- Serve populations of 100,000 to 499,999 and over $1,000,000$

- Use gravity belts or centrifuge for biosolids dewatering

- Utilize greater than 5 personnel at each bioprocessing plant (on average)

- Utilize landfill or land amendment as biosolids disposal method

- Have regulatory concerns and disposal costs as their most significant driving forces in sludge management strategy. 


\section{Recommendations}

The following recommendations are intended to assist General Atomics in addressing the municipal wastewater treatment market.

First, General Atomics should identify target municipalities using the characteristics outlined in the previous section. This will allow General Atomics to focus future efforts on the municipalities most likely to adopt SCWO. The survey respondents that match this description have already been e-mailed and encouraged to contact General Atomics directly for more information regarding SCWO technology.

$>$ Second, General Atomics should begin educating the wastewater treatment market, specifically Public Works Directors, about the benefits of SCWO, particularly with regard to environmental and financial factors. For example, General Atomics should consider setting up a booth to disseminate SCWO brochures and answer questions at the International Public Works Congress \& Exposition. The annual Congress attracts over 5000 public works professionals from both public and private sectors and includes representatives from all across the United States and over 14 international countries.

$>$ Third, General Atomics should use an alternative method for identifying potential customers. The current method, as directed by General Atomics, was to sort respondents based on interest in SCWO or potential use for an advanced sludge disposal process. Unfortunately, survey results showed several respondents listed themselves as "uninterested," even though their responses reveal that they might benefit greatly from SCWO. This finding indicates that a portion of the market could be identified through different sorting criteria. Additionally, interest in the technology could be generated through increased awareness and education.

$>$ Finally, General Atomics should further analyze the raw data collected for this study. The open-ended questions were not ideal for statistical analysis, but did provide additional information and insight that could prove to be useful. 
GA-C24239

APPENDIX A - Maps of Respondents 
121 Survey Respondents from US and Canada

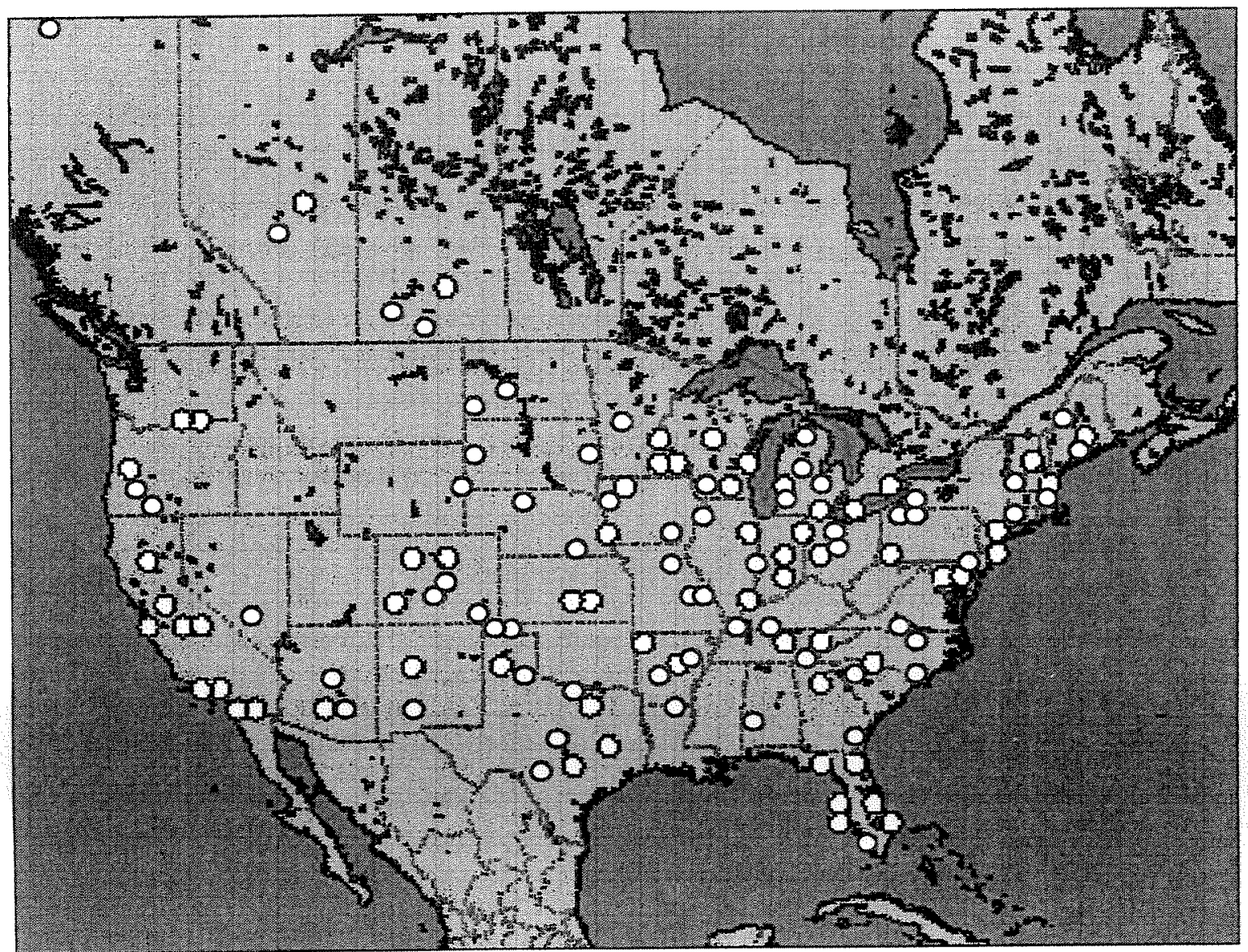




\section{SCWO Interested Respondents}

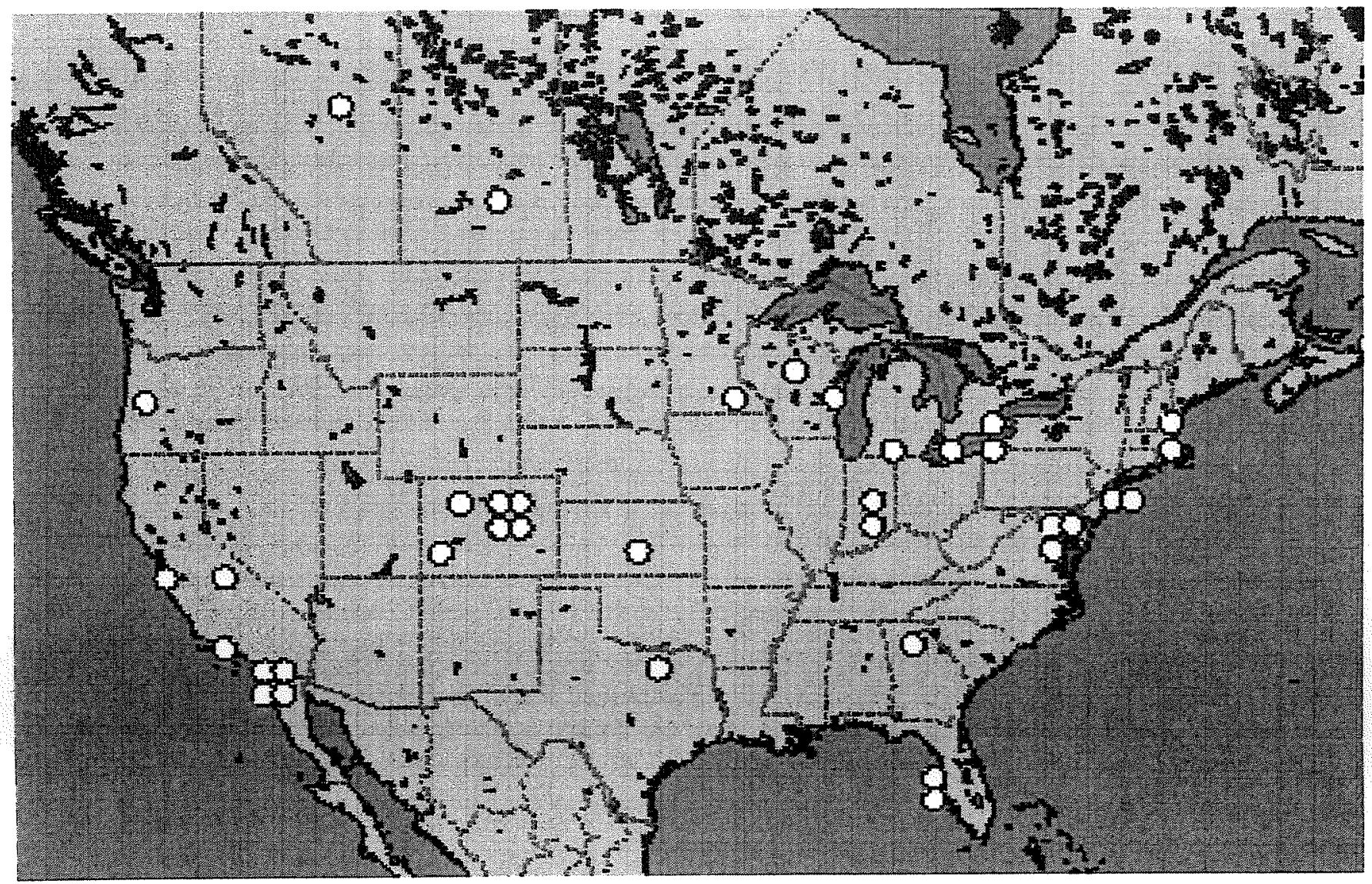


Final 7 Respondents

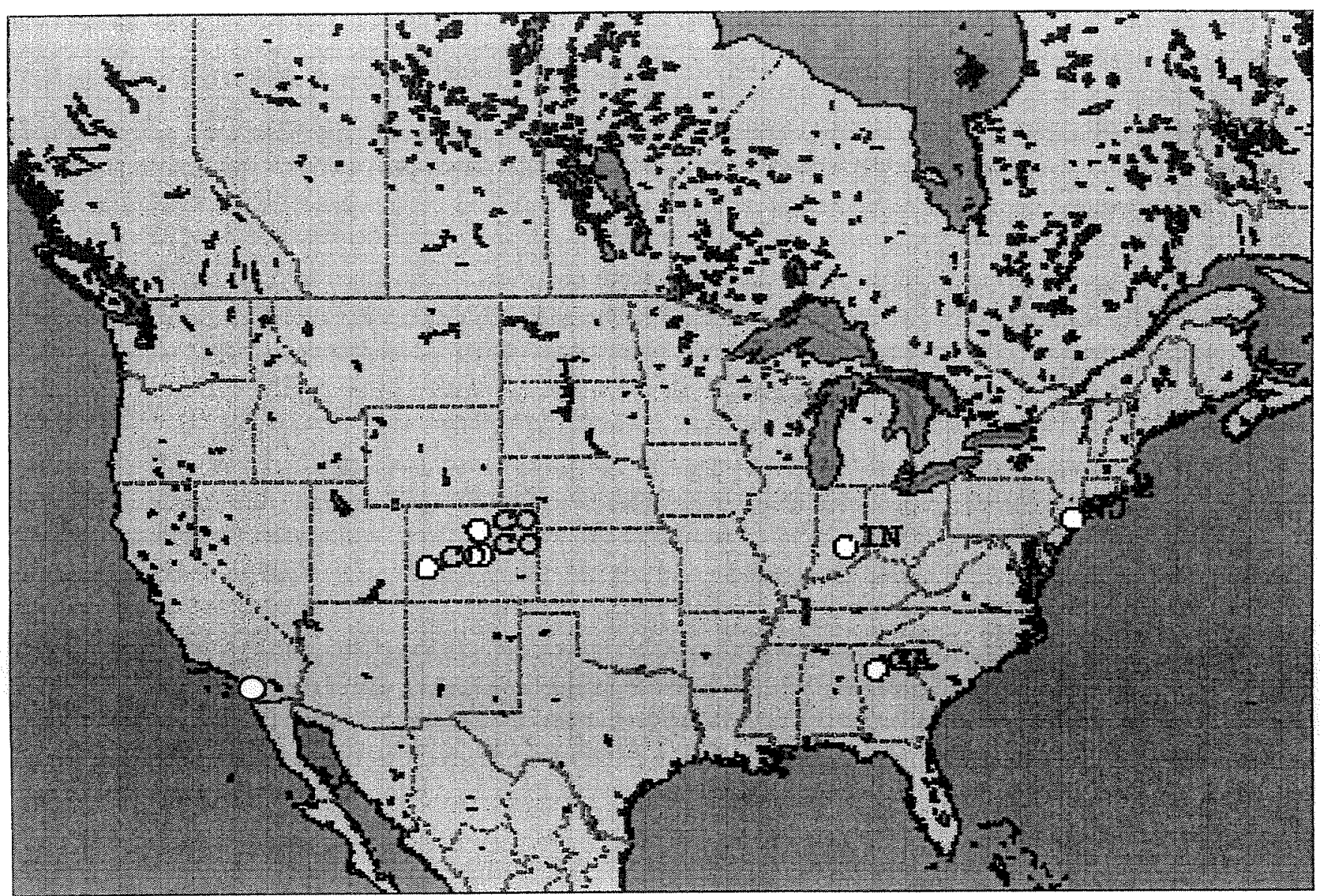


APPENDIX B - E-mail Correspondence 


\section{Dear [Name of the Director of Public Works]}

The San Diego State University Business Alliance requests participation of your organization in a Biosolids Processing and Disposal Survey developed for the purpose of evaluating an alternative technology to current biosolids disposal options.

Biosolids disposal is becoming more difficult every year as new ordinances and laws restrict land placement. Treating biosolids in-house with a new technology called SCWO is an economical and environmentally friendly option. SCWO stands for Supercritical Water Oxidation. Residual solids from SCWO are clean and inert. Energy can be recovered from a SCWO system as steam or hotwater, and other by-products (carbon dioxide, minerals) can be considered for recovery and resale.

This national survey, subsequent analysis, and reporting will comprise the MBA thesis project for a team of graduate students. The results of the survey will be shared with the participating wastewater treatment organizations, giving them valuable nationwide industry data on biosolids processing.

To ensure that the survey results accurately reflect future wastewater management challenges and decisions, we request that the survey be completed by the Municipal Wastewater Department Director (or equivalent) of your organization. If necessary, please forward this message to the appropriate person.

Your participation is very much appreciated. If you have any questions about the survey, please feel free to contact our San Diego State University faculty advisor, Dr Donald Sciglimpaglia at dsciglim@mail.sdsu.edu

A web link to the survey is attached below, please click on the link to launch the survey: http://uww.surveymonkey.com/s.asp?A=1605721E2817

Sincerely,

Business Project Consulting Team

College of Business Administration

San Diego State University 
GA-C24239

D-63 
Dear [Name of the Director of Public Works]

Please accept our kind reminder to participate in the ongoing San Diego State University Biosolids Survey, developed for the purpose of evaluating an alternative technology to current biosolids disposal options.

This national survey, subsequent analysis, and reporting will comprise the MBA thesis project for a team of graduate San Diego State University students. Your organization's participation is a valuable component in our project. The results of the survey will be shared with the participating wastewater treatment organizations, giving them valuable nationwide industry data on biosolids processing.

If necessary, please forward this message to the appropriate (Municipal Wastewater Department Director or equivalent) person, who can help us by filling out the survey.

A web link to the survey is attached below; please click on the link to launch the survey: http://www. surveymonkey.com/s.asp?A=1676754E4941

Sincerely,

Business Project Consulting Team

College of Business Administration

San Diego State University 
To: SCWO Survey Respondent

From : The Student Team at SDSU

Subject: Results of San Diego State University Biosolids Survey

Hello again, and thank you for your assistance in gathering a massive amount of data from across the continent. We were overwhelmed by your responses and appreciate the valuable time you have taken to fill out the requested information.

As promised, you will find an attachment to this letter with our collected data (with sensitive contact data omitted). We hope that you find it as interesting as we did to see current trends in Biosolids Disposal.

This will conclude the series of contacts necessary to complete our project and we would like to again assure you that your anonymity has been protected. If you have any further questions regarding the SCWO technology we have been discussing, please contact the person listed in the information below.

\section{Carol.smith@gat.com}

phone\# (858) 455-2542

Very respectfully,

Business Project Consulting Team College of Business Administration San Diego State University 
APPENDIX C - Biosolids Processing and Disposal Survey 
The San Diego State University Business Alliance greatly appreciates your participation in this Biosolids Processing and Disposal Survey developed for the purpose of evaluating an alternative technology to current biosolids disposal options.

The survey is structured to obtain relevant information in the following three areas of interest:

1) Wastewater facilities information

2) Biosolids processing information

3) Biosolids disposal information

The survey, subsequent analysis, and reporting will comprise the MBA thesis project for a team of SDSU graduate students.

Upon completion of the analysis, the survey results will be shared with you, giving you valuable industry data on biosolids processing.

Click "Next" to get started with the survey.

\subsection{WASTEWATER TREATMENT FACILITIES:}

1.1 How many wastewater treatment plants are in your organization? [ ]

1.2. How many treatment plants are primary treatment only [ ]? primary \& secondary treatment [ ]?

1.3 How many plants are less than 5 years old []$; 5-15$ years old []$; 15-30$ years [ ]; older than 30 years [ ].

1.4 What is the overall population served: [ ] less than 100,$000 ;$ [ ] 100,000 500,000 ; [ ] 500,000-1,000,000; [ ] more than 1,000,000.

1.5 What is the total treatment capacity: [ ] millions gallons per day through a total of [ ] separate plants.

1.6 What is the total biosolids capacity of all plants: [ ] dry tons siudge per day.

1.7 What is the planned capacity next $5-10$ years: [ ] dry tons sludge per day.

1.8 What is the planned capacity next $10-20$ years: [ ] dry tons per day.

1.9 What are the current sewer rate charges: residential [\$] per hundred cubic feet; commercial [\$ ] per hundred cubic feet. 
1.10 How are capital improvement costs financed: [ ] municipal bonds; [ ] increased sewer rates; [ ] other; please specify: [ ].

\subsection{BIOSOLIDS PROCESSING:}

Supercritical water oxidation (SCWO) can be used to destroy biosolids and extract useful heat and other products. The system can take sludge upstream of bio digesters or following; whichever is better for the plant. Upstream is preferred because it eliminates the need for digesters and provides a more useful stream for SCWO.

2.1 How many treatment plants use the following types of biosolids? dewatering [ ] belt filters, [ ] gravity belts, [ ] centrifuge [ ] other, please specify [ ]

2.2 What solids levels are currently attained? (in \%) [ ]

2.3 How many operations \& maintenance personnel are assigned to bio processing at each plant? Plant 1 [ ]; Plant 2 [ ]; Plant 3 [ ]; Plant 4 [ ]; Other plants, please specify [ ]

2.4 Are the plants staffed on a $24 / 7$ basis? [ ] Yes; [ ] No.

2.5 How is digester methane used: [ ] digester heating; [ ] power generation; [ ] gas is flared; [ ] other; please specify: [ ]. .

2.6 If methane is used for power generation, is the system: [ ] contractor operated; [ ] operated by plant staff; [ ] other, please specify: [ ].

2.7 Are there near-by industrial neighbors who might be able to use plant steam, power, $\mathrm{CO} 2$ or other products from the wastewater treatment plant? [ ] yes; [ ] no

\subsection{BIOSOLIDS DISPOSAL PROCESS:}

The simplest way to incorporate supercritical water oxidation into a facility is as an add-on at the end of the process. Instead of burning biosolids or shipping to land amendment or other facilities the bio slurry could be directly processed by SCWO.

3.1 How many biosolids disposal facilities does your system have? [ ].

3.2 What is your biosolids disposal method: [ ] land fill; [ ] land amendment; [ ] incineration; [ ] other, please specify: [ ].

3.3 What are your current sludge disposal costs: [\$ ] per dry ton.

3.4 What are the current landfill costs (based on dry tons)? [ ]

3.5 Are new or different sludge disposal methods being considered: [ ] yes, [] no 
3.6 What are the most significant driving forces in your sludge management strategy? [ ] regulatory; [ ] land shortage; [ ] disposal costs; [ ] other.

3.7 If a new sludge disposal method is currently in consideration, what is the estimated capital cost? [ ] none (disposal by contractor); [\$ ]; not known [ ].

3.8 Do you have any interest or potential use for an advanced sludge disposal process called supercritical water oxidation? [ ] Yes [ ] No.

3.9 Do you want to receive additional information on this technology? [ ] Yes [ ] No

Thank you for completing the survey!!!

Upon completion of the analysis, the survey results will be shared with you, giving you valuable industry data on biosolids processing. The results will help you in your future wastewater management planning needs.

What is your postal zip-code? (This will help us categorize the data) [ ]

Please provide your e-mail address, so that we can send you a copy of the final report. [ ]

Best Regards,

SDSU MBA Project Consulting Team 
GA-C24239

APPENDIX D - Selected Open-Ended Questions 
1.9 What are the current sewer rate charges:

Residential (\$ per hundred cubic feet)

based on water use

$126 \%$ of water declining tier.

$159 \%$

$\$ 7.50$

Rate based on flow Multi tiered rates

0.19 (Canadian)

16

$\$ 1.77$

base rate: $\$ 4.28+\$ 1.347 / 100$ cubic feet

$\$ 2.38$

Cdn\$1.07 (transmission \& treatment only)

$\$ 1.74$

1.45 per 1000 gals

$\$ 2.26$

Operation $\$ 2.24$ Capital $\$ 3.50$

1.65

12.00 per month flat rate

$\$ 10.92+2.15$ / 1k gal. Based on water use up to $12 \mathrm{k}$ gallons.

Flat rate of $\$ 16 /$ Month/Residential Dwelling

$\$ 0.33$

$157 \%$ of Water Bill

$\$ 12.40$ per month

$\$ 3.88$ per 000 gallons

$\$ 22.00 /$ month

$\$ 0.02$

$\$ 420 / 1000$ igals water and sewer

1.29

3.63

0.376

2.28

NA

$\$ 1.47 / 1000$ gals

2

$\$ 2.14 / c c f$

2

0.0216

24.47

0.196

1.74

US $\$ 0.62 / 100$ cu.ft. after $70982 \mathrm{cu} . \mathrm{ft}$. US $\$ 0.23 / 100 \mathrm{cu} . \mathrm{ft}$

$3.66 / 1000$ gals.

flat rate single family - $\$ 21.08$ mobile home $\$ 7.19$ du/triplex 16.17 condo $\$ 8.05$ multiple family res $\$ 11.35$

$\$ 3.90$ per thousand Gallons 
$\$ 3.28+$ Base fee $\$ 9.43$

0.2057

$\$ 6.00$ base $+\$ 1.25 /$ thousand

1.22

0.5

Scale is: 6.70 for 1 st 2000 gal 3.95 for next 8000 gal and 4.80 for next 10000 \& up. NA

$\$ 21.20$ per month flat rate

$\$ 1.88$

$\$ 255.97$ !single family home

1.36

3.21

1.33

NA

1.87

$\$ 18.55$ flat/unit

$2.40 / 1 \mathrm{k}$ gallons

1.21

3.3 What are your current sludge disposal costs (\$ per dry ton)?

approx $\$ 36.00$ (not including labor)

$29.00 /$ wet ton

250

Don't know

\$0. 16399/1 0no gallons

$\$ 60$ (Canadian)

N/A

7.50 (land application costs only)

$\$ 150$

$\mathrm{Cdn} \$ 170$

$\$ 160 /$ ton

150

$\$ 10$ per dry ton

12

120

$\$ 51.61 / \mathrm{CY}$

160

$\$ 54700$ per dry ton

16

0

Land Application - $\$ 20 / d r y$ T;

Composting - \$40/dry $T$ net

$\$ 18.00$

N/A

treatment costs @\$70/ton

$\$ 37.00$ per 000 gallons - centrifuged 
$\$ 210.00$

approx $\$ 120.00 \mathrm{cdn} / \mathrm{ton}$

30

300

650.00 for annual analysis

21

$\$ 108.15$

12.45

$\$ 44.66 / \mathrm{dt}$

175

24

240

$\$ 12$

30

unknown

US\$4.80/ton(US)

$7.00 /$ cubic yard

$\$ 28-\$ 31$

$\$ 21.00$ per ton

$\$ 100.00$

$\$ 250$

275

est $\$ 54 / d r y$ ton

0.002

115

278

$\$ 186$

350

$\$ 200$ (estimate)

$\$ 0.00$ Using on site disposal acerage at this time.

$\$ 300$

neglegable

125

28

$\$ 50$ to $\$ 55$

429

260

$\$ 25.00$

$\$ 193.00$

36

3.4 yothat are the currant

landfill costs (\$ per dry

ton)?

$\$ 25.00$

$40.00 /$ wet ton 


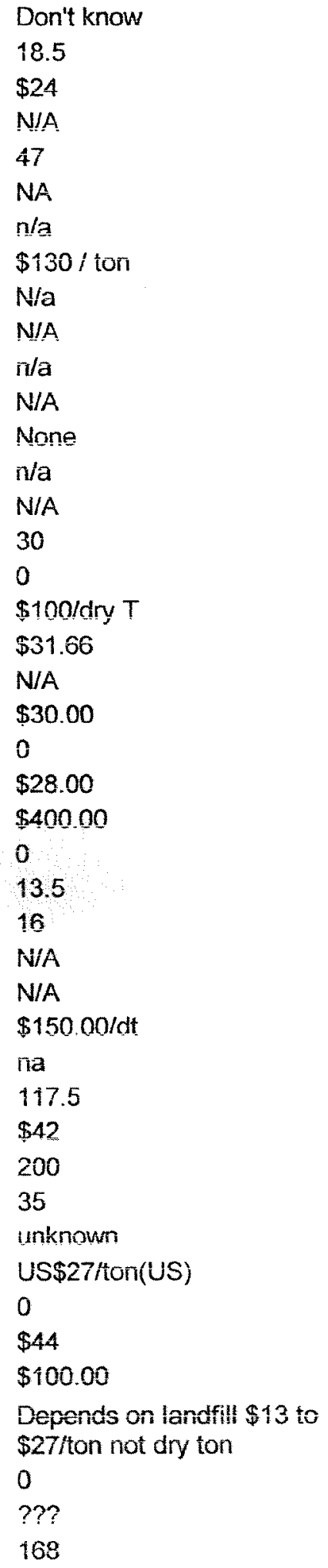




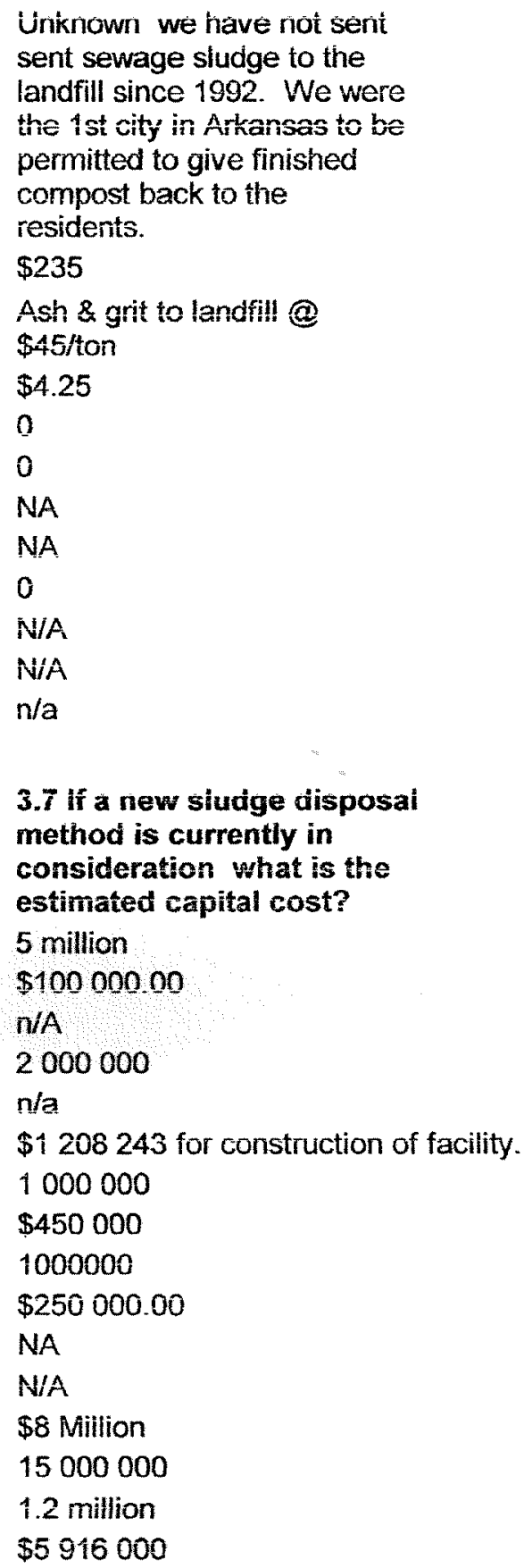


GA-C24239

APPENDIX E - Service Agreement with surveymonkey.com 


\title{
The Best Value Anywhere.
}

SurveyMonkey is both a powerful solution and a tremendous value. Compare our prices to any of our competitors...you'll find that Surveymonkey is tough to match!

\section{Professional Subscription}

A professional subscription is only $\$ 19.95 /$ month, and includes up to 1000 responses per month. If you exceed 1000 survey responses in any given month, there is an additional charge of $\$ 0.05$ per survey response. There are no long-term contracts, and you can cancel at any time. As a professional subscriber, you have access to all of the advanced features of SurveyMonkey. You can create an unlimited number of surveys, with an uniimited number of pages and questions. In addition, all of your surveys are completely unbranded.

\section{Basic Subscription}

\begin{abstract}
A basic subscription is totally free and includes all of the basic features of SurveyMonkey. It's a great option for individuals, students, and anyone who doesn't need the advanced features of SurveyMonkey. Unlike other services, there are no annoying banner ads on your surveys. In addition, all of your survey responses remain absolutely private. Please note that basic subscribers are limited to a total of 10 questions and 100 responses per survey.
\end{abstract}

\section{Compare Us}


The vast majority of our competitors charge much more (sometimes thousands of $\$$ ) for fewer features than SurveyMonkey. In addition, SurveyMonkey was designed from the ground up to be both inviting and intuitive. There are no hidden fees, and no gotchas. Our goal is simple: to create the easiest and most powerful survey tool on the web. We hope you agree. (If you don't agree, feel free to tell us why.) 
APPENDIX F - References 


\section{Referenecs}

Brennan, Pat. "Sewage Treatment on Tap," The Orange Couniy Regisier. Sunday, July 14, 2002. News 1, 25.

Market data reproduced from the report by Dun \& Bradstreet Sales \& Marketing

Solutions provided by http://www.zapdata.com

Market situation information gathered from the following resources:

- http://www apwa.net/ResourceCenter/

- http://www.swana.org

- http://www.wef.org/

- http://www hydroprocessing com 